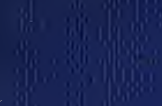









. 



\section{THE ART-REVIVAL IN AUSTRIA}

Edited by Charles Holme

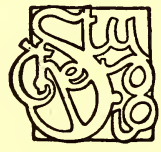

OFFICES OF ،THE STUDIO,' LONDON PARIS, AND NEW YORK MCMVI 
6808

CHM

220710 


\section{PREFATORY NOTE}

REVIVALS in Art spring from a sense of disquietude concerning the existing order of things; they are the strivings after truer and nobler ideals. The efforts made to this end are sometimes encumbered by false issues, but there is never lacking in them some element of right which will be recognised and supported by those who have a keen and real interest in the advancement of human culture.

That there is much of genuine value in the present-day Austrian revival is apparent to all those who take more than a superficial interest in the subject, and some effort has been made in the following pages to select from the various branches of art a few representative examples illustrative of the new movement.

The Editor desires to express his thanks to those artists who have kindly assisted him by allowing their work to be reproduced, and to Herr Hofrat Koch, Herr F. Tempsky, The Miethke Gallery of Fine Arts and The Modern Gallery, Vienna, The Wiener Werkstaette, Messrs. Redlich \& Berger, Messrs. Gilhofer \& Ranschburg, Messrs. Gerlach \& Wiedling, Messrs. Anton Schroll \& Co., and the various firms who have permitted their copyright designs to appear in this volume. 



\section{CONTENTS.}

Section A :

Modern Painting in Austria, by Ludwig Hevesi.-Illustrations after:

Alt, Rudolf von ... … “The Patricians' Club, Innsbruck”-water-colour

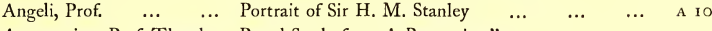

Axentowicz, Prof. Theodor Pastel Study for “A Procession” ... $\quad \ldots \quad$... $\quad$ A I I

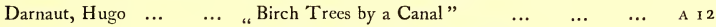

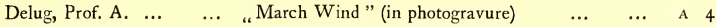

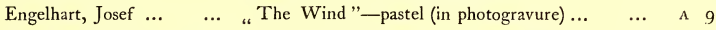

Graf, Ludwig Ferdinand ...

Hampel, Walter ... $\quad \ldots \quad$ “A Quiet Corner ”-Tempera Painting ... $\quad \ldots \quad$ A 15

Horovitz, Leopold _.. Portrait of H.I.M. Franz Josef I., Emperor of

$\begin{array}{lllll}\text { Austria and King of Hungary } & \ldots & \ldots & \text { A } 16\end{array}$

$\begin{array}{ccccccc}\text { " } & \ldots & \text { Portrait of Countess Potocka } & \ldots & \ldots & \ldots \\ \text { Hayek, Hans von } \ldots & \ldots & \text { "Winter by the Riverside " } & \ldots & \ldots & \ldots \\ \text { Jettmar, Rudolf } & \ldots & \ldots & \text {."The Approaching Storm”- } & \ldots & \ldots & \ldots \\ \text { gravure) } & \ldots & \ldots & \ldots & \ldots & \ldots\end{array}$

A 17

A 18

A I

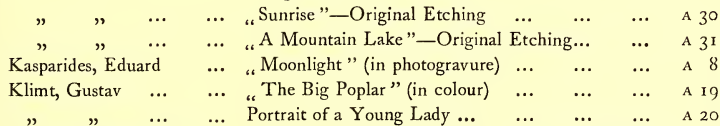

A 30

A 3 I

A 8

Liebenwein, Maximilian ... “The Adoration of the Magi”-Tempera Painting A 2 I " $\quad$... "St. Margaretha "-Tempera Painting $\ldots \quad$... A 22

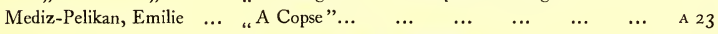

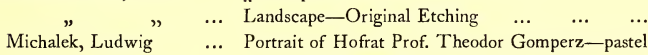

A 38

(in photogravure) $\quad \ldots \quad \ldots \quad \ldots \quad \ldots$

A 2

,,

... Building the Railway Bridge over the Tsonzo, near Salcano-Original Etching $\quad \ldots \quad \ldots \quad \ldots \quad \ldots \quad$ A 32

Moll, C. ... $\quad \ldots \quad \ldots \quad$ “Beethoven's Home in Heiligenstadt” (in photo$\begin{array}{lllllllll}\text { gravure) } & \ldots & \ldots & \ldots & \ldots & \ldots & \text { A } & 3\end{array}$

Müller, Karl $\quad \ldots \quad \ldots \quad$ The Church of the Carmelites $\quad \ldots \quad \ldots \quad \ldots \quad$ A 25

Nowack, Prof. Hans $\quad \ldots \quad$ “The Glazier's Shop, Hall (Tyrol)” (in colour)... A 24

$\begin{array}{llllllllll}\text { Nowak, Anton } & \ldots & \ldots & \text { Znaim (Moravia) } & \ldots & \ldots & \ldots & \ldots & \ldots & \text { A } 26\end{array}$

Orlik, Emil $\quad \ldots \quad \ldots \quad$ “Sunday”-Original Etching $\quad \ldots \quad \ldots \quad \ldots \quad$ A 35

Roux, Oswald $\quad \ldots \quad$... " "Snow Scene"-coloured etching (in colour) $\ldots$ A 34

" $\quad$... ... "A Funeral Procession in Lungau"-Original

$\begin{array}{llllllll}\text { Etching } & \ldots & \ldots & \ldots & \ldots & \text {... } & \text { A } 33\end{array}$

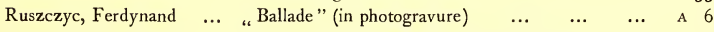

Schmutzer, Ferdinand $\ldots$ Portrait of Josef Joachim-Original Etching $\quad \ldots \quad$ A 36 
Schmutzer, Ferdinand

Stöhr, Ernst

... “The Equestrian "-Original Etching $\quad \ldots \quad$... $\quad$ A 37

Svabinsky, Max ...

$\begin{array}{llllllll}\ldots & \text { "Moonlight" } & \ldots & \ldots & \ldots & \ldots & \ldots\end{array}$

Tichy, Hans

... Portrait of a Lady-wash and pen-and-ink drawing

$\begin{array}{lllllll}\text { (in photogravure) } & \ldots & \ldots & \ldots & \ldots & \text { A } 7\end{array}$

Uprka, Joz̈a $\quad \ldots \quad \ldots \quad$ “A Moravian Wedding” (in colour) $\quad \ldots \quad \ldots \quad$ A 14

\section{Section B :}

Modern Plastic Work in Austria, by Hugo Haberfeld.-Illustrations after:

$\begin{array}{lllllllllllll}\text { Bilek, Frantisek } & \ldots & \ldots & \text { “Moses” } & \ldots & \ldots & \ldots & \ldots & \ldots & \ldots & \text { в } & 8\end{array}$

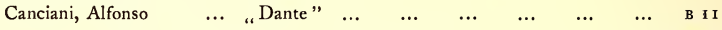

" "

Engelhart, Josef

Gurschner, Gustav

$\begin{array}{lllllllll} & \ldots & \ldots & \ldots & \ldots & \ldots & \ldots & \text { в } 13\end{array}$

Hanak, Anton ...

$\begin{array}{llllllll}\text {... Figure for a Tombstone } & \ldots & \ldots & \ldots & \ldots & \text { B } & 5\end{array}$

$\begin{array}{lllllllllll}\ldots & \ldots & \text { Portrait Study } \quad \ldots & \ldots & \ldots & \ldots & \ldots & \text { в } & 9\end{array}$

Hellmer, Prof. Edmund ... Study for the Goethe Monument in Vienna $\quad \ldots \quad$ в 10

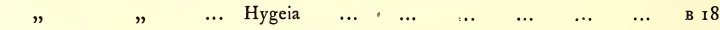

$\begin{array}{lllllllll}\text { Heu, Josef } & \ldots & \ldots & \text { The Artist's Mother } & \ldots & \ldots & \ldots & \ldots & \text { в } 14\end{array}$

$\begin{array}{llllllllllll}\text { Kühnelt, Hugo } & \ldots & \ldots & \text { “Despair” } & \ldots & \ldots & \ldots & \ldots & \ldots & \ldots & \text { в } 7\end{array}$

Luksch, Richard ... ... Reliefs on the façade of the Sanatorium at Pur-

$\begin{array}{lllllllll} & \ldots & \text { Pope Leo XIII. } & \ldots & \ldots & \ldots & \ldots & \ldots & \text { в } 19\end{array}$

$" \quad \quad \quad \quad \ldots \quad$ H.I.M. Franz Josef I., Emperor of Austria and

$" \quad \| \quad \begin{array}{lllllllll}\prime & \ldots & \text { King of Hungary } & \ldots & \ldots & \ldots & \ldots & \text { B } 20\end{array}$

$\begin{array}{llllllllll}" & \quad & \ldots & \text { Ludwig Lobmeyer } \ldots & \ldots & \ldots & \ldots & \ldots & \text { в } 2 \text { I }\end{array}$

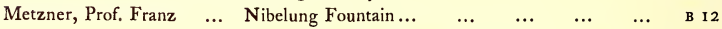

$" \quad, \quad \# \quad \ldots \quad$ Portion of the Stelzhamer Monument at Linz $\quad \ldots \quad$ B 16

Saloun, Ladislav $\ldots \quad \ldots \quad$ Study for the Huss Monument $\quad \ldots \quad \ldots \quad \ldots \quad$ B 15

Seiffert, Franz $\quad \ldots \quad \ldots$ The Strauss and Lanner Mionument in Rath-

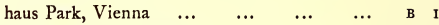

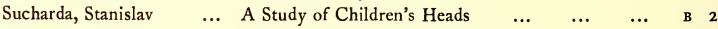

Wollek, Carl ‥ … “Tamino and Pamina "-Portion of the Mozart

Fountain at Vienna $\ldots \quad \ldots \quad \ldots \quad \ldots \quad \ldots \quad$ B 6

\section{Section C :}

The Architectural Revival in Austria, by Hugo Haberfeld. - Illustrations AFTER :

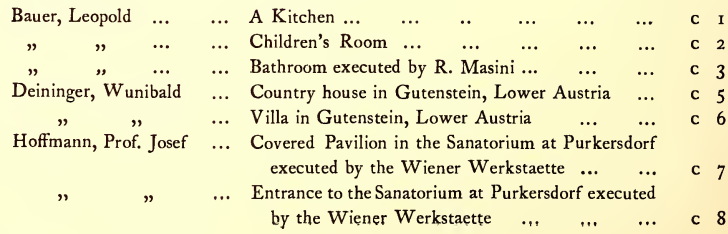


Hoffmann, Prof. Josef

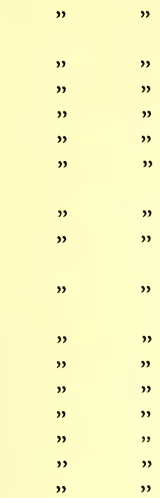

.. Hall of the Sanatorium at Purkersdorf executed by the Wiener Werkstaette

Dining-room of the Sanatorium at Purkersdorf executed by the Wiener Werkstaette ... ..

... Kitchen executed by W. Müller ... $\quad \ldots \quad \ldots \quad$ c... c I I

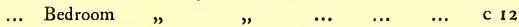

$\begin{array}{llllllll}\ldots & \text { Country House } & \ldots & \ldots & \ldots & \ldots & \ldots & \text { c } 13\end{array}$

... Bent Wood Furniture executed by J. \& J. Kohn

... Room in white enamel and black oak executed by the Wiener Werkstaette

$\begin{array}{llllllll}\ldots & \text { Country House } \quad \ldots & \ldots & \ldots & \ldots & \ldots\end{array}$

... Bedroom Furniture in bent wood executed by $\begin{array}{lllllll}\text { J. \& J. Kohn } & \ldots & \ldots & \ldots & \ldots & \ldots\end{array}$

... Reception-room executed by the Wiener Werkstaette

$\begin{array}{lllllllll}\text {.. Kitchen } & \ldots & \ldots & \ldots & \ldots & \ldots & \ldots & \text { c } 19\end{array}$

... Wardrobe executed by the Wiener Werkstaette...

... Desk and Chair ... ... ...

c 22

c 23

c 24

... Bedroom executed by $W$, Müller... $\quad \ldots \quad \ldots$

... Piano in oak stained black executed by Borsendorfer

... Card Table and Chairs executed by the Wiener $\begin{array}{lllllll}\text { Werkstaette } & \ldots & \ldots & \ldots & \ldots & \ldots & \text { c } 25\end{array}$

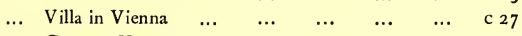

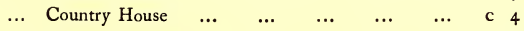

$\begin{array}{llllllllllll}\text { Kotéra, Jan } & \ldots & \ldots & \text { Villa in Bohemia } & \ldots & \ldots & \ldots & \ldots & \ldots & \text { c } 28\end{array}$

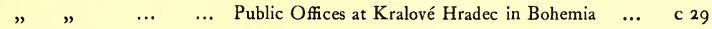

$\begin{array}{llllllllllll} & & \ldots & \ldots & \text { Country House } & \ldots & \ldots & \ldots & \ldots & \ldots & \text { c } 30\end{array}$

Krauss, Baron F... $\quad \ldots \quad$ Design for a Parlour (in colour) $\ldots . \quad \ldots \quad \ldots \quad$ c 26

Moser, Prof. Koloman ... Kitchen Dresser executed by the Wiener Werk$\begin{array}{llllllll}\text { staette } \ldots & \ldots & \ldots & \ldots & \ldots & \ldots & \text { c } 33\end{array}$

... Bedroom in white maple executed by the Wiener $\begin{array}{llllllll}\text { Werkstaette } & \ldots & \ldots & \ldots & \ldots & \ldots & \text { c } 34\end{array}$

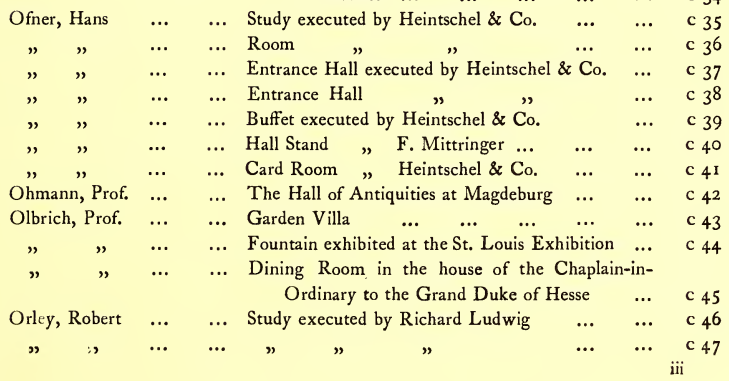


Orley, Robert ...

$\begin{array}{ccc}\text { Prutscher, Otto } & \ldots \\ \text { " } & " & \ldots \\ ", & , & \ldots \\ " & , & \ldots \\ " & " & \ldots \\ " & , & \ldots\end{array}$

$\begin{array}{ccc}\text { Urban, Josef } & \\ " & " & \\ " & & \\ & & \\ " & \quad & \end{array}$

Wagner, Prof. Otto

Witkiewicz, Stanislaw
... Toilet Table in grey beech executed by S. Oppen$\begin{array}{llllllll}\text { heim } & \ldots & \ldots & \ldots & \ldots & \ldots & \ldots\end{array}$

c 48

c 49

c 50

c 51

c 52

c 53

c 54

c 55

c 56

c 57

c 58

of-pearl $\ldots \quad \ldots \quad \ldots \quad \ldots \quad \ldots e \quad \ldots \quad \ldots$

... Boudoir with walls of purple silk and mahogany inlaid with mother-of-pearl, executed by Sandor $\begin{array}{lllllll}\text { Jaray } & \ldots & \ldots & \ldots & \ldots & \ldots & \ldots\end{array}$

Hollmann

... Dining-room executed by Hollmann ... ...

... Sitting-room in Hungarian natural oak executed by Sandor Jaray $\ldots \quad \ldots \quad \ldots \quad \ldots \quad \ldots \quad \ldots$

c 62

... Sitting-room in Hungarian natural oak executed $\begin{array}{lllllll}\text { by Sandor Jaray } & \ldots & \ldots & \ldots & \ldots & \ldots\end{array}$

... Boudoir executed by Sandor Jaray $\quad \ldots \quad \ldots$

... Armchair in oak, inlaid with mother-of-pearl and aluminium, executed by Alex. Albert ... $\quad \ldots$

Country House in Zakopane style, Galicia

\section{Section D :}

Modern Decorative Art in Austria, by A. S. Levetus.-Illustrations after:

$\begin{array}{lllllllll}\text { Andri, Ferdinand } \ldots & \ldots & \text { Book Illustration } & \ldots & \ldots & \ldots & \ldots & \ldots\end{array}$

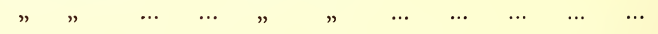

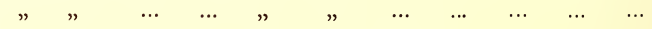

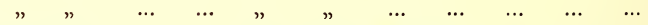

Barwig, Franz $\quad \ldots \quad \ldots \quad$ Woodcarving-Street Figures $\quad \ldots \quad \ldots \quad \ldots$

Böhm, Adolf $\quad \ldots \quad \ldots \quad$ Bookbinding executed by the Wiener Werkstaette...

Czescka, Prof. ... ... Casket in beaten silver presented to H.I.M. Franz Josef I., executed by the Wiener Werkstaette

Dietl, Fritz $\quad \ldots \quad \ldots \quad$ Textile executed by J. Backhausen \& Sons, Vienna (in colour)

Ederer, Carl $\quad \ldots \quad \ldots$ Stained Glass Window executed by Carl Geyling's $\begin{array}{llllllll}\text { Erben } & \ldots & \ldots & \ldots & \ldots & \ldots & \ldots & \text { D } 83\end{array}$

$\begin{array}{lllllllll}\text { Emmel, Bruno } & \ldots & \ldots & \text { Pottery executed by Gebrüder Redlich } & \ldots & \ldots & \text { D } & 2\end{array}$ 
Engelhart, Josef ...

$\begin{array}{llllll}\ldots & \text { Wood Intarsia executed by Kehl ... } & \ldots & \ldots & \text { D } 7 \text { I }\end{array}$

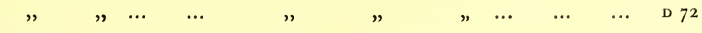

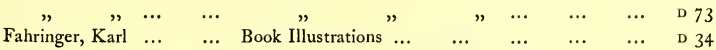

Falke, Baroness $\quad \ldots \quad \ldots \quad$ Tableware executed by Bakalowits \& Sons $\quad \ldots \quad$ D 55

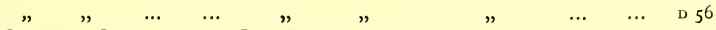

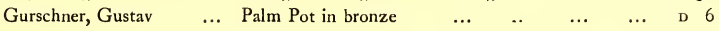

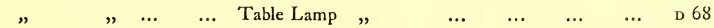

$\begin{array}{llllllllllll} & & \ldots & \ldots & \text { Ash Tray } & & \ldots & \ldots & \ldots & \ldots & \ldots & \mathrm{D} 69\end{array}$

Hoffmann, Prof. Josef $\ldots$ Fruit Stand executed by the Wiener Werkstaette... $\quad$ D 4

" " $\quad$ ". Gold Brooch " " " " $\quad$ D 13

" $"$.. Bookbinding $", \quad " \quad$ D 14

" $\quad$ ". Jewel Box " " " $\quad$ "

" $"$ ". Clock $\quad "$ " $\quad$ "

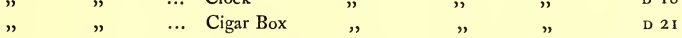

" $\quad$ " $\quad$. Silver Spoon $\quad$ " $\quad$ " $\quad$ " $\quad$ D 57

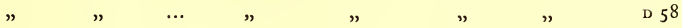

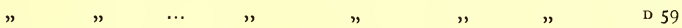

"

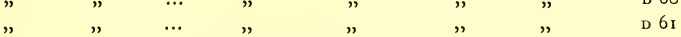

" $\quad$ ".. Beaten Metalwork , $\quad " \quad$ " $\quad$ D 62

",$\quad$..,$\quad$ ",$\quad$ ",$\quad$ D 64

"

" $\quad " \quad \ldots$ Cotton tapestry executed by J. Backhausen \& Sons 0

Hoppe, Emil $\quad \ldots \quad \ldots$ Table lamps and flower stands executed by Baka$\begin{array}{lllllll}\text { lowits } \& \text { Sons } & \ldots & \ldots & \ldots & \ldots & \text { D } 48\end{array}$

Krämer, J. V. ... ‥ “At the Fountain of Bitir"-Illustration from

Lefler, Prof. Heinrich, and “The Sleeping Beauty"-book illustration (in $\begin{array}{llllllllll}\text { Josef } U \text { rban } & \ldots & \ldots & \text { colour }) \ldots & \ldots & \ldots & \ldots & \ldots & \ldots\end{array}$

Lefler, Prof. Heinrich, and "Hänschen, wilt thou Dance?"-book illustration $\begin{array}{llllllllll}\text { Josef Urban } & \ldots & \ldots & \text { (in colour) } & \ldots & \ldots & \ldots & \ldots & \ldots & \text { D } 44\end{array}$

Lenz, Maximilian $\quad \ldots \quad$ Mural Decoration in hammered brass $\quad \ldots \quad$... $\quad$ D 70

$\begin{array}{llllllllllll}\text { Löfler, B.... } & \ldots & \ldots & \text { Ceramic figure } & \ldots & \ldots & \ldots & \ldots & \ldots & \text { D } & \text { I }\end{array}$

Luksch-Makowsky, Elena $\quad$ Panel in beaten brass set with stone $\quad \ldots \quad \ldots \quad$ D I I

" $\quad$ Covers for ventilators in hand-beaten brass $\ldots . .006$

Mehoffer, Prof. Josef von “The Archangel Michael "-Mural Decoration... D 79

" "

"

"

$\begin{array}{cccccc}\text { Messner, Franz } & \ldots & \ldots & \text { Carpet executed by J. Backhausen \& Sons } & \ldots \\ \text { Moser, Prof. Koloman } & \ldots & \text { Fruit Stand "in silver executed by the Wiener } \\ \text { Werkstaette } \ldots & \ldots & \ldots & \ldots & \ldots\end{array}$

"The Archangel Raphael "-Mural Decoration... D 80

“Notre Dame des Victoires"-Design for a $\begin{array}{lllllll}\text { window } & \ldots & \ldots & \ldots & \ldots & \ldots & \text { D } 8 \mathrm{I}\end{array}$

$\begin{array}{lllllll}\text { Design for a window } & \ldots & \ldots & \ldots & \ldots & \text { D } 82\end{array}$

$" \quad$ " $\quad$. Flower Pot in galvanised iron executed by the

D 92

D 93

$\begin{array}{lllllll}\text { Wiener Werkstaette } & . . & \ldots & \ldots & \ldots & \text { D } & 5\end{array}$ 
Moser, Prof. Koloma

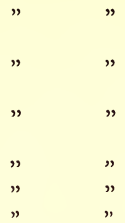

Ofner, Hans

Olbrich, Prof.

Powolny, M.

Prutscher, Otto

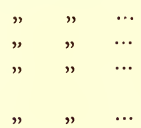

$\begin{array}{lll}", & \cdots & \cdots \\ " & , & \cdots\end{array}$

$\begin{array}{lll}", & " & \ldots \\ " & " & \ldots \\ " & n & \ldots \\ " & n & \ldots\end{array}$

$\begin{array}{lll}n & , & \ldots \\ n & , & \ldots\end{array}$

Schoenthoner, V....

Sika, J. $\quad$... $\quad$...
... Clock in ebony and beaten silver executed by the Wiener Werkstaette ... $\quad \ldots \quad \ldots \quad \ldots$

... Silver Brooch set with stones executed by the Wiener Werkstaette ... $\quad \ldots \quad \ldots \quad \ldots \quad$ D 16

... Bookbinding in morocco executed by the Wiener Werkstaette .................

... Bookbinding in white buck leather executed by the Wiener Werkstaette $\quad \ldots . \quad \ldots \quad$... $\quad$ D 23

... Glassware executed by Bakalowits \& Sons $\quad \ldots \quad$ D 45

$\begin{array}{lllll}\text {... } \quad " \quad \text { " } & \text { D } 47\end{array}$

... Beaten metalwork executed by the Wiener Werk$\begin{array}{llllllll}\text { staette } . . . & \ldots & \ldots & \ldots & \ldots & \ldots & \text { D } 63\end{array}$

... Tray executed by Bakalowits \& Sons $\quad \ldots \quad$... $\quad$ D 10

... Tableware " $" \quad$ " $\quad \ldots \quad$...

... Tapestry in the music-room of the Grand Duke of Hesse

$\begin{array}{lllllll}\text { Ceramic figure } & \cdots & \cdots & \cdots & \cdots & \cdots & \text { D } 84\end{array}$

$\begin{array}{lllllll}\cdots & \cdots & \cdots & \cdots & \cdots & \text { D } & \text { I }\end{array}$

$\begin{array}{llllll}\text {... Hand-painted Bonbonnière } & \ldots & \ldots & \ldots & \text { D } 15\end{array}$

... Cigarette and Card Cases executed by R.Melzer,Jun. D I9

... Jewel Case in rosewood executed by Johann Bauwic D 20

... Blotting Case in seal leather executed by $R$. $\begin{array}{lllllll}\text { Melzer, Jun. ... } & \ldots & \ldots & \ldots & \ldots & \text { D } 25\end{array}$

... Pocket Book in seal leather executed by $\mathrm{R}$. Melzer, Jun. ... $\quad \ldots \quad \ldots \quad \ldots \quad \ldots \quad \ldots \quad$ D 26 Leather Blotting Case executed by B. Buchwald $\quad$ D 29

... Electric Light Pendants executed by Bakalowits \& $\begin{array}{llllllll}\text { Sons } & \ldots & \ldots & \ldots & \ldots & \ldots & \ldots & \text { D } 46\end{array}$ Crystal Flower Bowl executed by Bakalowits \& Sons $\quad$ D 49

... " $", \quad ", \quad$ D 50

... Electric Light Pendant " $\quad$ D 52

... Glass Mosaic executed by Remygius Geyling ... D 76

... Glass Fillings for a sideboard executed by Carl

Geyling's Erben $\quad \ldots \quad \ldots \quad \ldots \quad \ldots \quad$ D 77, 78

... Wool Tapestry executed by J. Backhausen \& Sons $\quad$ D 86

... Textile executed by J. Backhausen \& Sons $\begin{array}{llllllll}\text { (in colour) } & \ldots & \ldots & \ldots & \ldots & \ldots & \text { D } 87\end{array}$

... Textile executed by Carl Giani, Jun. (in colour) D 88

... Hand-Knotted Carpet executed by J. Backhausen \& Sons

$\begin{array}{ccccc}\cdots & \cdots & \cdots & \cdots & \ldots \\ , & n & n & n & \\ , & n & , & & \end{array}$

... Leather Blotting "Case executed by, B. Buckwald... D 28

... Toiletware executed by J. Böch $\ldots \begin{array}{lllll}\ldots & \ldots & \ldots & \text { D } & 8\end{array}$

... Red and White Glass Vases executed by Bakalowits \& Sons

D 9

D 10

D $5^{1}$ 
Section D-Continued.

Sika, J. $\quad \ldots \quad \ldots \quad \ldots \quad$ Electric Light Pendant executed by Bakalowits \&

$\begin{array}{rllllllllll}\text { Sons } & \ldots & \ldots & \ldots & \ldots & \ldots & \ldots & \text { D } 53\end{array}$

Stöhr, Ernst $\quad \ldots \quad \ldots$ Illustration to a Poem. From “Ver Sacrum” ... D $3^{\text {I }}$

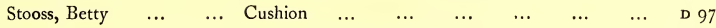

$\begin{array}{lllllllllll} & \| & \ldots & \ldots & \text { Portion of a Table Cover } \ldots & \ldots & \ldots & \ldots & \text { D } 98\end{array}$

$\begin{array}{llllll}\text { Sumetsberger, E. ... } \quad \ldots & \text { Leather Jewel Case executed by B. Buckwald } \ldots & \text { D } 27\end{array}$

$\begin{array}{llllllllll}\text { Taschner, Ign. } & \ldots & \ldots & \text { Book Illustration } & \ldots & \ldots & \ldots & \ldots & \ldots & \text { D } 35\end{array}$

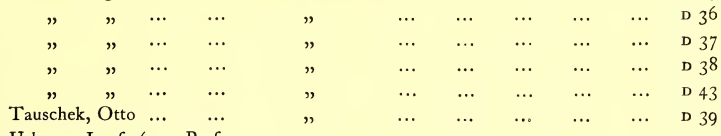

Urban, Josef (see Prof.

Heinrich Lefler,).

Wachsmann, Rosa

Textile executed by S. E. Steiner \& Co. $\quad$... D 90

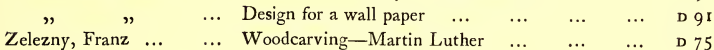

The Copyright of each Illustration in this Volume is reserved by the Owner. 


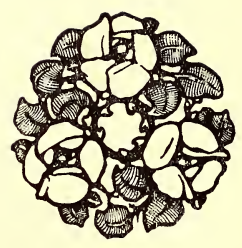




\section{AT RUDOLF JETTMAF}

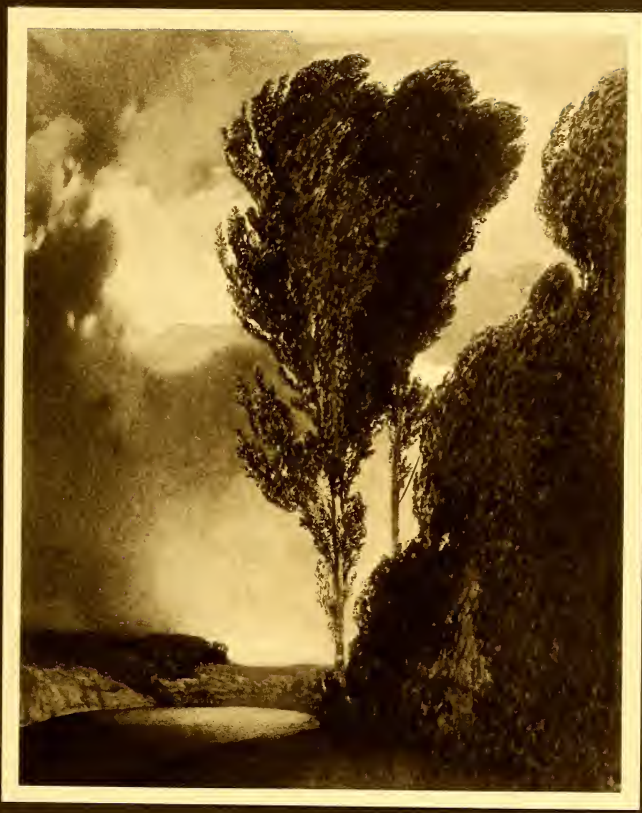

THE APPROACHINC STORM - WATIER-OOLOUR DRAWING IN THE MODERN GALIEAY, VIENNA 



\section{MODERN PAINTING IN AUSTRIA BY LUDWIG HEVESI}

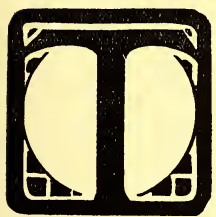

HE Sun of Modern Taste rose in the West. It needed some years to enable its beams to reach the art of Austria, but slowly did light and warmth arrive, amid difficulties which had their natural causes. In matters of art Vienna always inclined to conservatism, for the reason that Flanders and a large part of Italy were for a long time Austrian. The glorious Venetian and Flemish painters of the great days still give their stamp to the Viennese galleries, which are among the richest in the world. Vienna is, inter alia, a Rubens city of the first rank, and it is no wonder that the powerful Austrian painter, Hans Canon (1 829I 885), should have lived and died a student of Rubens in partibus-a sort of posthumous Jordaens. Hans Makart himself (1 840-1884), who inaugurated a period of splendid colour, and intoxicated the whole of central Europe with the hues of his palette, was a new Paolo Veronese, and had a most dazzling effect on the unstrung nerves of a fin de siecle. It was indeed the last brilliant blaze of an old "Gallery art," which was destined to be followed by a new art based on nature. Add to that the baroque traditions of the great Theresian century. Vienna had come down to us as a beautiful baroque city, and in every street there still stand the magnificent palaces and cathedrals, dating from the time of Bernini and Juvara, for this spirit is not to be lightly thrown off. On the other side, the Academy of Fine Arts was a solid fortress of the historical point of view in art and of conventional taste. Its chief teachers of painting were pupils of Rahl, the monumental painter of the city extension (Eisenmenger and Griepenkerl), and its architects were those of the historical style, the "Gothic" Schmidt, the "Greek" Hansen, and the "Cinquecentist" Ferstl; and from this Academy-history-taught and history-teaching-there arose the Society of the "Künstlergenossenschaft," whose members had the lead in the "Künstlerhaus." Simultaneously there existed a leaning towards Parisian colour. August von Pettenkofen (1822-1889) had come into contact with Meissonier and the French painters of the East-Fromentin, Gérôme, Diaz, and others; but he found in Hungary, in the valley of the Tisza, whose praises had already been sung by Lenau, a European Egypt of 1200 geographical square miles, with a lovely little Nile 
and a life as sunny as that of the East. His work was of supreme force in point of light and shade, done in the warm brown tones of the "little masters" of the Netherlands and their Parisian imitators. And at the same time the landscapist, Emil J. Schindler (1842I892), was striking the clear, lyrical notes of the Masters of Fontainebleau. These two artists were free, true spirits, born a little before their time.

Of genuine forerunners of modern painting there was certainly no lack. Of recent years they have been reverently disinterred, and their works, displayed at special exhibitions, have aroused general astonishment. Thus appeared several times the great genre and landscape painter, Ferdinand Georg Waldmüller (1793-1865), who was deposed from his position as Professor at the Academy because he painted in the open air, in full sunlight, - at that time considered far too advanced-and by means of pamphlets strongly urged the reform of the Academy root and branch. Another leader in the revolt-alas! a sadly embarrassed one-was Anton Romako (1832-1889), the memory of whom was revived quite recently by an exhibition. It was the rehabilitation of one scorned in his own time, one who in the struggle for freedom strove to break his bonds. He was the author of the bizarre but thoroughly nerve-inspiring picture, Admiral Tegetboff in the Sea-fight at Lissa. Of the same type, a man of headstrong artistic obstinacy, yet not devoid of discretion, keeping himself well under control, was the landscapist Theodore von Hörmann (1840-1895), the real precursor of the "Secession." $\mathrm{He}$, too, wasted his time in the Künstlerhaus, and then enjoyed a posthumous fame in the "Secession." The auction sale of his property was a great event in Vienna. His favourite motto was "truth." He strove to be absolutely true to nature, and hated everything in the way of studio-made compromise. Indeed, he painted his frost-covered winter scenes seated in the snow, like an Esquimo, thereby catching the cold from which he died. Yet another nature essentially the same, but of a.more delicate fibre, was Rudolf von Alt (1 8 1 2-1905), who only a year ago died, a Methuselah of ninetyfour. Like the Spire of St. Stephen's, which he painted so often in all lights, he, too, is one of Vienna's signmarks. In his case we have to consider a whole dynasty, for his father Jacob (I789-1 872) was an excellent painter of city views, and his brother Franz (born in $182 \mathrm{I}$ ) is so still. The "Veduta," or view, was in the family blood. But Rudolf was also highly interesting as a figure painter, and the crowds of figures in his views of Vienna form a rich source of information, covering about eighty years of Viennese life. His abandonA ii 


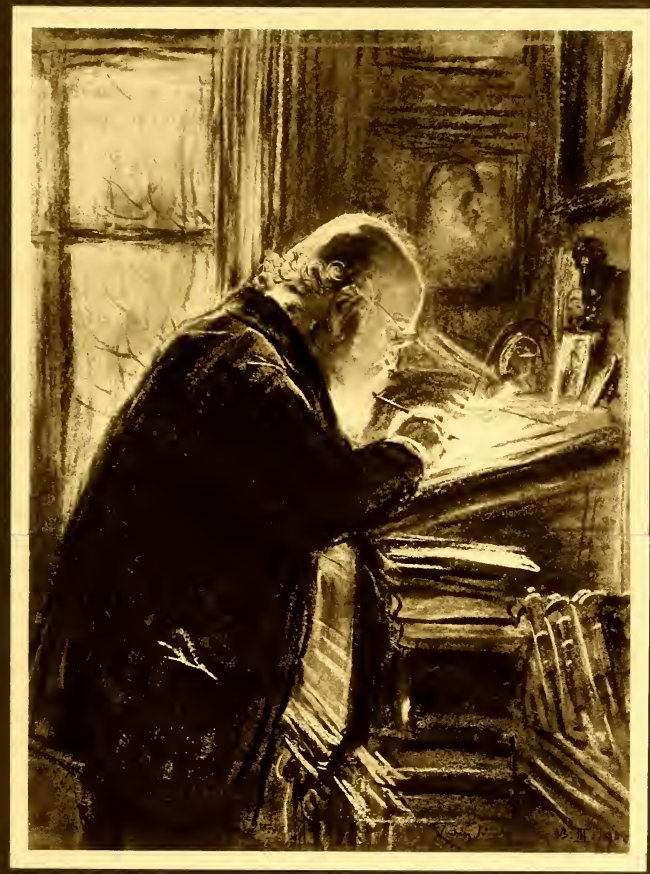

MOERAT PROF THEODQR COMPERZ PASTEL 



\section{MODERN PAINTING IN AUSTRIA}

ment of portrait painting, while still a young man, was a sheer act of friendship to the lithographic portraitist, Kriehuber, with whom he did not wish to come into rivalry. Rudolf was the leader of the Viennese "Veduta" painting, the true biographer of Vienna, old and new, the indefatigable chronicler in whose water-colours and marvellous pencil-drawings a whole world of picturesque beauty, now demolished, continues to live. His was an honest, cheerful, and domestic character, and he was as a painter quite simple, ever absorbed in his task, and producing easily and tirelessly-in fact, a real type of the Austrian and the Viennese in the days of the "Waltz King," Johann Strauss, and the local, dramatic geniuses, Nestroy and Gallmeyer. Sprung from the Viennese people, he was a genuine son of the soil, to which he clung all his life, full of its scent-the "Wiener Luft "-full of the spirit of the century, on whose sundial, year in, year out, the shadow of St. Stephen's Spire performed its round. In Vienna they call such an one an "Urwiener." Moreover, he made several journeys, which extended even to the Crimea and to Sicily. In Italy he painted many delicious pictures, at first working in oils, in which he was always somewhat heavy. He never went to Paris, and thus remained free from its influences. $\mathrm{He}$ was original through and through, yet at no time did he allow his originality to ossify into mannerism. He gladly let himself come in contact with all the tendencies of the period; he was always up-to-date and opportune, and we can immediately tell the period of his pictures, even though they be undated. It is remarkable that the author of the minute detail work of early years, of the Biedermaier period and the so-called "Vormärz," should have acquired, in the freer and more decorative Makart days, such breadth and richness of brush, as though he had never had aught to do with the laboured drawings of old Vienna; and in later years, when his trembling hand made writing almost impossible to the old man, he invented for himself a method of forming his characters with the tip of his brush, point by point, never failing to hit the right place. Then came the "pointillist" movement in Paris, and one saw that from sheer physical necessity Alt had long anticipated it. Thus all the styles and modes of painting of a whole century are reflected in his work. Even in his early water-colours, done in the thirties of the century, one often finds him busy with the problems of to-day-as when he depicts the play of the full sunlight on some broad plane, or paints in oils a Viennese eclipse of the sun $(1842)$ simply as an atmospheric occurrence, as a study, quite in the modern spirit. At the sale of his works by auction, in

A iii 
February last, the lots numbered 487 (two-thirds of which were small pencil studies) and realised 181,000 Kronen. There one came across many "incunabula" of modern painting. Rudolf von Alt is now on the road towards the attainment of international celebrity, after living out his long life in bourgeois modesty, content with nothing more than mere local appreciation. Indeed, of recent years the Berlin historical exhibitions have recognised his rank. $\mathrm{He}$ was the great, the real recorder of Vienna's doings, just as Adolf ven Menzel was the faithful chronicler of Berlin. Two diverse, yet at the same time parallel natures, which an essentially historical century created its representative artists. Menzel, as a son of politico-historical Prussia, as a contemporary of Ranke, depicted the story, internal and external, of his native land; while Alt, product of a Southern land full of charm of form and colour, native of a delightfully situated art-city, became, before all else, the delineator of his own locality, its landscapes and its views. When, on the $3^{\text {rd }}$ of April, I897, nineteen young artists came together, to found the $V$ iennese "Secession," they chose as their leader Rudolf von Alt, and he accepted the title. They found him young enough, and he felt himself not too old to be young in their society.

Meanwhile the "Secession" had become absolutely indispensable in Vienna. A too businesslike point of view prevailed at the Künstlerhaus, manifesting itself in the shape of something like a protective duty on art. For many years the exhibitions had prohibited the admission of all foreign contributions, in order to preserve the market for the home artist. Thus the great public was kept in complete ignorance of the various transformations which Western art was undergoing. Viennese painting might continue to hobble peacefully along the old, well-worn track! International exhibitions were few and far between, but the third of these (in the spring of 1894) gave some sign of what was going on in the West. This sign came, not from France-which still sent nothing but officially-approved works, naught of Manet and his school-but from England. For, in addition to Leighton, Herkomer and AlmaTadema (whose Fredegonde was bought by the reigning Prince of Liechtenstein for 15,000 gulden, and bequeathed later to the Modern Gallery), one saw here for the first time the "Boys of Glasgow"-Brown, Cameron, Reid Murray, Pirie, Macaulay Stevenson, and others, whose open-air work caused a complete upset of existing ideas. The storm thus raised came to a climax in December of the same year, when the entire "Secession" of Munich appeared as guests in the Künstlerhaus. The old-fashioned public A iv 
A. 8 O. MOLL.

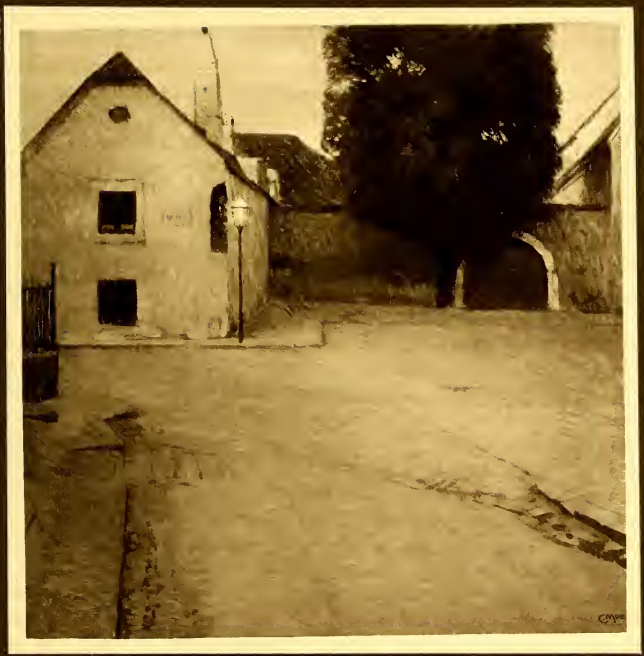

BEETHOVEN'S HOME IN TEIHGENSTADT" 


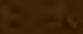


and its antiquated painters jeered loudly, but the iron wall which hitherto had formed the horizon of Viennese art was broken down. Some young artists were elected as members of the "Jury" of the Künstlerhaus, and soon there followed exhibitions of modern pictures-such as Segantini's Two Mothers, Dettmann's Heilige Nacbt, \&c., which of course aroused another storm of criticism. In the "Jury" itself there were hard battles to be fought, and finally the "young men" withdrew, to form their own society, the "Secession." From that time forward Viennese painting gravitated towards the "Secession" until the schism occurred last year. It modernised the whole art of Vienna, so that even the Künstlerhaus itself was compelled by force of circumstances to fall into line. Fresh forces were moving in all directions, the rejected of former "juries" emerged from obscurity into fame, and other groups of young artists were formed, notably the "Hagenbund," and applied art followed in the path defined by art pure and simple.

Forthwith there sprang into prominence an artist who was destined to establish a style-Gustav Klimt, born in I862, the most significant and most original force in painting since Makart. His name is, as it were, a battle-cry ; to many people he became and has remained a veritable bête noire. His three great ceiling paintings for the aula of the University-Pbilosopby, Medicine, and Furisprudence-formally signify three years of the æsthetic civil war during which controversy raged even among the professors themselves until finally the artist, who was treated by the Minister, von Hartel, in the most correct manner possible, voluntarily withdrew the pictures and returned the sum he had already received for them. Klimt is the absolute, go-ahead, unmitigated artist, the very reverse of an everybody's painter. He has no regard for aught save his own artistic vision, and goes on his way, silent and reserved. Anything in the way of speculation with regard to the commercial side of his work, any thought of taking notice of the oft-repeated charge of morbidness, is absolutely remote from his mind. The segment pictures in the staircase of the Hofkunstmuseum and the ceiling paintings in the Hof-Burgtheater reveal a graceful draughtsman and a powerful colourist of the Makart type, with a certain suggestion of his luxury of hues. But the "unrest of the modern soul" soon asserted itself. In the play of light and vibration of colour, as exemplified strongly in his Scbubert, he allies himself with the most modern tendencies. The nerves of a nervous age quiver at fresh contacts. New aspirations arise in form and in colour, a new vision appears, the latent hauntings of everyday fancifulness, the 
unwitting dreamings of a world to all seeming so wide-awake. Jan Toorop observed these phenomena, but in another way. Whistler also saw them, and he, too, with other eyes. Klimt was akin to the one, in his fantastic scenes which are beyond anything seen before in their ornamental tendency; he reminded of the other in his women's portraits, wherein not the body only, but the soul, the temperament, seems to be revealed, wherein one sees not alone the coursing of the blood through the veins, but the very disposition of the nerves. His portraits and his landscapes are generally admired, and even the Philistine has by now become accustomed to them. They have been much imitated, and already Vienna has a plentiful supply of false Klimts. But his phantasmagorias, great and small, are still beyond the comprehension of the simpleton in art, for they really mark something new in ornamental painting. Whole series of pencil sketches from nature have been made for the terrific realism in every face, in every piece of foreshortening, in every pair of wrung hands. Something like a mosaic of vague metals and enamels, lovely as jewels to the eye, like the feerie of the Byzantine mosaics at Ravenna, Palermo and the Church of St. Mark, is the Fata Morgana which leads the artist on. The masterpiece among these trance-seen visions of his was the fresco decoration of one of the rooms at the exhibition of Max Klinger's Beetboven. A long frieze depicted the yearnings of unhappy humanity, which first seeks help from a knight in armour of gold, then finds consolation amid the rose-blooms of Poetry, and finally comes to Joy itself in the Freude of Beethoven and Schiller ("Seid umschlungen Millionen"). But on the way mankind must first pass by a multitude of human sins and vices, the prince of which is the hellish monster, Typhœus. And this Typhœus fresco is the most extreme example one has yet seen of Klimt's orgie of ornamentality. For months the artist worked on this decoration without fee or reward, content to lavish such splendour on this one opportunity, though it was believed that his pictures would subsequently have to be erased. But happily it was found possible to detach them uninjured from the walls, and they passed into the possession of a lover of art. Klimt's art is one of the highest refinement, but it is notably lacking in that "sweetness" which has made so much of the art of the 19 th century unacceptable to us. On the contrary, it has a certain harsh loveliness, like that of the Primitives, and the eye leaves it refreshed. Remarkable too is the originality of his handiwork. It suffices to look at a square inch of one of his paintings to recognise his touch immediately. Next among the "Secessionists" to demand notice are Giovanni A vi 


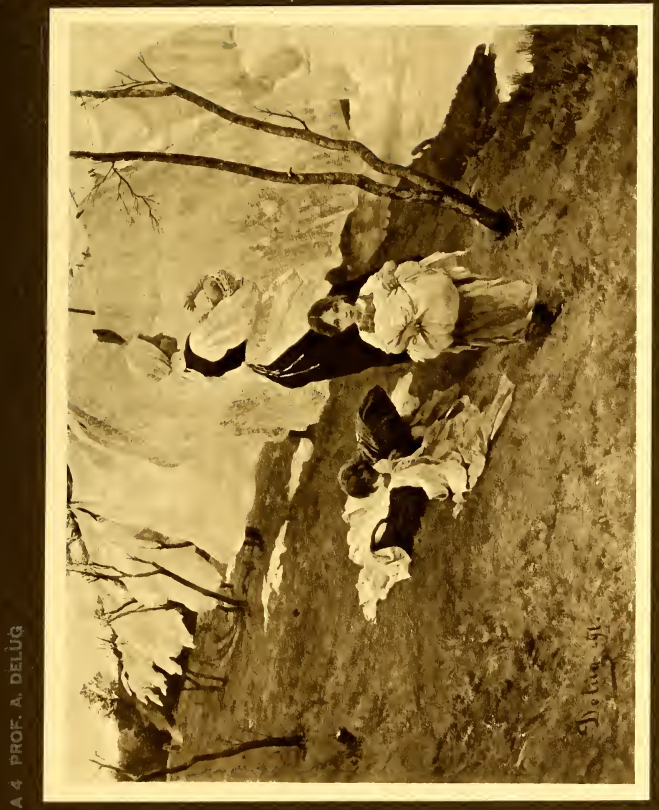



Segantini (I $858-1899$ ), from Arco, Southern Tyrol, and Josef Mehoffer, the Pole, born in 1869 , a professor at the Academy of Arts at Cracow. Of Segantini it is not necessary to say much here, for he was one of the best known painters of our time. Even that quaint method of his mature period, to paint by tiny single strokes, his simple "divisionism," was sufficient to make him unique. Moreover he is highly modern in the bold truth with which he depicts an earth nigh to the heavens, and in the "soul" - whereby I mean the poetical pitch and ethical glorification - which his absolute fidelity to truth in nature acquires. But Mehoffer is now the most powerful colourist in the monarchy. From the portraits and "society" pictures of his early days, when he resembled a Spaniard of the Zuloaga or Anglada type, he went on to mighty colour work, such as the stained-glass in the Cathedrals of Cracow and Plock, and more particularly in the Cathedral of Fribourg, Switzerland. Therein he revels in unrestrained luxury of form and colour, revealing, as it were, the deliberate abandon of the artistic temperament in a way scarcely to be seen elsewhere. In these glass-paintings the art of the church is suddenly raised to unexpected heights. Many forceful talents are now being specially applied to the solution of the ecclesiastical art problem. This is the period of Otto Wagner, who is now building in Vienna the first church designed on modern principles. Last winter the "Secession" held an important exhibition of Ecclesiastical Art, in which the Beuron style was for the first time publicly displayed. The Benedictine monks of Beuron Abbey, in the principality of Hohenzollern, have, thanks to the creative skill of Father Desiderius Lenz, possessed a new style of ecclesiastical art for thirty years past. To complete this presentation of the work of the Beuron school certain Viennese painters took part in the labour of painting a baptismal chapel. Each picture was by a different hand, composed in a different spirit, so naturally there was no very harmonious result, good as was each separate portion itself: but here I will do no more than mention the charming glasspainting by Ederer.

Among the style-inclined painters of the "Secession" there are several who strike an individual note, for example, Adolf Böhm (born in $186 \mathrm{I}$ ) in the ornamental stylisé landscape, with a strong leaning in the direction of applied art; Alfred Roller (born in I 846 ), who is at present a reformer of the established state of things at the Imperial Court Opera, where the classical scenes owe their novel anti-realistic form entirely to him; Rudolf Jettmar (born in 
I869), chiefly an etcher of fantastically-heroic scenes; Max Lebenwein (born in I 869), water-colourist, interpreter of knightly legend and saga, and J. M. Auchentaller, whose ornamental whirlings are influenced by modern English examples.

The popular element has two clever and truthful exponents in Josef Engelhart (born in 1864) and Ferdinand Andri (born in 1871). Engelhart is the son of a wealthy citizen, and lives in one of the most popular suburbs of Vienna. His brusque scenes of Viennese life are full of joie de vivre and fresh colour. There is strength and there is race therein. At the same time he is a man of international culture, who has painted in all kinds of styles in the ateliers of modern Paris, in the churches of Spain, and beneath the blue sky of Sicily. His plastic work, too, is ever gaining in strength, and he has been producing, in the way of applied art, original things full of excellent workmanship. In the house of the wellknown manufacturer, Herr Tausig, there is a room ornamented by Engelhart with large scenes from Wieland's " Oberon," most fancifully and gracefully disposed in the true decorative manner. Andri, on the other hand, is the jovial illustrator of peasant life, of which he depicts the various types and costumes (notably the gailycoloured cottons) with all vividness, and preferably in pastel. Moreover, he has higher aspirations, and, as occasiun serves, rises to great symbolic altitudes, as in the mural painting in the baptismal chapel already mentioned; and, lastly, his carving shows real mästria. Another important personality is Carl Moll (born in I 86I), one of the founders of the "Secession," which, however, he has quitted, to join the "New Secession." As a painter he proceeds from the landscape school of Schindler, having since rambled in the Hansa towns of North Germany, in the footsteps of Gotthard Kuehl. But only in the "Secession" did he became quite modern in the matter of light and colour problems, and that attitude he still adopts to the utmost extent. A virtuoso in regard to technique, he has had considerable success with his interiors, landscapes and views. But his personal role in the modernising of the art life of Vienna consists in his restless energy in the service of a pet idea, and in the sociable, business-like and diplomatic qualities which are requisite in the struggle to maintain these interests. He was the very leaven of the new movement, a Minister of Fine Arts without a portfolio. A man of the Ideal was also Johann Victor Krämer (born in I862), Engelhart's student companion in Spain and Sicily, and afterwards an Eastern traveller who put the sun of Memphis and Baalbek on his palette. His pictures of Palestine have a deep, almost a sacred tone. A viii 
A 5 FERDINAND ANDRI.

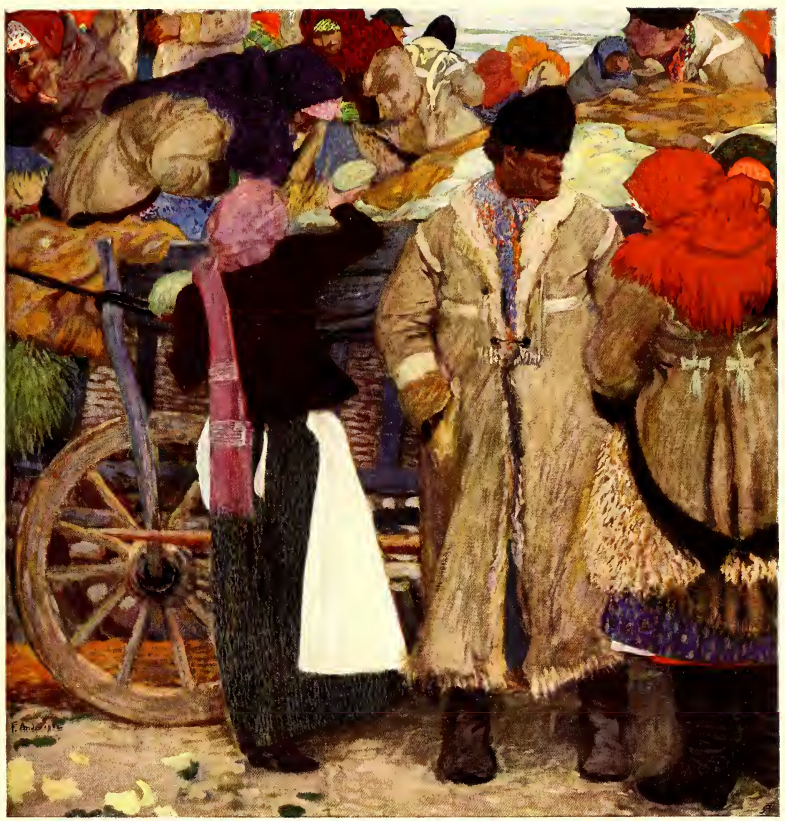




\section{MODERN PAINTING IN AUSTRIA}

His religious works, too, he steeps in the full magic of the plein air. Like him, Rudolf Bacher (born in 1862), now a professor at the Academy, comes from the good school of Leopold Müller-" the Egyptian." He possesses the serious, historical style-the solid, substantial art of painting; furthermore, he is one of our leading portrait-painters, and, incidentally, a delightfully humorous delineator of dragons and other "fearful wild-fowl," and a plastic artist to boot. He also did sacred work, and other such pictures have been done by Wilhelm Bernatzik (born in 1853), who also aspired to Viennese genre and lastly to modern landscape. He belongs to the energetic class, is an abundant producer, and was taught in Paris.

After Schindler's death Eugen Jettel (1845-190I) occupied a foremost place among our landscapists. He lived mostly in Paris, and belonged to the Barbizon School. A delicate, lyrical nature, to whom everything was a bright, sunny idyll. In his later years his art blossomed forth again in a series of delicate pictures of the Istrian coast, whose solitary, remote nature prompted him, under the influence of the sunshine, to the tenderest confessions. Ludwig Sigmundt (born in 1860 ) takes a high place to-day as a delicate and emotional painter of landscape. Inwardly he remains ever devoted to his familiar Steiermark scenery, and attempts nothing extraordinary ; but everyday Nature speaks to him in pleasant, intimate tones, and her light and her air permeate his canvases. The charm he has extracted from homely themes has often caused surprise. The same simple wild-flowers are picked with firmer grasp by Anton Nowak (born in 1865), who grows in ability year by year. A poetical dreamer in landscape and figure-work, who had early and notable success, is Maximilian Lenz (born in 1860 ), and he has, moreover, learnt the secret of the exotic world of the Pampas of Argentina. A moonlight romancer is Ernst Stöhr (born in I 865); a pensive teller of fairy-tales, Friedrich König (born in 1857), over whose shoulder the "muse" of old Schwind is still peeping. In 1897 there returned to Vienna the brilliant Parisian illustrator - erstwhile officer in the Austrian service-Felician, Baron Myrbach, who was born in 1853 . He came back to be the Director of the re-organised "Kunstgewerbe-Schule," a post he has now resigned. A good all-round man, skilled in figure-work and landscape, he nowadays affects the modern method. W. List, Anton Müller, the "Viennensia" painter, Otto Friedrich and Hans Tichy also belong to this group.

In the "Hagenbund" there are also several painters who stand out as individual forces. Ludwig Ferdinand Graf (born in 1868) went, 
when quite young, to Paris and Brittany, and brought back with him sundry experiments with broken and pulverised colours, piquant discords and dainty absurdities. In addition to interiors, landscapes and portraits he devotes himself to visions such as never were seen; they are very personal, even when he has a model. Each year he becomes different, ever seeking something new, but his tendency is always towards style. Indeed, in painting landscape he has already produced interesting work. Altogether original is Wilhelm Hejda (born in 1868), painter, sculptor, maker of furniture and discoverer of polychromes in new ceramic elements. Here we have simply to remember his pictures, which in their simplicity of production often attain to charming effects, and are always possessed of a certain style which commands attention. An uncommonly skilful designer, inventor, water-colourist, draughtsman, illustrator and costumier is Heinrich Lefler (born in I 863), who, in conjunction with his brother-in-law, Josef Urban, the architect, illustrates fairy-tale books, large and small, in colours, and, furthermore, has decorated the Rathskeller in the Town Hall with mural pictures of jovial Viennese life throughout the centuries. He was director of the costume department at the Imperial Court Theatre, and is now a professor at the Academy. He has not lacked for models to imitate-Boutet de Monvel and Vogeler-yet he has much original skill and charm, and the ready dexterity of the born improvisator. To a somewhat older generation belongs another member of this group, Alexander D. Goltz (born in 1 857), who, like all the pupils of Anselm Feuerbach, sets his poetic feeling in a minor key. He has followed the currents of his time as best he could, without cutting out a special course for himself. From the atmosphere of Paris, with its cabarets and café-cbantants, Raimund Germela (born in I 868) came home a fullcolourist, at least on a small scale. His canvases overflow with the pleasure of living, especially in his park scenes, which display a stylise luxuriance. They are closely allied to the work of Somoff and the "Simplicissimus," but without their humour. On occasion he makes a "raid" into the domain of Socialism. Among the landscapists of this group must be mentioned Kasparides (since resigned), Konopa, Wilt, Ranzoni, Zoff, Ameseder, Suppantschitsch and Baar. In the "Hagenbund" we also came to know the Dresden couple, Karl Mediz (born in 1868) and Emilie Mediz-Pelikan (born in I862). They followed an almost identical path of expression and development, which led them to Dachau, to Uhde and to the Belgian fishing village of $\mathrm{Knokke}$ - some of the head-quarters of impressionist students. Both husband and wife have a picturesquely fantastic vision of things, A $\mathrm{X}$ 


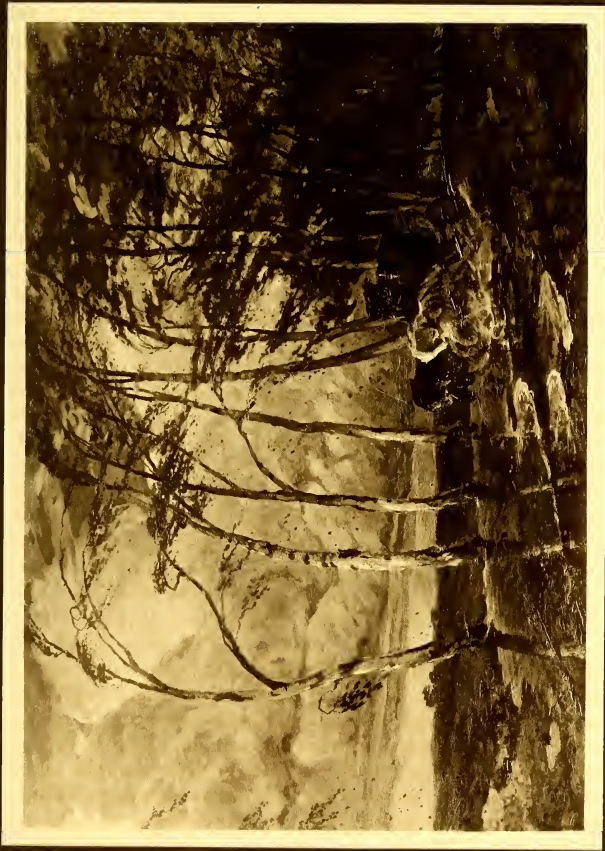





\section{MODERN PAINTING IN AUSTRIA}

which, in their representation of ice-clad mountains, becomes quite stylisé; and in contrast to a background of panoramic character, the foreground is depicted with almost microscopic accuracy. Thus Karl Mediz paints every thread, every hair in his life-size Eismänner, which made his reputation and now hangs in the Modern Gallery; and in the same way Emilie Mediz-Pelikanin, her slender little trees in tubs, which she generally likes to place on some terrace on a Southern sea, depicts even the tiniest crack in the bark. They have both painted much in these Southern seas-chiefly about Corfu-and have studied the blue deep with a bird's-eye view as it were. Karl Mediz is also a master of portraiture. He has done quite a series of portraits of persons in Dresden society, all executed with minutest precision.

The contribution of the Slav races to the artistic assets of the Monarchy is very considerable. With them æsthetics are at the same time politics, and artistic growth means also an increase of national importance. The success of such a standard is naturally great, though in a land divided in its language there is of necessity a tendency to division of materials and means. Thus in Galicia we have Poles and Ruthenes; in Bohemia Czechs and Germans. The Poles have already great traditions, and a patriotically historic art in the great paintings of Jan Matejko (1838-1893), and Artur Grottger, who portrayed the stirring tragedy of the martyrs to freedom (1837-I867). But modern times have even here wrought great changes, and the national temperament now seeks expression rather in the highly-coloured and "ethnographische" style. We have already mentioned the window paintings by Mehoffer at Fribourg. These, as also those of Stanislaus Wyspianski and other religious painters like Leon Wyczolkowski (b. I 852), are of a romantic and symbolical character that verges on the fantastic. Nature and the various phases of the native peasant life are represented in an impressionist manner by Joseph Chelmonski (born in 1852), Jan Stanislawski (born in $\mathrm{I} 860$ ), and more stylistically by Ferdinand Ruszczyc and others. A note of the past is struck in certain political paintings of a seditious character, such as Etape (Students on the way to Siberia) by Jacek Malczewski (born in 1855). A more international spirit of the stamp of the newer Munich school is that of Julian Falat (b. I 853), one of the most enterprising of snow-painters. A hunting guest of the Emperor William, he has immortalised many imperial shooting scenes. He is the director of the School of Art in Cracow. Adalbert Kossak (born 1857 ) is a painter of battle-pieces and Peter Stachiewicz (b. 1858) a delicate 
legendary painter of the life of the Virgin. Kasimir Poehwalski (b. I 856), at present professor in Vienna, a painter of elegant portraits in the manner of Bonnat, is now striking out in a more modern style. Zygmunt Ajdukiewicz (b. 1 862) is a genre painter in an older style with a predilection for painting horses, also an illustrator of the revolutionary episodes of Kosciuszko. Thadeus Ajdukiewicz (b. I 852) is a refined painter of equestrian, military and sporting portraits.

The Czechs, though they entered the lists later than the Poles, have, nevertheless, soon become their artistic equals, standing high in the modern Parisian art world, as in the case of the late Ludek Marold (1865-1898), who in Paris and Munich was considered a brilliant genre painter, mostly in water-colours; and Alfons Mucha (born I 860), Sarah Bernhardt's poster artist and illustrator of "Ilsé Princesse de Tripoli," etc., who, however, never lost his early piquant peculiarities of style, for instance, his wire-like curling of women's hair. Parisian elegance, which however found a speedy limit, was also a characteristic of Adalbert Hynais (b. 1854), who did his best work in the auditorium of the Burg-Theater. $\mathrm{He}$ is a professor in Prague, with the military painter Rudolf von Ottenfeld, the painter of sunshine Franz Thiele, who studied in Italy, the Parisian pointillist Vlaho Bukovac, a Dalmatian, and the over-sophisticated mystic Maximilian Pirner. Much fame has been won by the two landscape painters, Antonin Slavicek (b. 1870) and Antonin Hudecek (b. 1872), both ardent seekers after new colour effects.

At the present time the four principal artists of the Czecho-Slav nation are Hans Schwaiger, Joz̈a Uprka, Max Svabinsky, and Emil Orlik. Hans Schwaiger (b. 1854) is the quaintest. His name conjures up visions of Wandering Jews, Anabaptists, Sorceresses, Gallows-birds, the Gnome, King Rubezahl, and the Waterman of the frog-pond. He is an untiring fairy-tale teller, and seems to have lived through all his brilliant extravaganzas and blood-curdling ghost stories. For many years he dwelt in a wooden house in the middle of a wood on a spur of the Karpathians. A woodman, well versed in all the secrets of the forest and of the slovaque legends, abroad an intimate of poachers and vagrants, and at home surrounded by ancient curios, a dabbler in magic, something of an alchemist, magician and devil worshipper, no wonder that Chaucer's "Canterbury Tales" and the old Simplicius Simplicissimus furnish his favourite reading and much of his inspiration. $\mathrm{He}$ is an "original," and what he draws or paints-mostly in water-coloursdisplays a gnarled rusticity and a queer fanaticism. The spirit A xii 


\section{A.7 MAX SVAËNBKY}

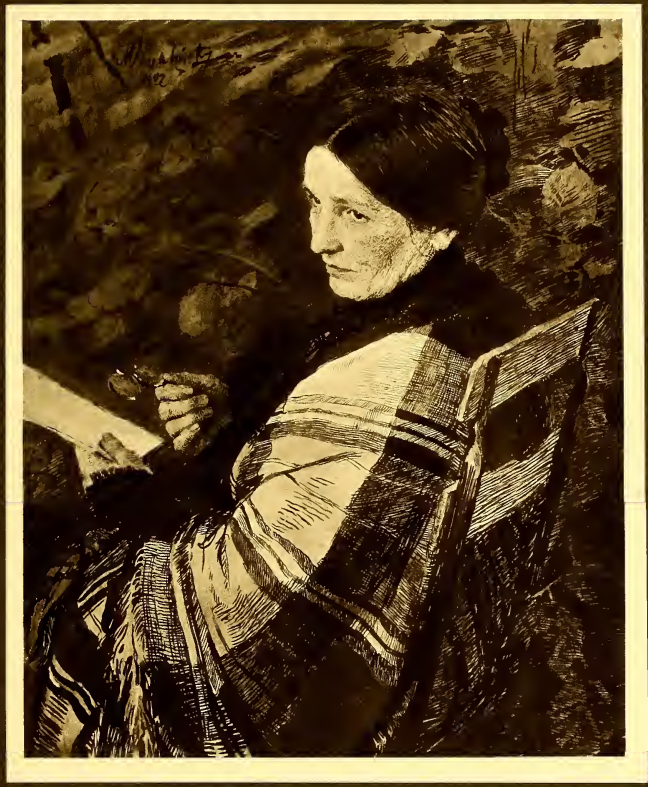

PORTRAIT OF A. LADYWASH AND PEN-ANDUINK DRAWING 



\section{MODERN PAINTING IN AUSTRIA}

of the old German woodcutter seems to have revisited him, the sturdy humour of the cobbler Hans Sachs, and the perilous practical joke of the Thirty Years' War. His principal picture is an enormous water-colour, The Anabaptists, an incalculable turmoil of quaintlyapparelled and desperate-looking people of that reckless period, masters and servants, soldiers and women, fanatics and fools, demigods and cripples, all massed together, a kaleidoscopic picture of the age. Schwaiger's humour, his phantasy, his spirit lore, his inventive power are inexhaustible, his paintings are legion. Later he found his subjects in the old towns of the Netherlands, but since he became professor at Prague, he has given little of his art to the world. The second "original" is the Moravian peasant-painter, Joz̈a Uprka (b. 1862), who lives and works in the unpronounceable Hroznova Lhota. His invariable theme is the peasant-life of that place, whose unquenchable colour and movement he depicts on his canvases. These weddings, rustic feasts, harvestings, avalanches of gay colours in the most brilliant sunshine, excite much interest, though they are quite drawing-room affairs modified into prettiness. According to him his country only produces beauties. His sudden success, however, has not spoilt him; he works earnestly at the conquest of the whole scale of Nature's mood as he finds it at his threshold. Filled with the same patriotic spirit, centred on his own span of earth, is Jaroslav Spillar, who unfortunately has of late become mentally deranged. He devoted himself exclusively to the portrayal of one of the most ancient races, the Chodes in western Bohemia, who observe ancient customs and preserve a most magnificent national costume. An energetic and productive genius is Max Svabinsky (b. 1873) of Prague, a graphic artist who devotes much attention to contemporary portraiture. $\mathrm{He}$ has devised a peculiar technique of coloured pen-sketches. Over a heavy groundwork of strokes he lays a delicate layer of water or pastel colouring. The effect is original and rich; also in lifesized heads, figures and scenes the technique is effective, and has made him a specialist in this line. Again, there is Emil Orlik (b. 1870), a man of unusual talent, a universal painter in all styles, but with a genial turn for realism. He passed many years in Japan, where in friendly intercourse with the artists of the country he fathomed the secrets of the Japanese coloured woodcuts, which he varied and appropriated to his own use. Besides this Japanese speciality he has of late years turned his attention to things nearer home. The old houses and courtyards of the Bohemian and Moravian villages, the old-fashioned costumes of the provincials, their neatly kept interiors, 
the whole sober, dainty, childish world which in each dwelling revolves round its centre point, the family patriarch, he portrays with a naïve virtuosity all his own. Also as water-colourist, pastellist, etcher, lithographer, draughtsman in all styles, he is a great inventive personality. The leading German collections (Dresden, etc.) possess all his work. Last year he was nominated professor at Berlin.

In the old Vienna Artists' Association, whose home is the Künstlerhaus, modern views are now universally adopted, though there are still many representatives of older schools who preserve their adherents. In the field of portrait-painting conservatism is still a strong element. Two of the elder celebrities of this branch are Leopold Horovitz (born in 1 843) and Heinrich von Angeli (born in 1840). Both have painted distinguished personages for years past. In the seventies of the last century Angeli was Court painter of Austria, Prussia and England, in partibus. Queen Victoria and her daughter, afterwards the Empress Frederick, employed him considerably; the English nobility sat to him gladly; so did the Viennese Court, with the Emperor Franz Josef at its head. Horovitz had his aristocratic clientele chiefly among the Hungarian and Polish magnates, the celebrated politicians of those countries, e.g., Koloman Tisza and Pulszky, and interesting women such as the Princess Sapieha, Countess Potocka, the Berlin beauty, Countess von der Groeben, and the Viennese lady, Frau Dr. Loew, of whom he did a remarkable portrait. The best recent portraits of the Emperor Franz Josef are by Horovitz: one of these, in British uniform, was painted for his English regiment. These masters combine the qualities that were so highly prized at that time, and many of their paintings have successfully resisted the changes of fashion. It is interesting that they should both have been born in Hungary; moreover, there are three Hungarians now figuring prominently in Vienna as "high-life" portrait-painters-Philip László, Arthur von Ferraris, and Josef Koppay. Although they have become more and more firmly established in Vienna, yet they cannot be considered as belonging, properly speaking, to the school of Austrian painting. Furthermore, their international fame keeps them busy in all parts of the world, and they are continually travelling from place to place. All three have their peculiarities in the matter of style, and on these their positions depend. László proceeded by way of Lenbach towards Gainsborough and the English colourists, when he met a fellow traveller in the person of Koppay; while Ferraris has been schooled in the elegance of Paris. Other prominent portrait-painters include Viktor Stauffer (born in 1853), Canon, Hans Temple, Julius Schmid; xiv A 


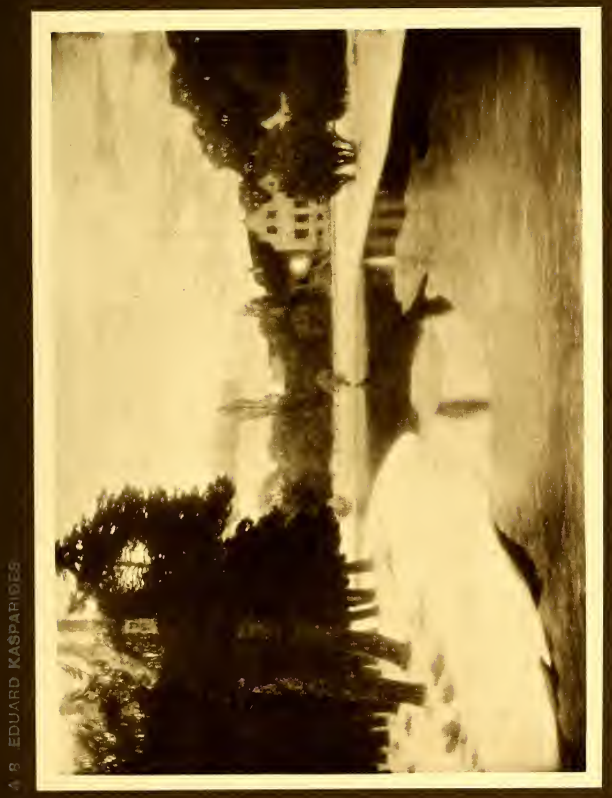


and among the quite young men but newly "arrived," John Quincey Adams, Joannovits, Schattenstein, Schiff, and Victor Scharff (born in 1872 ), who while in Paris was a gifted pupil of Whistler, and since then has painted a good deal in Volendam, Holland. Ludwig Koch cultivates the sporting portrait, which he handles with vigour and freshness.

In genre painting various men of talent are to the fore-artists of the older school, like Franz Rumpler, that graceful eclectic, or the more modernised Alois Delug, now a professor, and a striver after greater things. Both of these men have found their own right mood. Others are Eduard Veith (born in $185^{8}$ ), who has adopted the English fairy tale style; Charles Wilda (born in 1854), who has turned his back on the flesh-pots of Egypt to seek the cooler joys of Lower Austria ; A. H. Schram (born in 1864), a rather fanciful colourist, who has, however, relapsed into excess of "sweetness," even in the agreeable work he did in Damascus last year; Alphons Mielich (born in $186_{3}$ ), a still more pronounced Orientalist, who, with Professor Musil, discovered the ancient Arabian desert castles, Amra and At-Juba, and copied their wall-paintings. Some have gone abroad : to Paris, Eduard Charlemont (I 848 - I906), who executed the ceilings - 54 metres long-in the foyer of the BurgTheater ; to Rome, Adolf Hiremy-Hirschl (born in 1860), who became "modern," after having copied the style of AlmaTadema in his scenes of ancient life. In Albin Egger-Lienz (born in 1868 ) we have what may be called a posthumous historian. $\mathrm{He}$ has painted the story of the Tyrolese fight for freedom of 1809 in pictures large and small, big events and little episodes, all conceived in sombre and heroic spirit, but abounding in modern effects of colour, and broadly and freely painted with the hand of to-day. The great historical school of other days has died out, but a few notable survivors remain: Sigmund L'Allemand and Julius von Payer, the famous Arctic explorer and discoverer of Franz-Josefs Land. The local Viennese genre picture in the style of the old petits-maîtres has more or less esteemed exponents in Anton Müller, Kinzel, Hessl, Baron Merode, Zewy, Gisela, and others. Isidor Kaufmann (born in 1853) cultivates the Jewish genre style with an old-fashioned "ethnographische" particularity and a neat solidity which recall the early Dutchmen. In landscape the long enervated School of Lichtenfels is dying out. From the Schindler period there remain several excellent artists, whose lyrical charm never fails to find admirers. At the head of these stands Hugo Darnaut (born in $185 \mathrm{I}$ ), while the others include Rudolf Ribarz, who lived for 
many years in France, and died recently; Hugo Charlemont; Ludwig Hans Fischer, who travelled and painted in Egypt and India; Benesch Knüpfer (in Rome), who has watched the naiads of the Latin Sea; Eduard Zetsche, who has painted graceful monographs of our ruined castles; Robert Russ, who has bathed in the sunshine of the South Tyrol; - and the old, but rejuvenated August Schäffer (born in 1833), Director of the Imperial Picture Gallery, who forms a link between the present and the past. Modern in his landscapes and "Veduta" work is Karl Pippich (born in 1862) and ultra-modern Heinrich Tomec (born in 1863), both of whom are interested in rare aspects of light and colour. Then we have Friedrich Beck, with his novel impressions of snow scenes; and, lastly, Rudolf Quittner.

Neither has the reproductive art of Vienna been idle these last few years. The spirit of the new age no longer meets with opposition, even the schools recognise the policy of "the open door." In the albums of the meritorious "Gesellschaft für vervieltältigende Kunst" (Society of Reproductive Art) the modern style of graphic art fills the chief place. As a teacher the first position is still held by William Unger (born in 1837), the old master from the old galleries. He gives free rein to his pupils. They etch-in colours, too-quite in the modern spirit. A strongly independent and versatile painter-etcher is Ludwig Michalek (born in 1859); and effects even more powerful have been realised by Ferdinand Schmutzer (born in I 870), a natural black-and-white artist of uncommon force, who has turned out plates of $1 \cdot 20$ mètre and even $1 \cdot 50$ mètre high. The first of these represents a young horsewoman, the second the Joachim quartet. Whistler, the Prophet of the little, delicate plate, would have crossed himself at sight of such excesses. The foremost portrait-etcher in Vienna to-day is Schmutzer. His strength is shown in his large portraits of Rudolf Art, the painter, and Paul Heyse, the poet, also in the smaller, but artistically richer, portraits of Professor Gomperz and Joachim, the world-famous violinist. The popularity of the eau forte is now so widespread that there actually exists an etching club for ladies which has issued several interesting albums. At the Kunstgewerbe-Schule, the Myrbach School was, until the resigning of that artist, a trainingground for all descriptions of the graphic arts-the poster and the caricature included. 


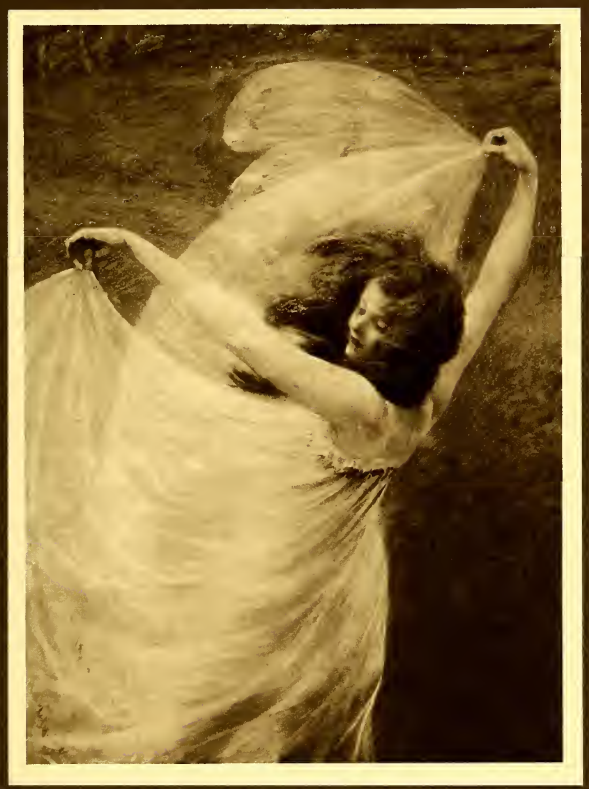

"THE WIND" -PASTEL 



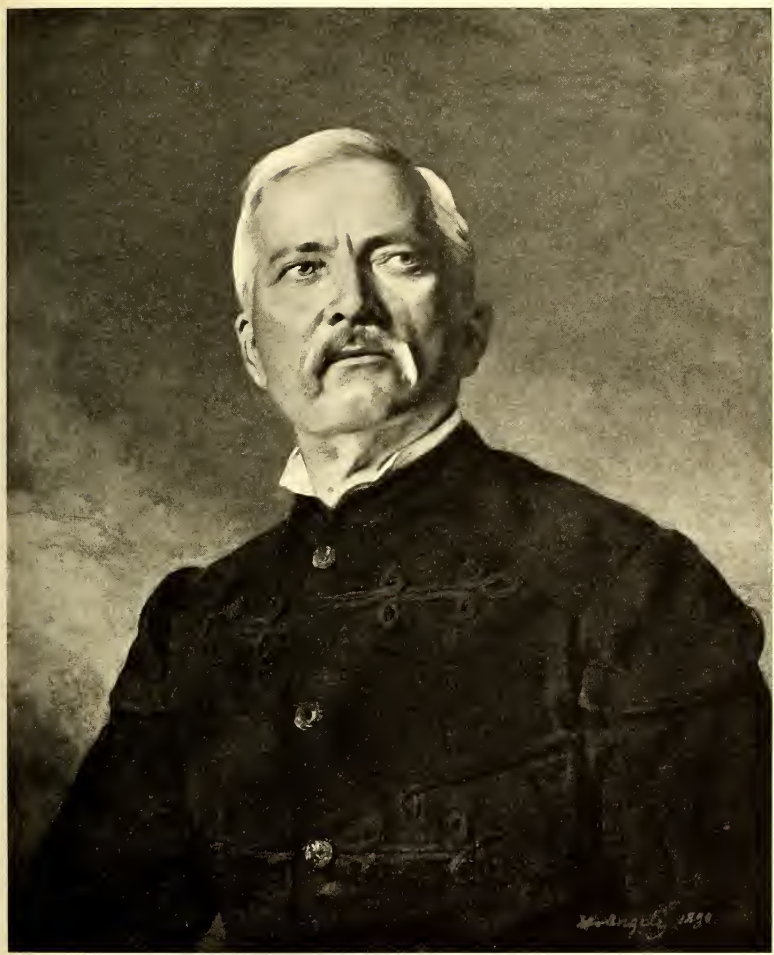




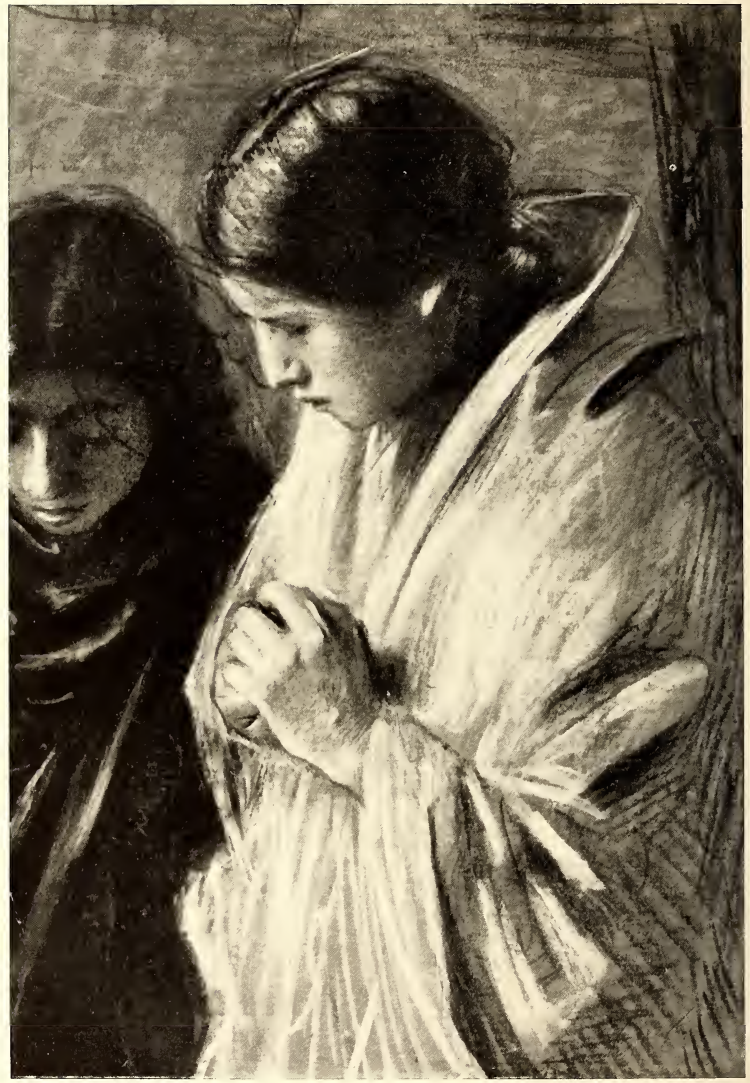

PASTEL STUDY FOR "A PROCE\$SION" 


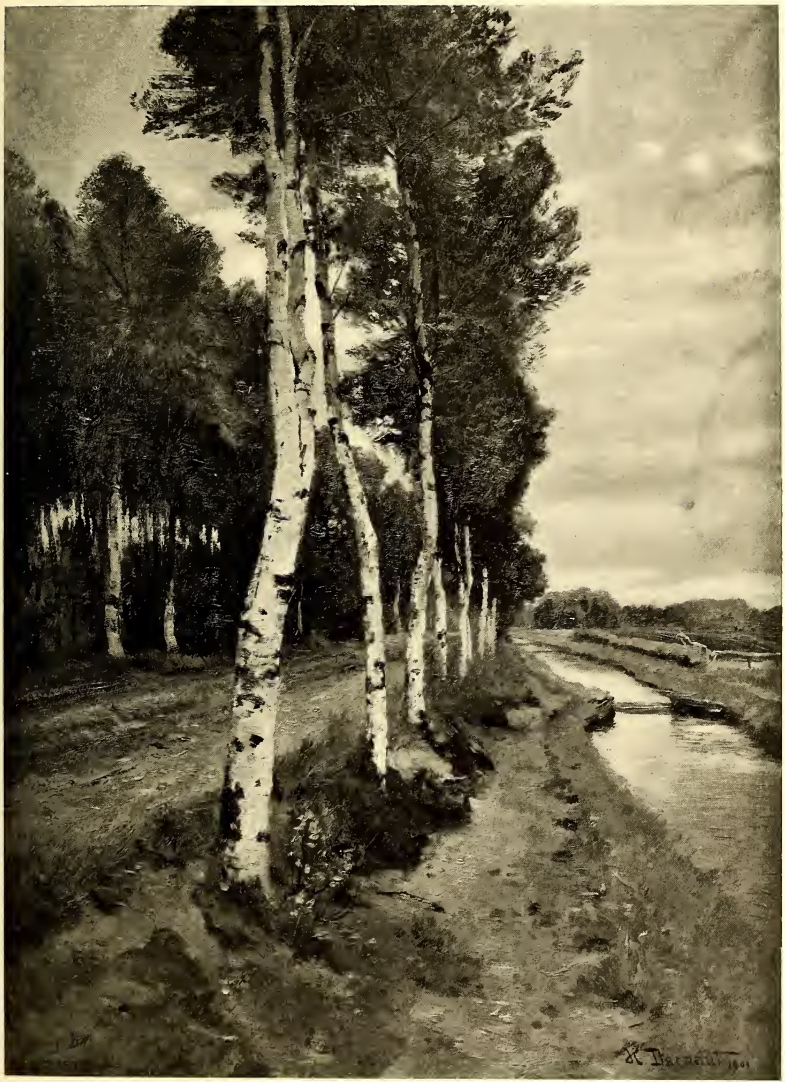


A 13 LUDWIG FERDINAND GRAF

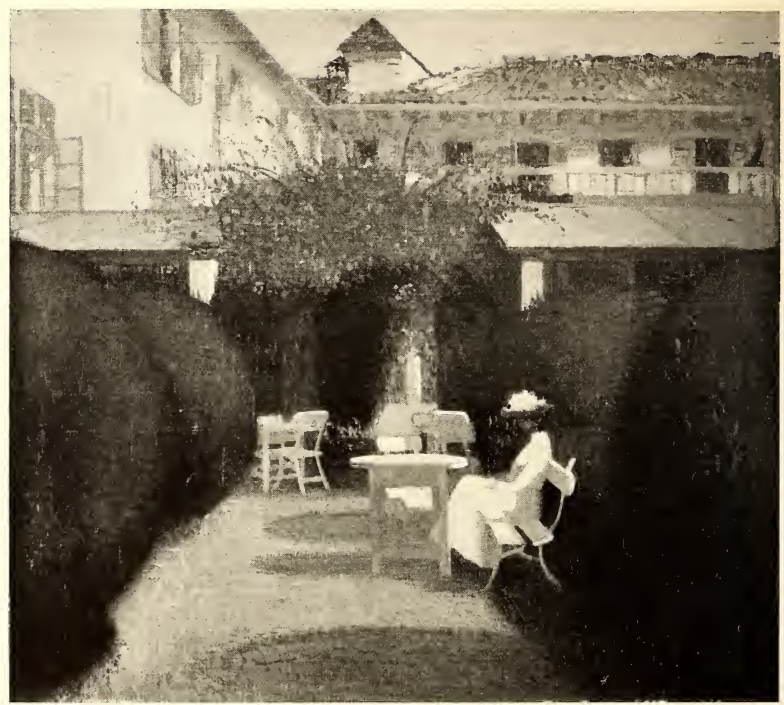




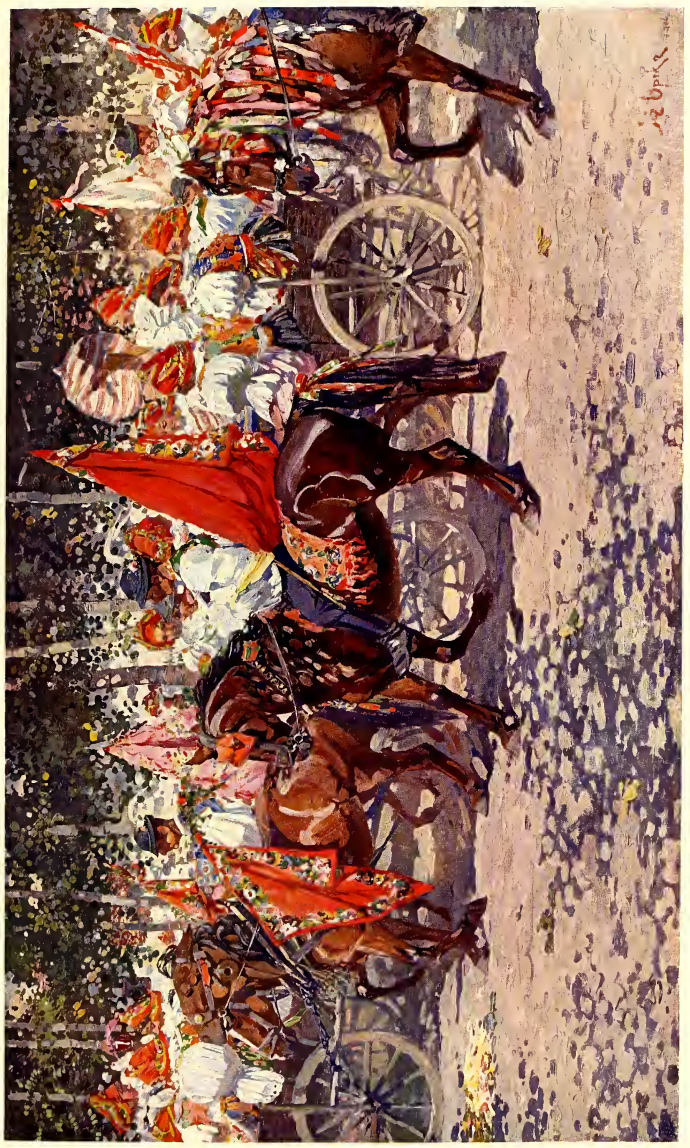


A 15 WALTER HAMPEL

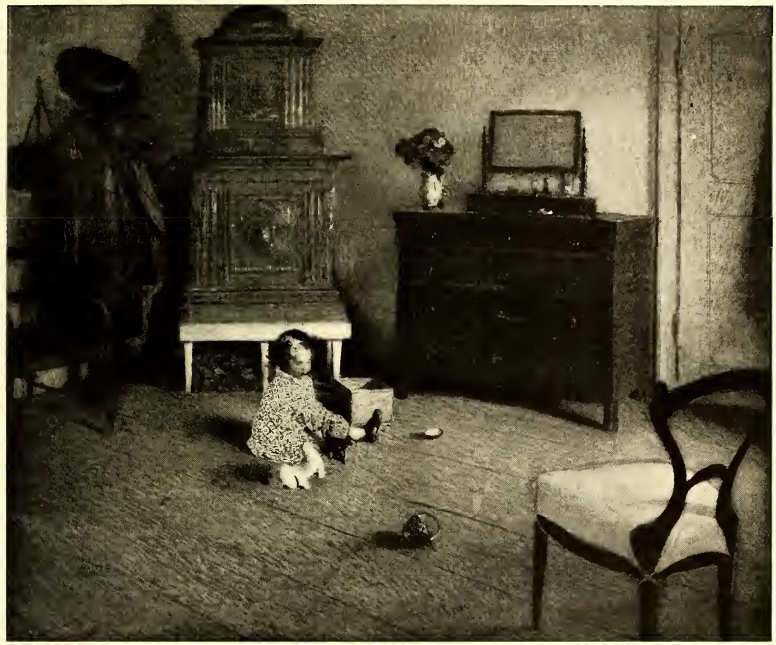




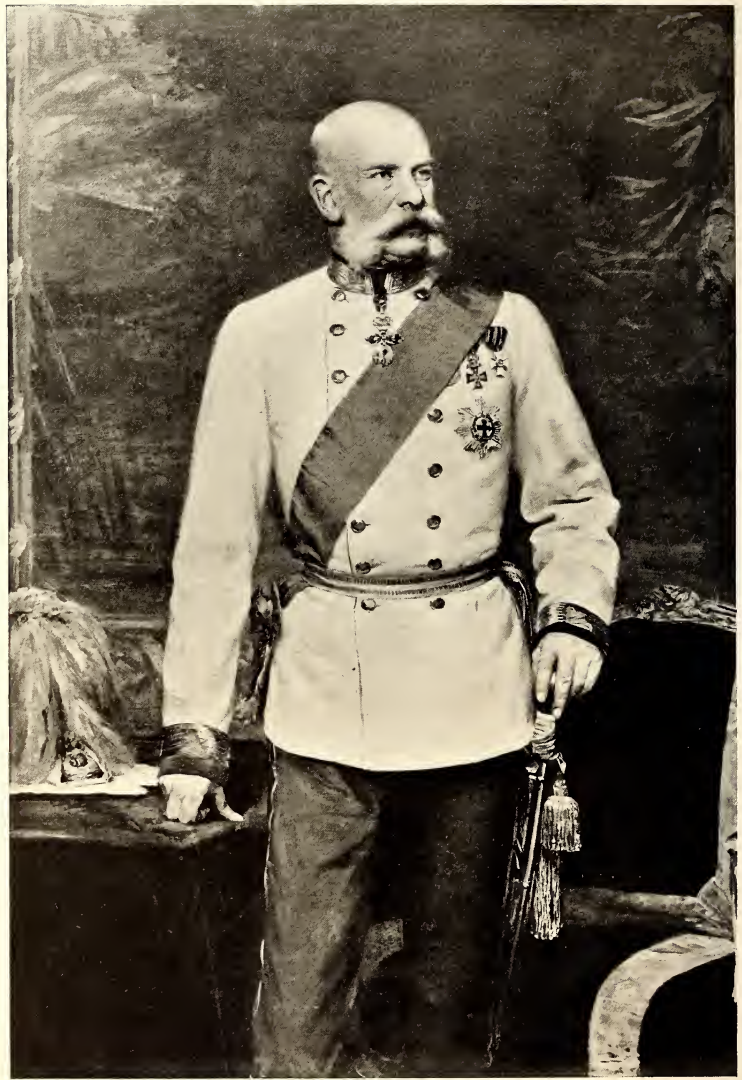




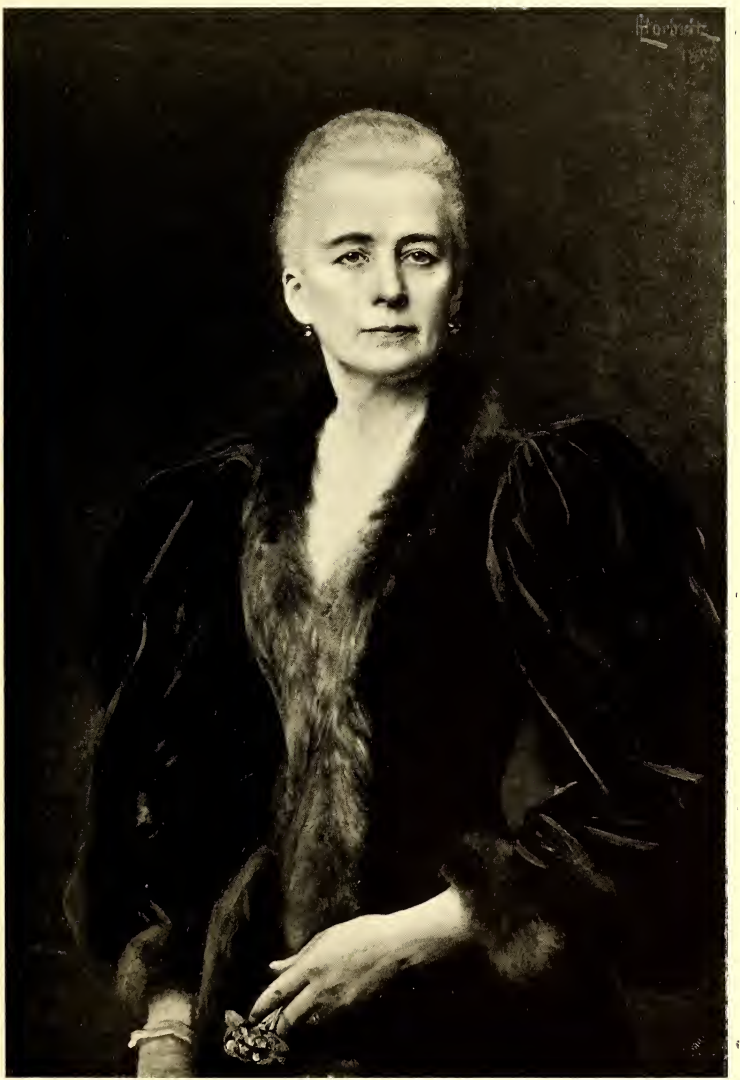

PCRTRAIT OF COUNTESS POTOCKA 


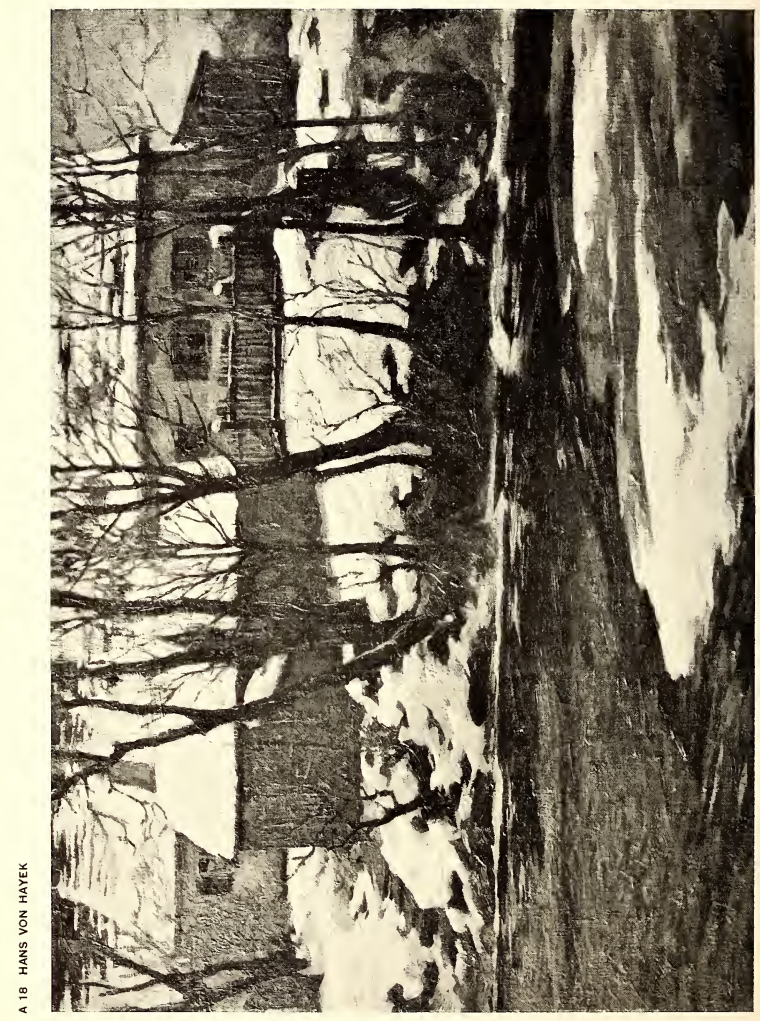

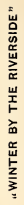




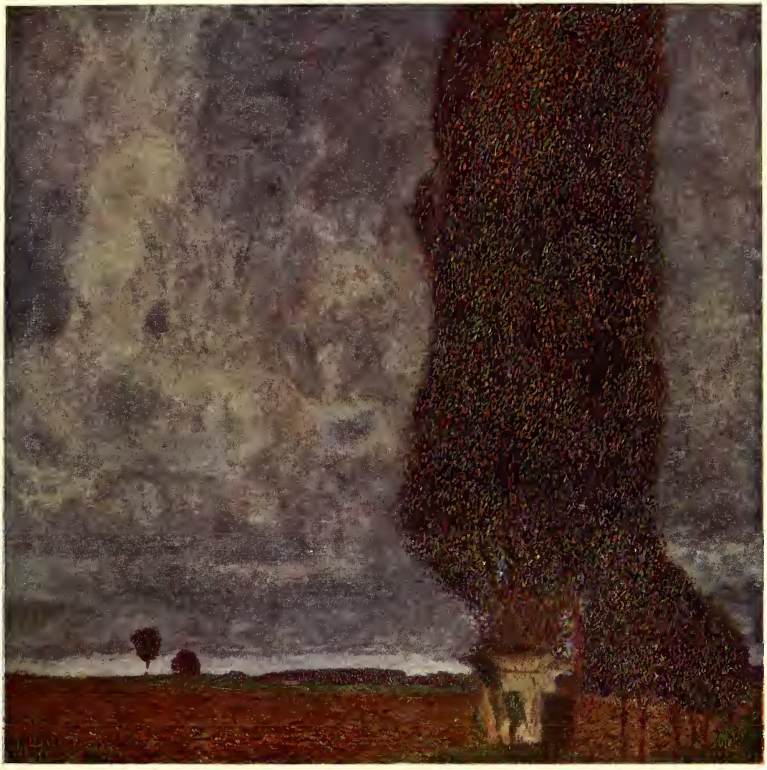

"THE BIG POPLAR" (BY PERMISSION OF THE MIETHKE GALLERY OF FINE ARTS, VIENNA). 

A 20 GUSTAV KLIMT

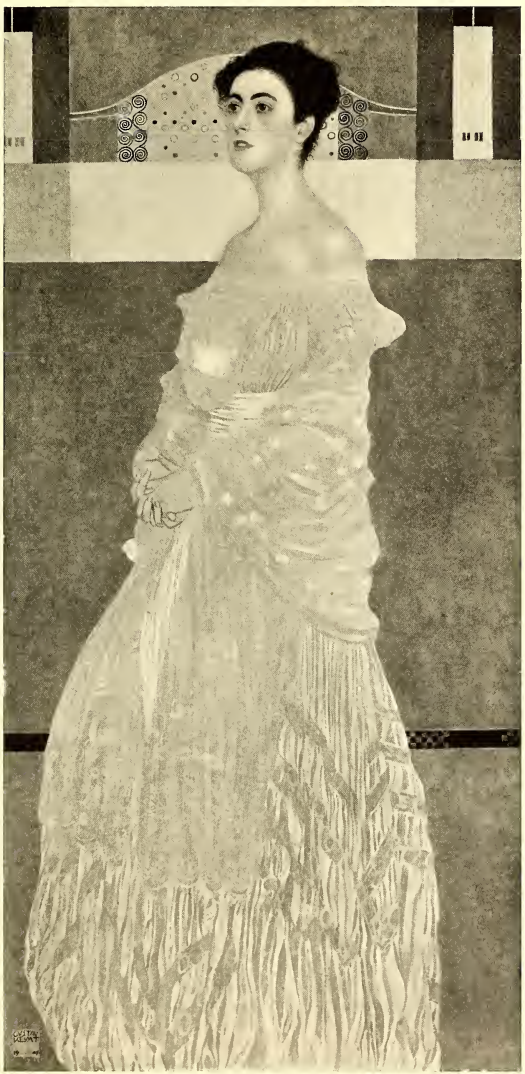

PORTRAIT OF A YOUNG LADY (BY PERMISSION OF THE MEITHKE FINE ARTS GALLERY, VIENNA) 


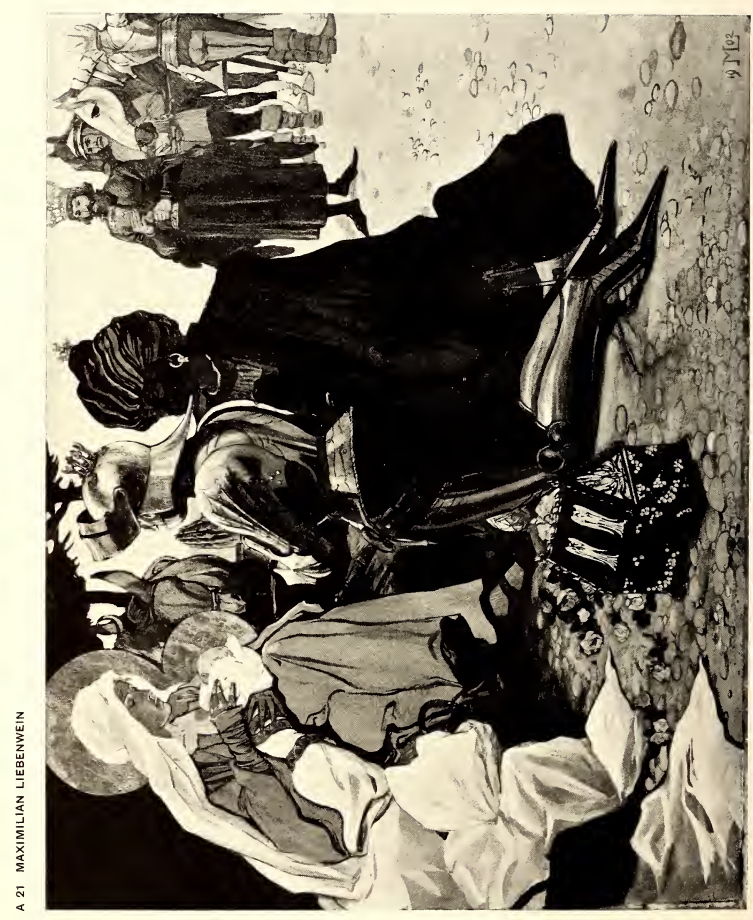

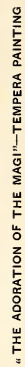




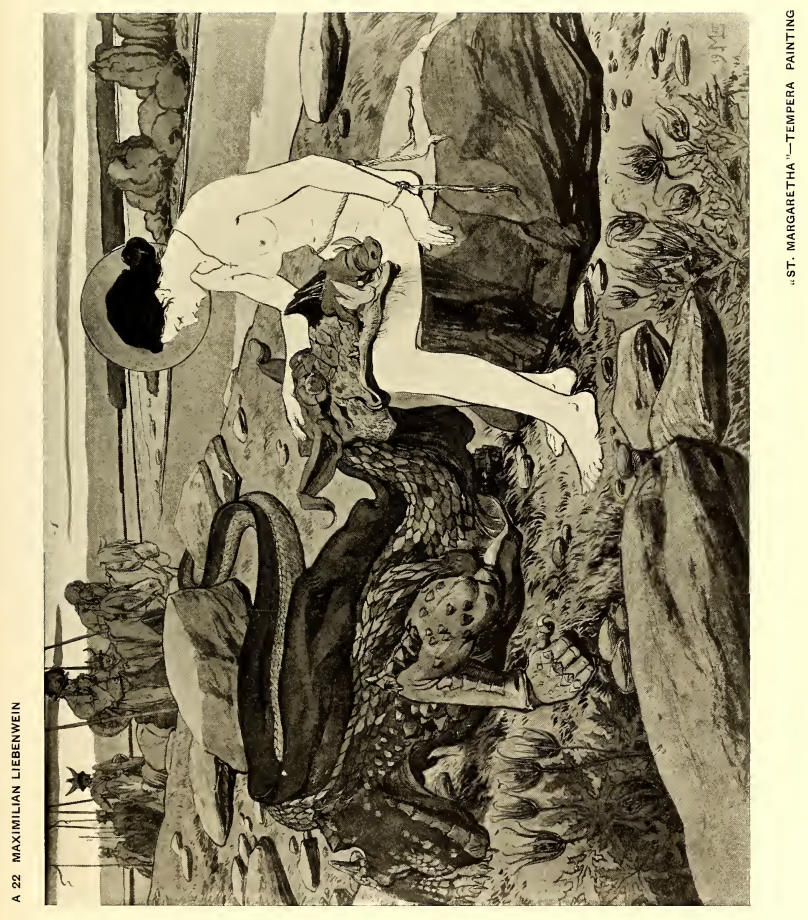




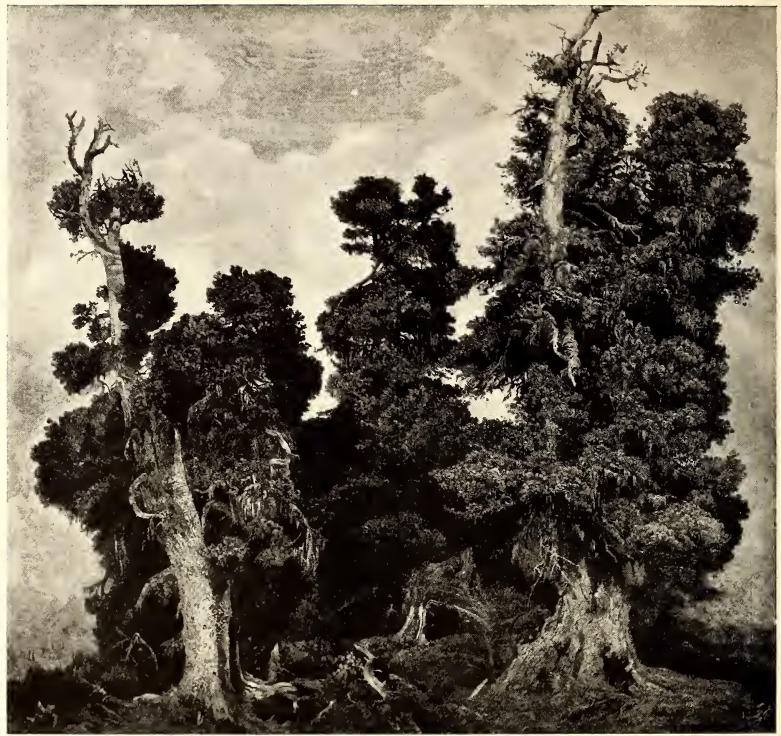




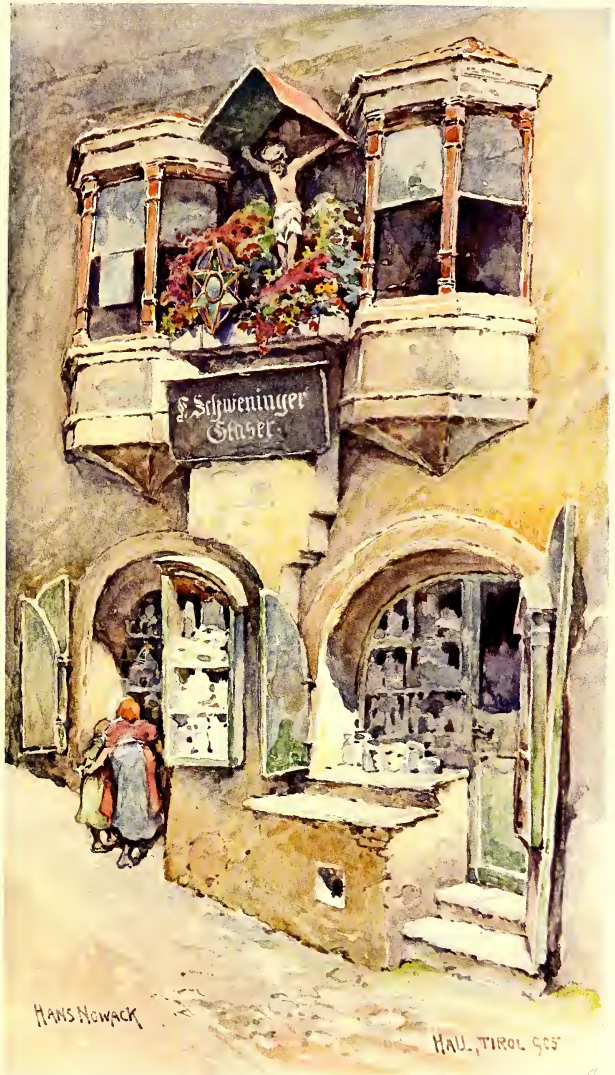





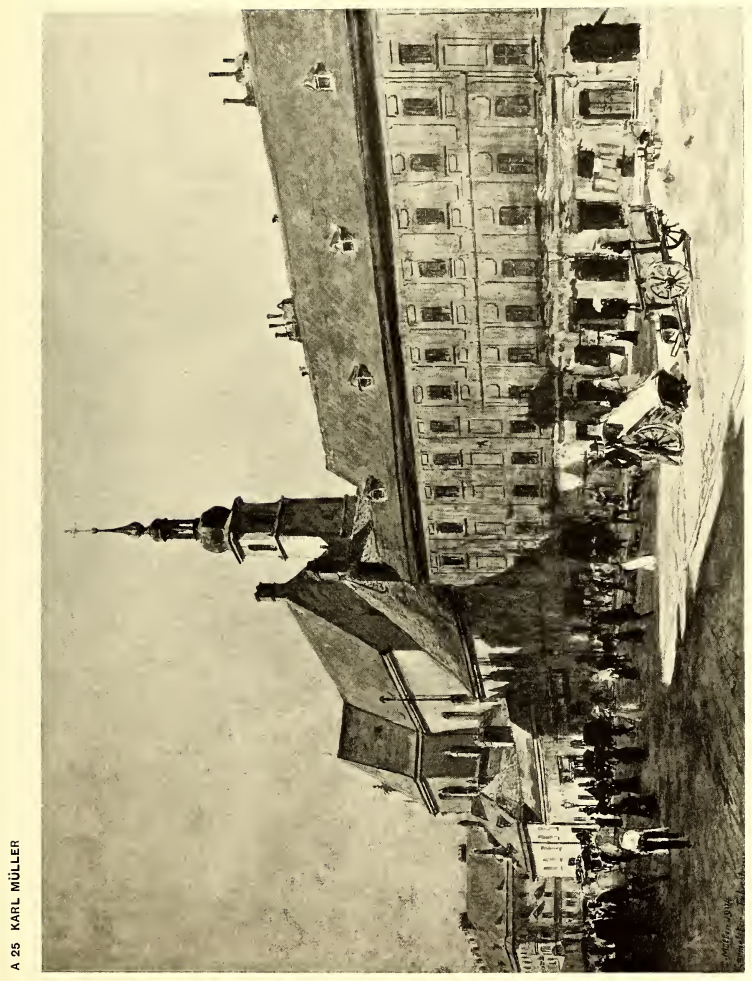




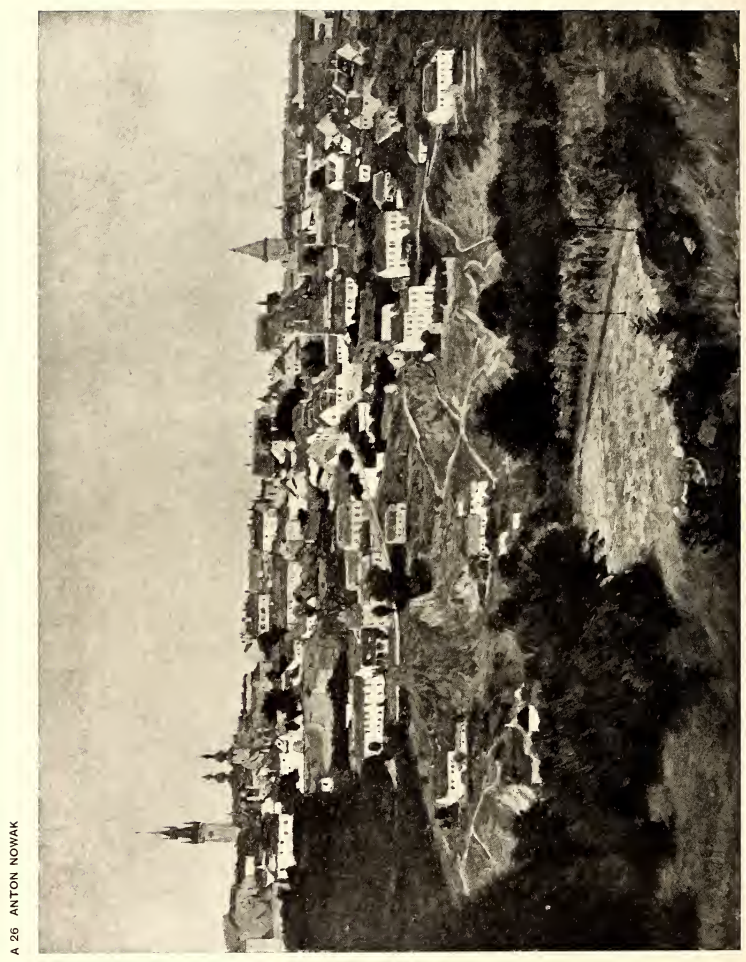

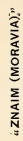




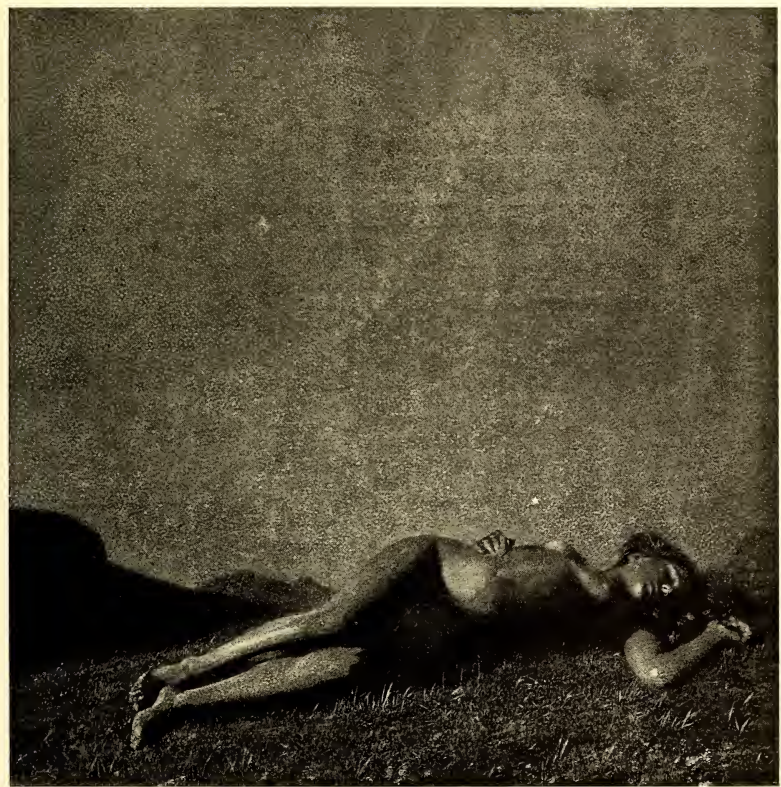




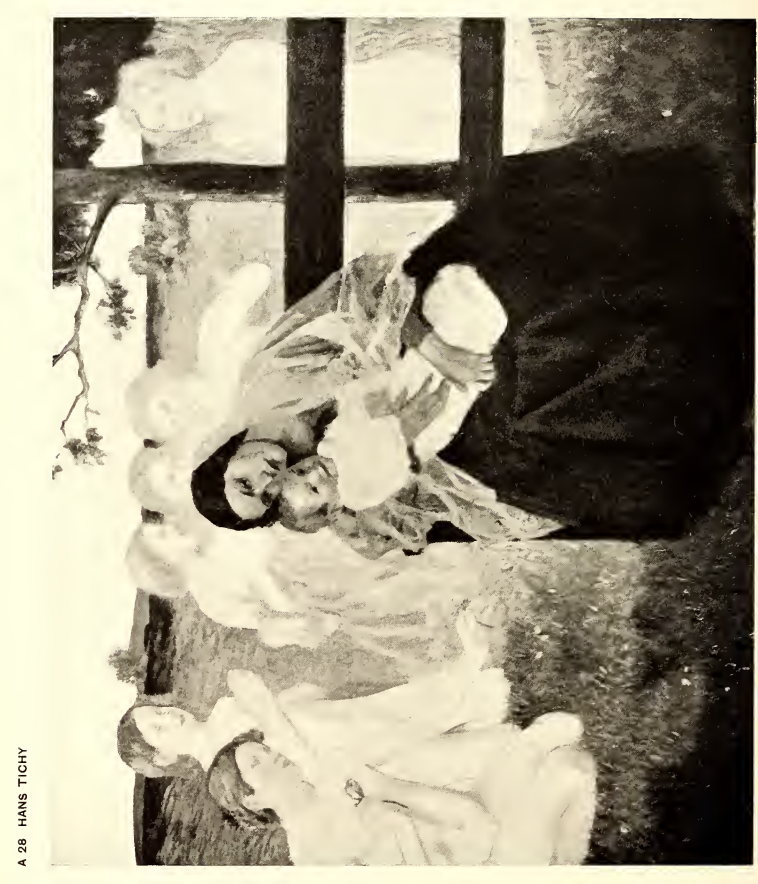

o
$\frac{0}{2}$
$\frac{\pi}{0}$
o
$=$ 


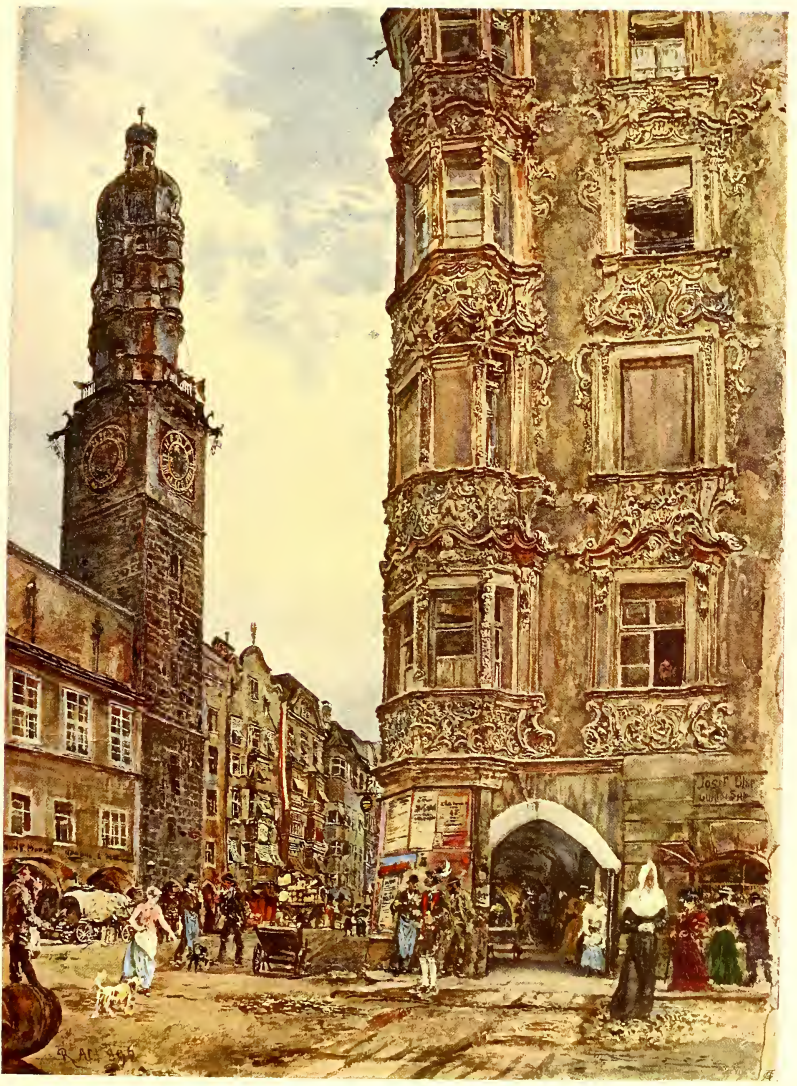



A 30 RUDOLF JETTMAR

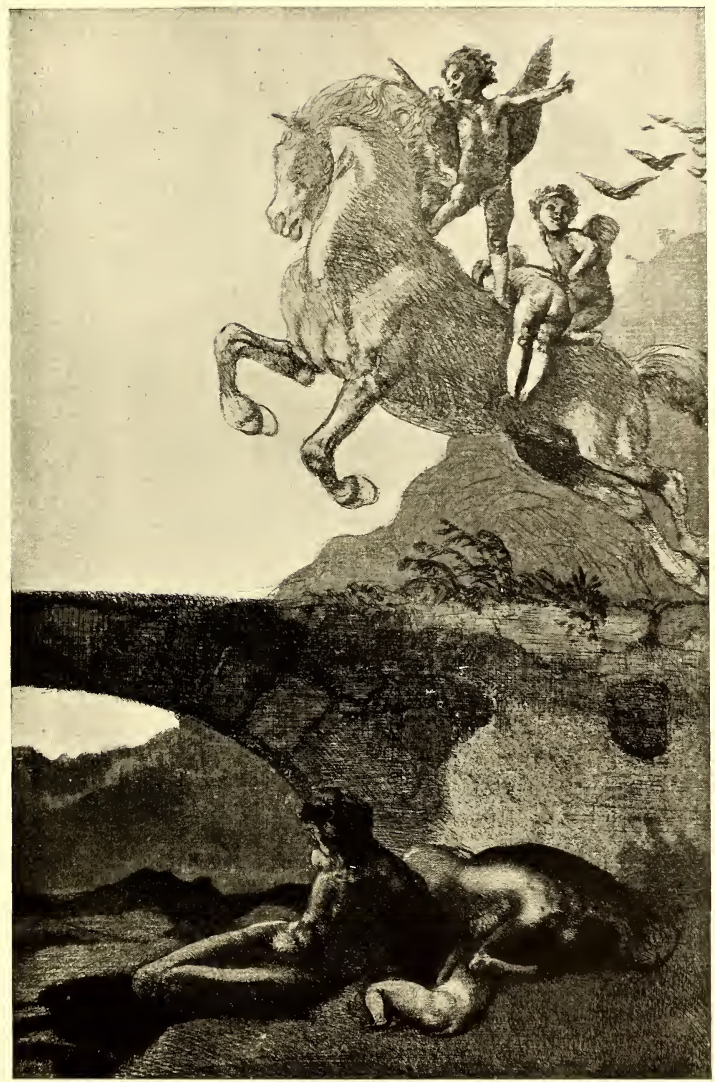

"SUNRISE."-FROM THE SERIES

OF ORIGINAL ETCHINGS “THE TWELVE HOURS OF, THE NIGHT" 


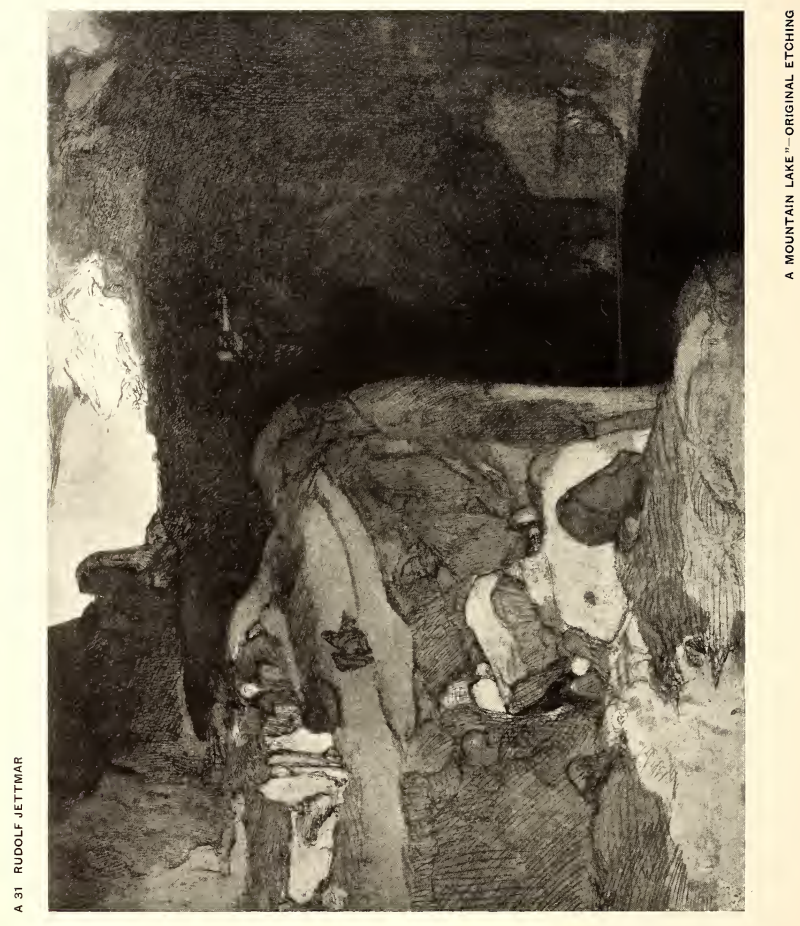


A 32 LUDWIG MICHALEK

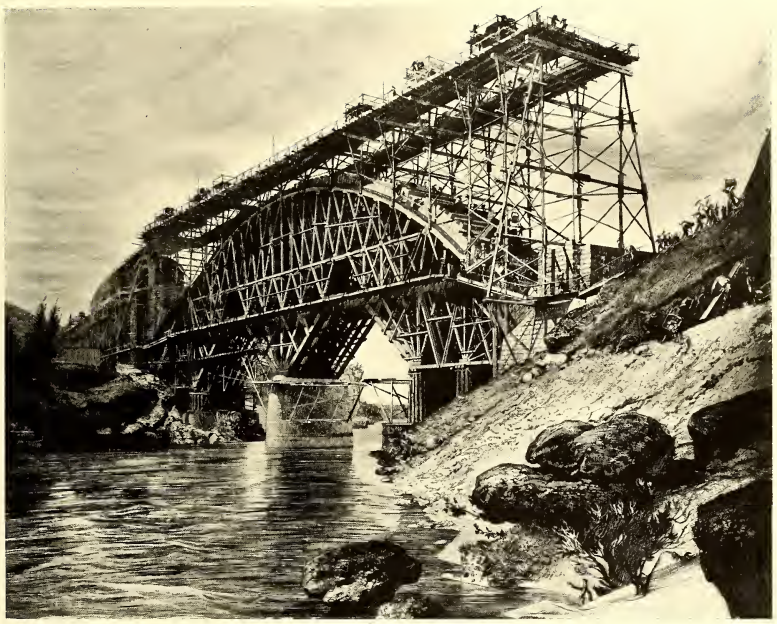




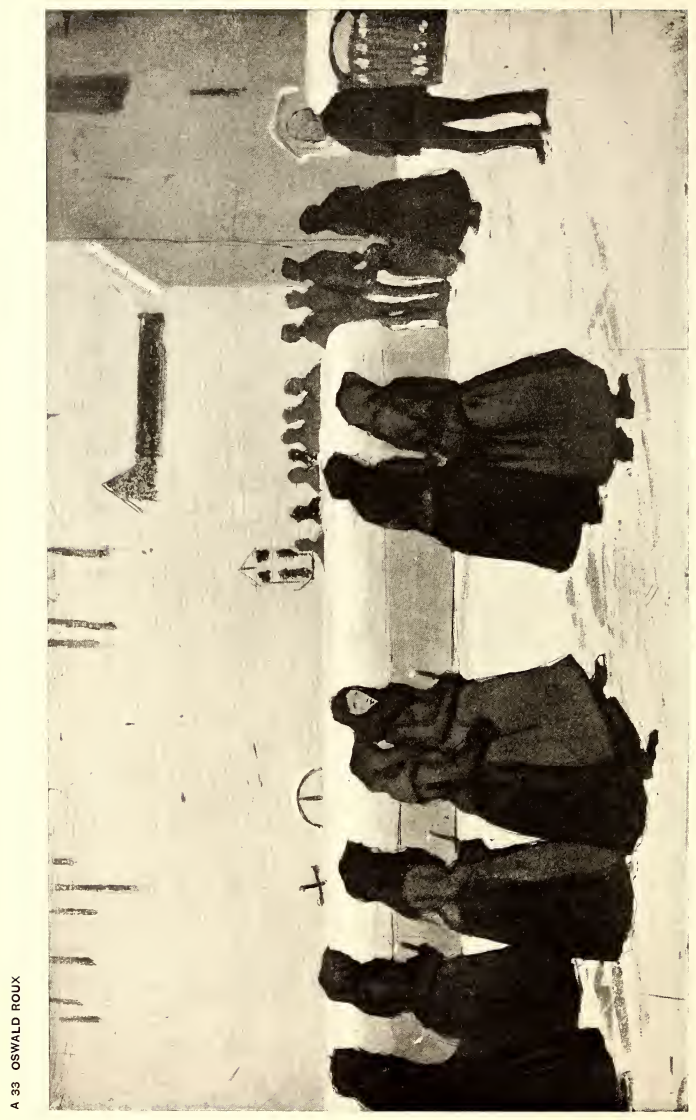

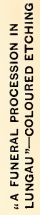


A 34 OSWALD ROUX.

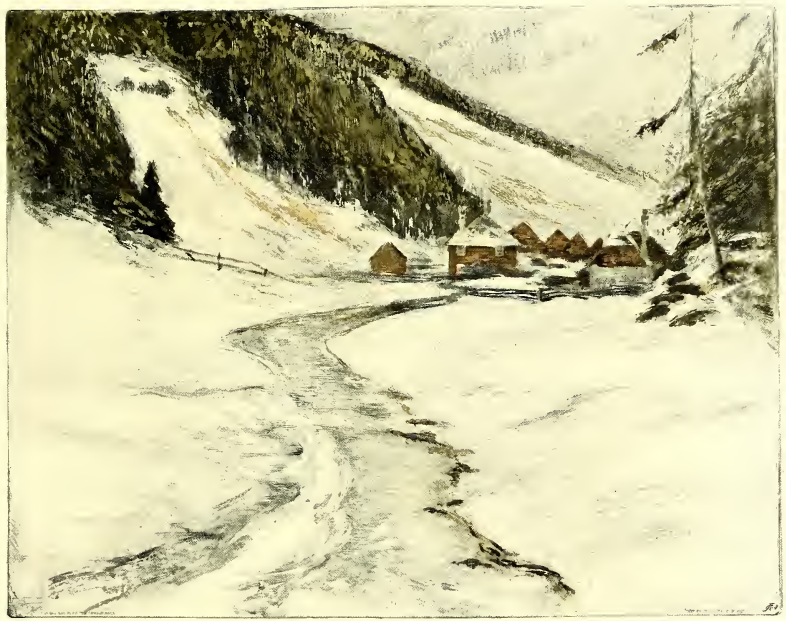





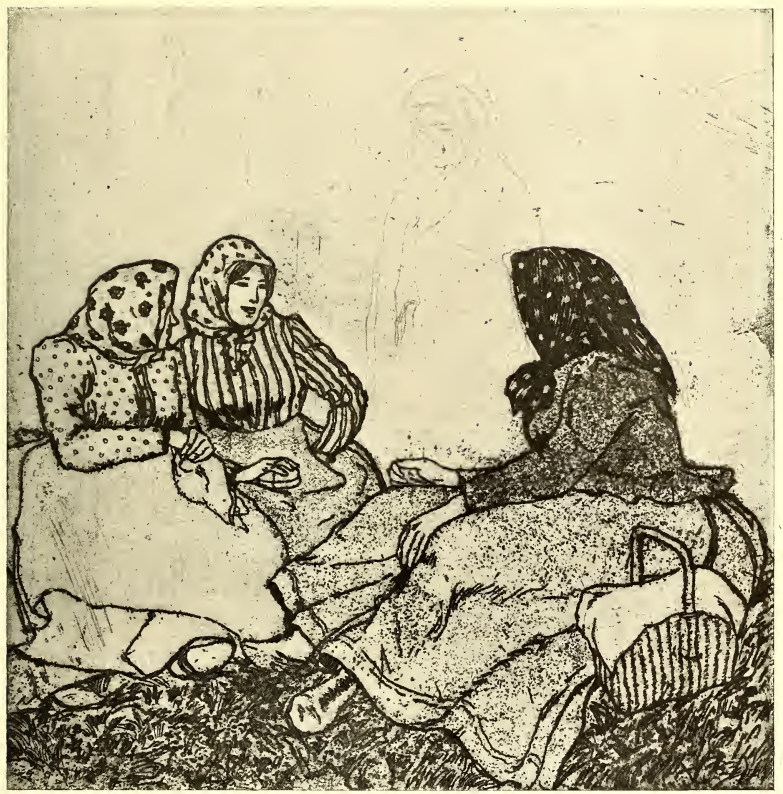




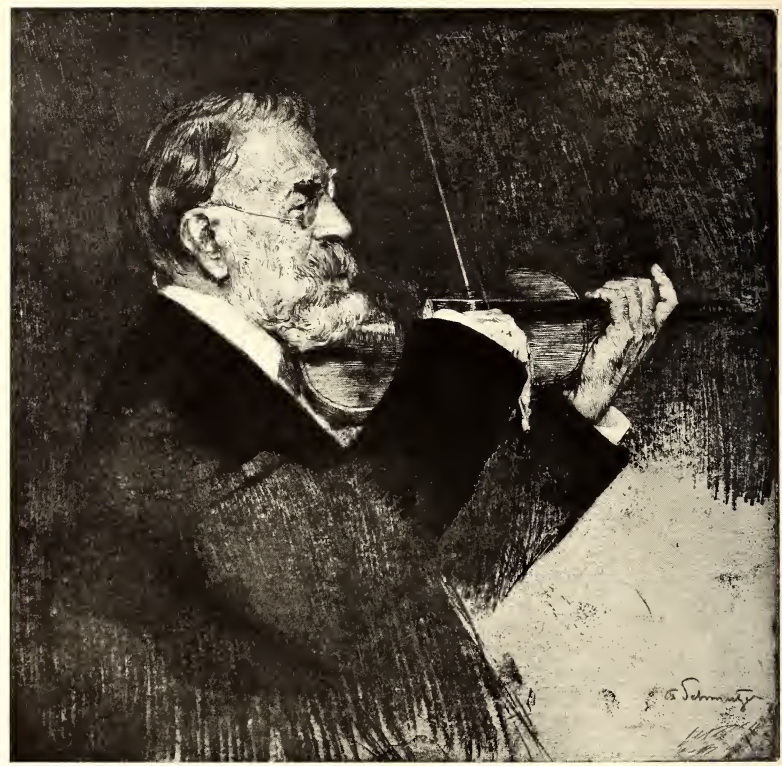




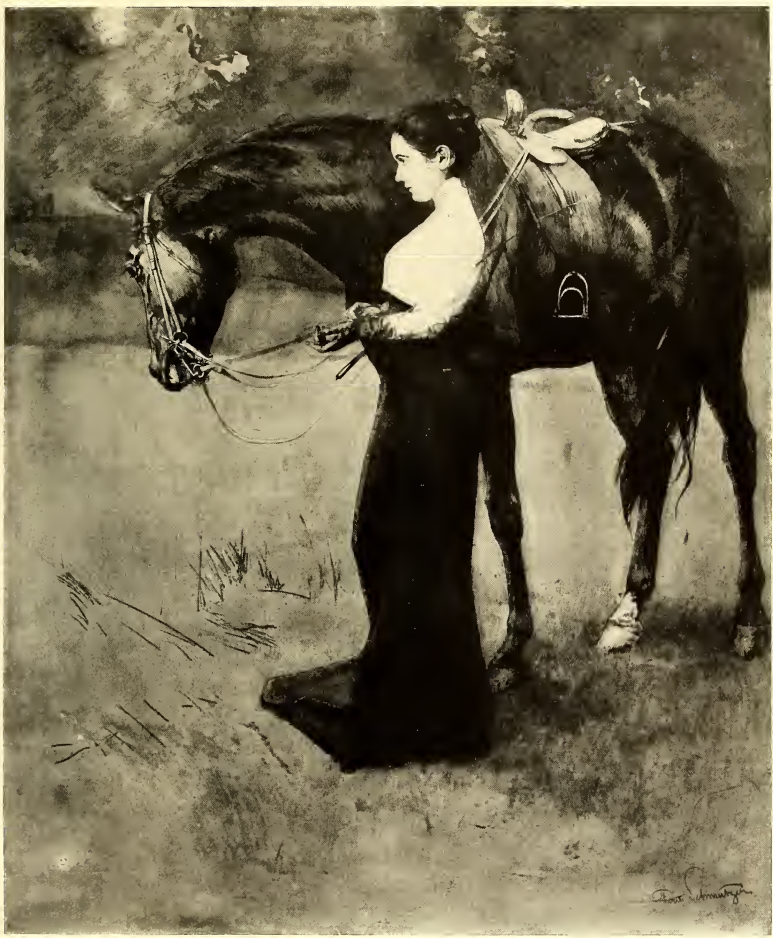




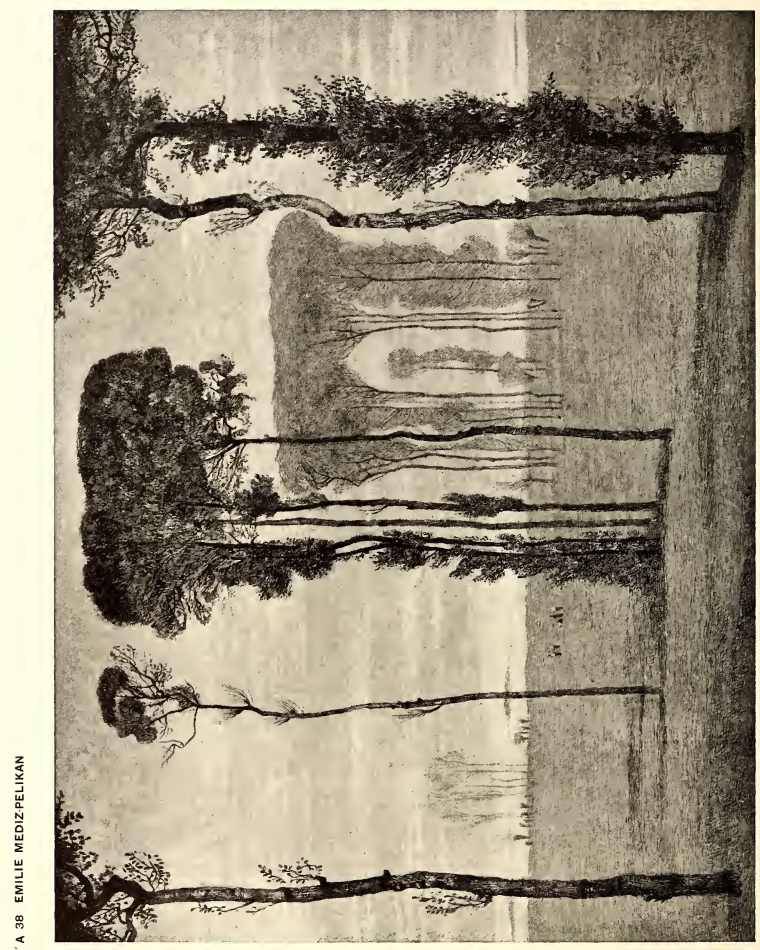




\section{MODERN PLASTIC WORK \\ IN AUSTRIA. BY HUGO \\ HABERFELD.}

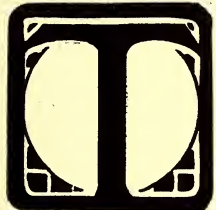

$\mathrm{HE}$ art work of nations is divided into two varieties: the "Kultisch"-or traditionaland the individual. Greek plastic work was for a long period traditional, the entire people, and not the few only, producing it. Artistic methods were as uniform as was the general view of life and the conventions of art were accepted just as unhesitatingly as was the inherited idea of the Deity. Art was a public matter, like religion and politics, and all personality was put aside. There was seldom any individuality in the workshop; there existed no artistic proletariat, because each force organically found its proper employment. So long as everything is surrounded by a single symmetrical idea, as in the case of Greek art up to the time of Praxiteles, or as in the Gothic art of Christianity, so long does traditional art predominate. Let this idea be shattered, however, and it vanishes, or else joins in alliance with the most heterogeneous abstractions, creating the most heterogeneous formations. Then begins individuality in art. And that individuality has now endured since the Renaissance. Just as one's outlook on life has expanded, so have the means of expression increased and multiplied. The individual creator stands in the forefront; his special characteristics, shared by none else, form his chief claim to recognition. The artist has withdrawn himself from the protection of the society around him, has lightly embarked on his calling with all its possibilities of happiness or tragedy; and beside him walks Mecænas, the patron.

It is but natural that in both epochs the arts should have developed diversely. The Grecian temples and the Gothic cathedrals were the colossal outcome of those national forces and aspirations which in wonderful, mysterious order expressed themselves in the might of their architecture, in the pathos of plastic art, and in the loveliness of colour. The kinship of the arts was never sundered ; from architecture sprang sculpture and painting, with new themes and new blossoms. Since the days of the Renaissance it has been otherwise. The monumental fresco has been superseded by the little 
easel-picture, and painting brought into its most fertile field of work. Yet standing alone there came into being a world of inexpressible beauty, which strove to attain a grace of subject and of method never reached in fresco painting. The severance of sculpture from architecture was most pernicious. Unlike painting, sculpture did not follow the new laws imposed by its separate existence, and thereby it escaped the great stream of development. Something alien, something cold, made itself apparent in most sculpture, and the quality of the work steadily depreciated.

While throughout Europe during the nineteenth century the opportunities for a revival of plastic art were altogether unfavourable, things were no better in Vienna. Our greatest sculptor of bygone days, the highly-gifted Georg Rafael Donner (I693-I74I), came from a school of sculpture imbued with high traditions, yet he had no worthy successors; and thus the glorious period of the Viennese baroque style reached in him at once its highest development and its end. The sculptors of the first half of the nineteenth century were either bound fast to the stiff forms of academic classicism, or had lost themselves in trivial genre work of the "Empire-biscuit" type, which had no connection with sculpture, but was rather an offshoot of the truly delightful Old Viennese porcelain work. About the middle of the century there came with Anton Fernkorn (18 I $3-1878$ ) a strong infusion of the North German influence into Viennese plastic work, and this was further emphasised later by Caspar v. Zumbusch, who was born in 1830 . The works of these two sculptors are marked by the same strongly-developed influence of the bronze-cast technique, and by a certain monumental effort, produced not so much by heroic conception or form as by the colossal disposal or their material, which ever seems to dominate its surroundings. Beside these "immigrants" there arose a group of Viennese sculptors. These were few in number; indeed it has been estimated that of two hundred Austrian artists who took part in the Paris Exhibition of 1867 only two were sculptors. Interest in sculpture was at that time very slight in Vienna, and it was left for artists of a later date, artists more fully qualified, to increase that interest. In this remark I of course except Karl Kundmann (born in $18{ }_{3} 8$ ), Rudolf Weyr (born in 1847), and particularly Victor Tilgner (1844-1896), so thoroughly Viennese, and full of talent. The public, who, since the colour-craze of the Makart period, had developed a fashion for visiting art exhibitions and studios, still regarded plastic work with a lukewarm attention; and even to-day, when painting and applied art are of world-wide importance, B ii 
sculpture is still more or less neglected, and does not occupy by any means its proper place. But meanwhile appreciation of this most noble of arts is growing with increased knowledge, and perhaps the twentieth century may be spoken of some day as "the Sculptors'" century, just as the nineteenth is styled "the Painters'." The most recent revolution in Viennese art, which came about with the foundation of the "Secession" in the spring of 1897 , had a less favourable effect on sculpture than on painting. The young generation of painters and applied art workers had produced many brilliant works, whereas only a few isolated successes had been scored in sculpture; and, apart from that, the painters had a great advantage Throughout the nineteenth century there had been a regular, historically-evolved succession of Austrian painters, the list beginning with Ferdinand Georg Waldmüller, and including Theodora v. Hörmann as a representative of the modern spirit. To such as these our young artists could always turn for inspiration when in danger of being too much diverted by foreign models and influences. In the domain of plastic work the only tradition of this sort is that of the Viennese medal. Its real founder was Josef Daniel Böhm (I794-I 865), a delicate "Romantiker," who was inspired by antique and religious art. A pupil of his was the somewhat prosaic Karl Radnitzky (1818-1903), who in turn became the master of Joseph Tautenhayn (born in I 837), an artist of great fertility of composition, and of the talented student of character, Anton Scharff (1845-1903). It is interesting to note that Scharff was commissioned by the City of London to execute a medal of Queen Victoria. There proceeded from the School of Tautenhayn, who was a professor at the Academy, and from the School of Scharff, who was director of the Engraving School of the Mint, a number of talented medallists : Rudolf Marschall (born in 1873), chiefly known by his plaquettes and his medals of Kaiser Franz Josef I. and Pope Leo XIII.; then Franz X. Pawlik (born in 1865), Joser Tautenhayn, Junr. (1868), Peter Breithut (1869), and Ludwig Hujer (1870).

Austrian plastic work on a large scale, however, boasts no fruitful tradition, such as painting and medalling possess. Every prominent sculptor with us has always been an individual apart, an exception. We have never had a school whereby or wherefrom a number of artists guided towards a common ideal might be produced. The evil result of this has been that all our young sculptors alike have had to rely solely upon themselves. It had, however, this advantage, that there was no such embittered struggle 
among the sculptors as with the painters; moreover, certain artists of the older generation being, as it were, isolated and absolutely independent, found themselves able to join in the new movement.

Among those of our sculptors to-day who may be described as being in the full bloom of their knowledge, is Edmund Hellmer (born in I 850 ), whose artistic character reveals a remarkable inconsistency. On the one hand, Hellmer possesses the delicate grace and the light-heartedness of the Viennese spirit; on the other, we see a sour hypercritic, never satisfied with what he has done, who, to make his work still better, regards it ever from a more minute, a more captious standpoint. Thus he is a most elaborate finisher, never knowing when to leave his work alone, but pottering over needless emendations until nearly all the charm and spontaneity have been lost. How he began may be seen in the monumental group on the roof of the Parliament House, representing Kaiser Franz Josef I. granting the Constitution. Here the academic spirit is mingled with a want of selfdependence, which shows itself in too close a suggestion of certain antique compositions of the same style, the result being that the work has a rather stiff appearance. In the same way his second big work, the Turkish memorial erected in $188_{3}$ in St. Stephen's Cathedral, although it reveals more freedom of treatment, yet it makes no "monumental" impression on the beholder, and connects its creator with the group of men who follow in the train of Count Starhemberg, the artistic Liberator of Vienna. So, too, his later composition, Oesterreichs Landmacht, which stands in a niche in the castellated façade, is not very satisfying, for while it is, in point of positive skill, far above the pendant group Oesterreichs Seemacht by Weyr, it is greatly inferior thereto in temperament and vivacity. Finally, his last monumental work, the Castalia-Brunnen, for the courtyard of the University, is excellent plastically, but its rather unfortunate architecture weakens the effect. By the nature of his gifts Hellmer is most " at home" with the single-figure memorial, wherein he contrives to put all that is best in him. Here we have a memorial of the landscapist, Emil Jakob Schindler, depicted in tourist costume, reposing on a rock; and then the Goethe monument in the Ringstrasse, where, not only as a great poet, but as a great man, the figure is seen seated in a fauteuil; and, lastly, the graceful statue of the immortal Empress Elisabeth at Salzburg, and a tombstone relief for the grave of Hugo Wolf. It should be mentioned that Hellmer is a professor at the Academy, and a famous teacher. From $B$ iv 
his school came Therese Feodorowna Ries, and at the most recent exhibitions there came into prominence such talented and highly promising pupils as Hugo Kühnelt, Anton Hanak, Franz Ehrenhöfer, and Alfred Hofmann.

The second artist of the older generation to fall in with the modern spirit and to meet with a right hearty welcome was Arthur Strasser, who was born in 1854 . As a sculptor he belongs to a school which in painting has won many triumphs-namely the Oriental; and his work forms, as it were, a plastic pendant to that of the late Leopold Karl Müller, the well-known painter of Eastern subjects, who died in 1892 . His best things are Japanese, Egyptian and Indian genre paintings, in which he displays remarkable skill in depicting racial characteristics and animal nature, combined with a strong sense of colour. It is easy to understand that he revelled in Makart. When Strasser joined the "Secession" his knowledge increased, and whereas formerly he had been chiefly occupied with small bits of sculpture, he soon began to devote himself to life-size monumental groups, such as his Mark Antony, who rides in triumph in a car drawn by lions, or his Amazon Queen Myrina, who in grotesque embonpoint sits on a throne of stone, holding two tigers chained, and with knitted brow looks darkly down. For some time past Strasser has been a professor at the "Kunstgewerbe-Schule" (School of Applied Art), and one rarely sees any work by him nowadays.

The rest of the older men among our sculptors have not fallen in with the new movement; but for the most part have remained attached to the old association, the "Künstlergenossenschaft." None of them approach Hellmer or Strasser in importance, yet some there are who deserve to be mentioned.

Hans Scherpe (born in 1855 ) is a popular memorial sculptor, whose Anzengruber is much admired by the uncritical portion of Vienna. The poet is represented as pausing during a walk on a cliff, at the foot of which stands the Steinklopferhans, Anzengruber's finest character, breaking stones. Hans Bitterlich (born in I 860), a skilful craftsman, is now completing the figure in the memorial to the Empress Elizabeth. The architectural portion of the work was done by the "Oberbaurat," Ohmann. Last year Carl Wollek completed a Mozartbrunnen, the group, Tamino and Pamina being sympathetically treated in a flow of melodious lines. Josef Kassin (born in $185^{6}$ ) came to the front with his group of a sick girl and her nurse, commissioned by the Rothschild Hospital. By Hans Rathausky (born in $185^{8}$ ) we have a good memorial of Adalbert Stifter, the poet; by Franz Seiffert, the figure portion of 
the Strauss-Lanner memorial, the highly effective architecture of which was designed by Robert Örley; and finally should be mentioned the distinguished wood-carver, Franz Zelezny, and his rival, Franz Barwig, whose works show all the severity proper to the material employed.

As I have already said, plastic art played but a small part in the events following the establishment of the "Secession" in Vienna. And the meaning of my remarks will be easily understood when it is realised how few sculptors are to be found among the members of the two artists' associations. To the "Secession" there still belong two sculptors. I am, of course, not thinking here of Hellmer, already in high esteem, or of the highlygifted Hugo Lederer, who is essentially Austrian, although he has lived for some years in Germany, where he has executed several notable commissions, including the Bismarck memorial for Hamburg and the University fountain at Breslau. The first of the two sculptors just referred to is Alfonso Canciani (born in $186_{3}$ ), whose design for a Dante memorial (the poet, standing on the edge of a precipice, beholding the torments of the damned) attracted considerable attention, although the composition as a whole is conceived rather from the painter's than from the sculptor's standpoint. The second of the two is Othmar Schimkowitz (born in 1860 ). $\mathrm{He}$ worked for a long period in America with Karl Bitter, a native of Vienna and a pupil of Hellmer's. Among the various works that have brought his name into prominence are the Astor memorial doors for Trinity Church, New York, and the equestrian statue of Washington. On his return to Europe, Schimkowitz attracted attention by his share in the Gutenberg memorial, in which he collaborated with Plecnik, the architect; but since then, with the exception of an excellent memorial tomb, he has produced nothing of similar merit. The "Hagenbund" boasts five sculptors among its members. Mention has already been made of Barwig, the woodcarver. Gustav Gurschner (born in 1873) shows great taste in his small pieces, but he is somewhat inclined to mannerism, and his applied art surroundings and connections cause his work to smack rather too strongly of pure-and therefore not always of novel-decorative effects. Joseph Heu and Theodor Stundl are two young sculptors of all-round capacity and much promise, good both in portraits and in figure compositions, but as yet undeveloped and just at the start of their careers. The most original member of the little group is, undoubtedly, Wilhelm Hejda (born in 1868), painter and sculptor; but as yet he has not fulfilled his promise of the savage B vi 


\section{MODERN PLASTIC WORK IN AUSTRIA}

genius which marked the work of his early years-the savagery alone has remained and that has overstepped the bounds of art and of technique. As a colourist he is outré, yet he occasionally obtains the happiest effects. So too his sculpture, which inclines towards the horrible, is, as it were, bedaubed. Among the best of his most unequal works is the coloured colossal relief in yellow, green, gold and glass cabochon on the façade of the "Hagenbund." It represents Pallas Athene protecting the Arts, while the people pay homage to the goddess.

Of the artists who at present are attached to no association must first be named Richard Luksch (born in 1872 ), who retired from the "Secession" with the Klimt group. He combines a sure mastery of form with great fancifulness of vision. Of this quality there is a good example in his oak-carved Wanderer, a naked man, of life size, striding over rough ground, whence, with each pace, spring up on every side forms human and animal, symbolical of the creatures and the ideals which he, in the course of his life, has ruthlessly trodden down. Luksch has recently produced much good decorative plastic work for buildings of the Wagner and Hoffmann style. His wife is the daughter of the Russian painter Makowsky, Elena Luksch-Makowsky, an extraordinarily talented artist both as painter and sculptor, not only showing genius in the daring of her conceptions, but also creating from sheer love of the beautiful. The only woman sculptor to be compared with her is Elsa v. Kalmar. She commenced as a painter, but, turning later to her more decided gift of sculpture, studied in Munich, and then for two years in Florence, in order to learn of the old masters. Mention should also be made of Joseph Müllner, who is still attempting colossal figures, and who ought to develop into one of our most refined plastic workers.

The Czechs have given to the world a number of sculptors. Even before the modern movement there appeared a sculptor of note, Joseph von Mylsbek (born in I 848), a plastic artist of truly monumental greatness, imbued with historical feeling, not acquired, but innate in his heroic nature. Although an Academy Professor in Prague he has no direct following, since all the younger school treads a path widely removed from his, with the exception of one, the eldest amongst them, Stanislav Sucharda (born in 1866). Beginning as Mylsbek's pupil, Sucharda continued to work for some considerable time in his manner, only later turning his mind to that form of plastic art which is to be found in the still unfinished Palacky monument. His portraits of children are especially remarkable. 
Possessing a similar style, Frantisek Bilek (born in I 872), displays something of the primitive but expressive Gothic manner, something of the painfully realistic naturalism of those most religious artists. A truer exponent of sheer form is Ladislav Saloun, who does portrait figures of ladies in full dress in the style of Carabin or Troubetzkoi, and gives us a powerful example of his art in the Huss monument. Joseph Maratka, who worked for many years under Rodin, has produced exquisite female busts and statues. And there is also Bohumil Kafka, who has already done good work in portraiture, and shows still greater promise.

We now have to render homage to a sculptor who belongs to none of the afore-named categories. The art of Franz Metzner is chiefly characterised by the fact that he strives to prove that the historical development of plastic art, as I have sought to demonstrate in the opening of this article, has its issues in its close alliance with architecture. What he desires is a blending of architecture and plastic art, in which the plastic work should appear as a flower sprung from the architectural soil. By architecture Metzner does not understand a mere building for practical uses, nor even a purely ornamental construction. $\mathrm{He}$ would have mighty temples, halls, mausoleums, the stately art of pure form, the harmony of great lines, free from petty detail, the beauty of stone heaped upon stone. Such is also his plastic work; not a copy, but a symbolic representation of life and nature, a simplification of form rather than a striving after variety of characteristics and expression. And in the same degree as his architecture and sculptures are of heroic proportions, so is the spiritual side of his work a search after the great forces which govern our existence and rule our lives.

Metzner has designed a memorial statue of Richard Wagner in Berlin and a model for the Empress Elizabeth memorial. $\mathrm{He}$ also created a design for a Nibelung fountain which was to have been erected in front of the Vienna Votiv-Kirche. He is working at present on a monument of Stelzhamer for Linz, the capital of Upper Austria, a fountain for Reichenberg, an Emperor Joseph memorial for Teplitz, and a Mozart memorial for Prague. Metzner accepted with pride the commission of Bruno Schmitz, the gifted creator of the "Völkerschlacht" memorial in Leipzig, for the entire decoration of this monument. Austrian sculpture is thus honoured in this young master, and he is undoubtedly its greatest hope to-day. 


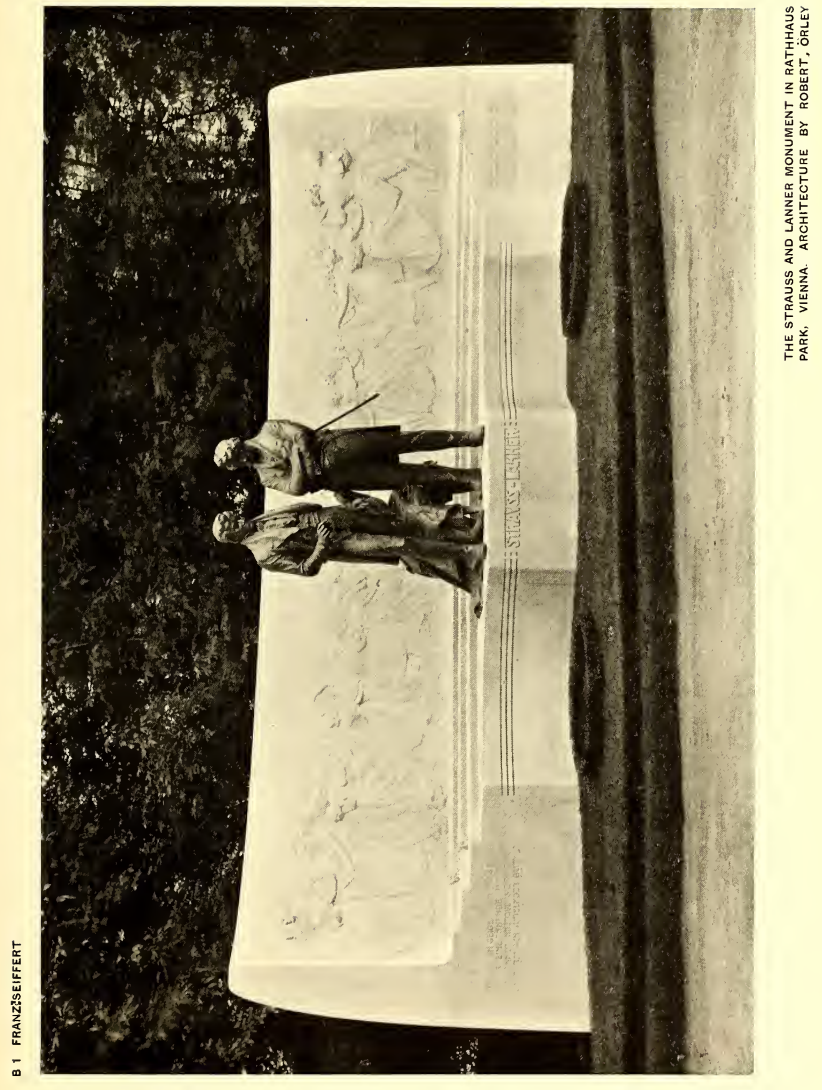




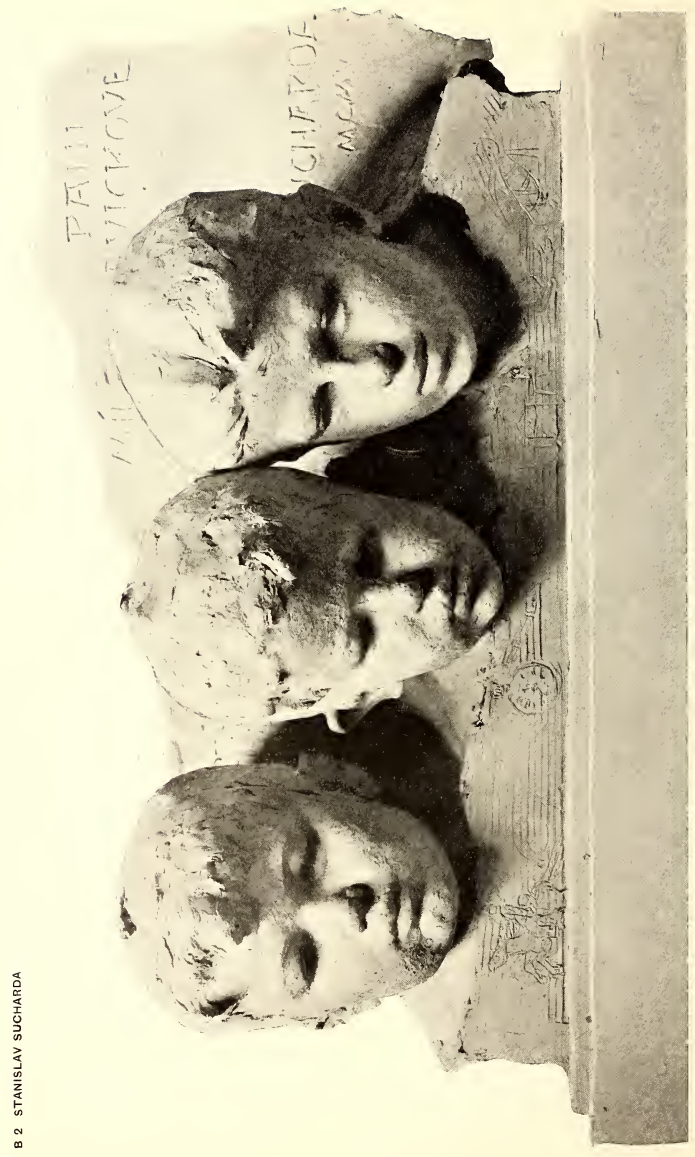

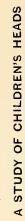



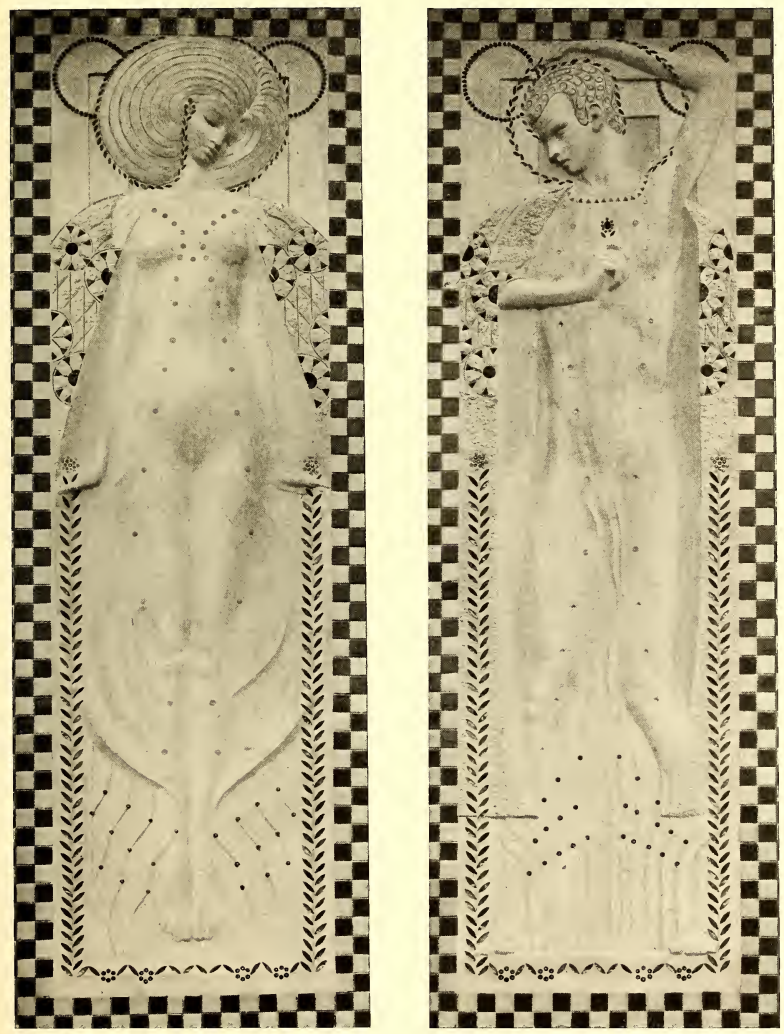

RELIEFS ON THE FACADE OF THE 
B 5 JOSEF ENGELHART

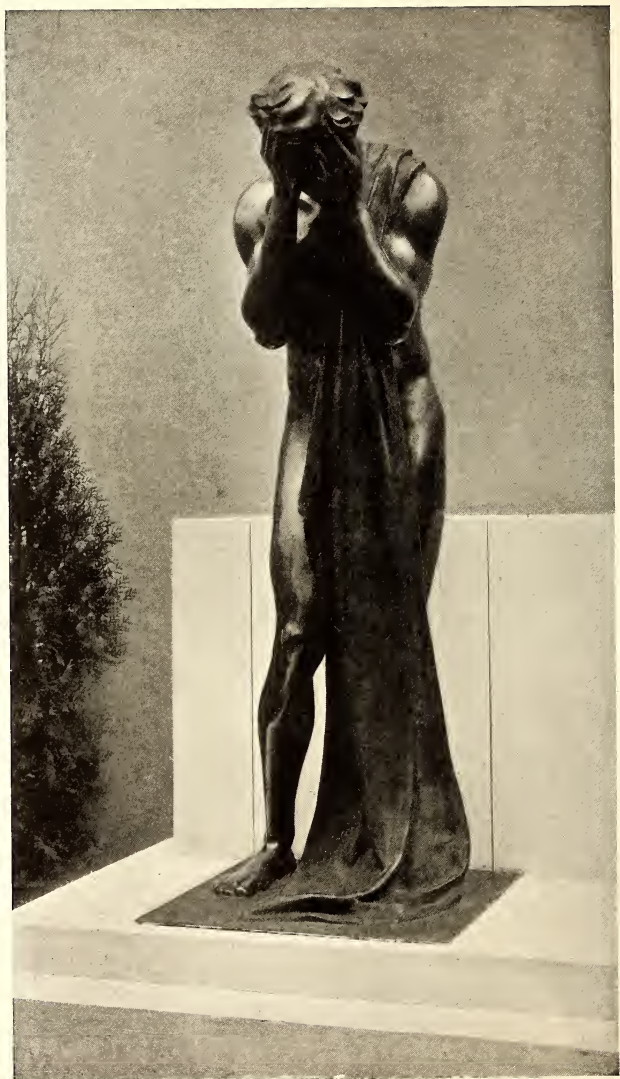

FIGURE FOR A TOMB

STONE-BRONZE 


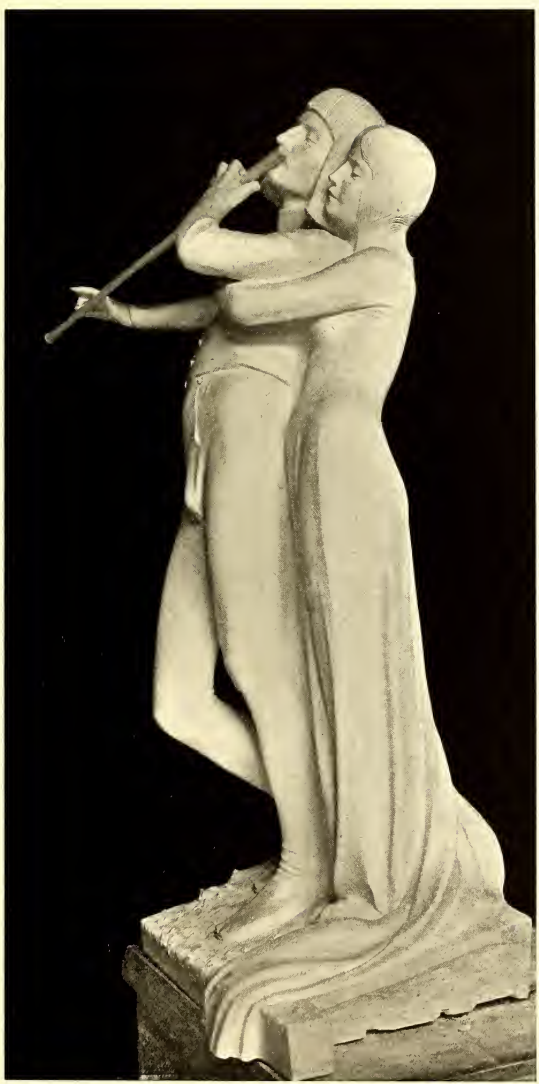

TAMINO AND PAMINA"-PORTION OF THE MOZART FOUNTAIN AT VIENNA 
B 7 HUGO KÜHNELT

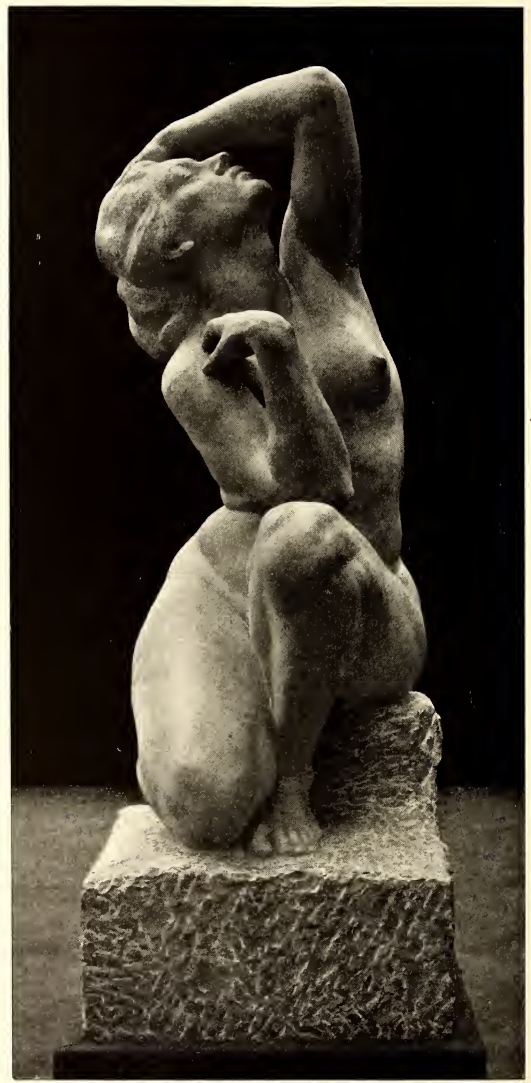




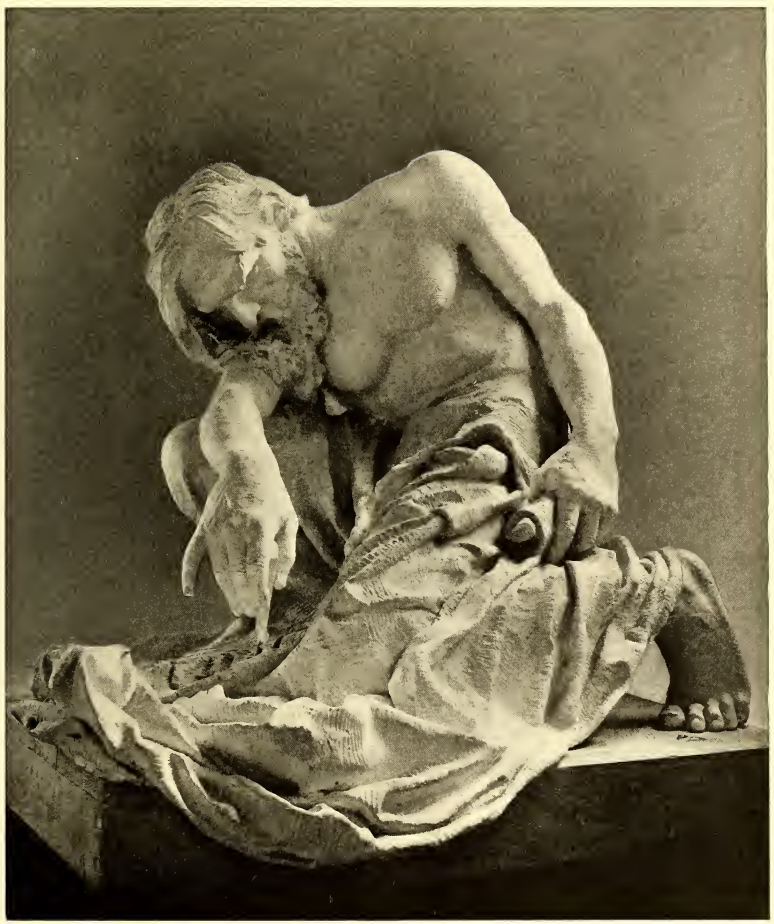




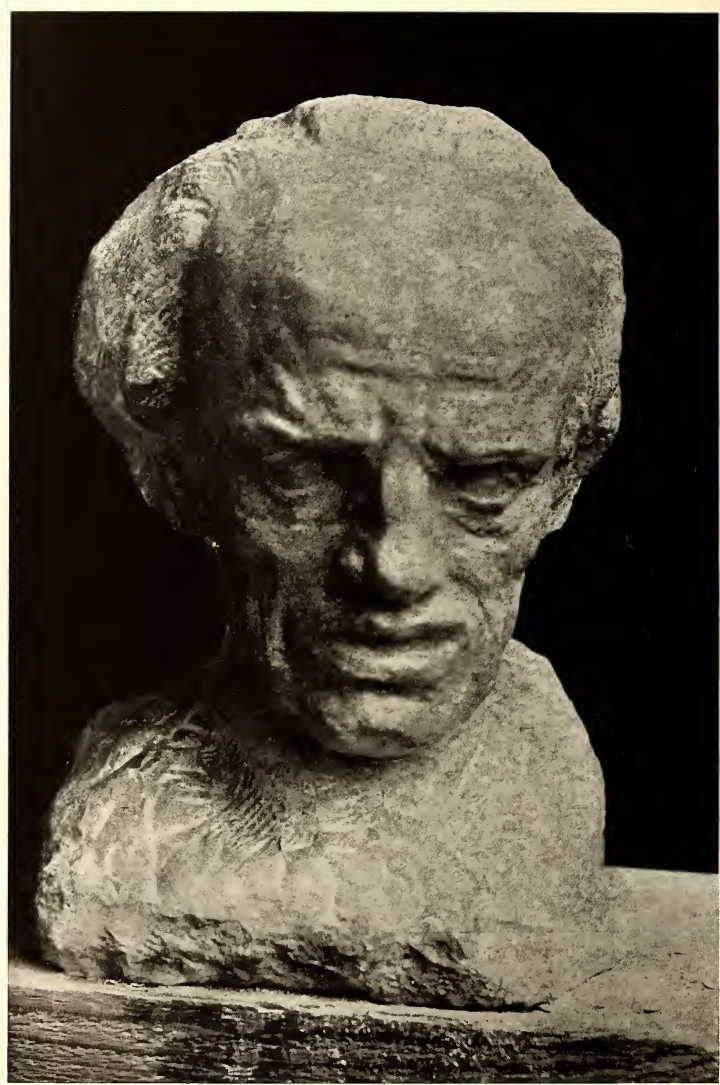




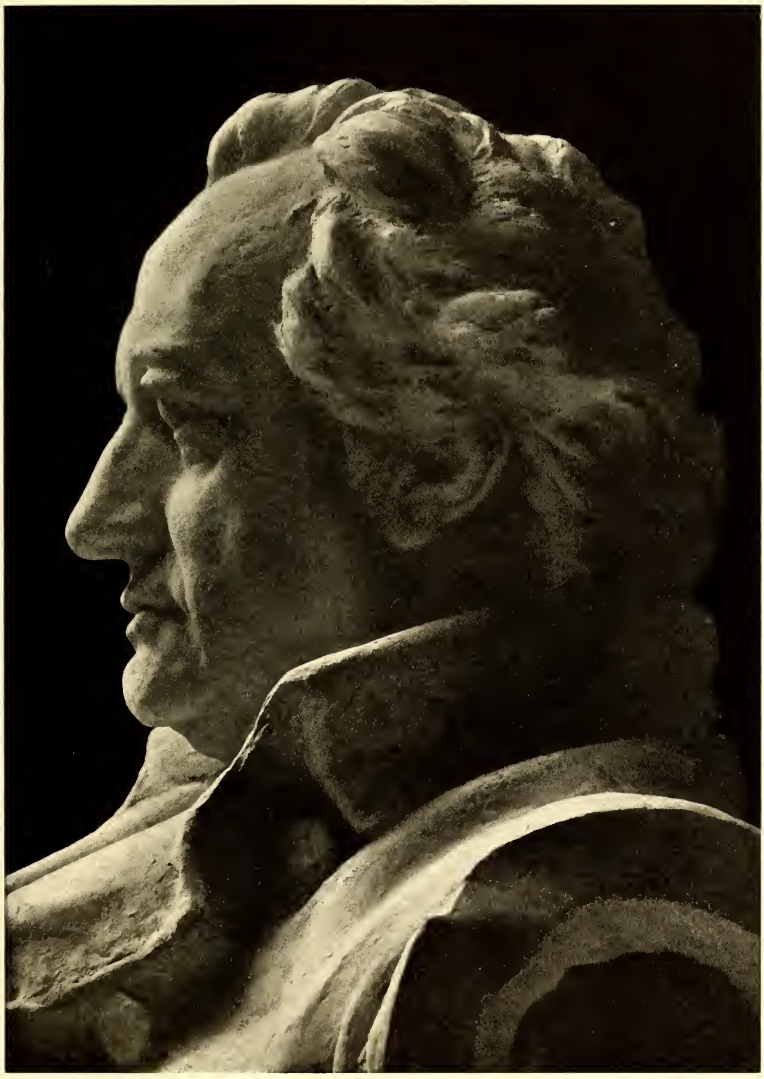

STUDY FOR THE GOETHE MONUMENT IN VIENNA 


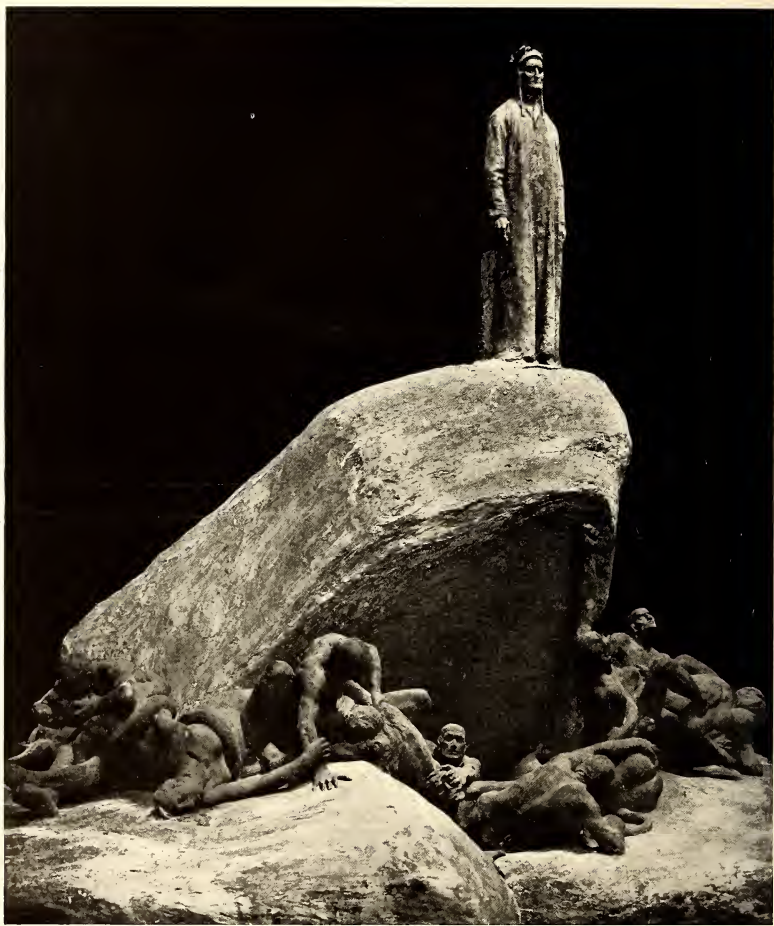




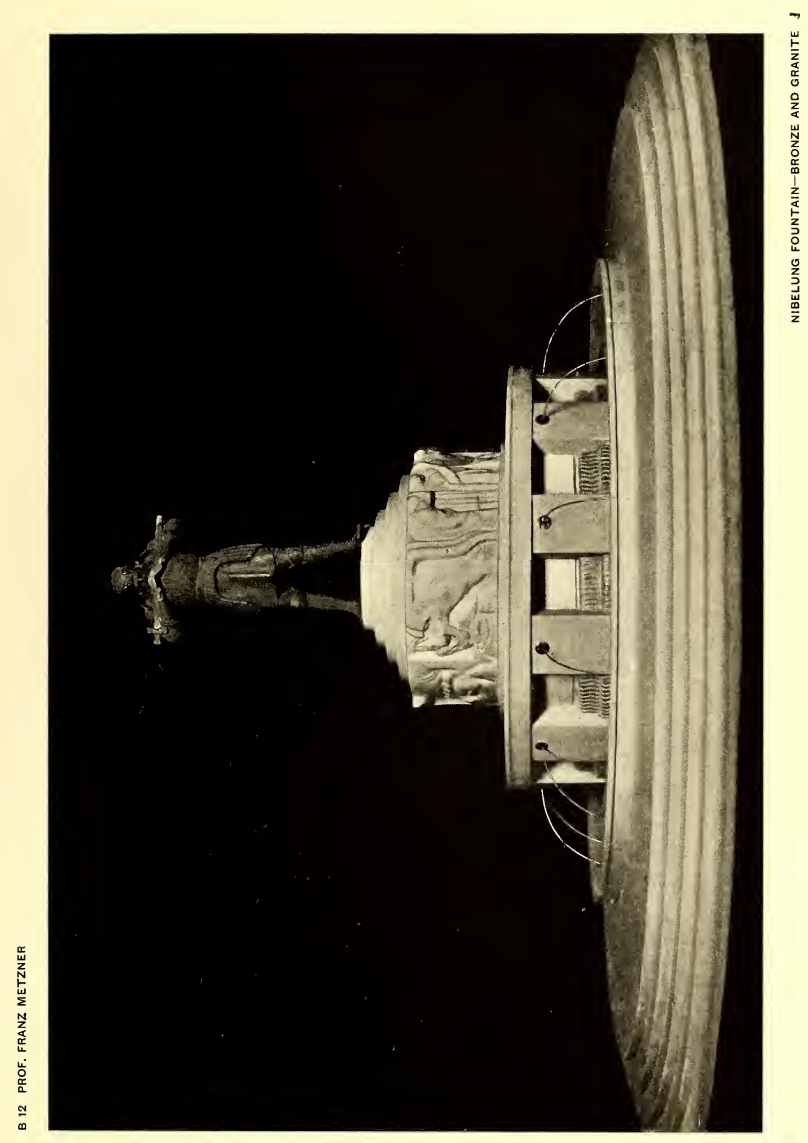




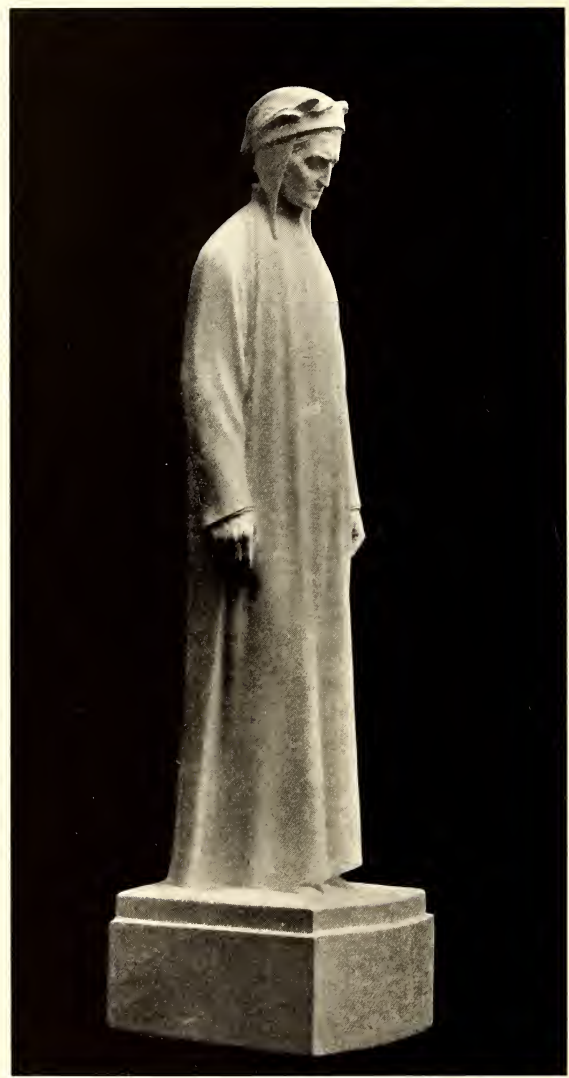

DANTE 

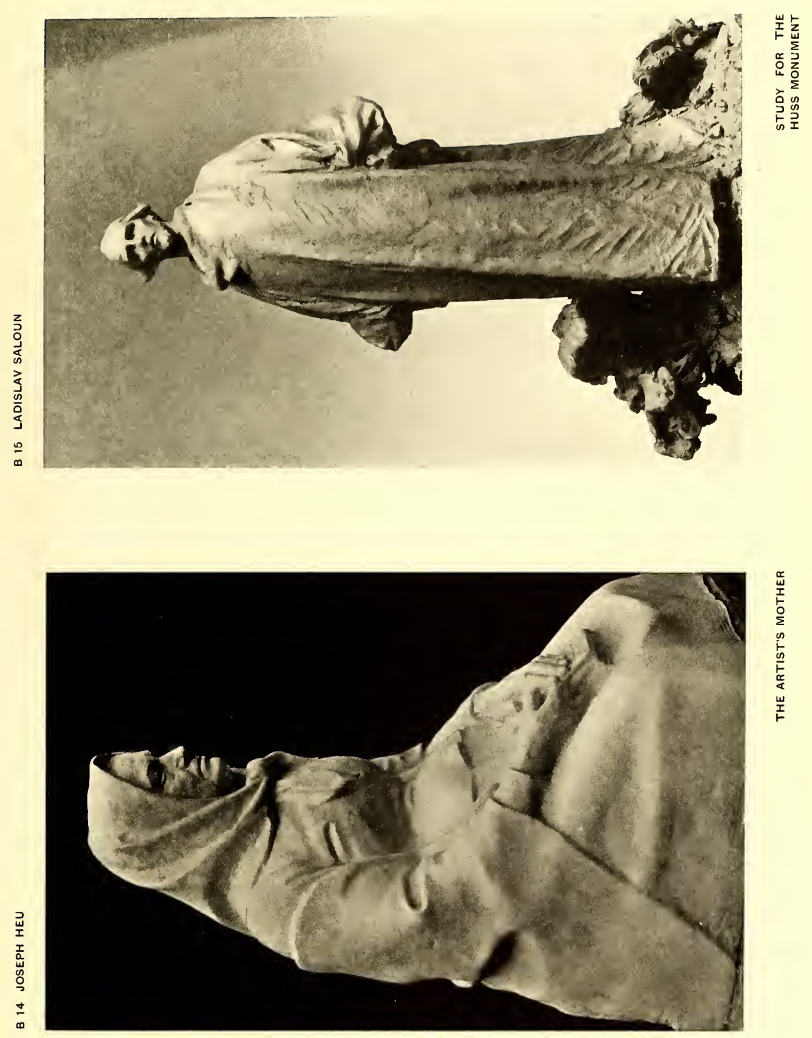

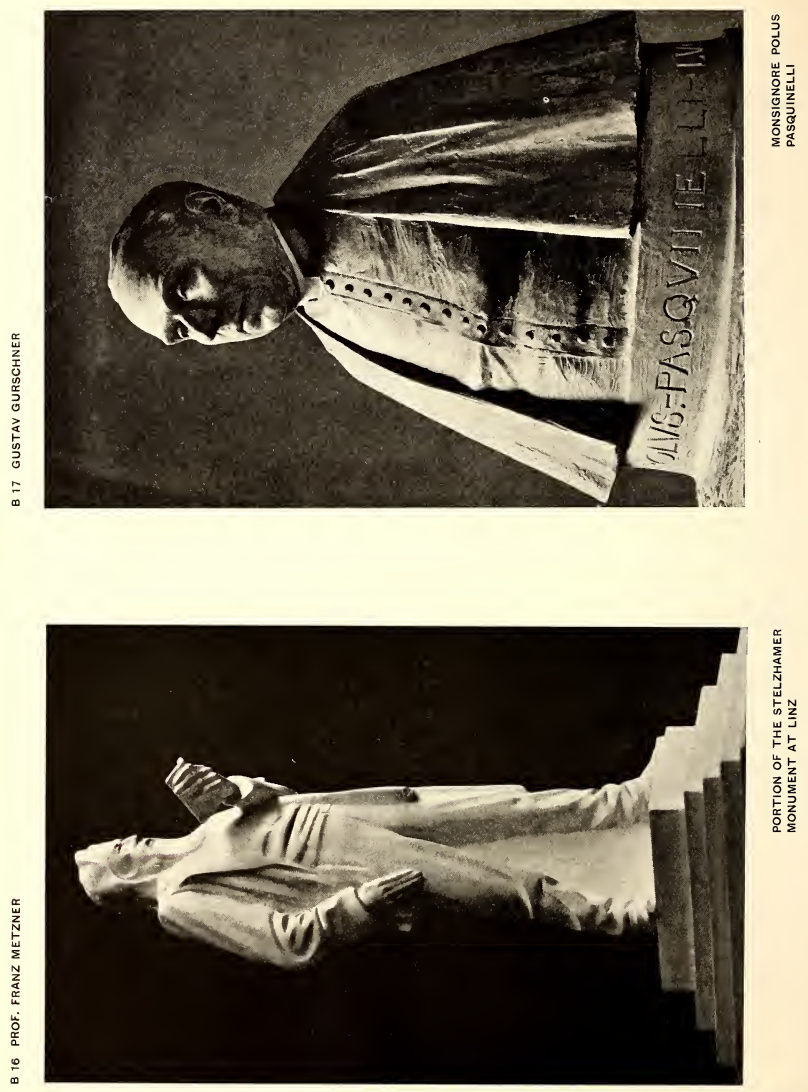


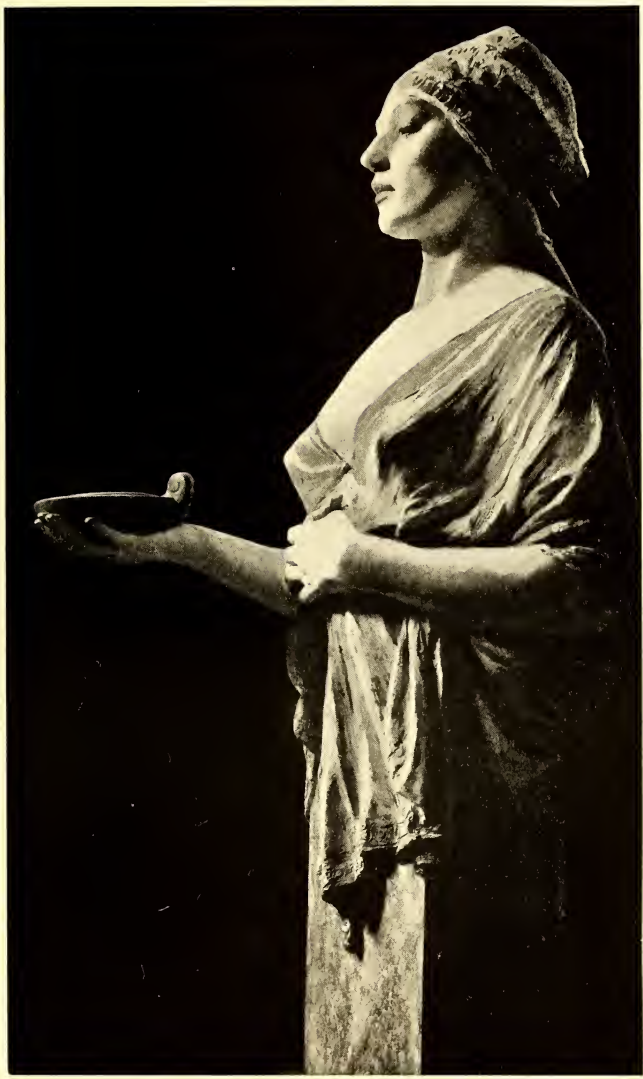



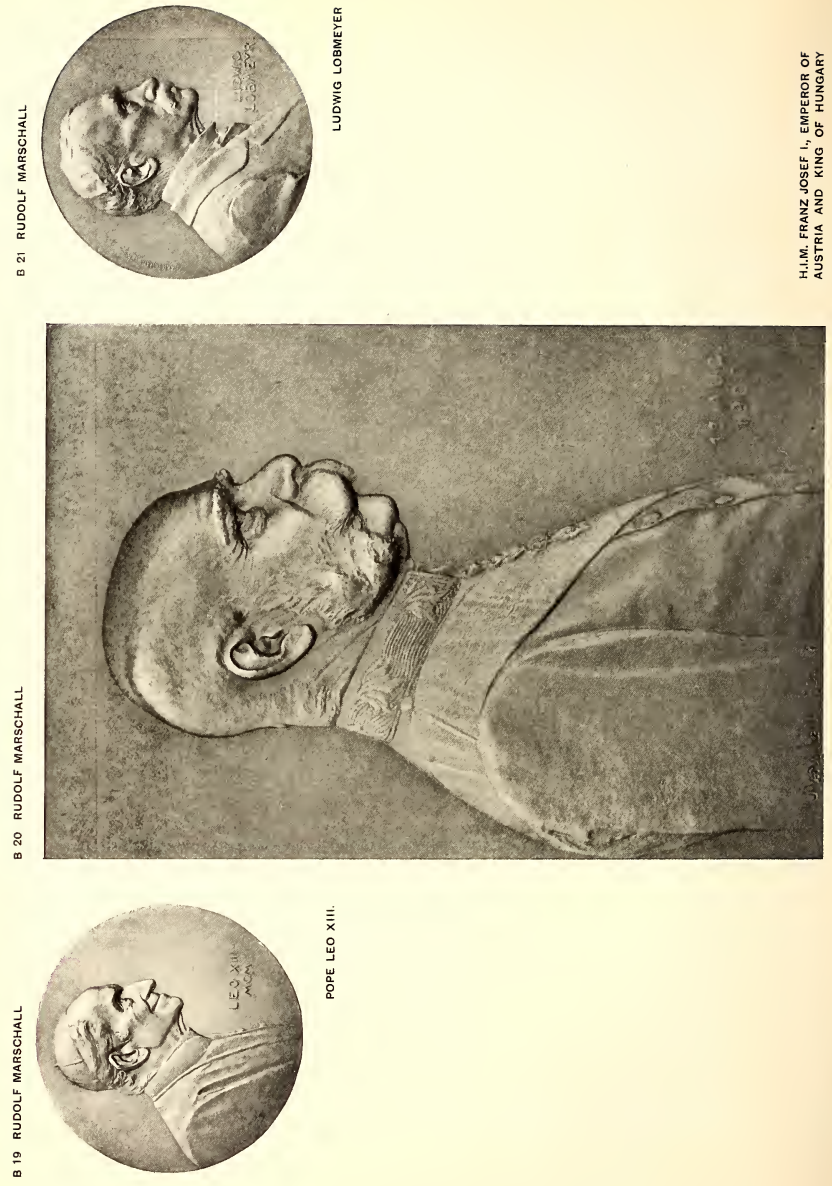


\section{THE ARCHITECTURAL \\ REVIVAL IN AUSTRIA \\ BY HUGO HABERFELD}

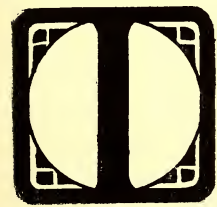

$\mathrm{N}$ the fact that it has taken its rise from the domain of architecture lies the strongest proof of the organic character of the modern art movement in Austria. For whenever a new style makes its appearance, it is in architecture that its first indications are to be seen. During the unrest of transition architecture affirms most emphatically that she is the Urmutter, the proto-parent of all the creative arts which have originated from her as their common source. Architecture is the first among them to accommodate herself to the new spirit, and her conquests and reverses determine the fate of painting and sculpture. For this reason modern Austrian art also began with architecture.

In October, 1895, ere yet there was the slightest thought about "Secession" among us, when our modern painters and sculptors were either to be found among that reactionary group, the old " Künstlergenossenschaft," or pursued their studies abroad, a book made its appearance bearing the title of "Modern Architecture." Its author, Oberbaurat Otto Wagner, who had only the year before been appointed professor at the Vienna Academy, herein formulated, for the benefit of his pupils, his views on the nature and aims of architecture. The book has since run through many editions, but, when it first appeared, it was greeted by Wagner's colleagues with open hostility or even scorn. The rising generation of architects, however, rallied to his cry, and welcomed the bold innovator.

Born in Vienna on the $13^{\text {th }}$ July, $184^{1}$, Wagner attended first the gymnasium at Kremsmünster; then the Vienna Polytechnic, whence he migrated to Berlin, to study at the Bau-Akademie. Ultimately he returned to Vienna and became a pupil of August Siccardsburg at the Academy-an architect whose merits, like those of his friend Van der Nüll, are nowadays much underestimated. He had a marked influence on young Wagner, who found in him a kinship of ideas and sentiments not only in relation to art but in regard to matters in general. Siccardsburg stood foremost among the older generation of Viennese architects in recognising and advocating the 
importance of constructive principles; and being, moreover, a man of the world, with a wide knowledge of its ways, this side of his character sympathetically reacted on Wagner's persevering and practical nature. Then, just at the time when Wagner began to work on his own account, Vienna entered upon that brilliant epoch in which are associated with the first expansion of the city the names of Ferstel, Hansen, Schmidt and Hasenauer, who created that great thoroughfare, the Ringstrasse, famous for its monumental structures. It occupies the site of the glacis which had encircled the old city with a girdle of green. That was in the third quarter of the past century, a period when in German art and science the historic view prevailed-that view against whose pernicious domination young Friedrich Nietzsche launched the second of his "Unzeitgemässe Betrachtungen."

The architects just mentioned were artists of large ideas, but themselves imposed limitations on their capabilities, in the belief that only in one or other of the historic styles could they give expression to their architectural aims. They enjoyed a great reputation in Vienna, and settled for years to come the direction of architectural activity there. But while their surpassing talent enabled them to thoroughly master the ancient styles without sacrificing their independence, their pupils and imitators, on the other hand, became hopelessly enslaved to these styles. With them all that an architect need do was to copy, with more or less skill but without a particle of "geist," the examples given in the text-books. One needed to see with one's own eyes the low ebb to which architectural understanding and taste had fallen to realise the pressing need of a change like that which Wagner inaugurated.

Wagner's great merit-one may say the greatest-is to have instilled into architecture a new life; it is through him that it has ceased to have that petrified rigidity, that weary pedantic character it once had. "Art exists for mankind, not mankind for art," he once wrote; and thus he regards architecture as a living force fulfilling individual needs and aspirations, and at the same time a monumental document of social life. But while thus regarding architecture as the highest expression of human knowledge ever striving to attain the divine-the highest because nature provides her with no model for guidance-he requires of her that, like an attentive handmaiden, she shall be subservient to all the requirements of modern life, and it is the highest gift an architect can possess to perceive these needs as they arise. Once the end to be aimed at is clearly recognised, the question of appropriate materials calls for solution. From these two c ii 
factors-purpose and material-there ensues what we call form or style. Hence there is no such thing as a style which is universally appropriate and applicable. Style being a product of these two evervarying factors, its determination must depend on concomitant circumstances such as locality, climate and so forth; while all new methods and inventions which may serve to enhance comfort have to be taken into account.

Previous to his appointment as professor at the Academy, Wagner had erected a large number of buildings-some public, like the Länderbank and Dianabad, but principally private houses and flats; and he even built on a large scale at his own risk. In 1894, the year of his appointment, he commenced his first great municipal undertaking - the construction of the Metropolitan railway in Vienna. When he came on the scene another architect was already in the field with plans for this railway, and the eventual adoption of Wagner's scheme seemed to denote the victory of the new spirit over the old. Wagner steadily followed his new principles, first of all in his plans, and afterwards in construction-tentatively at first, but with more and more freedom during the progress of the undertaking-always keeping in view the end to be subserved-namely, rapid, safe, and comfortable travelling, and adapting the form and decoration of the various structures in harmony with their purpose and the material employed. In the Gumpendorfer Bridge, a huge structure which carries the railway high above the streets, the decoration is meagre, consisting only of vertical rows of wreaths, discs, and festoons, Wagner's favourite motifs. The pavilion at Hietzing, used as a private station by the Imperial Court, although quite a plain building, is as pleasant and graceful in appearance as any little rococo temple. Besides the two factors-purpose and material-there is another which is taken account of by Wagner as affecting form and decoration, that of environment. Thus the proximity of Karlskirche determined the diminutive size and ornate character of the station buildings on Karlsplatz, and the covered-in precincts of the station on Franz-Josef-Quai, the gallery-like construction looking towards the Danube Canal. On this one achievement, then, there was brought to bear a wealth of experience and inventiveness, and even engineering knowledge, such as is rarely to be met with among architects.

Since then not a year has passed without some extensive undertaking being planned and thought out down to the smallest detail by Wagner, regardless of whether it would be executed or not. The year 1898 brought his truly original plans for an Academy of Fine 
Arts, for Theophil Hansen's luxurious structure on the Schillerplatz no longer sufficed to meet modern requirements and views. While this covers a superficial area of 5,429 square metres, Wagner requires for his plan 122,500 square metres, and on that account has placed it in the outskirts of the city. A wonderfully co-ordinated architectural group forms the foreground of his clever project. The central building, surmounted by a lofty dome, and destined to serve as a great hall or Ehrenhalle for ceremonial occasions, is to be of granite, with metal decoration partly of beaten copper and partly of gilded bronze, the latter more particularly for the circle of wreathbearing figures-symbolizing Victory-above the dome. From this central building leafy walks lead off right and left to the side buildings, longitudinal structures in which the galleries are to be located. The problem of lighting is solved in the most natural and practical way, the side aisles obtaining their light laterally, the centre aisle from above. In the rear are situated the pavilions to be devoted to instruction and work, planned with most lavish regard for the requirements of modern art teaching. A model of the entire scheme was shown at the second exhibition of the "Secession," but the project has not been carried out; nor have Wagner's plans for the reconstruction of the Capucine Church, containing the crypt of the Imperial House of Habsburg, nor his first plans for a modern church, though with regard to this latter he has utilised the experience and results derived from it in a church he is actually carrying out. But the most interesting among those of his projects which have not been carried into execution is that for the Vienna City Museum, which has culminated in a conflict of opinion more passionate than any which has raged about a building in Vienna for many long years. The matter is at present in abeyance, but a genuine appreciation of the pre-eminent qualities of Wagner's scheme appears to be spreading, and we may yet hope to see the museum standing alongside the Karls church in surroundings worthy of it, for the modern structure of glass and iron aptly expresses its practical purpose, just as Fischer von Erlach's baroque fabric suggests the ritual religiousness of his time. Of undertakings which have not simply remained on paper two or three of recent date call for particular mention. In the first place there are the Miethäuser, or flats, in the Friedrichstrasse, which Wagner erected in the summer of 1899 , and of which the two fronting on the street may be regarded as models of the modern type of Viennese houses of that class, just as, at an earlier date, Hansen's Heinrichshof represented the older type of houses in the Ringstrasse. c iv 
Another building now approaching completion is the church for the Lower Austrian Lunatic Asylum in Breitensee, an outlying suburb of Vienna. The church forms a quadrangle surmounted by a dome which, with its overlay of red copper plates, is visible from a great distance. The façade consists of a columnar portico with roof, and is surmounted by two towers bearing statues of the patron saints of the country. The lunette above the portico contains a pictorial mosaic by Professor Koloman Moser, to whom is also due an altar-piece representing "Paradise." The interior is a model of precisely calculated adaptation to requirements. As an instance of Wagner's thoughtfulness in regard to details, it may be mentioned that when designing the confessional boxes, (which are usually turned out in factories after a stereotyped pattern), he took into account a possible hardness of hearing on the part of the priest. Then finally we have the Post Office Savings Bank building, another masterly creation. As regards its style, Wagner's object was to give the structure a modern character appropriate to its purpose as public offices. It is a brick building, the lower portion of the exterior being faced with granite, and the above with slabs of Laas marble and stoneware, while the roof is of slate. Inside, the predominant feature is the quadrangular central hall, with a superficial area of more than five hundred square metres and divided into three aisles by two rows of pillars. In a short time the building will be finished, but with untiring energy Wagner is already hard at work on new projects, one of them a great bridge over the Danube Canal, while another is among the greatest he has yet essayed-the plans for the Palace of Peace at the Hague, which he has been invited to submit in competition.

Before going on to speak of Wagner's pupils and continuators, we must mention three among the most notable of a large number of architects who stand apart from him, or in opposition to him. First there is Oberbaurat Friedrich Ohmann, the chief among them. $\mathrm{He}$ is, like Wagner, a professor at the Vienna Academy, and is an adherent of the school founded by Friedrich Schmidt and continued by Von Luntz. In 1899 he was entrusted with the supervision of the construction of the new Imperial Hofburg, already commenced by Hasenauer. Ohmann was born in 1858 , and after studying at the Vienna Polytechnic under Karl König, an able but now decidedly underestimated man, became a pupil of Friedrich Schmidt at the Academy. Though receiving his most decisive impressions from the historic school, his position towards it has never been that of a mere imitator, but always that of one who derives æsthetic 
enjoyment, whose artistic individuality and creative power are not strong enough to conceal in his work the influence of the beauty of the past. The baroque style more especially has found in Ohmann a superlative draughtsman; it was in Prague that he made close acquaintance with it, while professor at the School of Applied Art. At that time, too, he erected a number of houses in Prague, restored churches and castles in various parts of Bohemia, and worked out the plans for the museums in Reichenberg and Magdeburg-all of them excellent achievements, though here and there wearing a hybrid aspect through the conjunction of both historic and modern styles. At Vienna, whither he was called from Prague, he has approximated more closely to modern views, as is shown by works carried out by him there, both public and private. But his talent has not yet reached its fullest development, and one may expect from him yet finer achievements than hitherto.

Another man who at first favoured the historic school is Max Fabiani, a professor at the Vienna Polytechnic; but he has, obviously under the influence of modern ideals, attained by degrees to a freer conception, which has so far been most sympathetically manifested in two business houses. The last of this trio of architects is Franz, Freiherr von Krauss, who has diligently experimented in many directions, always with aptitude but without any pronounced originality. His greatest successes so far have been the two theatres in Vienna-the Jubiläumstheater and the Bürgertheater.

Otto Wagner has trained quite a number of architects, some of whom have already become celebrated. At their head is Professor J. M. Olbrich, who left Hasenauer and went to Wagner. Olbrich is a man highly gifted, impulsive and imaginative, a poetic interpreter of space, and a decorator of rare taste. Through Wagner he acquired self-restraint and a severely critical attitude towards himself and art. Still Olbrich retained so great a fund of enthusiasm that he became the leader of the younger generation of architects. His Vienna buildings, true documents of the "Ver Sacrum," have all of them provoked the fiercest conflict of opinion. His first effort was the "Secession" building, erected during the space of a few months, a work vigorous and fresh in conception, sober yet impressive, well-proportioned and graceful, and withal a personal creation yet dictated by "purpose." The particular problems presented by an exhibition building have never been better solved; the interior has been so planned that instead of being fixed the walls are movable, so that any desired portion of the space may be available with top light or side light. Olbrich, c vi 
too, was the first to plan country houses of a modern type in the outskirts of Vienna-and he designed the first monument of a modern character in a Vienna cemetery. He would doubtless have been a pioneer amongst us in many other directions had not the Grand Duke of Hesse summoned him to Darmstadt in 1899 . We can see from his book "Ideas" how much Austrian art has lost by Olbrich's migration to Germany.

The next and, after Olbrich, perhaps the most important of Wagner's pupils is Professor Josef Hoffmann. He was born in 1870 , at a little Moravian town, and in 1897 joined the Vienna "Secession," for whom, in the following years, he designed and arranged some very fine exhibition interiors. In 1899 he became professor at the School of Applied Art, and in I 903 founded, in conjunction with Professor Koloman Moser and aided by a wealthy and generous patron of art, the organisation known as the "Wiener Werkstaette," to which he devoted his whole attention on his retirement from the "Secession." Hoffmann began as they all began-he allowed his imagination full play. In this way there came into existence on paper the most colossal edifices, among them the vast scheme for a Palace of Peace, a gigantic combination of temples, piers, gardens, fountains, etc. Then, when Hoffmann received his first real commission, it became clear that along with his imaginativeness he possessed, in perhaps a still greater measure, the constructive sense. In I 900 he began the construction of his villa colony on the "Hohe Warte," a plateau charmingly located in the midst of a hilly country, typically Viennese in character, and the group of dwellings he has erected there blend happily, both in the aggregate and individually, with their surroundings. The houses are situated in the midst of gardens which have been planned as architectural adjuncts, not in gardener fashion, and are all alike in so far that they all bear the conspicuous impress of their designer, though each is different from the rest. The windows are not placed according to any apparent symmetrical system, but seem to have been put here and there just at those places where the architect thought they were required. The interiors are of a simple, homely character, pleasantly and conveniently arranged. In Austria Hoffmann has, up to the present, been most successful in planning private residential houses as far as possible in harmony with the character of the inmates, and in which full regard is paid to comfort. At the same time he has successfully undertaken houses destined to accommodate a larger concourse of people; for example, a workmen's hotel at Kladno, dating from I902, and the Sanatorium in Purkersdorf, 
near Vienna, finished last year, in which all the complex needs of a hydro have been provided for in the most simple, ingenious and agreeable manner.

Quite lately Josef Plecnik, by birth a Slovene, has come so much to the front that we feel justified in giving him the third place. Art-lovers early recognised and appreciated his talent, perceiving throughout his work a remarkable sincerity of feeling savouring almost of early Christian times. From his religious fervour, characteristic of the Southern Slavs in general, they anticipated that he would some day attract the notice of the world by some achievement in the domain of modern ecclesiastical architecture, and if he has not already fulfilled these expectations it is not his fault, but simply because no commission has been forthcoming.

Among Wagner's pupils of this generation there remains to be mentioned Leopold Bauer. Quite early in his career as an architect, and when he had hardly left the Academy, he published a book, "Verschiedene Skizzen, Entwürfe, und Studien" ("Sundry Sketches, Designs and Studies"), which showed him to be the most radical and consistent among his brother architects. Six years have passed since then, and Bauer's views have undergone a marked change. Not that he has in any point diverged from modern principles, but his attitude towards the architecture of the past is no longer one of downright opposition. He has come to recognise that if architecture as an art is to be a vital force, it cannot wholly neglect tradition. He would step in where the organic evolution of Viennese architecture was suddenly interrupted at the beginning of the nineteenth century, the period of the Biedermaier style. Then we must just refer to Jan Kotéra, who was one of the founders of the "Manes" Artists' League, and is a leading organiser in the art-world of the Czechs. His erections are principally country houses, and he successfully and happily combines in them constructive principles with the traditional Slavic mode of building. Finally the brothers Hubert and Franz Gessner deserve honourable mention for their Artisans' Home in Vienna and the District Offices of the Krankenkasse (Sick Club) at Floridsdorf-both of them structures admirably fitted for their functions, and permeated by a genuine feeling for social welfare. As to the younger disciples of Wagner their number is legion, and we must refer readers to the annual publications of the "Wagner-Schule." In these confirmation will be found for the assertion that contemporary architecture in Austria can challenge comparison with that of other countries. 

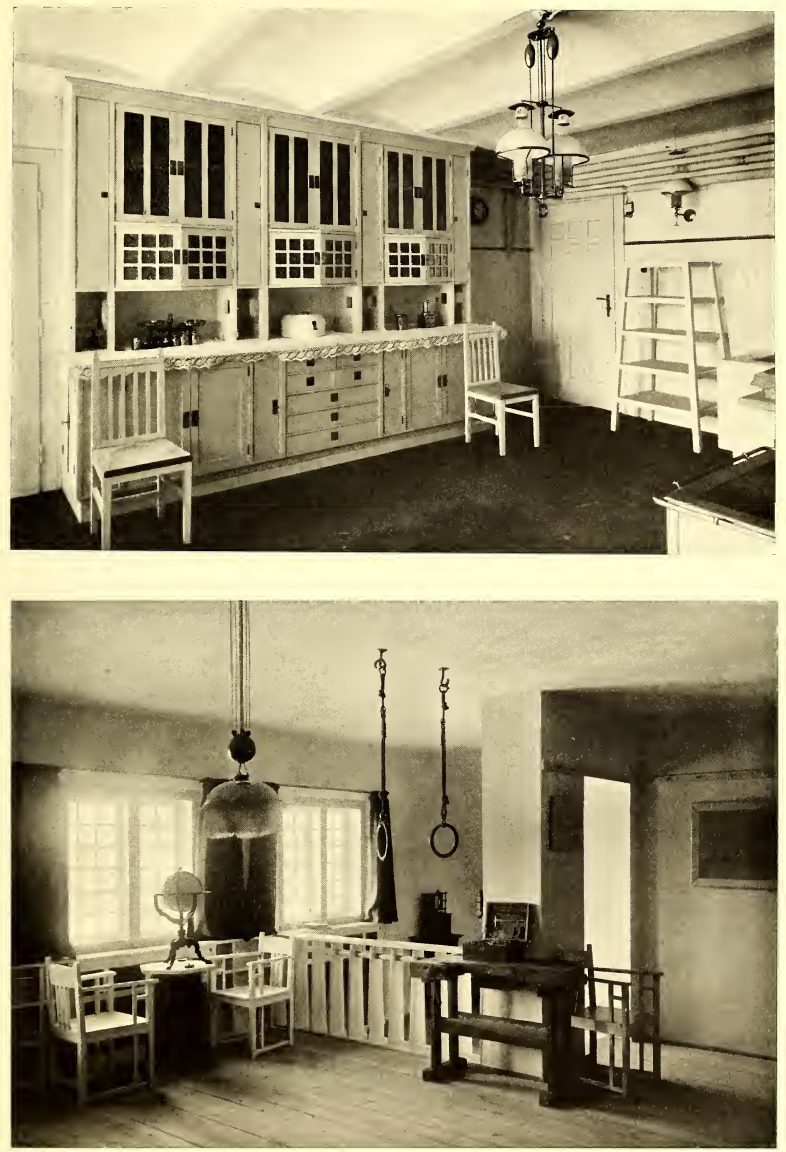
C 3 LEOPOLD BAUER

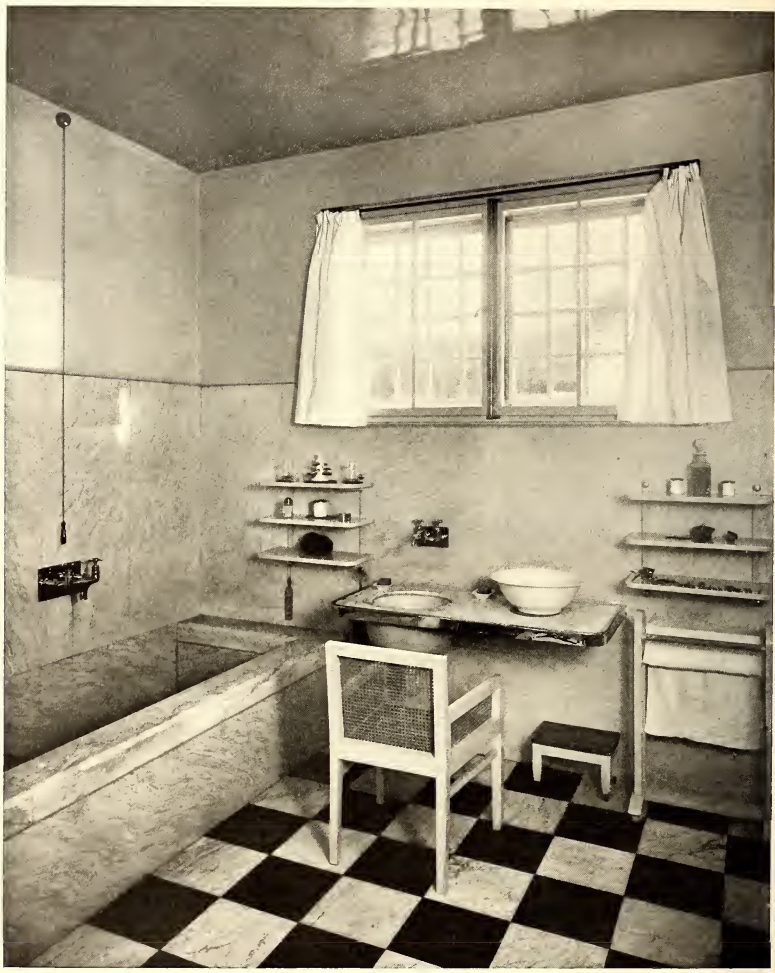




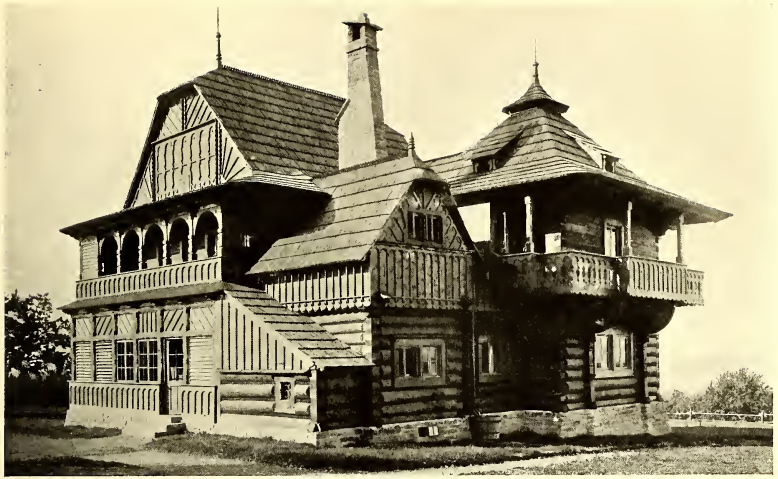

C 5 WUNIBALD DEININGER

COUNTRY HOUSE

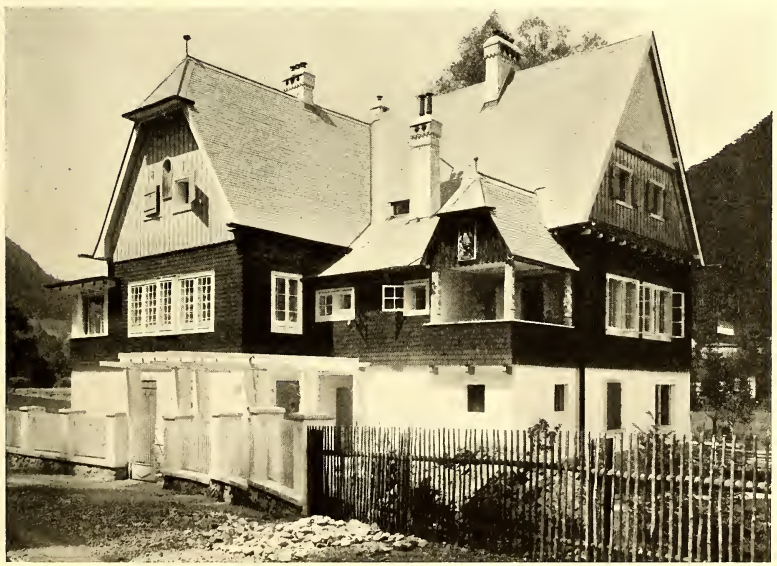




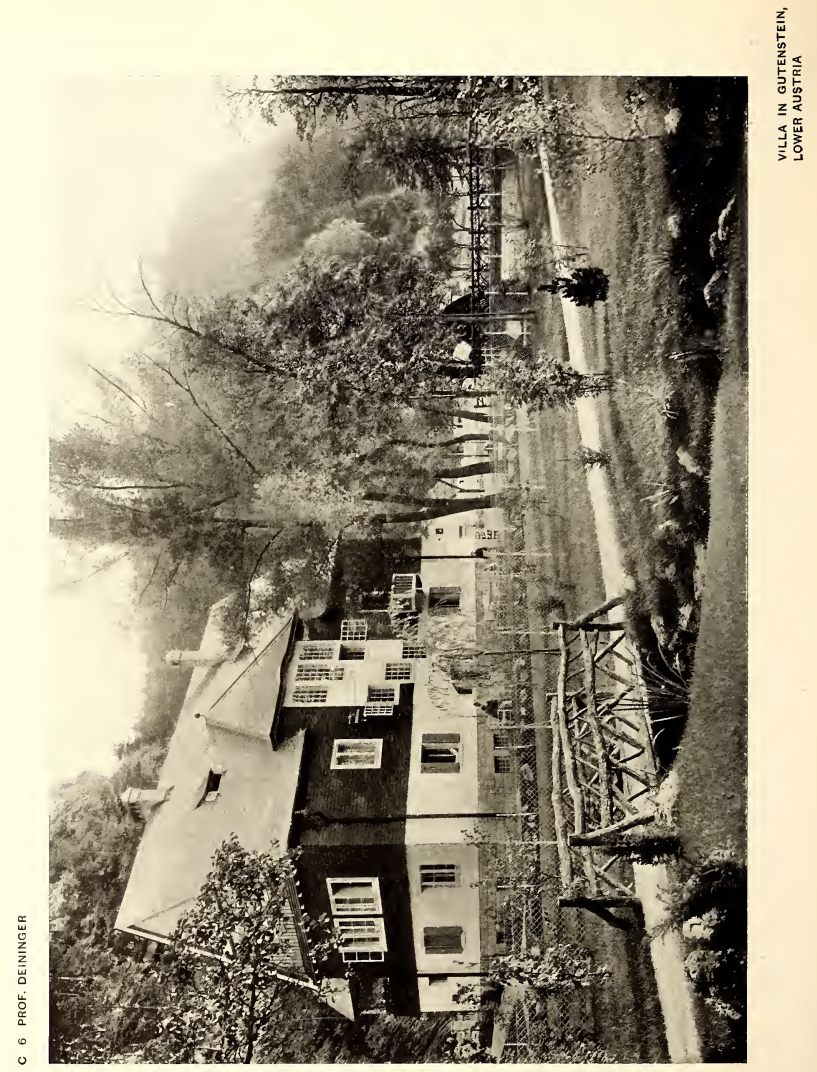




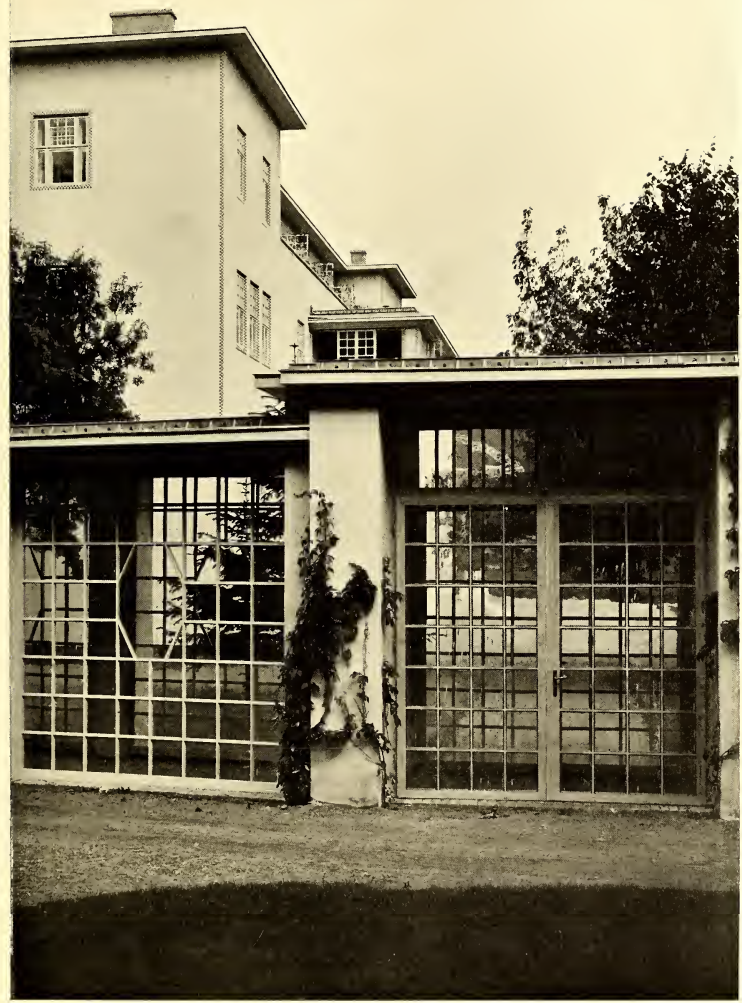

COVERED PAVILION IN THE SANATORIUM AT PURKERS DORF. EXECUTED BY THE WIENER WERKSTAETTE (BY PERMISSION OF HERR HOFRAT KOCH) 


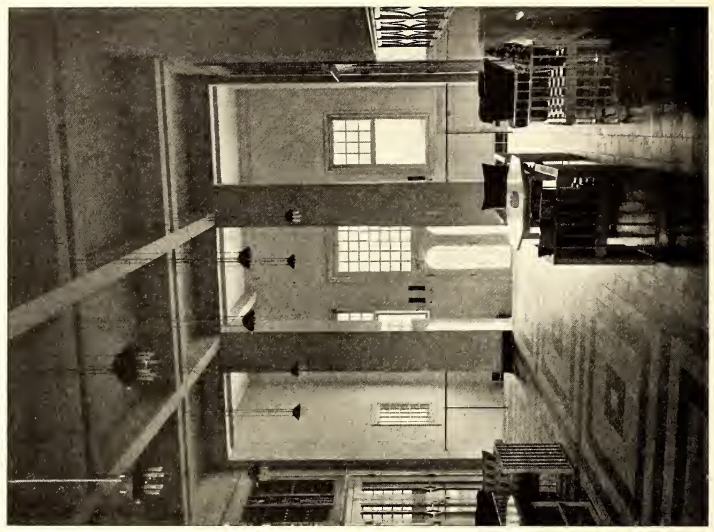

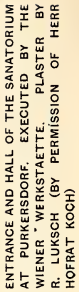

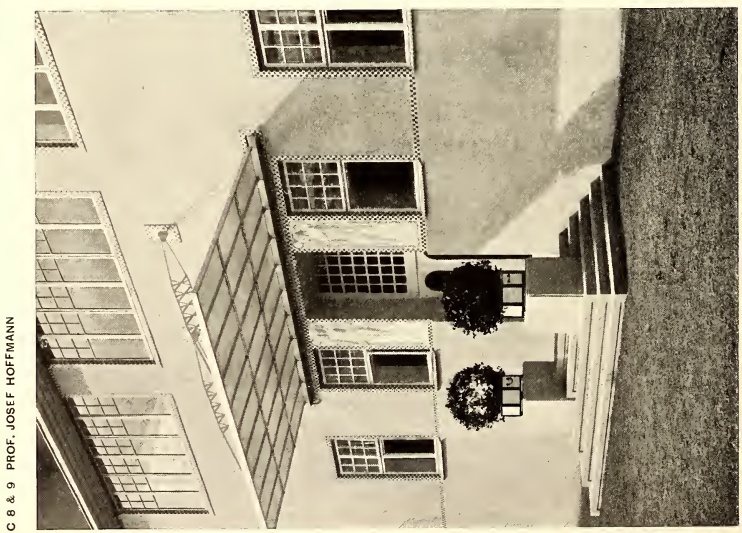




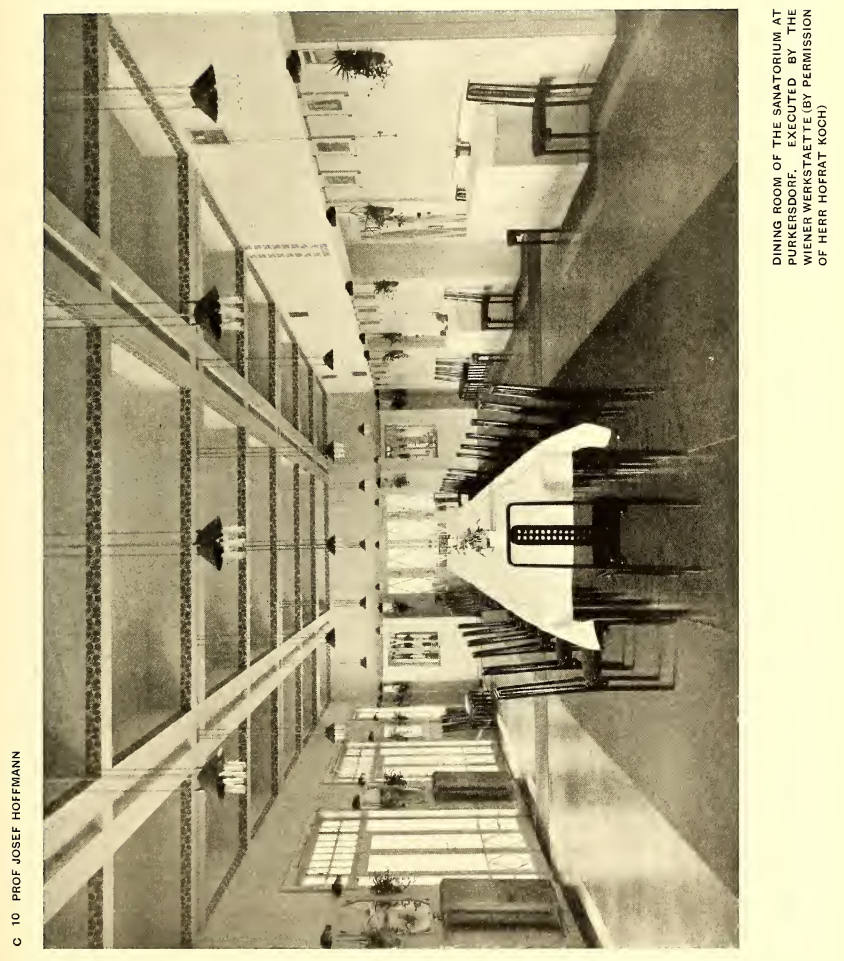


C 11 \& 12 PROF. JOSEF HOFFMANN
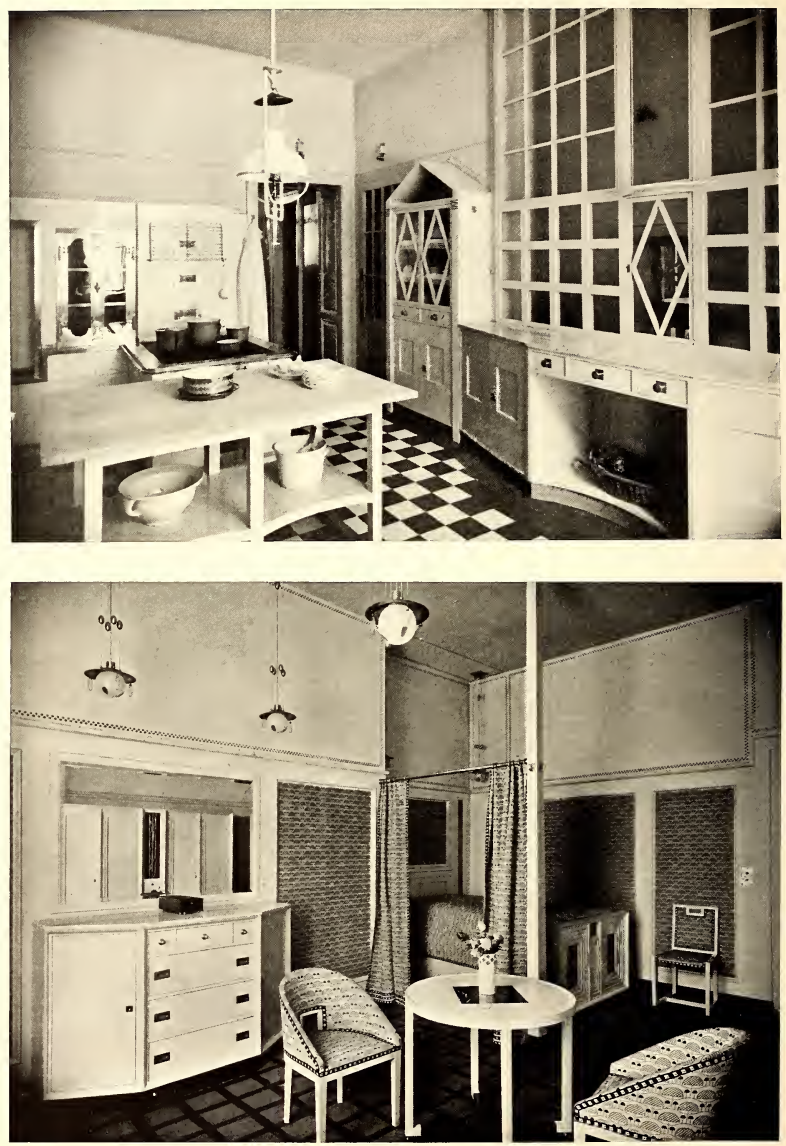

KITCHEN AND BEDROOM EXECUTED BY W. MÜLLER VIENNA. TEXTILES BY BACKHAUSEN \& SONS, VIENNA 


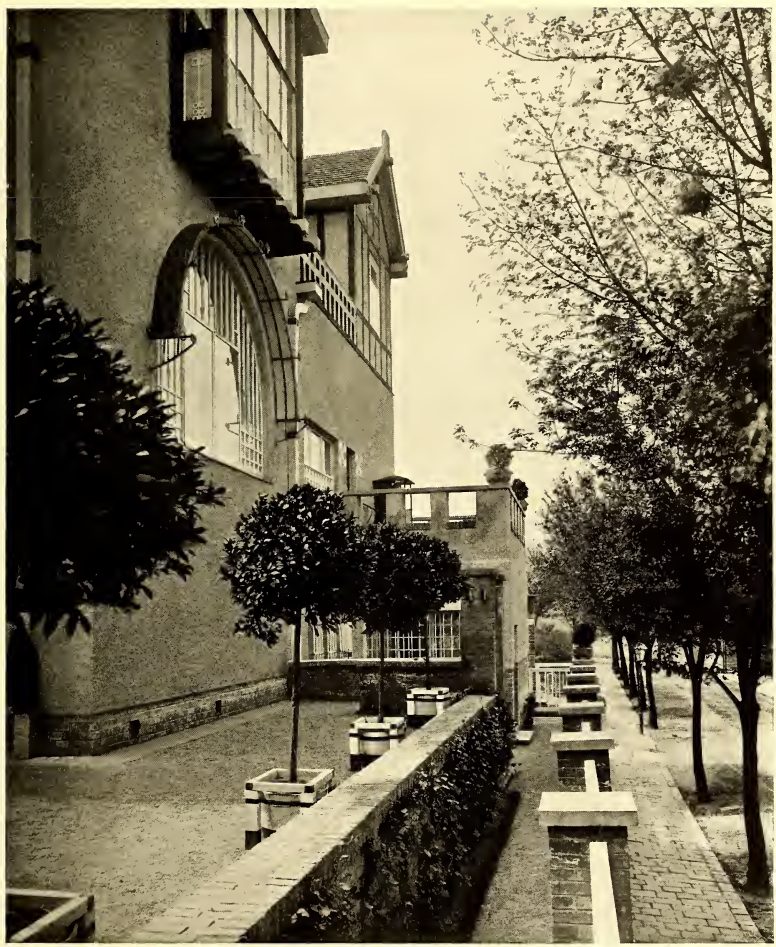




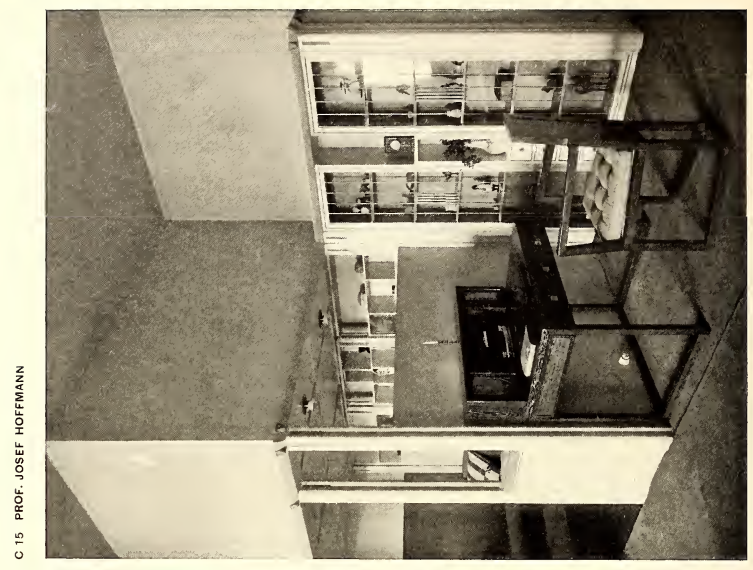

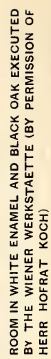

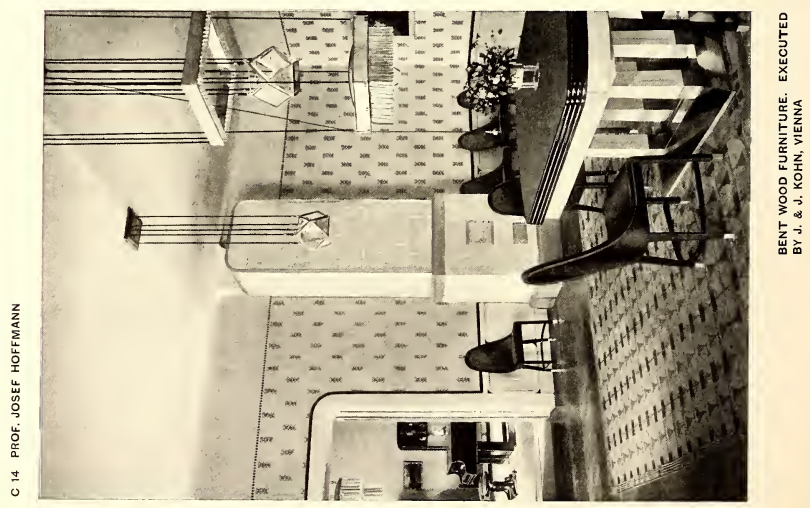




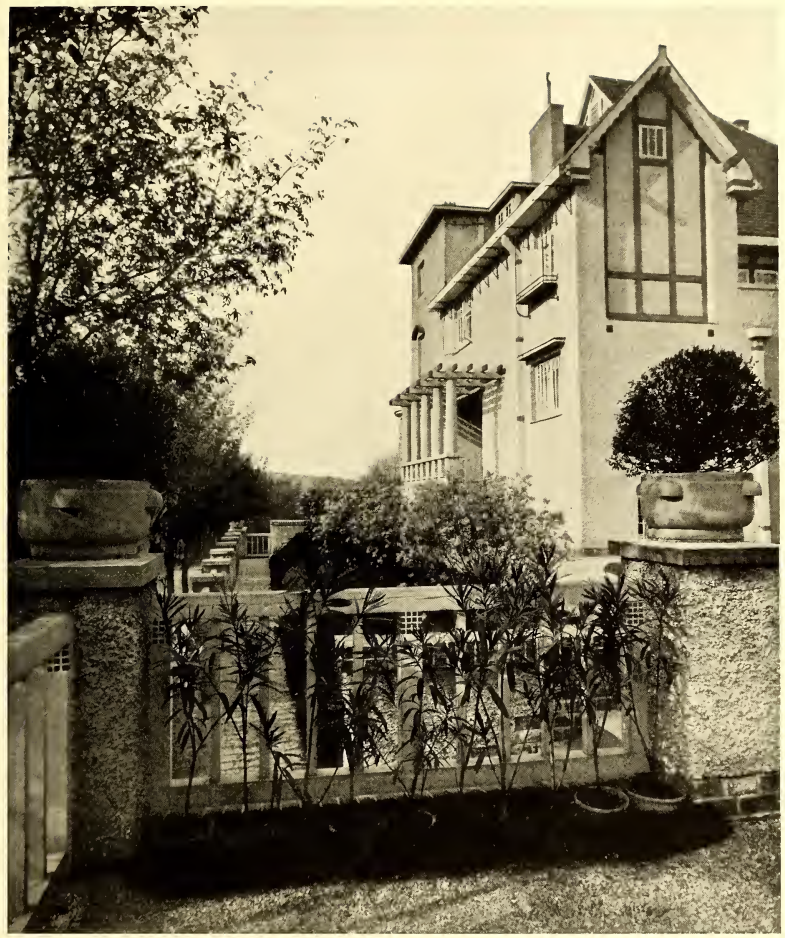




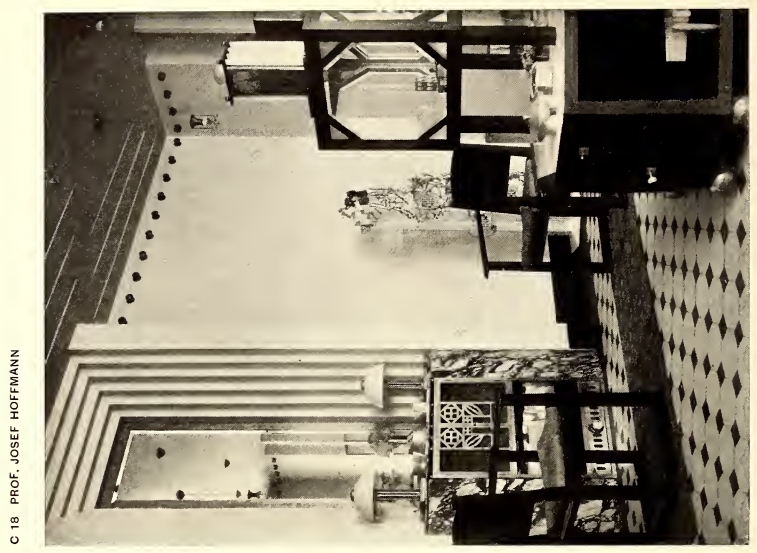

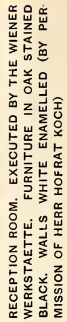

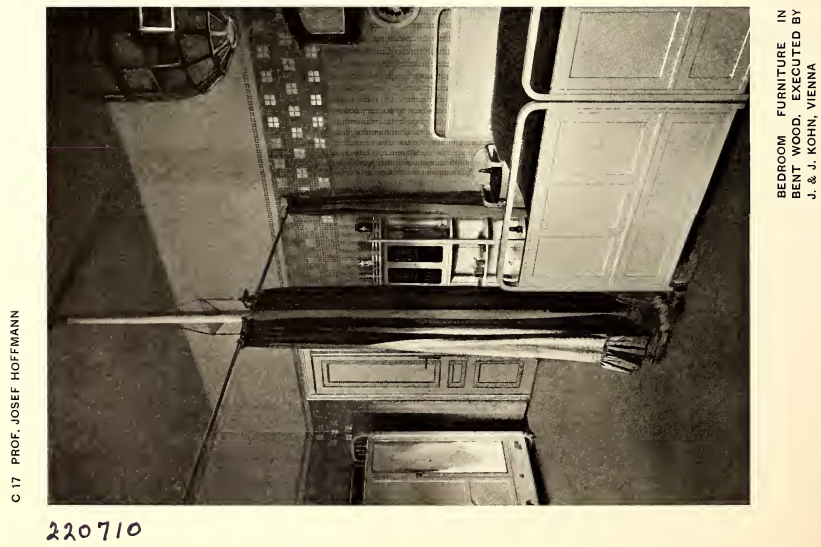




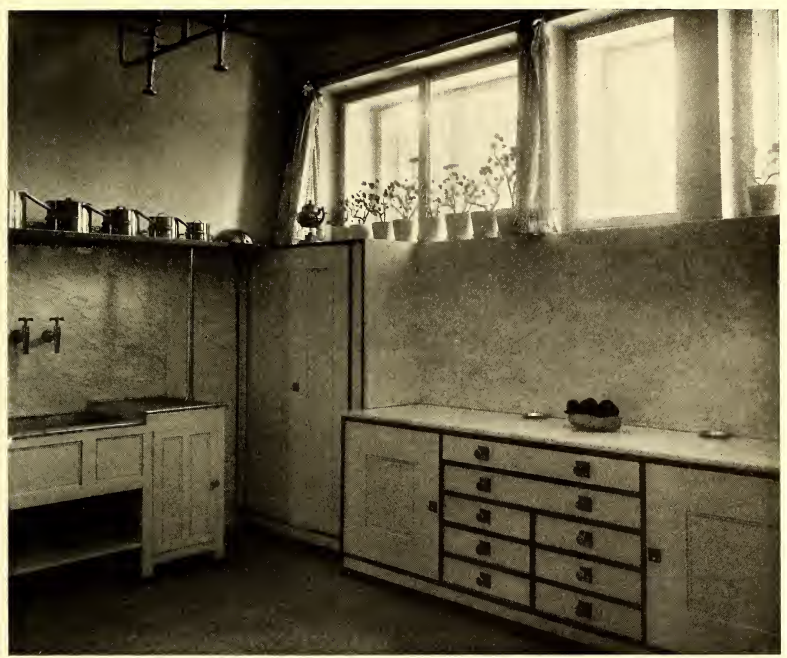



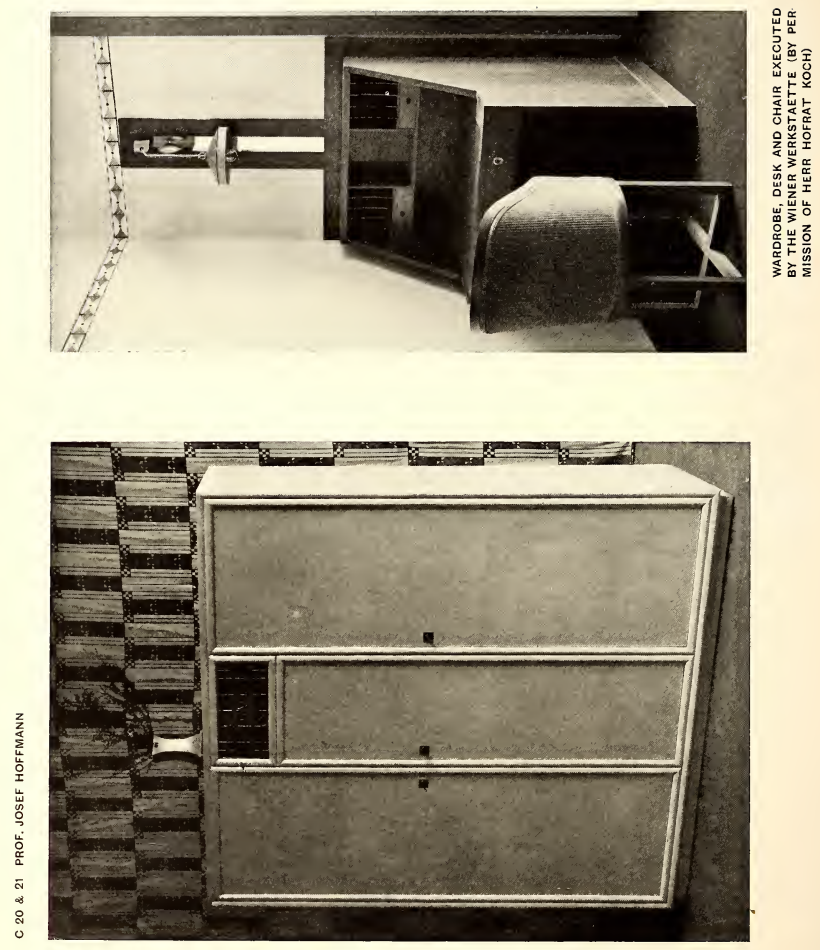
C 22 \& 23 PROF. JOSEF HOFFMANN
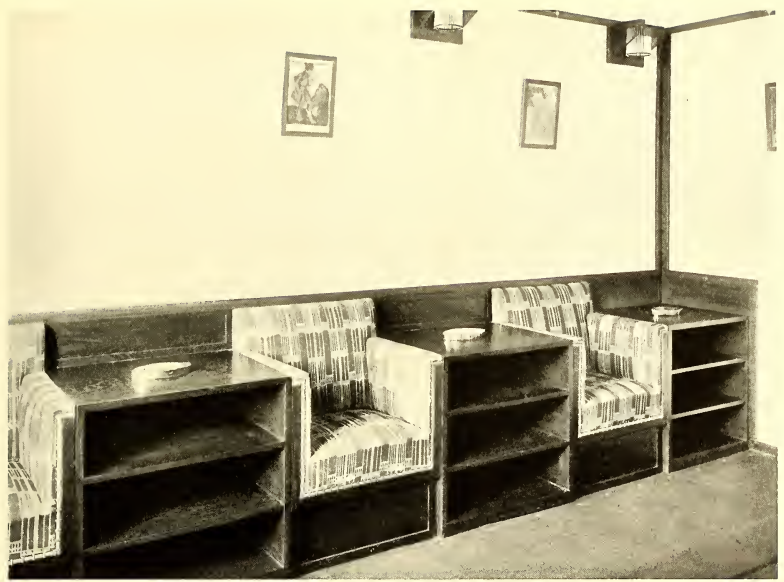

BILLIARD ROOM EXECUTED BY THE WIENER WERKSTAETTE (BY PERMISSION OF HERR HOFRAT KOCH)

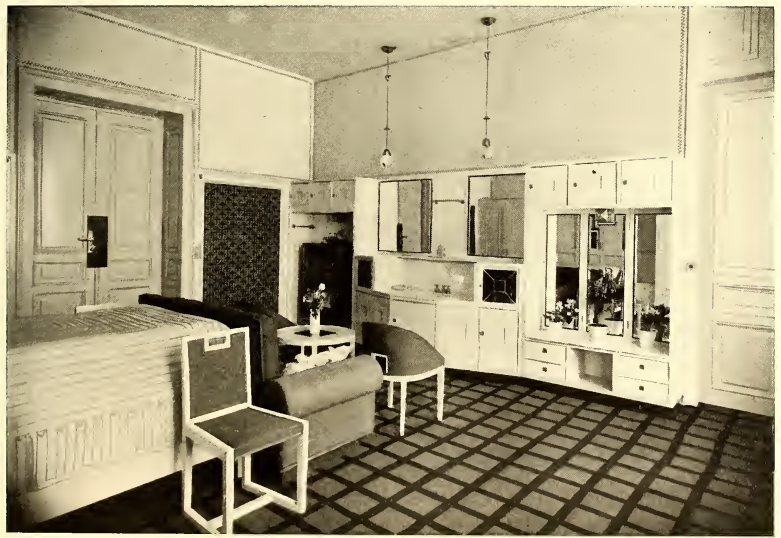

BEDROOM EXECUTED BY W. MULLER, VIENNA 


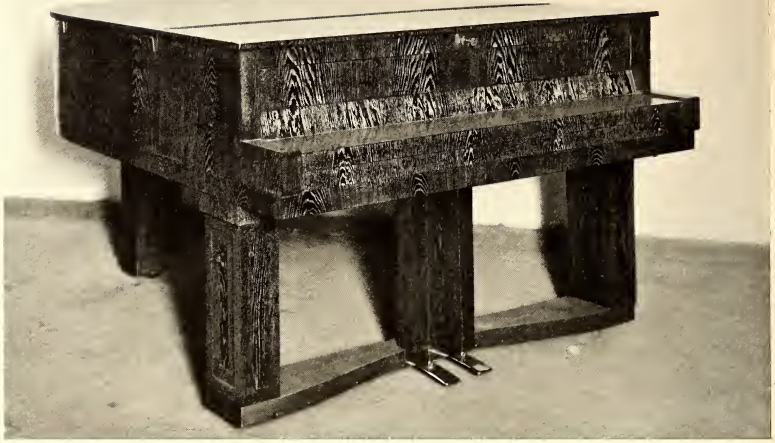

PIANO IN OAK STAINED BLACK EXECUTED BY BÖSENDORFER, VIENNA

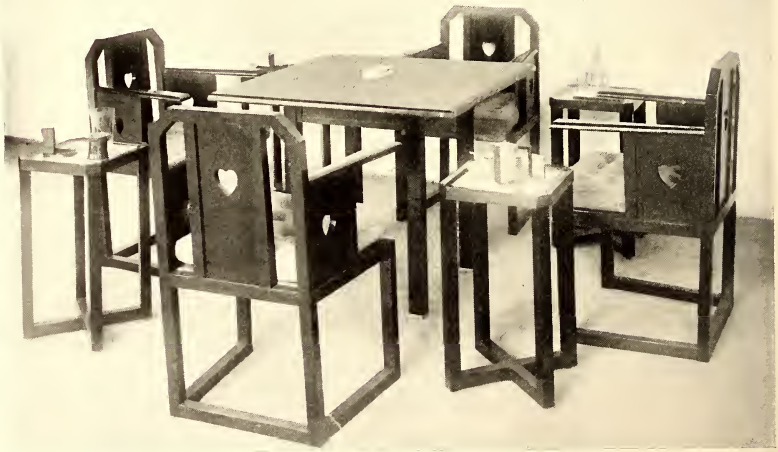

CARD TABLE AND CHAIRS EXECUTED BY THE WIENER WERKSTAETTE (BY PERMISSION OF HERR HOFRAT KOCH) 
C 26 BARON F. KRAUSS.

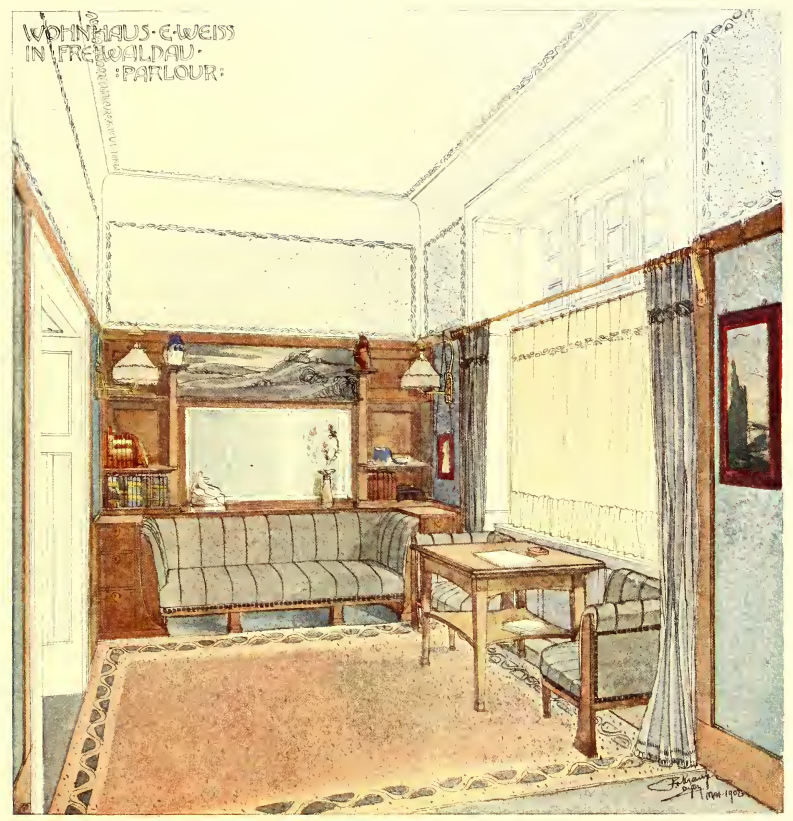


. 


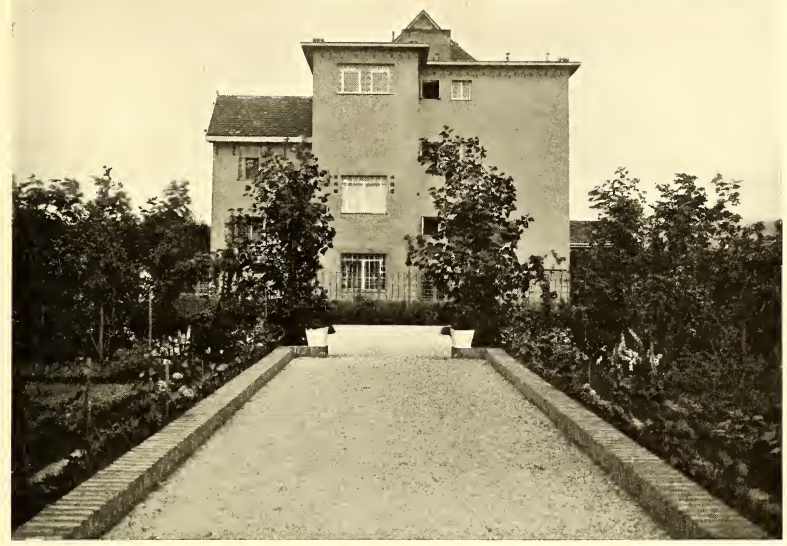

VILLA IN VIENNA

C 28 JAN KOTÉRA

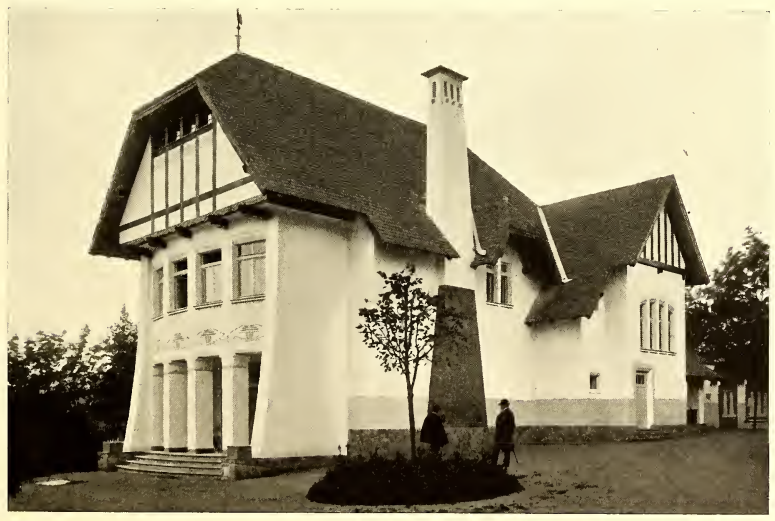

VILLA IN BOHEMIA 
C 29 JAN KOTÉRA

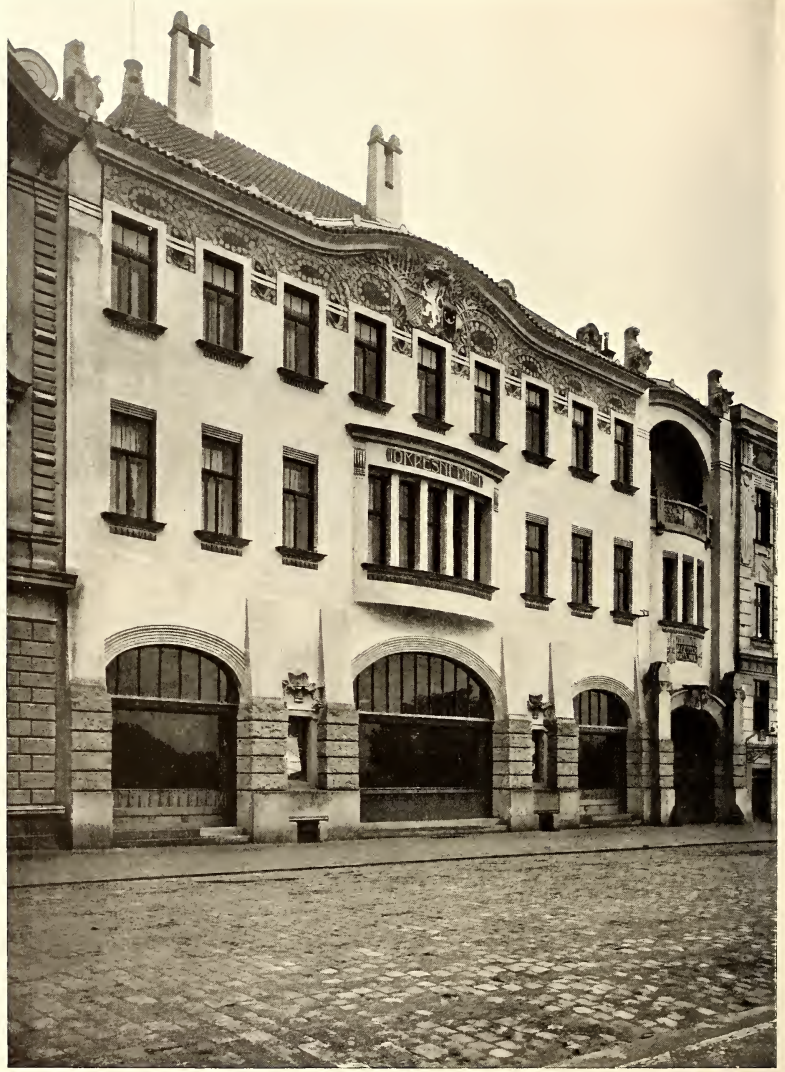

PUBLIC OFFICES AT KRALOVÉ

HRADEC IN BOHEMIA 


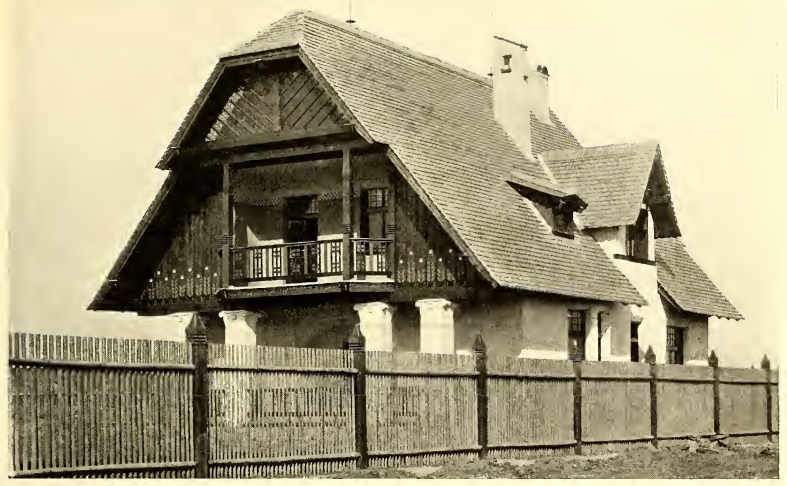

COUNTRY HOUSE

C 31 STANISLAW WITKIEWICZ

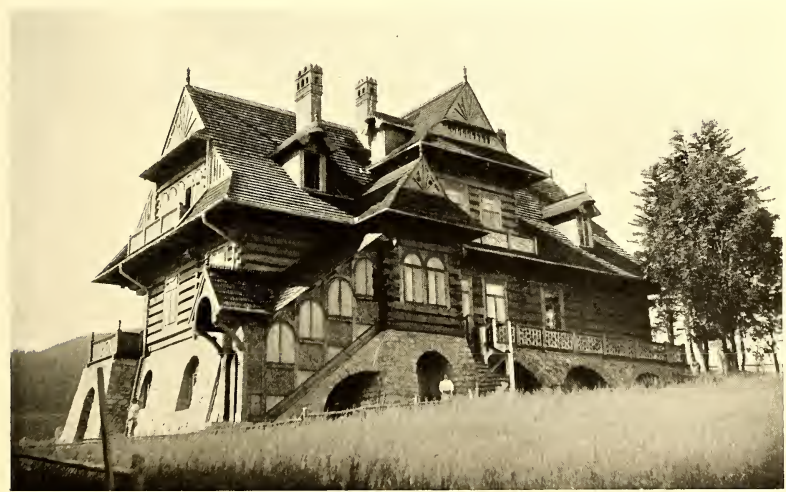

COUNTRY HOUSE IN ZAKO PANE STYLE, GALICIA 


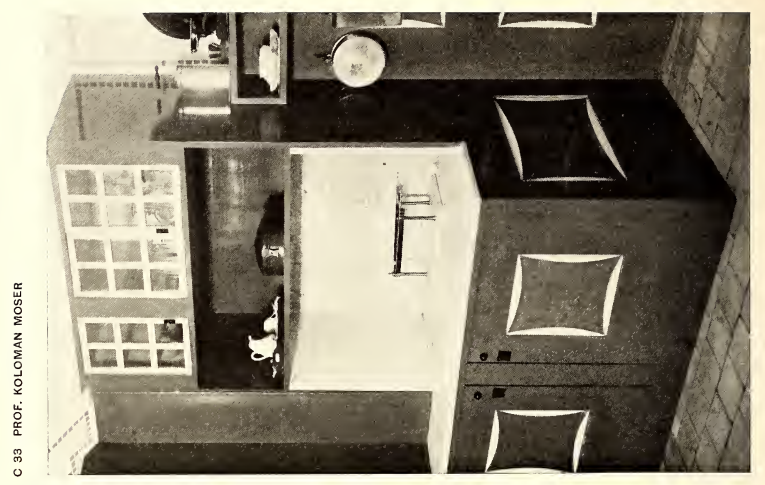

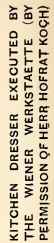

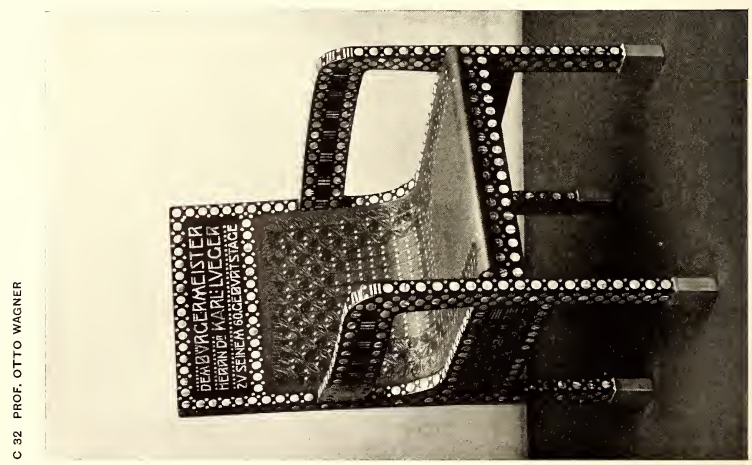

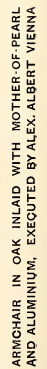




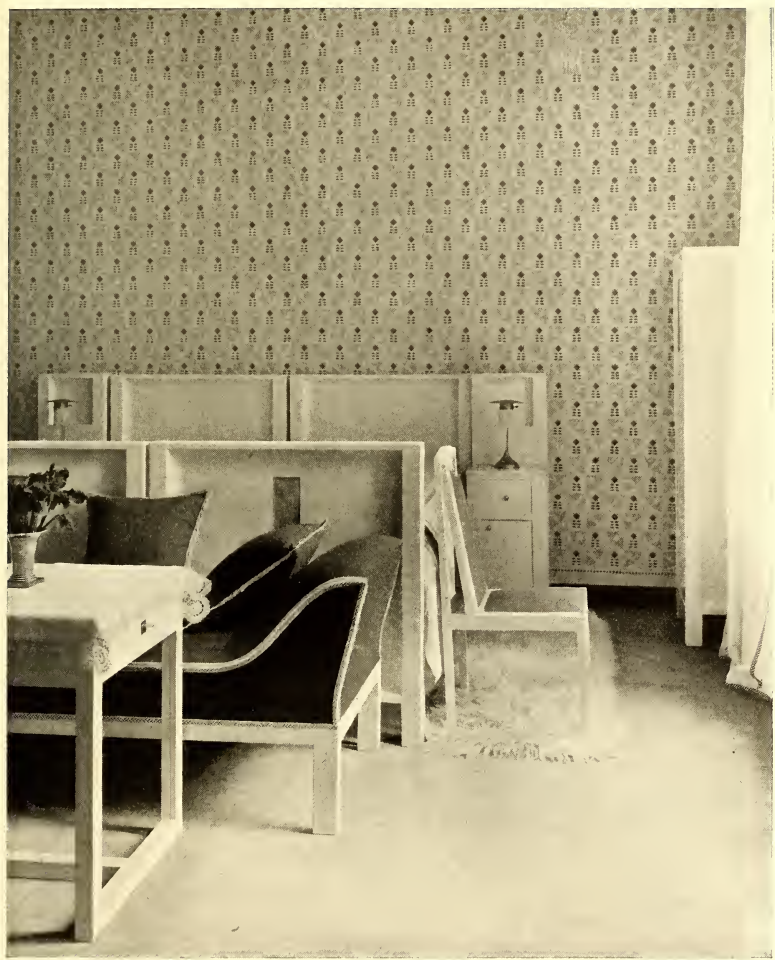

BEDROOM IN WHITE MAPLE EXECUTED BY THE WIENER

WERKSTAETTE (BY PER MISSION OF HERR HOFRAT $\mathrm{KOCH}$ ) 


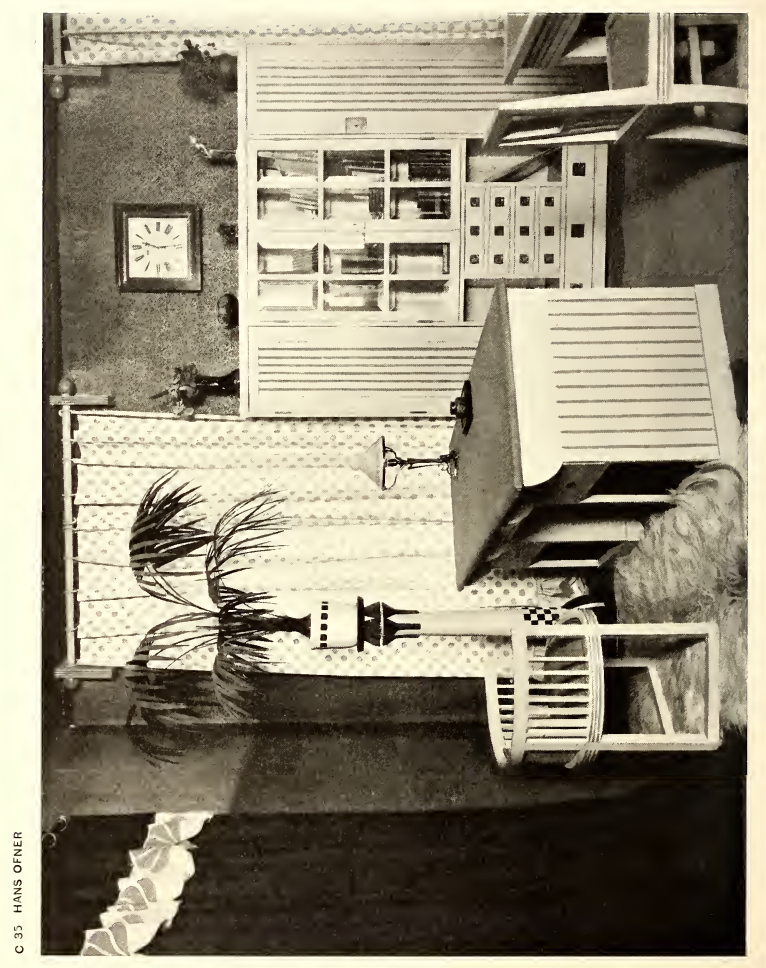

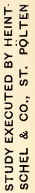




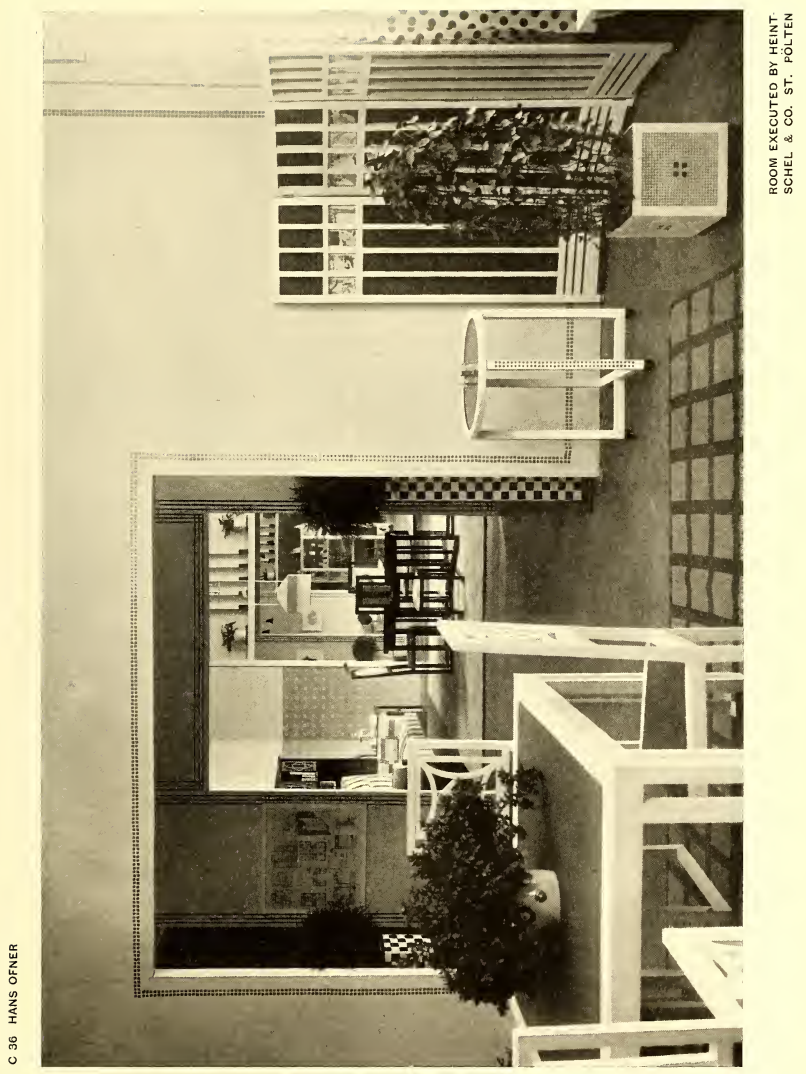




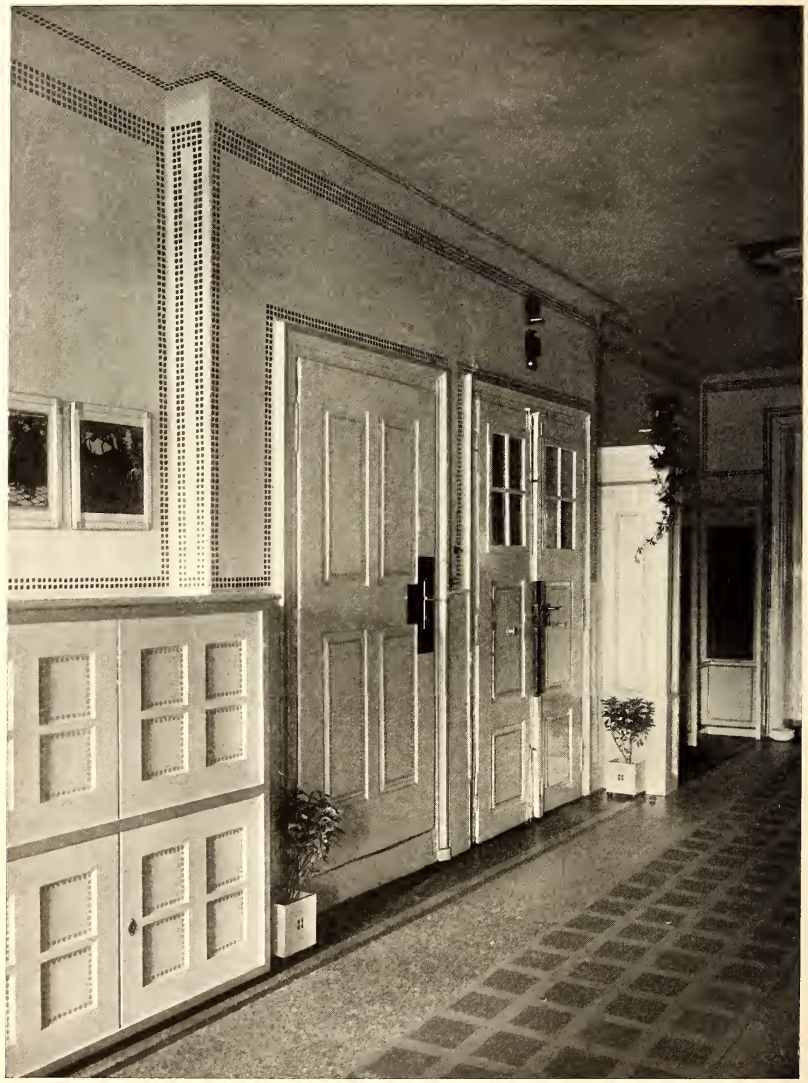

ENTRANCE HALL EXECUTED BY

HEINTSCHEL \& CO, ST. PÖLTEN 


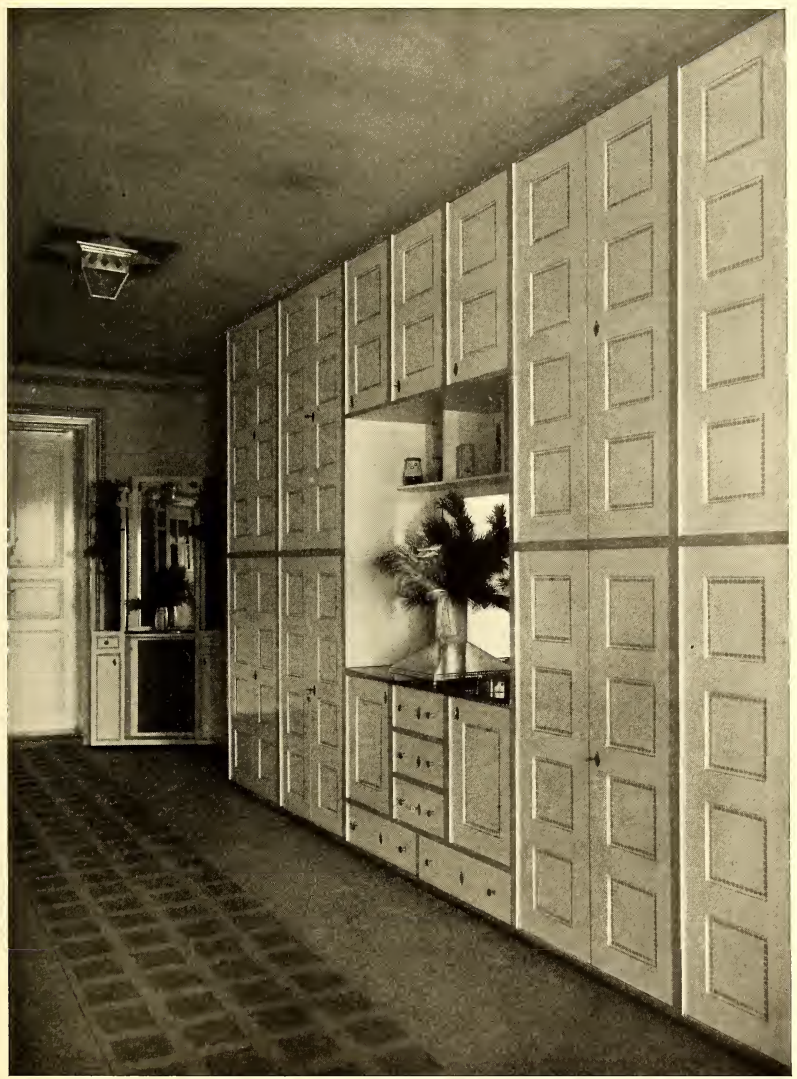

ENTRANCE HALL EXECUTED BY HEINTSCHEL \& CO., ST. PÖLTEN 


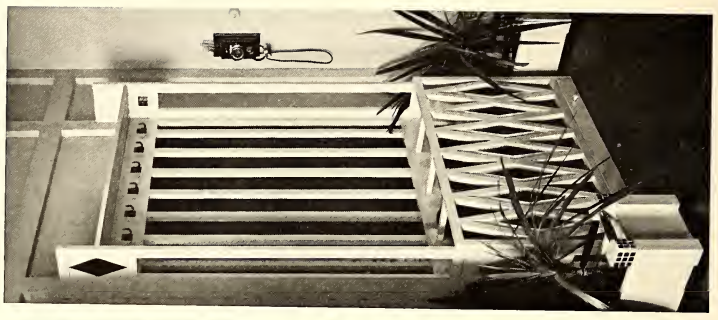

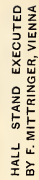

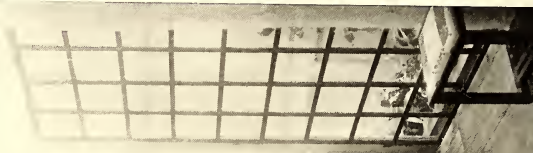

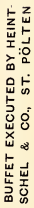

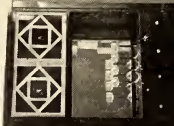




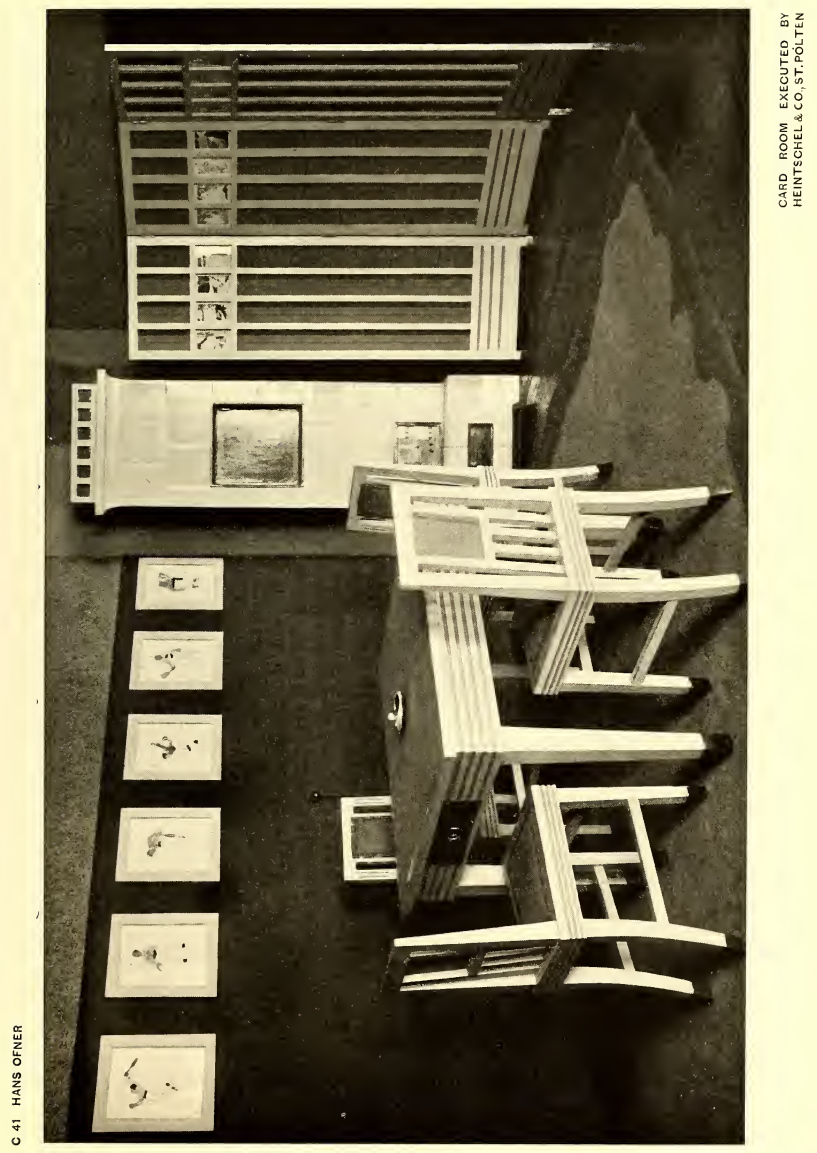




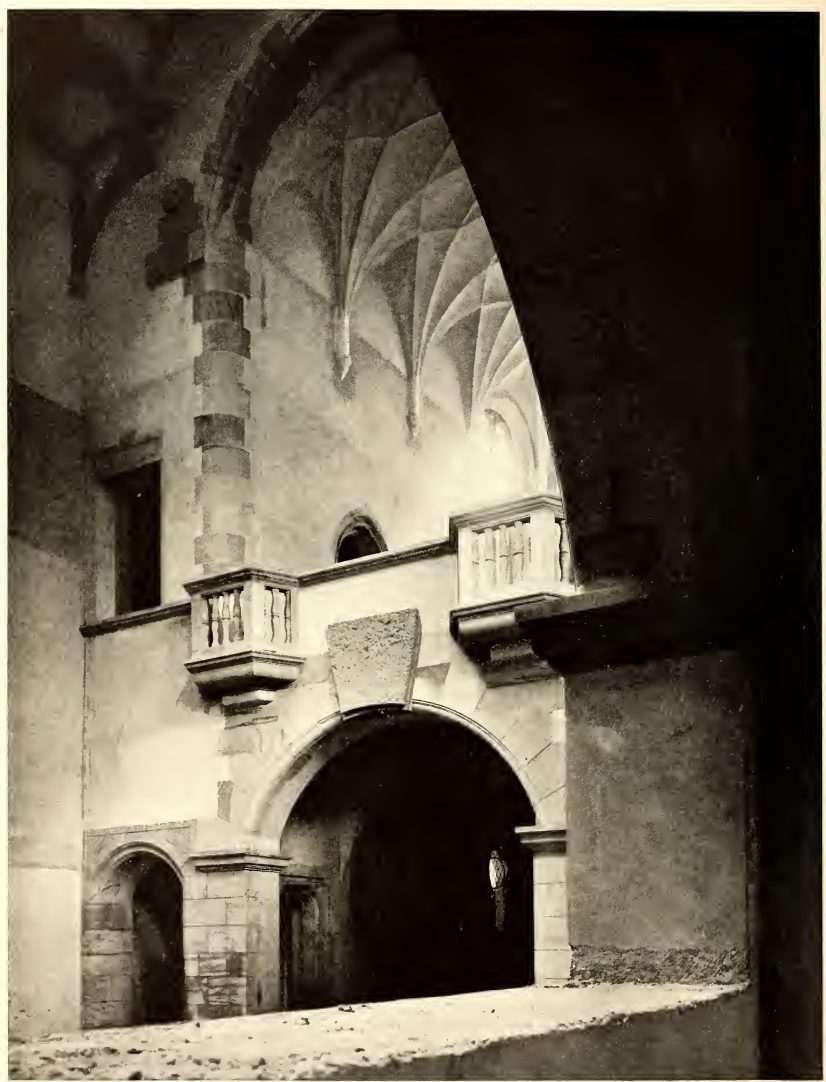

THE HALL OF ANTIQUITIES AT MAGDEBURG (BY PERMISSION OF ANTON SCHROLL \& CO., VIENNA) 


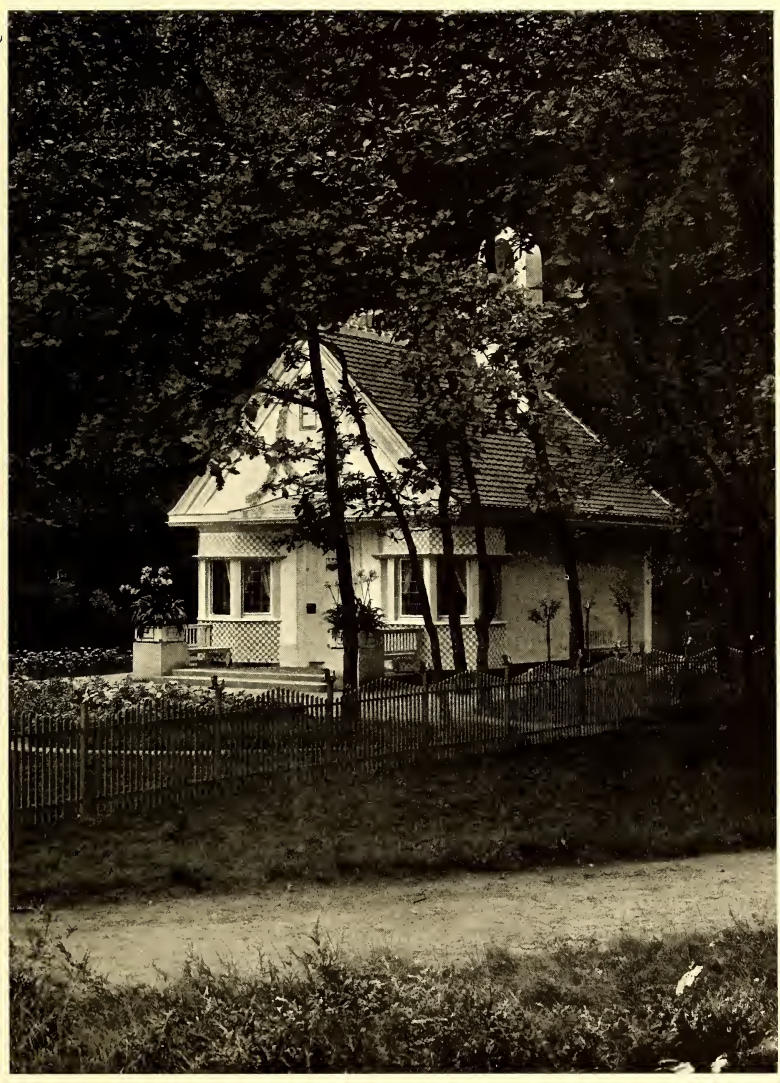




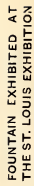

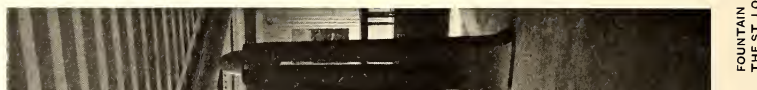




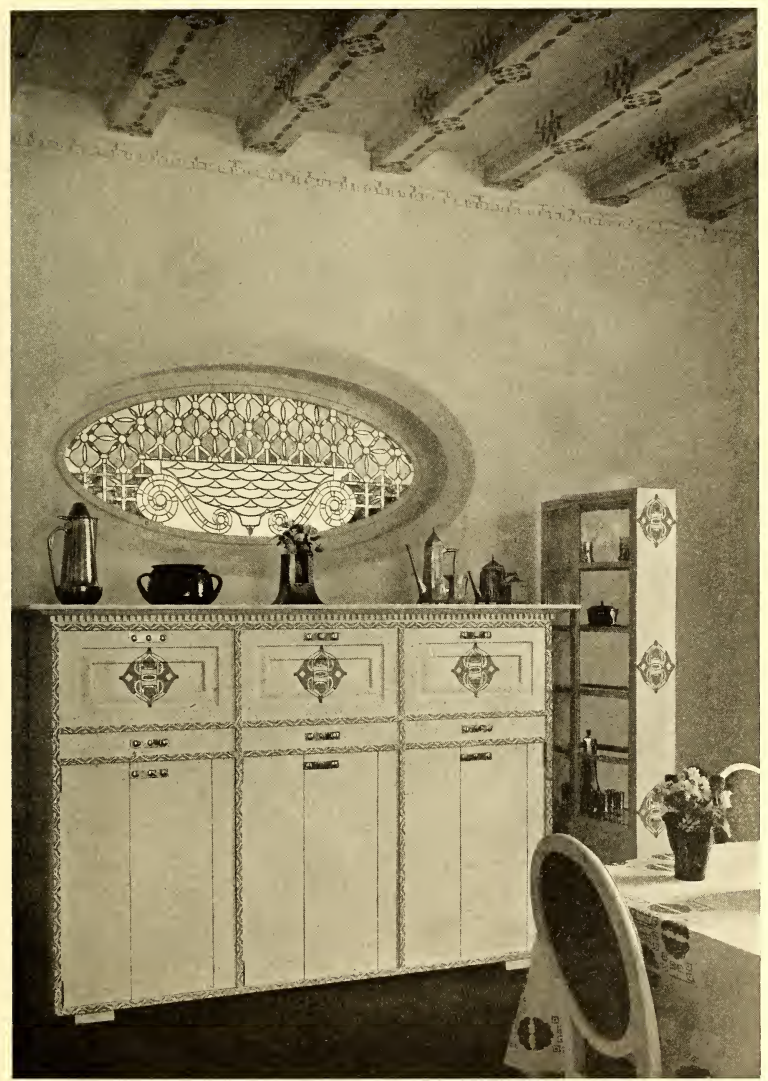

DINING-ROOM IN THE HOUSE OF

THE CHAPLAIN-IN-ORDINARY TO

THE GRAND DUKE OF HESSE 


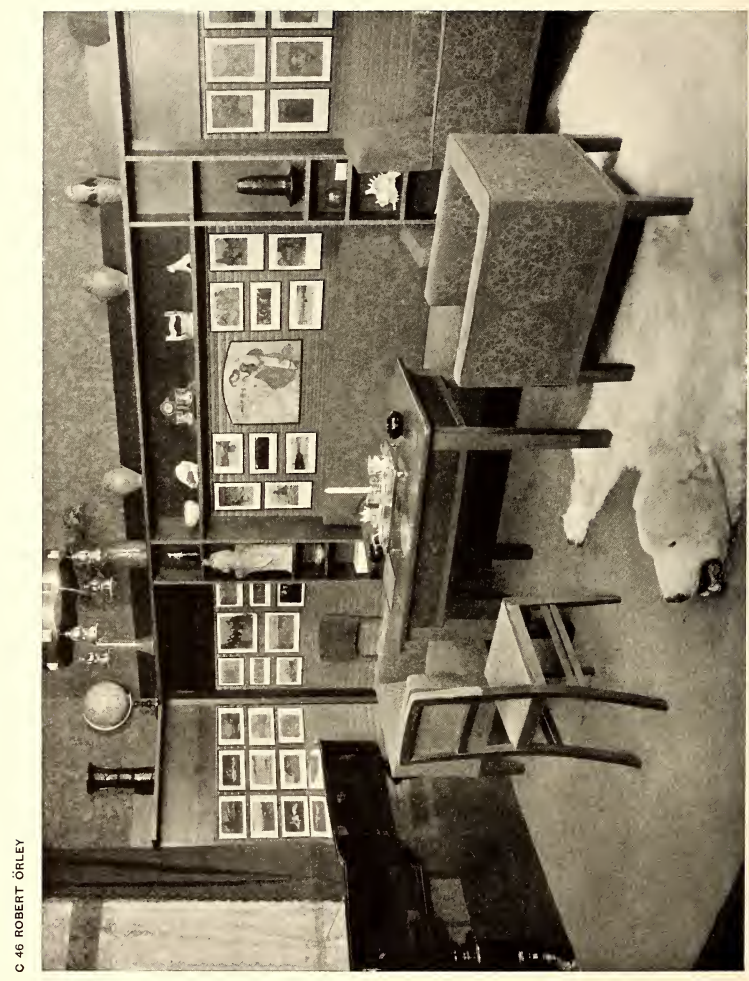




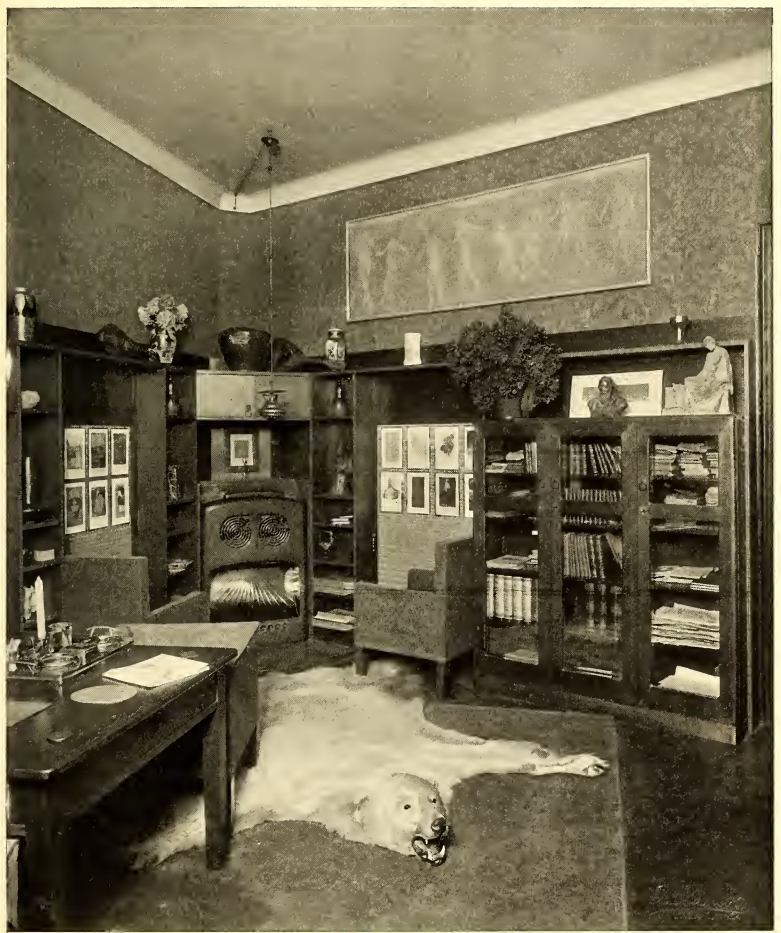




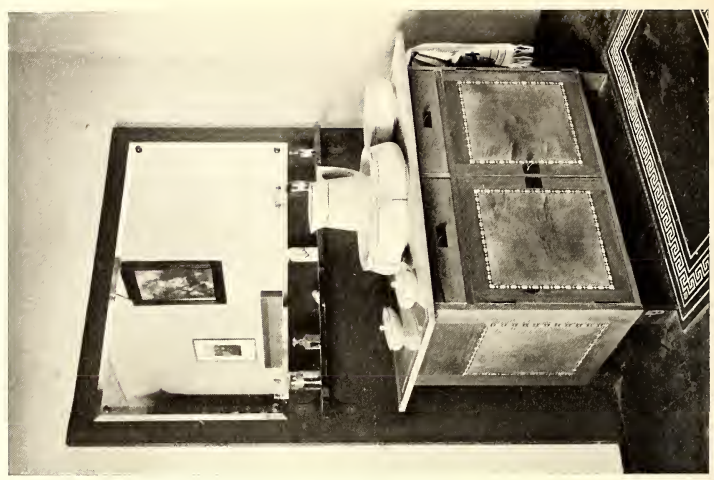

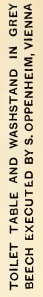

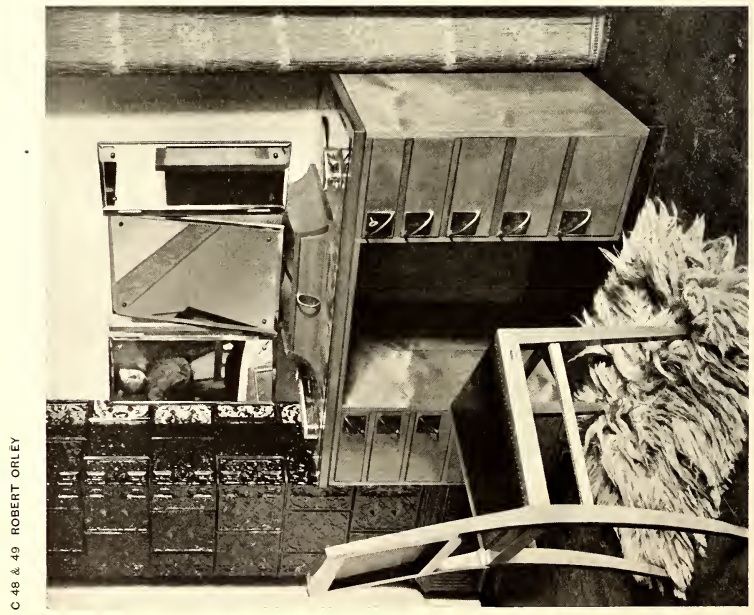


C 50 OTTO FRUTSCHER

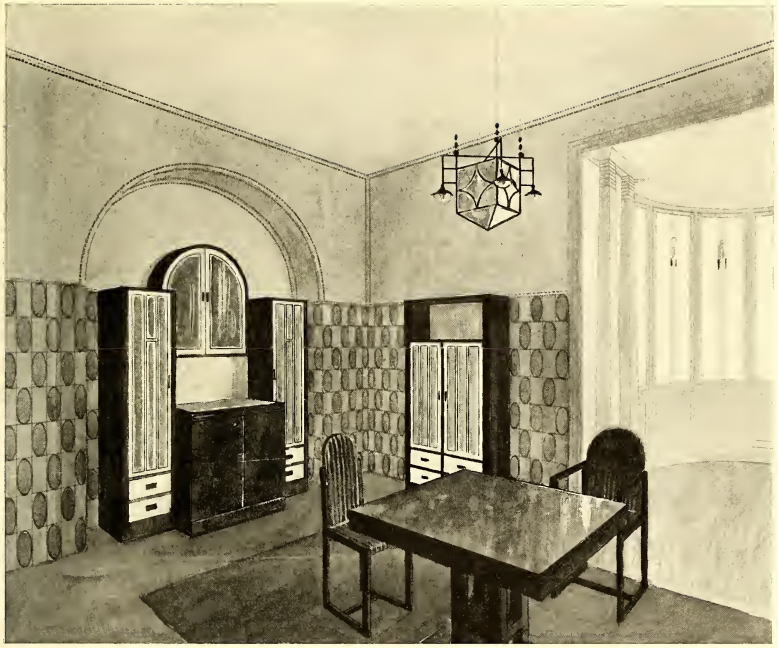

DINING ROOM EXECUTED

BY JOHANN SEIDL, VIENNA 


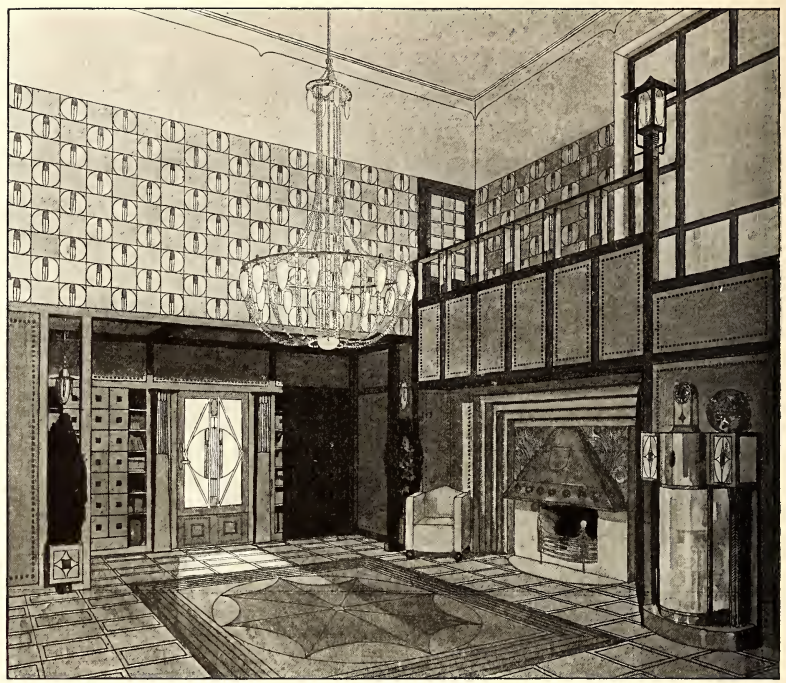




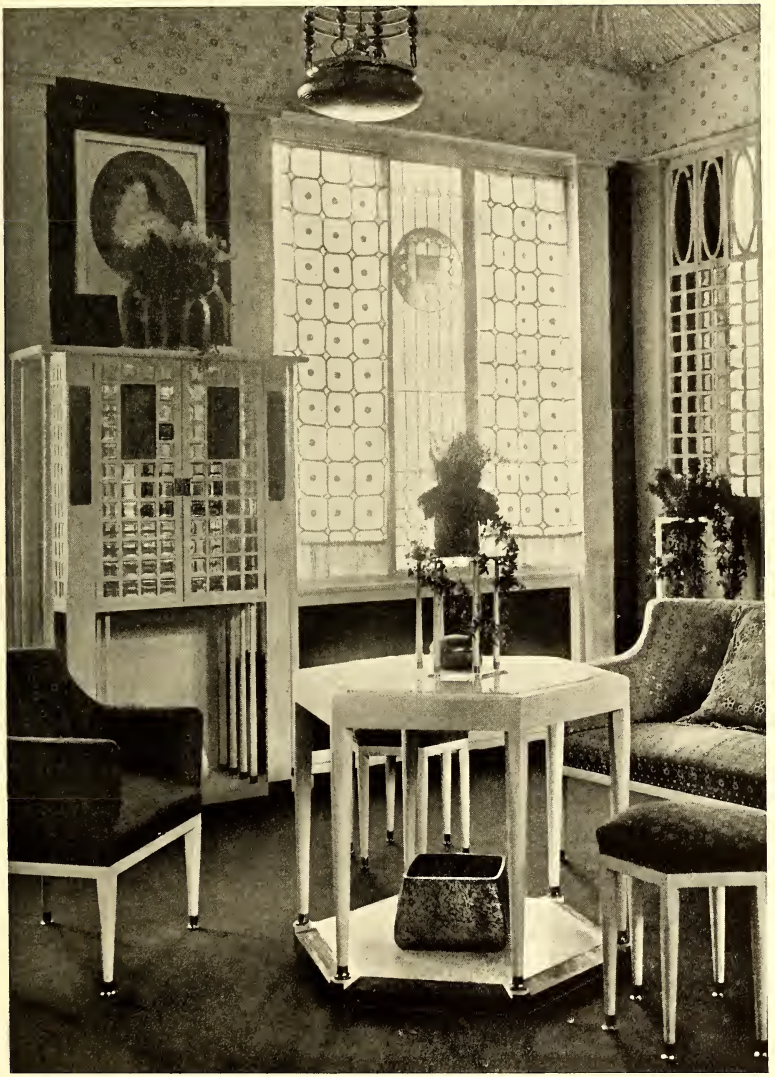

SITTING ROOM. FURNITURE EXECUTED BY L. BERMANN, VIENNA. TEXTILES BY C. GIANI JUN., VIENNA 
C 53 OTTO PRUTSCHER

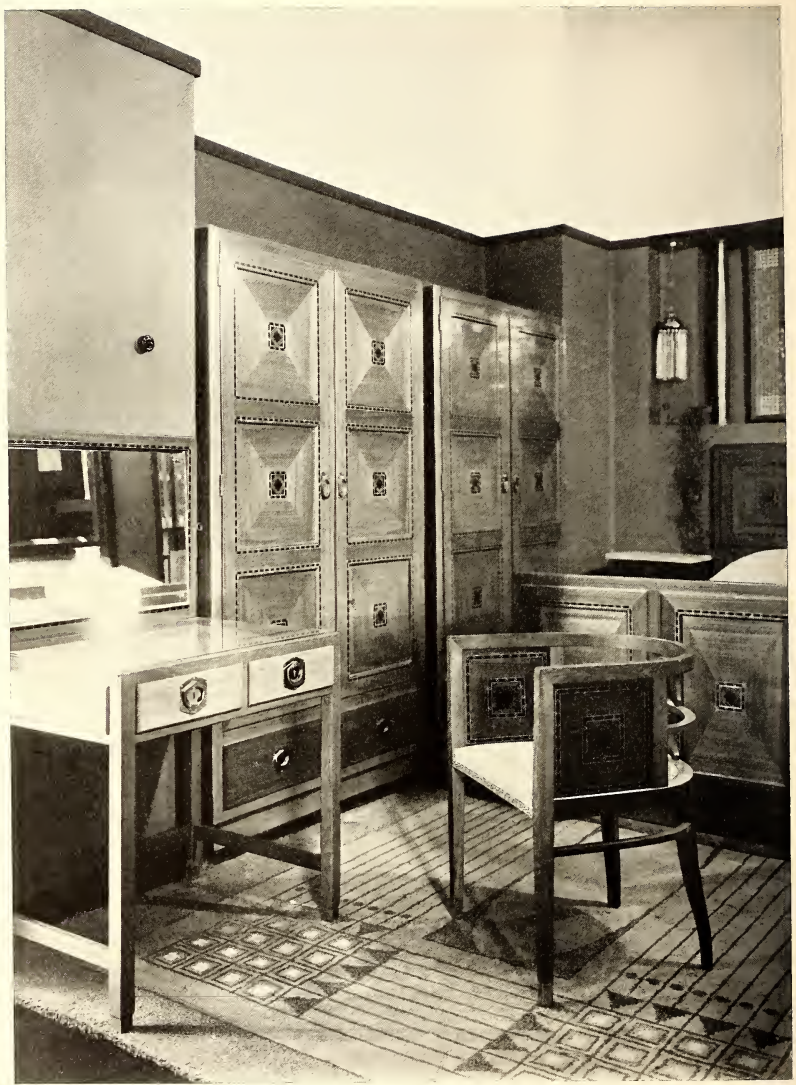

BEDROOM IN ELMWOOD INLAID WITH MAHOGANY AND EBONY EXECUTED BY A. POSPISCHIL, VIENNA. CARPET BY J BACKHAUSEN \& ¿SONS, VIENNA 


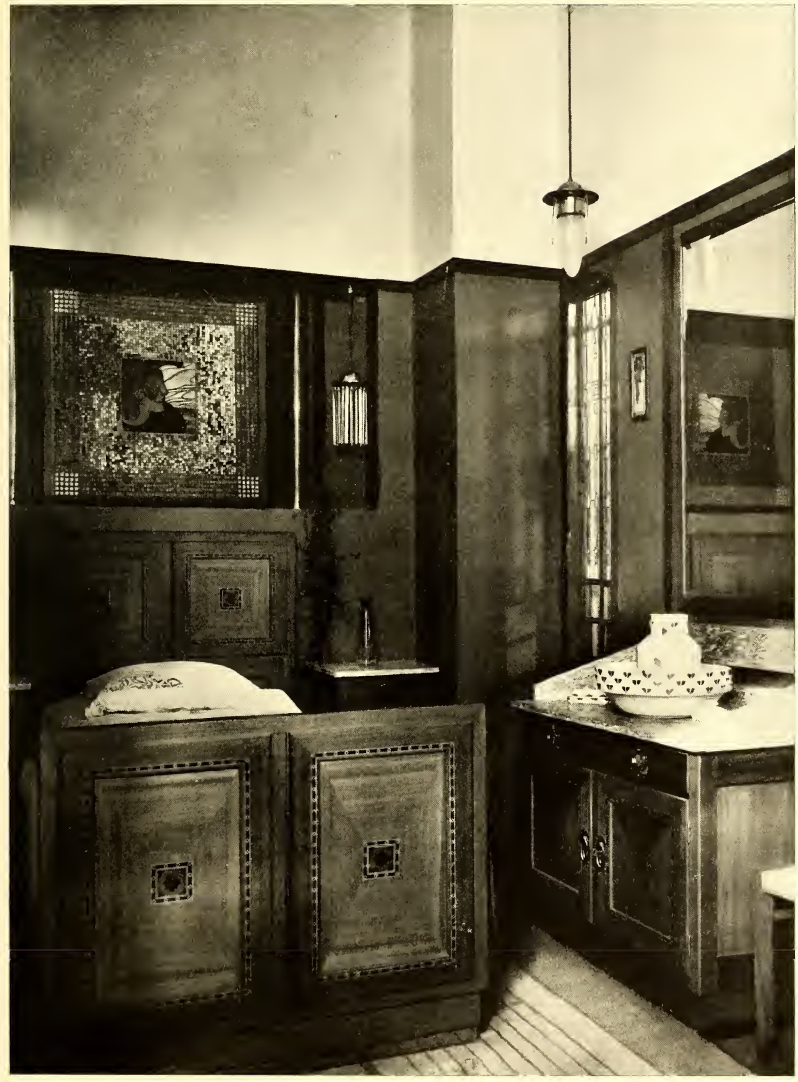

BEDROOM IN ELMWOOD INLAIJ WITH MAHOGANY AND EBONY EXECUTED BY A. FOSPISCHIL, VIENNA MOSAIC EXECUTED BY REMYGIUS GEYLING VIENNA 


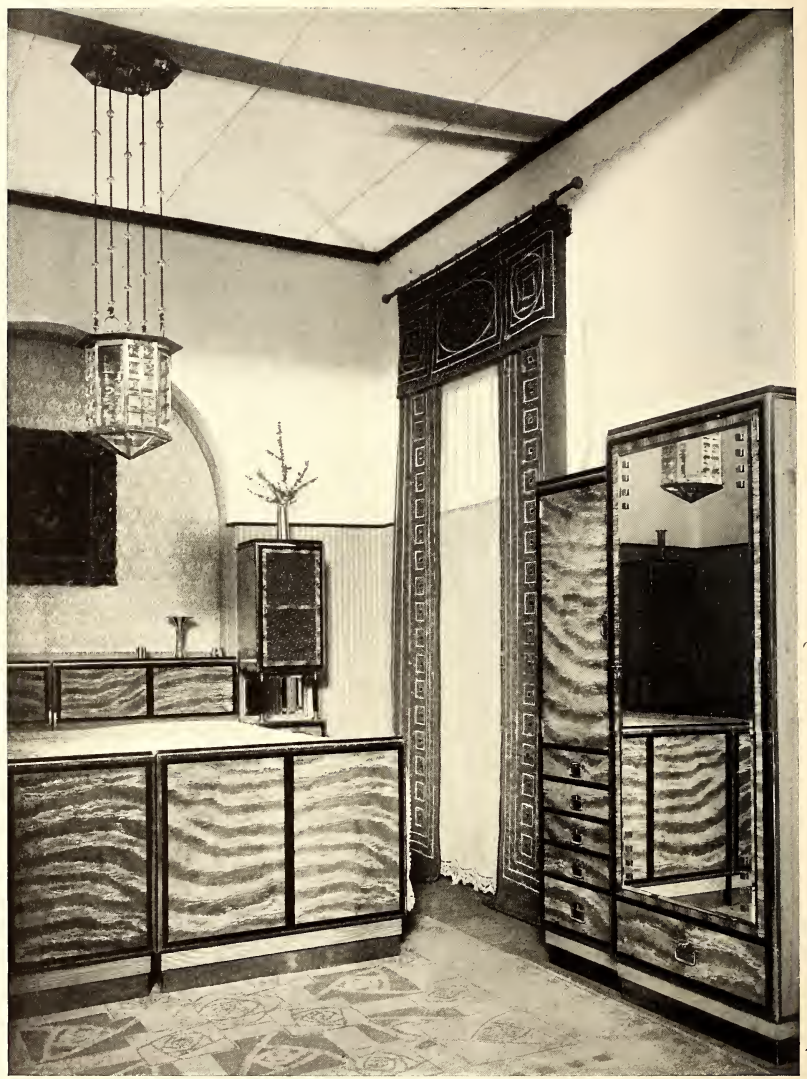

BEDROOM IN ASH AND EBONY EXECUTED BY CARL PRÖMMEL, VIENNA. CARPET BY J BACKHAUSEN \& SONS, VIENNA. LUSTRE BY BAKALOWITS \& SONS, VIENNA 


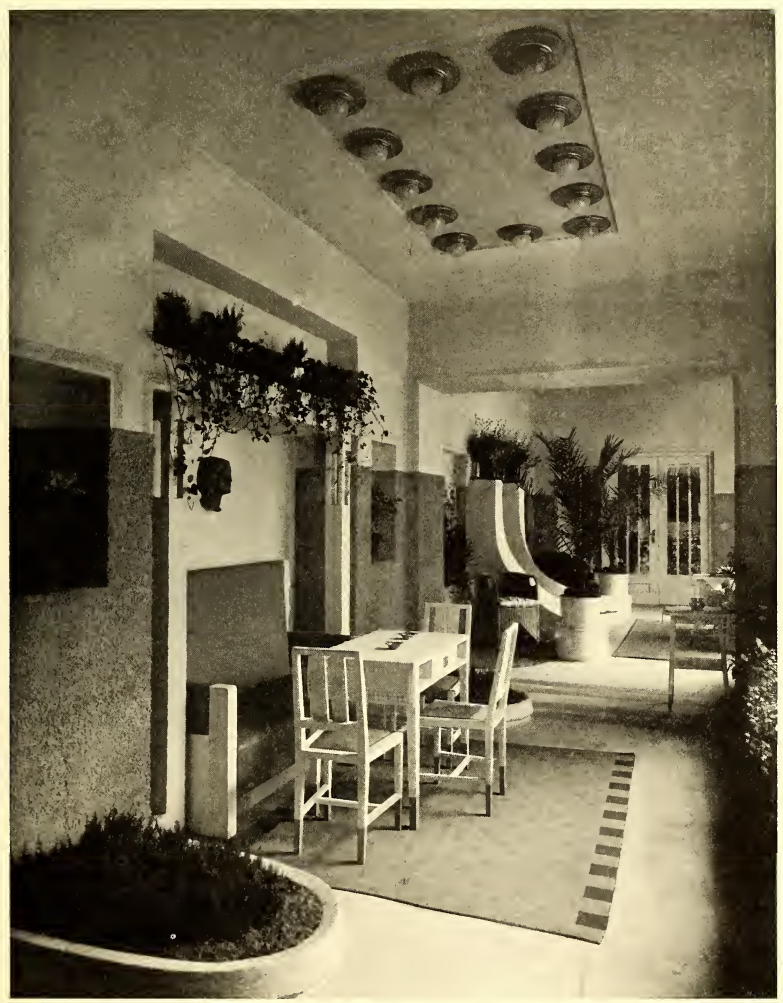

WINTER GARDEN. FURNITURE BY PRAG-RUDNIKER KORBFABRICATION, VIENNA 
C 57 JOSEF URBAN

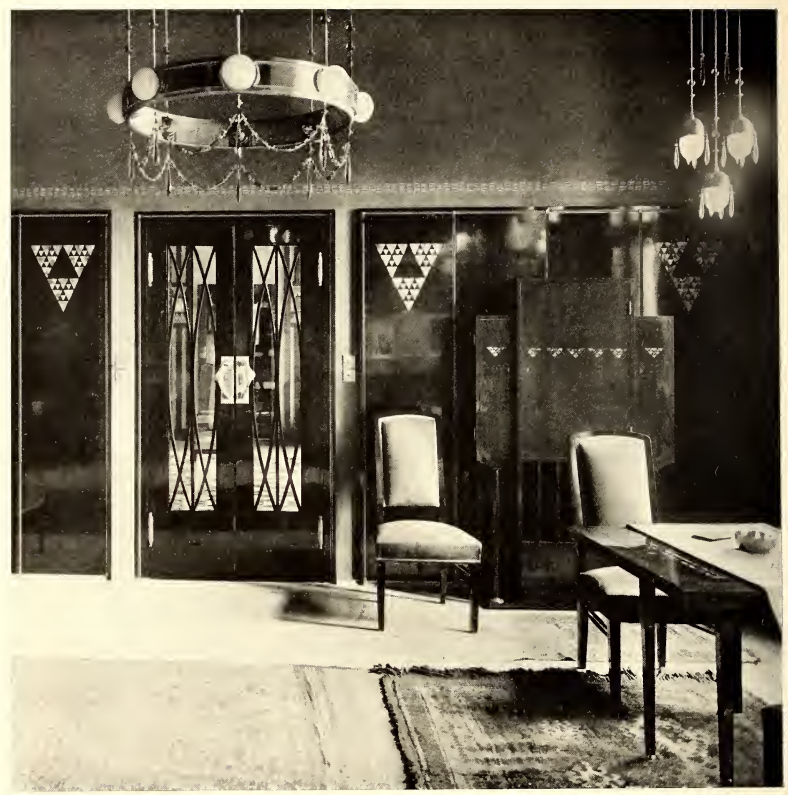

DINING ROOM IN MAHOGANY

INLAID WITH MOTHER-OF-PEARL

EXECUTED BY HOLLMANN,IVIENNA 


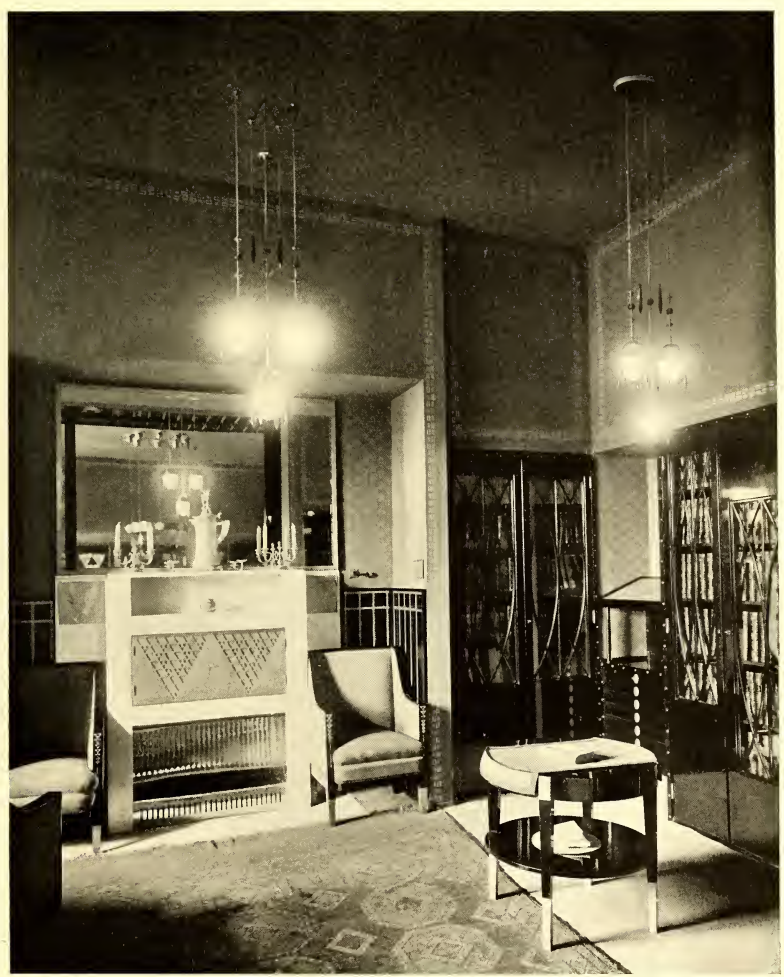

LIBRARY IN MAHOGANY INLAID

WITH IVORY AND MOTHER-OF-

PEARL. OLD SILVER FITTINGS

BY S. JARAY, VIENNA. LUSTRES

BY BAKALONITS \&"SONS, VIENNA 


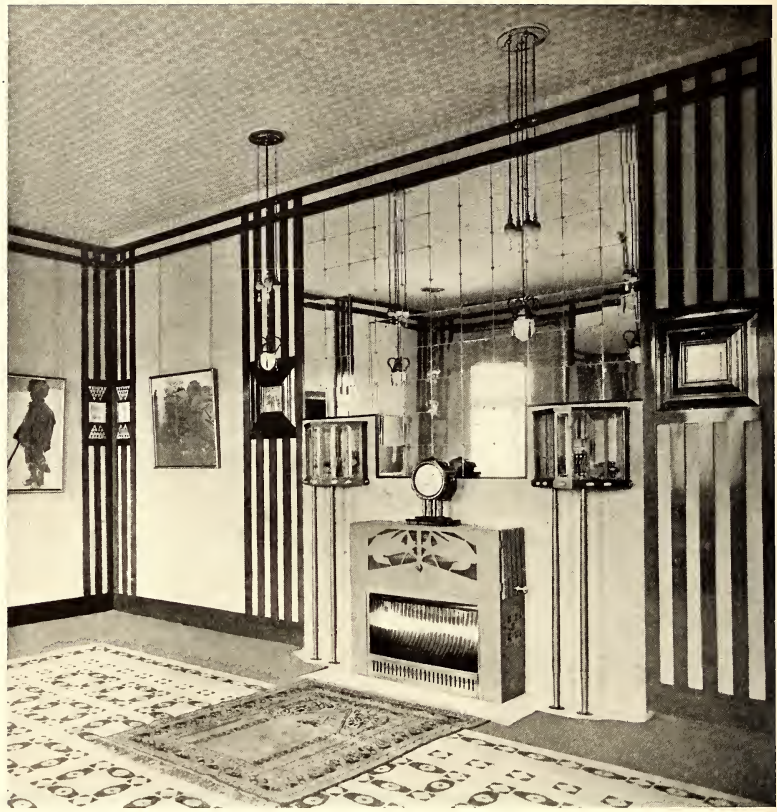


C 60 \& 61 JOSEF URBAN

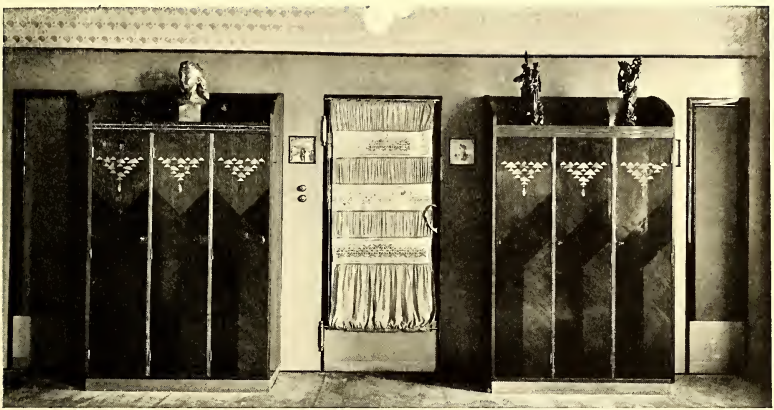

MUSIC ROOM IN NATURAL MAHOGANY. EXECUTED BY HOLLMANN, VIENNA

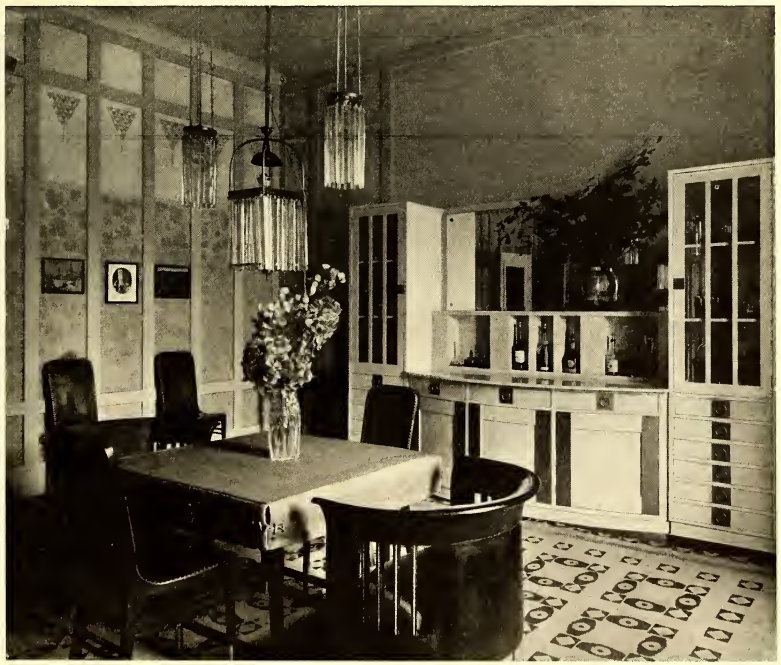

DINING ROOM. WALLS WHITE ENAMEL WITH PAINTED DESIGN. FURNITURE IN BLACK MAPLE WITH SILVER FITTINGS, EXECUTED BY HOLLMANN, VIENNA LUSTRE BY BAKALOWITS \& SONS, VIENNA. CARPET BY GINSKY MAFFERSDORF 


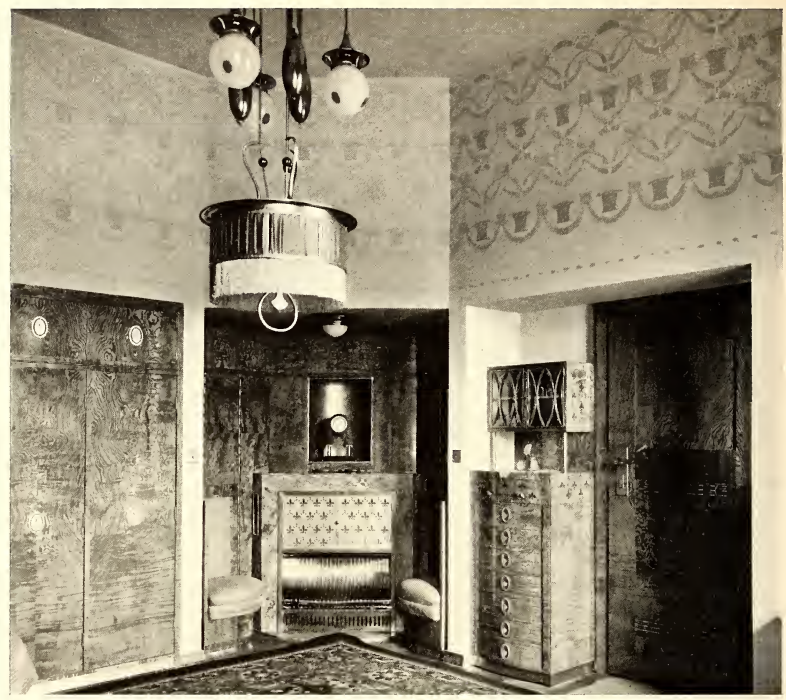

SITTING ROOM IN HUNGARIAN NATURAL OAK WITH GILDED FITTINGS AND WALL HANGINGS OF EMERALD GREEN AND RED SILK. EXECUTED BY SANDOR JARAY VIENNA. ELECTRIC PENDANT DESIGNED BY OTTO PRUTSCHER, EXECUTED BY BAK\& LOWITS \& SONS,'VIENNA 


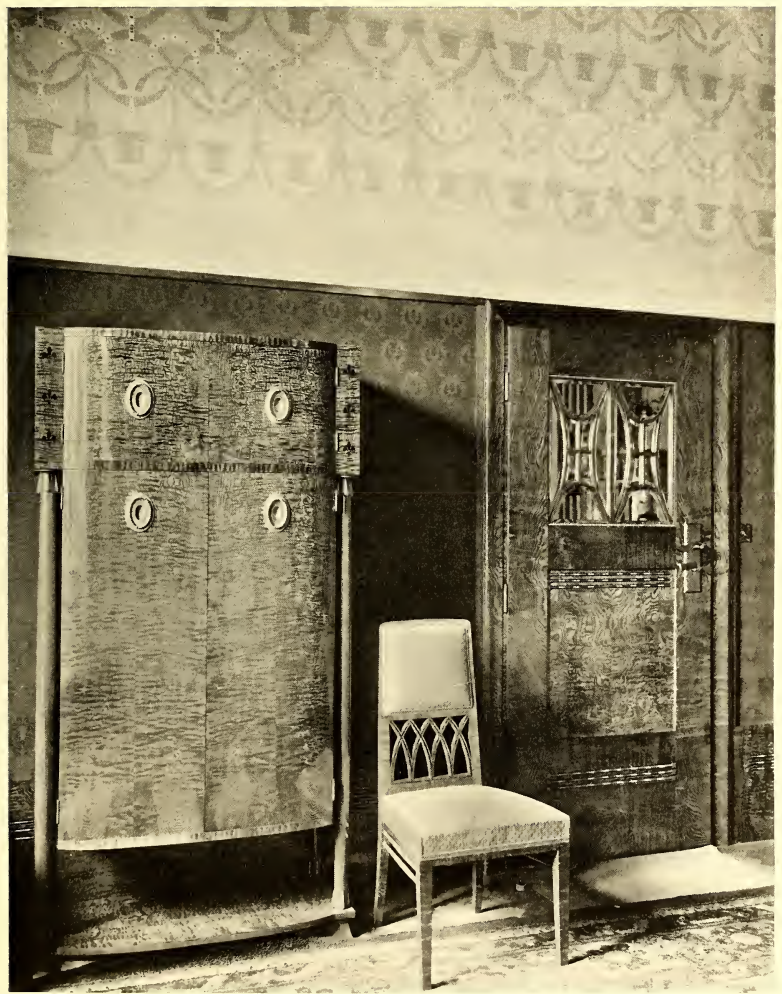

SITTING ROOM IN HUNGARIAN NATURAL OAK WITH GILDED FITTINGS AND WALL HANGINGS OF EMERALD GREEN AND RED SILK. EXECUTED BY SANDOR JARAY, VIENNA 
C 64 JOSEF URBAN
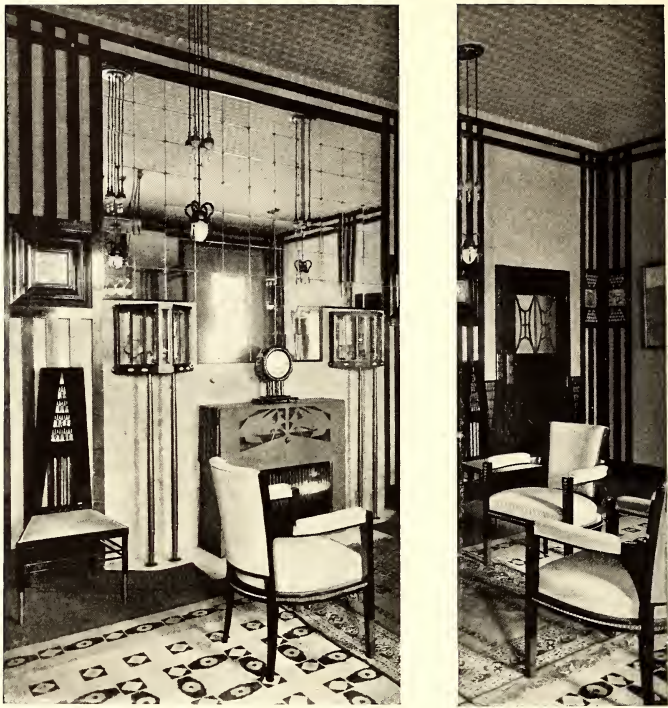

BOUDOIR. EXECUTED BY SANDOR JARAY, VIENNA FUR 


\section{MODERN DECORATIVE ART IN AUSTRIA BY A. S. LEVETUS}

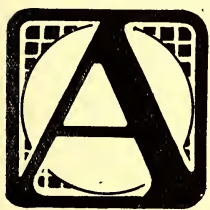

TRUE feeling for art and decoration is inborn in the Austrians. Their national art is sufficient proof of this. But the modern movement in decorative art owes its inception to outside influence-to England ; its development, however, comes from the Austrians themselves. Even before Hofrat von Scala held that memorable exhibition at the Austrian Museum during Christmas, 1897, where he showed nothing but the best English furniture and household effects, Chippendale, Sheraton, Heppelwhite, and others, the young Austrian artists had long felt that nothing but an upheaval could bring their art out of the slough into which it had fallen. They had become mere copyists of old and senseless forms; they were young, and living in a progressive age they realised the necessity to express that which they inwardly felt.

But there were other factors besides this exhibition which led to the upheaval. Just about the same time a young architect, Adolf Loos, a Viennese who had travelled much and lived in America and England, returned to his native city, and through the medium of the "Neue Freie Presse" expounded his views on men's clothing, furnishing and decoration. The interest he aroused helped to create a desire for better style, and in the shop windows were displayed articles which were more or less echt-englisch.

Naturally there was danger that the Austrians would again become mere copyists, but of another style. Luckily all fear soon passed away. Out of Professor Wagner's school of architecture a number of young architects came, men of intelligence and capability, filled with a burning desire to show what they could do. They were conscious of their power, for, as in modern architecture so in modern decorative art, Otto Wagner was the leader. He filled his students with his enthusiasm, but he in no way sought to restrict them; and therein lies his greatness. Freedom of thought to all, based on a firm scientific foundation, might well be his motto. And long before there was any outward expression of the new movement in Austria 
"The Studio" was unostentatiously but surely doing its work there as in other countries besides England. As Herr Muthasius said in his lectures on the "English Home," given at the Austrian Museum a few weeks ago, "The Studio " led the way to a new order of things by resolutely showing only that which was best.

But a struggle followed, for it was not easy to change the order of things. There were fears that the Austrian style (sic) would be lost. The authorities forgot that the fine Biedermaier period had long passed, giving way to commonplace imitations, which they were only too anxious to preserve.

Finally, in the Spring of 1897 , the "Secession" was founded. It needed an upheaval to bring about a complete change, but even at the first exhibition held by this society promise of a great future was shown. The word "Secession" caught fire; everything outré bore the title "secessionistisch," and as in painting and architecture there were true and false Klimts and Otto Wagners, so in the arts and crafts there were true and false secessionists. But what a world lay between the two! The stranger coming to Vienna, who knew nothing of Josef Hoffmann, Olbrich, Koloman Moser, Plecnik, Leopold Bauer, Jan Kotéra, Adolf Böhm, Roller, Krauss, and other secessionists in the arts and crafts, must have shrunk from "Secession" with a feeling of horror that in a city famous for art such "un-art" should be found, and longed for those bronzes, leather goods, porcelain and other objets d'art for which this historic city had long been celebrated. "Secession" has survived this, for it is no longer a by-word, but one to which all honour is due. Even the split has made little difference in this respect. The "Secession" has done most to bring about the modern development in the arts and crafts ; it showed what other nations were doing, and introduced, among others, the Belgian, English, and Scotch schools to Vienna. Oddly enough, the two latter appealed most to men like Hoffmann and Moser, for while Van der Velde found footing in Germany, Ashbee and the Mackintoshes were preferred in Austria, though Olbrich followed in the footsteps of the Belgians. Out of these foreign elements has arisen a true Austrian style, which has gradually but surely developed during the last eight years.

The appointment in 1899 of Baron Felician Myrbach as Director of the k.k. Kunstgewerbe-Schule (Imperial Arts and Crafts School) was a step in the right direction, for he had travelled much, and had lived and studied art in Paris. He was a man of large ideas, conscious of the strength of his staff, which numbered many able men-Josef Hoffmann, Alfred Roller, Koloman Moser, Árthur D ii 
Strasser, Rudolf, Edler von Larisch, and, later on, C. O. Czescka -all young and earnest men, great both as artists and teachers. Their appointment marked a new era in Austrian decorative art. What this Kunstgewerbe-Schule has done for modern art in Austria can already be seen, for every year it is sending forth a number of new men eager to prove their ability. Some few manufacturers have helped, and all honour is due to them, but here again practically unsurmountable difficulties had to be contested. Many of these manufacturers had been accustomed to get designs for nothing; silver had been sold per weight, with no additional sum for the artistic design; who could have thought that the work of the artist would also have to be taken into account? Such things were practically unknown; why should the old régime be changed ? This struggle is still going on, and is likely so to do ; the public are at fault, for they desire cheap things, and in the search for cheapness the artist is too often forgotten.

But in spite of all this there is a general desire on the part of the educated public to employ the architect for the furnishing and arrangements of the home-though means do not always allow this. There are several good men in Austria, men of many and varied talents, who have produced good work and helped to stimulate activity in art. Fortunately, too, there are capable workmen, for in cabinet-making especially Austria is to the fore. The workmen have a true love of work, and delight in the expression of the artist's fancy, especially in fine intarsias, mosaics, and other inlaying. The finish is admirable, and it is no wonder that such men easily find employment in foreign countries.

But it is not always easy for artist and workman to keep in touch with one another, and it was with a desire to span the bridge which necessarily exists, where the artist makes designs for the manufacturer and for various reasons is allowed no further interest in them, that the Wiener Werkstaette was founded last year, with Professor J. Hoffmann and Professor Koloman Moser as artistic directors. It is not given to every man to see his ideals fulfilled, but these two professors are among the fortunate few. They are both men of great versatility and capable of achieving what they have set before them as their task. Hence their success. Professor Hoffmann's great aim is to follow in the footsteps of Ruskin and William Morris, to create a home of art in $V$ ienna, and so bring about a right feeling not only for the artist but for the craftsman who breathes life into the artist's work. Some of the young artists who are trained at the Kunstgewerbe-Schule are employed by the Wiener Werkstaette; the seeds have been sown 
well, and, from an artistic point of view, great success has been achieved. And that is what concerns us here.

Utility is the first condition, but there is no reason why the simplest articles of household effects should not be beautiful. The value does not lie only in the material, but in the right thought and treatment of the material, and its power to convey that thought to the minds of others, to convince them. This is no easy task. What it is capable of producing the Wiener Werkstaette has already shown. The new Sanatorium at Purkersdorf, near Vienna, which was designed by Professor Hoffmann, is a convincing proof of what may be achieved by the united aid of artist and workman working together in harmony for a common cause. With the exception of the textiles-which, however, were designed by Professor Hoffmann -and the kitchen utensils, everything was made by the Wiener Werkstaette, including the building itself. The interior is very refreshing, from the roomy hall, where Professor Moser's fine glass window may be seen, to the living and bed-rooms above and the kitchens below. Professor Hoffmann has a predilection for white and black. What might appear monotonous by mere description is not so in reality; the lines are harmonious and restful, and the distribution of light everywhere is admirable, for the professor is too great an artist not to be mindful of every detail. There are billiard, card, reading, and music rooms, and salons for ladies and for gentlemen, as also a joint drawing-room. There are also bath-rooms for every possible treatment, for a sanatorium has something of the nature of a hydro. There is no superfluous ornamentation, neither is there too little. The chief beauty lies in that due proportion which is so prominent a feature in Professor Hoffmann's works. Nowhere has he shown this better than in the Sanatorium; at every step something new is presented to us, something that appeals to our finer feelings. Everything was designed by Professor Hoffmann except the salons, and these emanated from Professor Koloman Moser, who shows here, as always, a fine feeling for colour ; indeed, he is a great colourist in the arts and crafts.

Professor Hoffmann's lines are more severe; each room has its special characteristic, and here we can learn the lesson of the artist's ideals. Their further development will be seen when the villa which the Wiener Werkstaette is building for M. Stoclet in Brussels is finished. What are the artist's ideals? These may be gathered from his works, which, though not written, speak a language to us. From them too we gather where his strength lies, namely, in utility combined with structural beauty, a quick eye combined with real intellectual $\mathrm{D}$ iv 


\section{MODERN DECORATIVE ART IN AUSTRIA}

ability, a creative power combined with right judgment for the exercising of it, a love of form combined with the power of right adjustment, and a special gift for the practical. How far-seeing he is can be gathered by the dressmaker's salons he has fitted up for the Fräuleins Flöge. The show-rooms are veritable homes of art, there is nothing obtrusive and no detail has been forgotten. Everything has its due place even to the electric lamps on the ground arranged to give light for the adjustment of the customer's gown. Indeed, these salons are essentially serviceable and artistic. To him the artistic value is the same, whether it be the simplest article of everyday use or the most expensive ornament. In everything it is the thought underlying all which is of the greatest value; hence he can have none but thinkers around him. His workmen must be in sympathy with the artist whose ideas they are executing, not merely perform their work in a perfunctory manner. He has given them artistic workshops, he recognizes that their work too is noble, and that only when they give what is best in them will they be ennobled and refined by their work and worthy of their hire. He has travelled much and seen much, he knows what other nations are producing in art, and is jealous for his own country. He has also given much care to the solving of the bent-wood and wicker problems in furniture, in which he has been ably supported by Messrs. J. and J. Kohn, and the Prag-Rudniker Korbwaren Fabrication, Vienna.

Professor Moser is also a man of manifold powers. There is hardly a branch of applied art to which he has not turned his hand. He has studied, too, in workshops, in glass manufactories, in textile and other manufactories, and everywhere has gained knowledge, and the experience gained he has put to good use. To know the value of the materials in which a design is to be executed-their intrinsic value-means much to the artist. Like all the men of the modern school, he has an eye to utility, for utility should be the basis of all applied art, and therefore it is for this reason that he has given so much attention to the articles of everyday use, even beyond such as are made in the Wiener Werkstaette. The glass designed by him has won praise outside his own country ; the latest development is the application of the square-a prominent feature in both Professor Hoffmann's and Professor Moser's designs-to glass; some very fine results have been achieved, and an additional charm has been given by making all the wine-glasses and tumblers of the same height. There must be nothing to disturb the harmony; no discordant strain.

In his interiors, as in all things, Professor Moser shows the same 
right feeling. His artistic balance is well poised, both his hand and his judgment are unerring. His strength lies within himself; he, too, is a creative power, but of another genre. His mind is a fertile one, filled with rich stores of fancy; his colouring is warm but well modulated, and his taste perfect. He has evolved an art for himself-an art peculiarly his own and at once recognisable. If his designs do not show the masterly dignity of Professor Hoffmann's, yet they possess a charm and beauty revealing not only the true artist but the true Viennese.

These two men, Professor Hoffmann and Professor Moser, have created a new style in decorative and applied art, a style which is essentially Viennese; and although they have learned much from other schools, theirs bears the unmistakable mark by which it will in the future always be recognized as Hoffmann and Moser. Both men are far-seeing, and they will continue to advance. New developments are continually taking place, some branches shoot forth, others are lopped off. Each artist is a resource in himself, and each holds the future of Austrian applied art dear to him.

Professor Czescka is another power in the Wiener Werkstaette and a true artist in every sense of the word. Since Baron Myrbach's resignation he has become a teacher at the Kunstgewerbe-Schule, and his pupils are already giving evidence of his influence. His forte lies in decorative work. The casket here reproduced (D. 67) is a fine specimen of his conceptive power. It was presented to the EmperorKing Franz Josef by Messrs. Skoda \& Co., the torpedo manufacturers, and has been lent by his Imperial Majesty for the exhibition now being held in London. It is 53 centimetres long, $37 \frac{1}{2}$ wide, and 20 high. The fourteen columns are supported by ivory feet. These divide the sides into ten panels bearing seven different designs. In the middle one is seen the Imperial arms specially arranged for this purpose by the professor. The panels to the right and left show two men-of-war armed by Messrs. Skoda and borne along the waves by sea monsters. All the designs are beaten into the silver, which is richly gilded over. The lining is formed of silk braids of yellow and black, the Imperial colours. The casket is a veritable work of art, both in design and workmanship, and was made by the Wiener Werkstaette.

Frau Elena Luksch-Makowsky is a strength in herself. Her designs, be they for beaten metal work, ornaments or ceramics, show precision, beauty of conception, rich and fertile imagination, and sure technique in expression. She possesses varied talents, and her work is always interesting. In all that she does, whether great or D vi 
small, there is underlying truth. There is power and there is character in her work, a delight and a surety which are convincing of her real love for it.

Professor Olbrich, from his adopted home in Darmstadt, exercises his influence chiefly in Germany. His noble designs, simple in their construction as they appear to the uninitiated, bear the impress of a great mind. Like Professor Hoffmann, his strength lies in construction combined with rare beauty and simplicity of form. His interiors show deep thought and intense feeling for what lies before him. All he has created gives evidence of his richness in ideas nobly conceived and nobly executed.

Leopold Bauer, who is a leading member of the "Secession," and holds a foremost place both as an architect and decorative artist, began his career by throwing off all traditions. This may be seen in his architecture as well as in his interiors, and the results were highly satisfactory to those interested in the modern movement. He met with much success. His first intérieurs show the influence of the quadratic in ornamentation which is so prominent a feature of the modern Viennese school. Later his opinions changed, and he came to the conclusion, not without much thought, that all development must proceed in natural order. For this reason he is little influenced in his later work by foreign schools of decorative art. He feels that the architect is not supreme in the arrangement of a home, that in decorating he must take into account the persons who are to inhabit it, that they must feel that it is really a home. We all love certain treasured articles in our homes, and cling to them for the memories they recall. Such are our friends, and were they banished by the dictatorial architect, it would cause us pain. Leopold Bauer understands this, and attempts nothing radical. The favoured piece shall have its right place, due respect must be paid to it. Yet his interiors do not suffer from this liberality of thought and judgment, for he has too fine a sense of rhythm to allow this to jar, the harmony is still preserved, but the old form is the key-note for the orchestra which is to fill the room with beautiful music. In this lies Bauer's success. He understands his art and he understands man. His interiors bear the stamp of intimacy. This Bauer aims at, and this he achieves.

Jan Kotéra is a Bohemian and lives at Prague. As a decorative artist he has gained much fame. His art necessarily differs from that of the Austrians, for the natures of the peoples are different, and the nature of a man is expressed in his work. He is a true Wagner disciple, accurate and just, and possesses a fine feeling for form. 
Josef Urban is a leading member of the Hagenbund Society, and generally arranges its exhibitions. $\mathrm{He}$ is fertile in thought, rich in imagination, and ever open to receive a lesson, and for this reason he has learned when to curb his thoughts and when to express them. $\mathrm{His}$ work has warmth of tone and a right sense of concord. $\mathrm{He}$ clothes his walls in silks and in brocades. His furniture is well thought out; there is no over-burthen of decoration, which yet has its due place. His interiors have a peculiar charm and delicacy, they are dainty but never merely pretty. They express the rhythmic swaying tones of a Strauss waltz, for he is a Viennese to the core. $\mathrm{He}$ is versatile, as are all these Austrians, with a quick eye and a rapid hand to grasp an idea and to express it. Alfred Keller is another member of the Hagenbund, and is doing good work.

Oskar Laske is the architect of the "Jungbund," and is very successful in decorative work and as arrangeur. Marcel Kammerer and Emil Hoppe are also coming men. They are pupils of Otto Wagner.

Adolf Loos believes, like Bauer, that in every home the architect should take into account, when planning the room, that ancient pieces should have their right place, but the harmony must be preserved. There is no reason why they should be banished to undignified places not worthy of them. What is to be avoided is the striking of a false note, and it lies in the artist's power to prevent this. As long as the harmony is preserved a few grace notes will not destroy it. So a lamp given by a treasured friend, a table or some other object dear to its owner, must have its honoured place. He has a preference for fine-grained mahogany, and, as all really good architects should do, chooses the woods himself. In many respects he differs radically from the other Austrian designers. He believes it is impossible to " find" new forms for chairs, and never attempts to use any but copies of real old English styles, which he considers the best in existence. And here again must a good word be said for the Austrian workmen-nowhere are there more excellent ones, and the copies made in Vienna, by the fineness of their finish, equal in beauty those made in England. Adolf Loos' walls are panelled below with spaces for pictures, while for the upper part he uses English or Japanese wall-papers. He delights in warmth, and is much influenced by English and American art in decoration.

Robert Örley has lately come to the fore as a decorative artist and architect. He studied under Friedrich Schmidt, the predecessor of Otto Wagner at the Academy of Arts. His principles are as sound as is his judgment. He aims at comfort in homes; "modern but not extravagant" is his motto. He has been much influenced by the D viii 


\section{MODERN DECORATIVE ART IN AUSTRIA}

great movement going on around him, and has known what to adopt and what to reject; and out of this he has formed a style peculiarly his own and generally appreciated. He knows the value of the study of the materials in which a design is to be carried out, and adapts himself accordingly.

Baron Krauss joined the army of moderns long after he had begun to practise as an architect and decorator. He also is a pupil of Friedrich Schmidt. As a decorative artist and architect he has made his power felt. His aim is simplicity combined with comfort. His chief work is seen in the provinces, where he has built several villas and entirely furnished and decorated them. The interior decorations of the "Bürgertheater," Vienna, which he built and decorated, show that it is possible to have artistic arrangements even when the money -an important but unfortunately necessary factor -is limited.

Otto Prutscher, Hans Ofner, Franz Messner, Wilhelm Schmidt, are all pupils of Professor Hoffmann, following in their master's footsteps. They have appreciated his teaching too well to neglect utility in what they produce. The right balance between art and utility is a prominent feature in the modern Austrian school. All the students at the Kunstgewerbe-Schule have drunk deep of this learning. Each element must have its due place and harmonise with its surroundings, and all conflicting elements must be avoided. There must be a surety in the building up of the whole. Otto Prutscher is rich in ideas and possesses a lively phantasy and a fine sense of harmony in line and colour. His strength lies in the interior decoration of the house and what pertains to it. Zülow has been successful in decorative furniture of another genre, namely, the adapting of the traditional designs of the peasants to modern art.

Many women, too, are to the fore in the applied arts. Before the modern movement they were chiefly interested in the old methods of coloured embroidery in silks, of flowers and other designs. The workmanship was always good, for the Austrian women excel in needlework of all kinds. Now they are taught on nature's system, and at the Imperial Kunstgewerbe-Schule they learn all branches of applied art, and by turning their thoughts to the simplest articles of every-day life are opening up a new field in art. The women students can turn their hand to most things, as can the men. Furniture building and architecture do not come within their scope, but all household properties do, and just in these they meet with success. The Austrian lady's linen closet is to her what the china closet is 
to the Englishwoman. Here art has a place, and the work is especially suitable for women. The bed linen is a source of joy to all, not for its elaborateness but for its simplicity. Fräulein Marietta Peyfuss has designed some fine pillow-cases and "Kappendecken" - these correspond to the upper sheet in England and button over on to the quilt, the corners being mitred. Fräulein Peyfuss's table-cloths are original, and at the same time works of art. Fräulein Uchatius, Fräulein Hollman, Fräulein Exner, Fräulein Sodoma, Frau Taussig-Roth, are each doing their share in the promotion of decorative art. Fräulein Trethahn has designed some tea and coffee services and toilette sets which, though original, bear traces of the new school. Fräulein Wachsmann has designed wallpapers, linings for books, carpets and other textiles which show tine feeling and sound technique. Fräulein Sika has turned her talents to electric pendants and table decorations, including tea and coffee services; Baroness Falke to ceramics and electric standard lamps. Some of these men and women artists have formed a small society called "Kunst im Hause."

Fräulein von Starck is teacher of the art of enamelling at the Kunstgewerbe-Schule, which in itself is the best testimony of her capabilities. Bruno Emmel, B. Löffler and E. Powolny are devoting themselves to ceramics. In the course of time each artist may perhaps devote attention solely to some particular branch. Being many sided, as is but natural considering who are their teachers, they are trying their strength in every direction, and each is doing his share in raising the standard of Austrian decorative art.

A new generation is also arising at the Imperial School of Embroidery, where, under the teaching of B. Löfller, Fräulein Betty Stooss, Fräulein Guttmann, and others are searching new methods for carrying out their own designs in embroidery, and what is generally called fancy work. The Kunst-Schule für Frauen und Mädchen is also doing valuable work; two of Professor Böhm's students, Frau Sakuka-Harlinger and Fräulein Podhajska, have done some good decorative work and are excellent in modern toys, which subject does not come within the scope of this work.

Many men are devoting themselves to special branches of the arts and crafts. Gustav Gurschner, whose bronzes are known far and wide, is also a sculptor; Ernst Stöhr is a painter and mural decorator; Maximilian Lenz is a painter, yet he has designed some beautiful electric lamps in beaten silver; Friedrich König is a painter and designer-this reads like the old signboards; Engelhart $\mathrm{D} \mathrm{x}$ 
is a painter, a sculptor and a craftsman; indeed, nothing is more astonishing than the versatility of these Austrian artists.

In Austria there is little opportunity for the artist as far as fireplaces are concerned. This is a land of stoves, which are much better adapted to warming the rooms and equally distributing the heat than open fires. Therefore the artist must devote his talents to designing such things as tiles and door plates, for which, however, there is little demand, the question of cost being important. It must be remembered that here flats are the rule; they are built for the purpose of letting as cheaply as possible, and all unnecessary outlay must be carefully avoided. In some few villas there are open fireplaces, but they are not in favour because they do not give out sufficient heat to warm all parts of the room, which is a very important consideration in this cold climate. Therefore for the artist there only remains the gas stove, which is generally welcomed. Here all the artists mentioned have employed their thoughts and talents, and some very fine designs have been made by the leading men, many of them with fine mantelpieces, which were unknown till within the last few years. Electric lighting is coming more and more into vogue. This gives a splendid opportunity to the artist, and here again the leading men, including Professor Hoffmann, Professor Moser, Urban, Bauer, Krauss, Prutscher, Ofner, have done some excellent work.

With wall-papers few artists have concerned themselves, for the reason that they are not in demand. A visit to the leading firms taught me that most are imported from England and Germany, where the cost of manufacturing is far less than here. Neither do the leading architects use paper for their wall surfaces. Professor Hoffmann uses either rough cement or stuccoed mortar, or stains the walls to harmonise with the furniture, and heads them with a frieze, the design, of course, conforming to the furniture. Many architects use silk, or a special kind of textile which looks like buttercloth, and has the advantage of being washable and cheap. This is sometimes used in natural colour, and sometimes has a special design made by the artist. Wood, too, plays an important part in wall surfaces, especially in dining-rooms; this generally reaches about one-third of the height, the upper part being stained and headed with a frieze. The Prag-Rudniker Korbwaren Fabrication have even found a use for shavings for wall surfaces which were designed by W. Schmidt. They form a good background for wicker furniture.

The curtains are simple. Some very fine results have been achieved by the application of a simple geometrical design on white or cream lustre specially manufactured for this purpose. This is very effective 
and at the same time very practical. Chintz and cottons of the simplest designs, spotted or checked, which have the advantage of being cheap, form artistic hangings, and are used by many leading architects. The chief thing is artistic value combined with utility; hangings may be very expensive and yet, from an artistic point of view, valueless. White batiste, of a special design, is also favoured, especially by Adolf Loos.

Stained-glass windows are rarely seen in the residential flats or houses. Professor Moser, Professor Mehoffer, Professor Roller and other artists have designed some very fine windows for the "Secession," for public buildings and for churches. They have also designed some beautiful mosaics. Few, except Professor Moser, have turned their thoughts to glass. He excels in this, for he understands the nature of the material. Some of his pupils follow in his footsteps, and with fairly good results. In silver-plate much could be done were the public educated up to a due appreciation of art. As it is, the so-called "Secession," which is nothing but a base imitation of the real thing, finds buyers, and often at a cost equal to the genuine. Matters are mending; everywhere there is a desire to understand art ; there is movement, and that means much; anything is better than the dead monotony of a few years ago. The manufacturers need educating, as do the public, for Austria does not in this respect differ from other countries. 
D 1 B. LÖFFLER AND M. POWOLNY

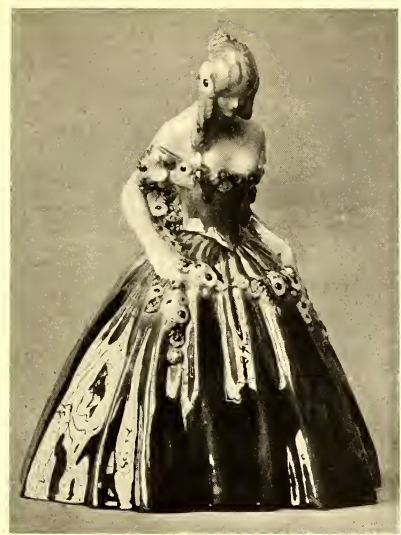

CERAMIC FIGURE

\section{2 BRUNO EMMEL}

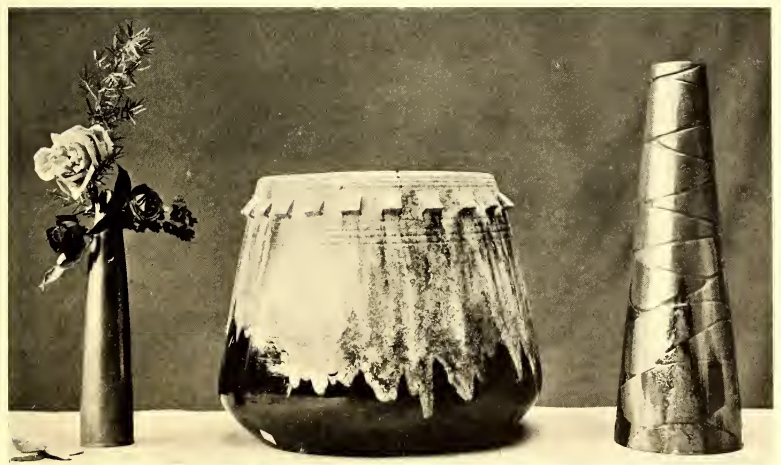

POTTERY EXECUTED BY GEBRÜDER REDLICH, GOEDING, MORAVIA 


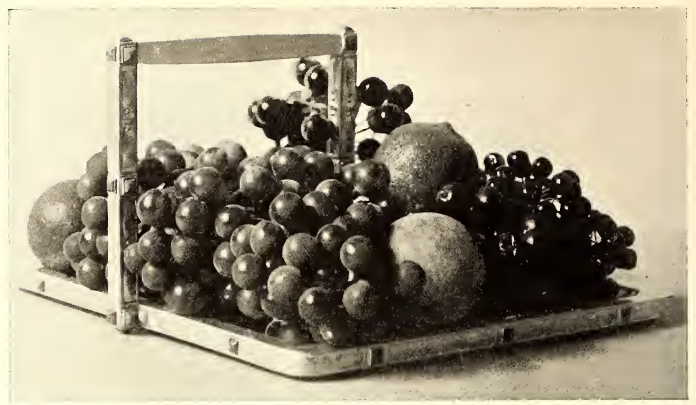

FRUIT STAND IN SILVER SET WITH STONES EXECUTED BY THE WIENER WERKSTAETTE (BY PERMISSION OF HERR HOFRAT KOCH)

D 4 PROF. JOSEF HOFFMANN

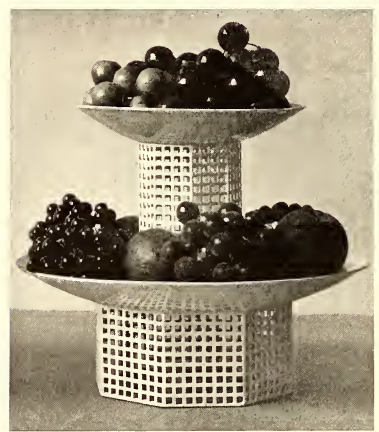

D 5 PROF. KOLOMAN MOSER

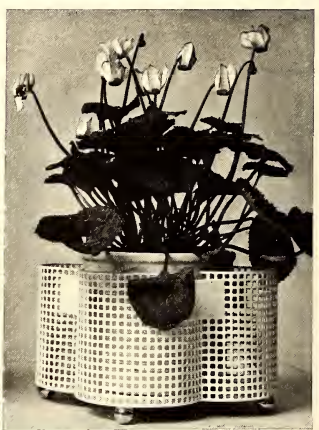

FRUIT STAND AND FLOWER POT IN GALVANISED IRON ENAMELLED WHITE EXECUTED BY THE WIENER WERKSTAETTE (BY PERMISSION OF HERR HOFRAT KOCH) 


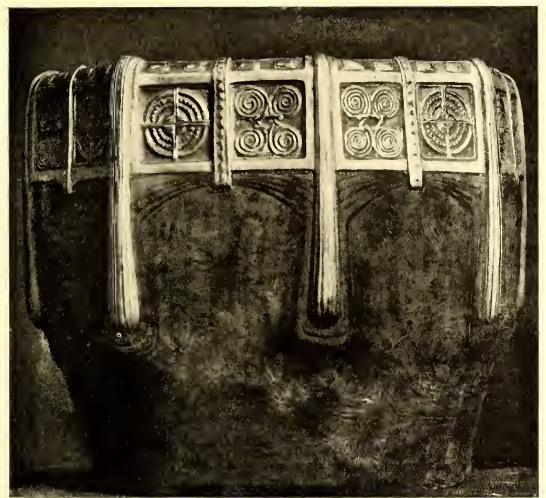

D 7 BRUNO EMMEL

PALM POT IN BRONZE

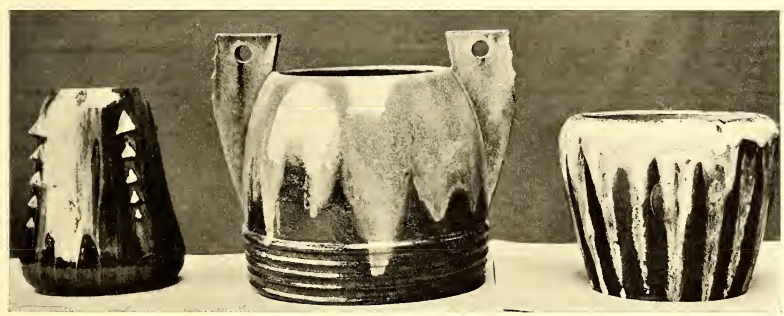

POTTERY EXECUTED BY GEBRÜDER REDLICH, GOEDING, MORAVIA 
D 8 \& 9 J. SIKA

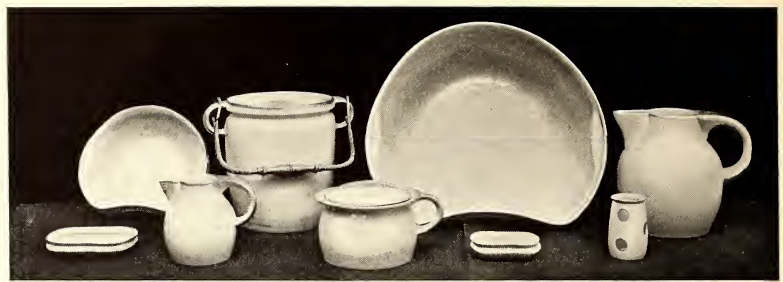

TOILET WARE EXECUTED BY J. BÖCH VIENNA

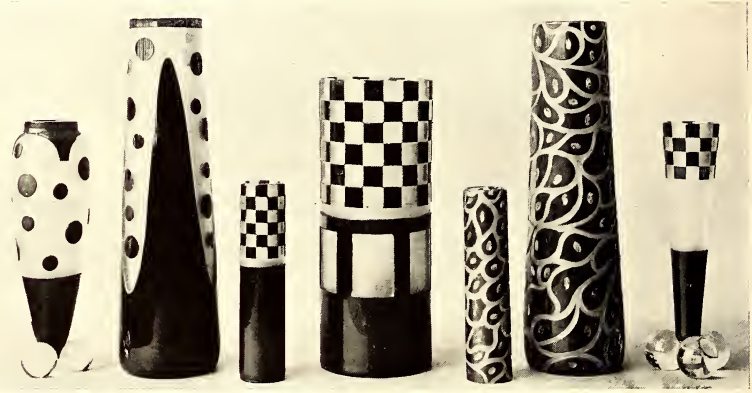

RED AND WHITE GLASS VASES EXECUTED BY BAKALOWITS \& SONS VIENNA 

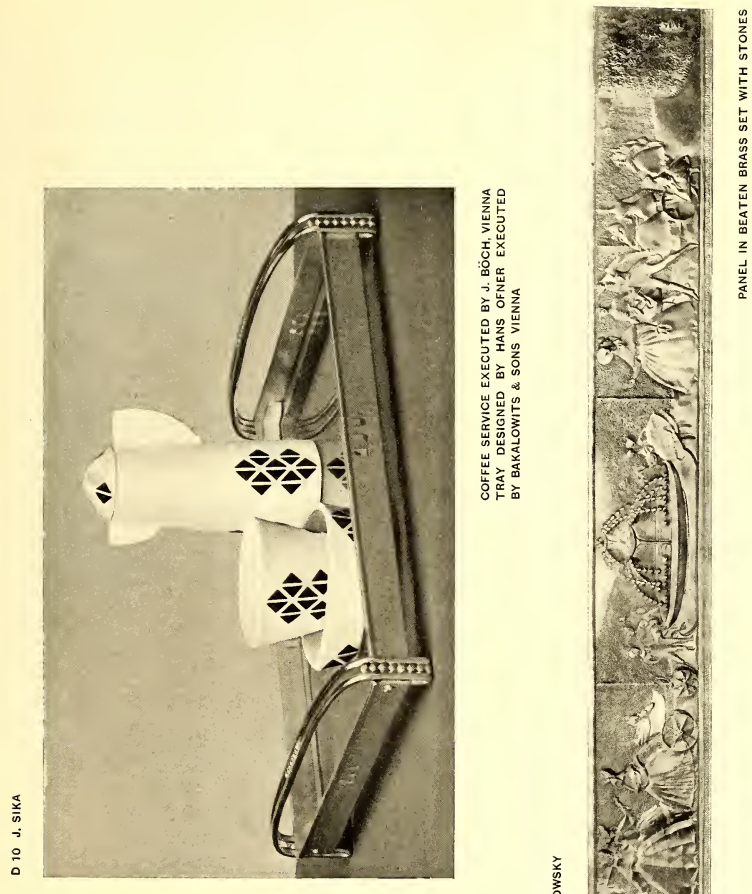

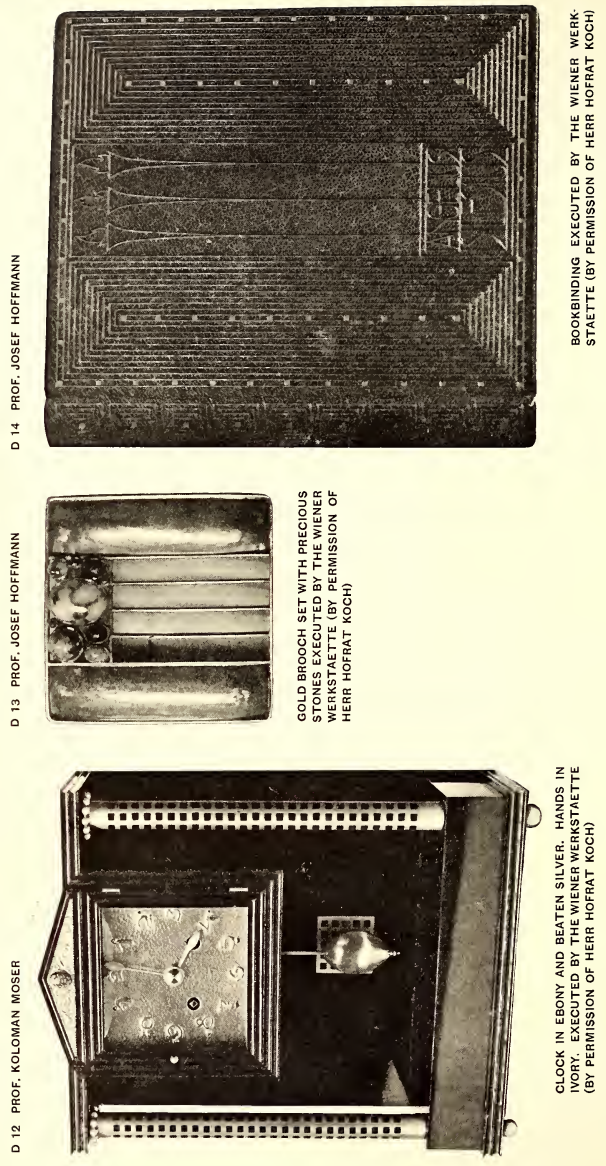
D 15 OTTO PRUTSCHER
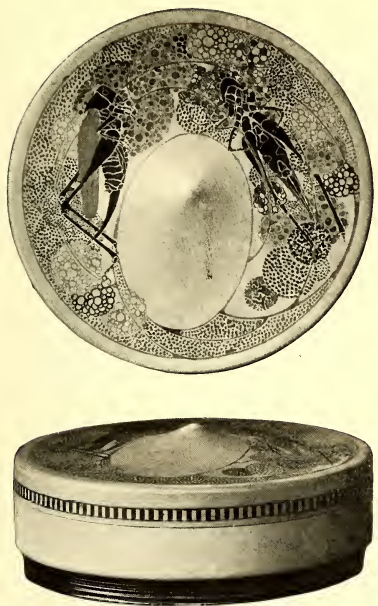

HAND-PAINTED BON BONNIËRE

D 16 PROF. KOLOMAN MOSER

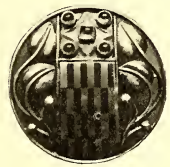

SILVER BROOCH SET WITH STONES EXECUTED BY THE WIENER WERKSTAETTE (BY PERMISSION OF HERR HOFRAT KOCH
D 17 \& 18 PROF, JOSEF HOFFMANN
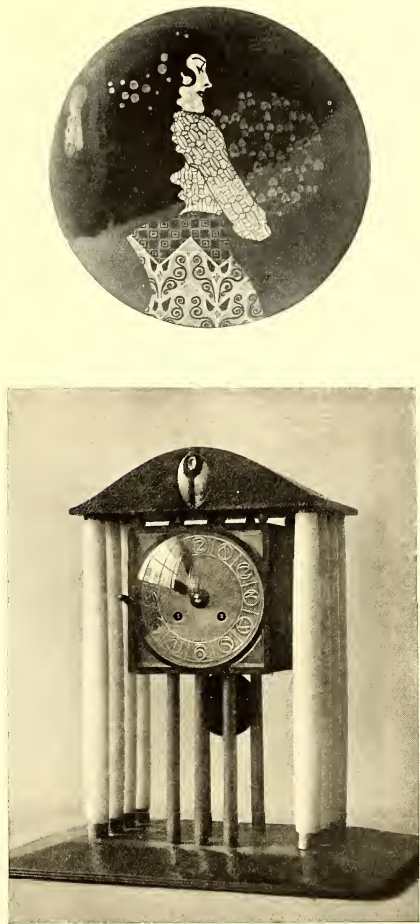

JEWEL BOX IN PAINTED MAPLE AND CLOCK IN HAMMERED METAL AND MARBLE EXE. CUTED BY THE WIENER WERKSTAETTE (BY PERMISSION OF HERR HOFRAT KOCH) 


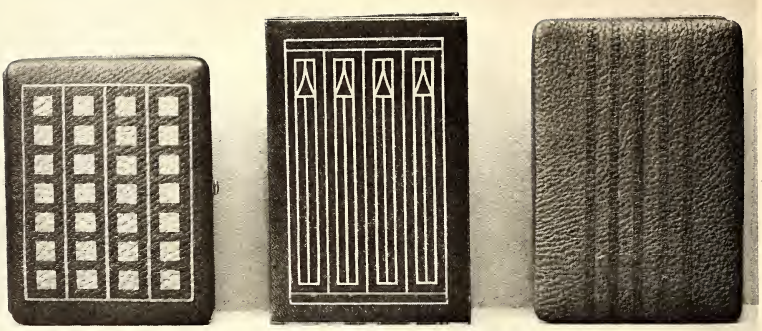

CIGARETTE AND CARD CASES EXE. CUTED BY R, MELZER JUN., VIENNA

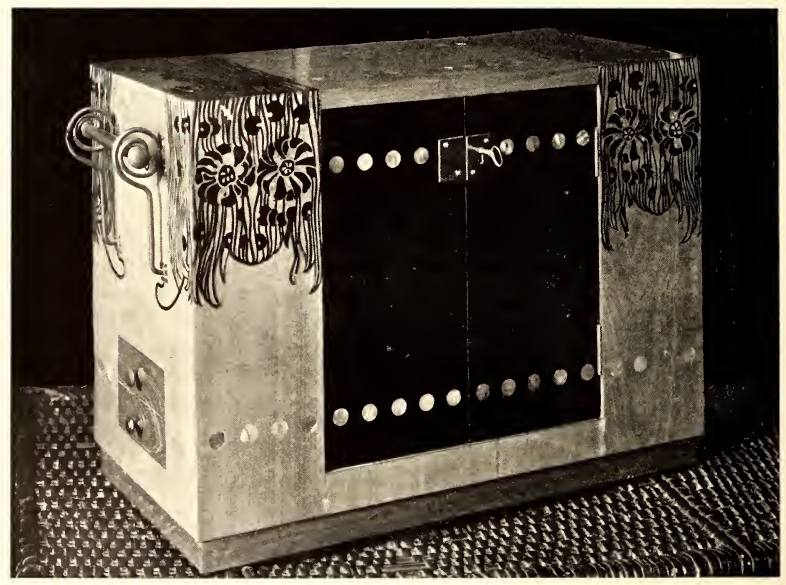

JEWEL CASE IN ROSEWOOD INLAID WITH MOTHER-OF-PEARL AND VARIOUS WOODS EXECUTED BY JOHANN BAUWIC, VIENNA 
D 21 PROF. JOSEF HOFFMANN

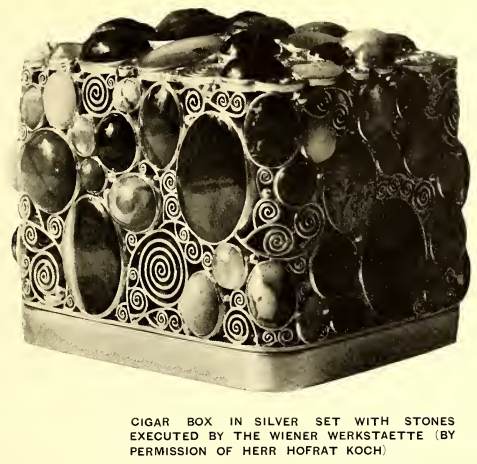

D 22 PROF KOLOMAN MOSER

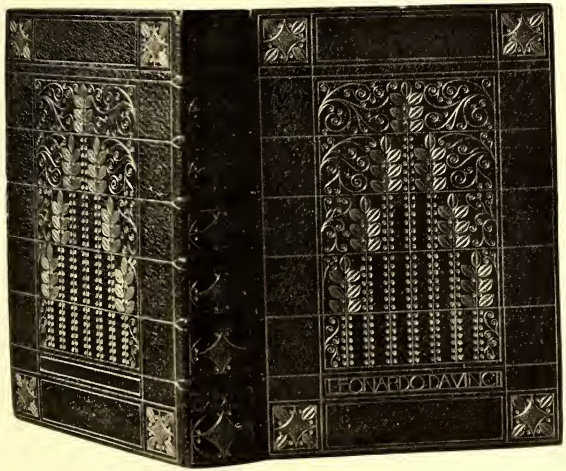

BOOKBINDING IN MOROCCO INLAID EXE. CUTED BY THE WIENER WERKSTAETTE (BY PERMISSION OF HERR HOFRAT KOCH) 

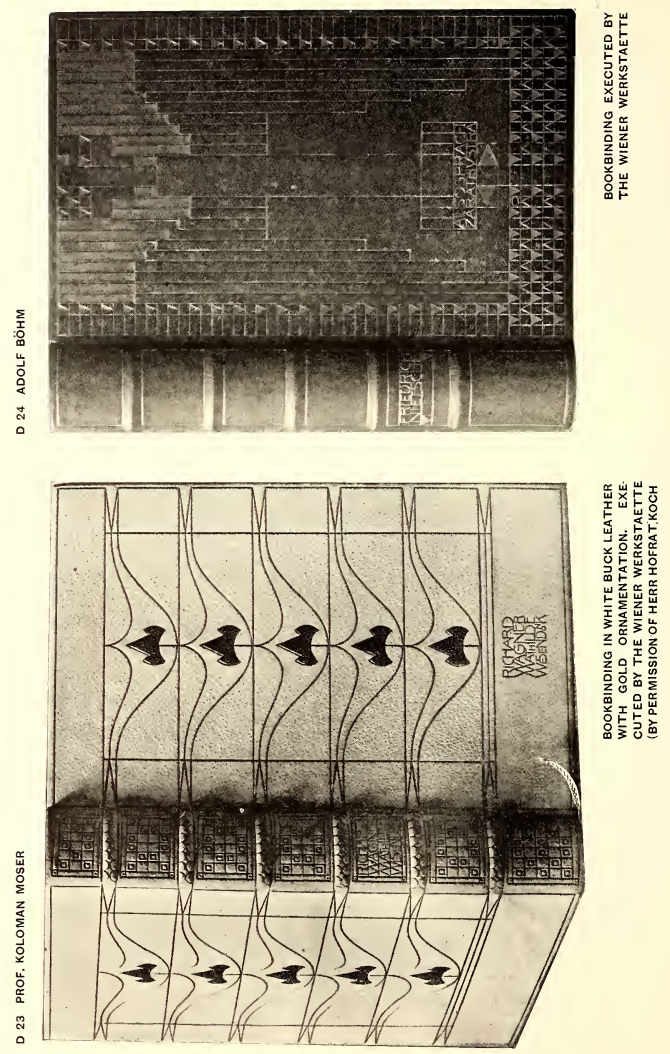


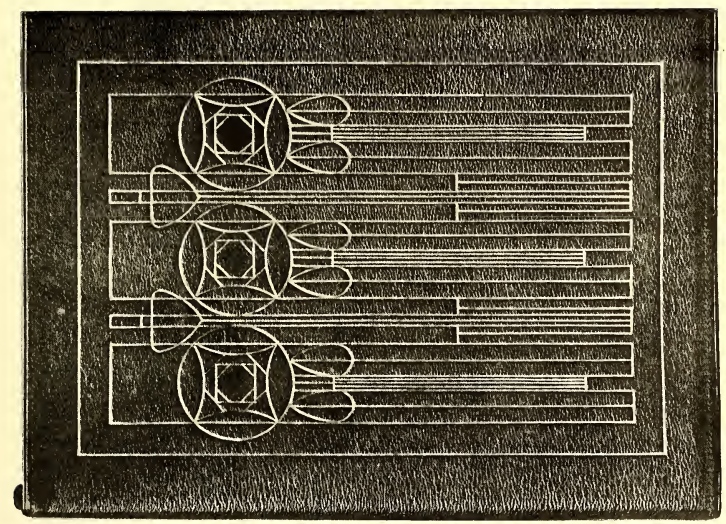

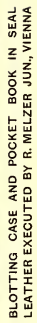

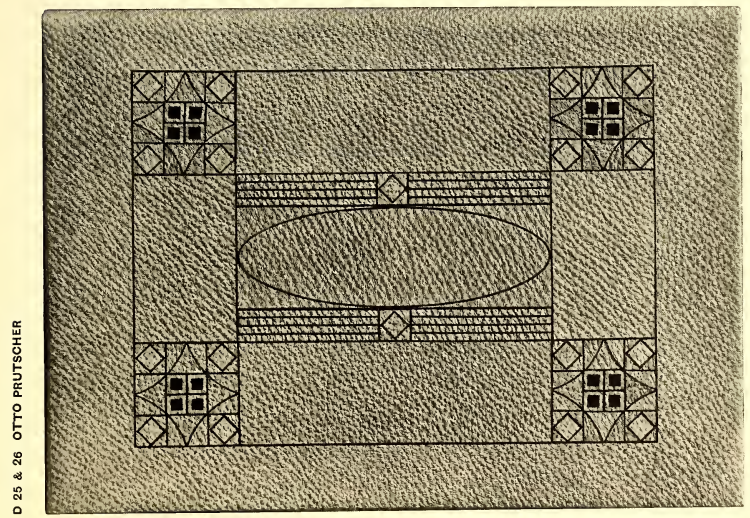


D 27 E. SUMETSBERGER

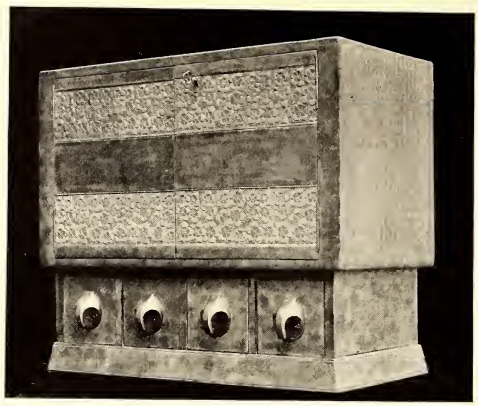

LEATHER JEWEL CASE EXE

CUTED BY B BUCHWALD VIENNA

D 28 V. SCHOENTHONER

D 29 OTTO PRUTSCHER
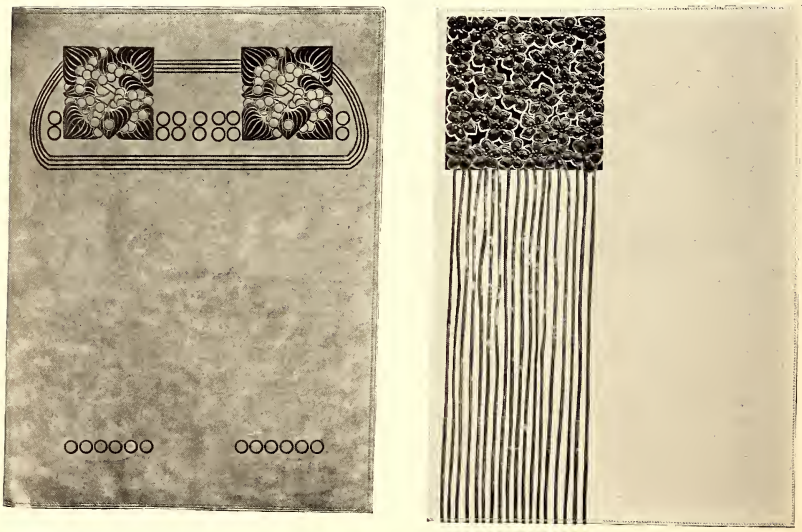

LEATHER BLOTTING CASES EXE

CUTED BY B. BUCHWALD VIENNA 
D 30 PROF. HEINRICH LEFLER \& JOSEF URBAN.

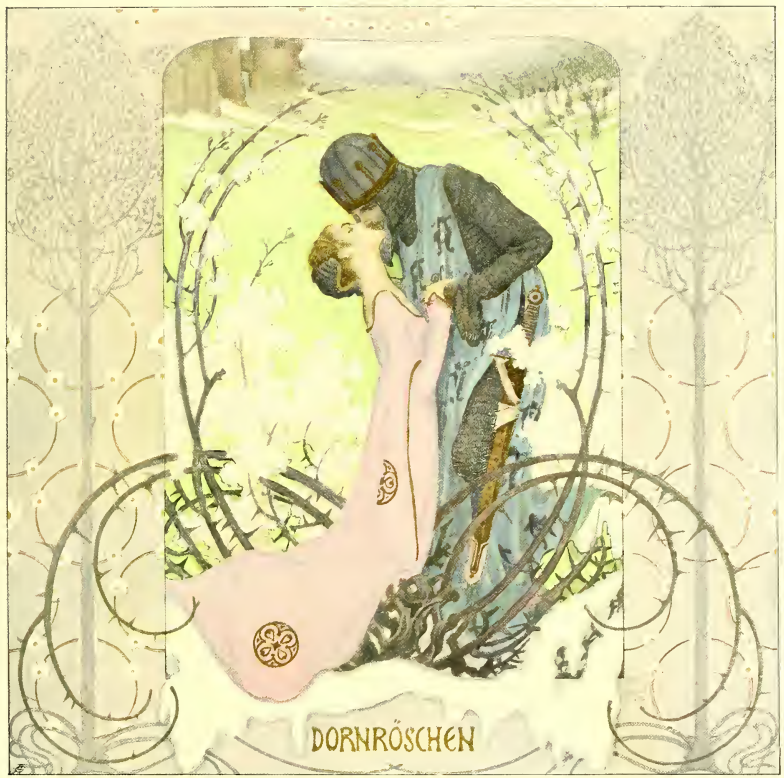





$$
s_{i n}
$$




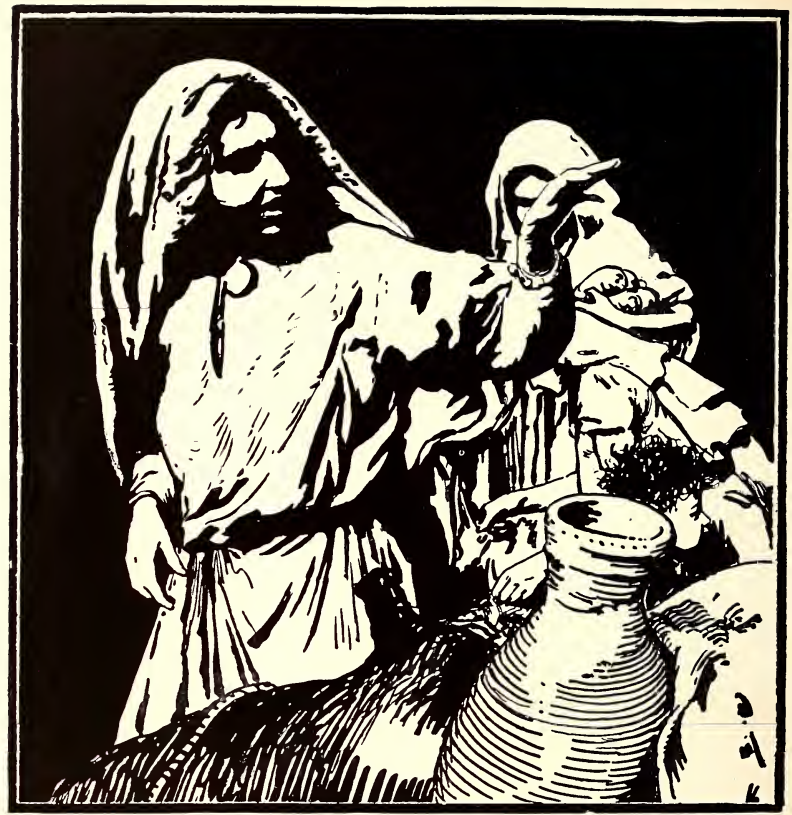


33 FERD, ANDRI

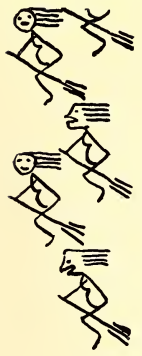

D 34 KARL FAHRINGER

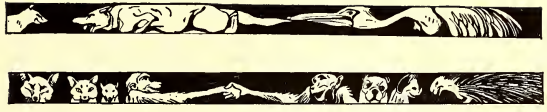

a

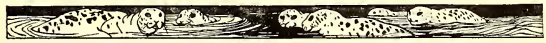

20

D 35 IGN. TASCHNER
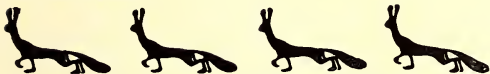

D 36 IGN. TASCHNER
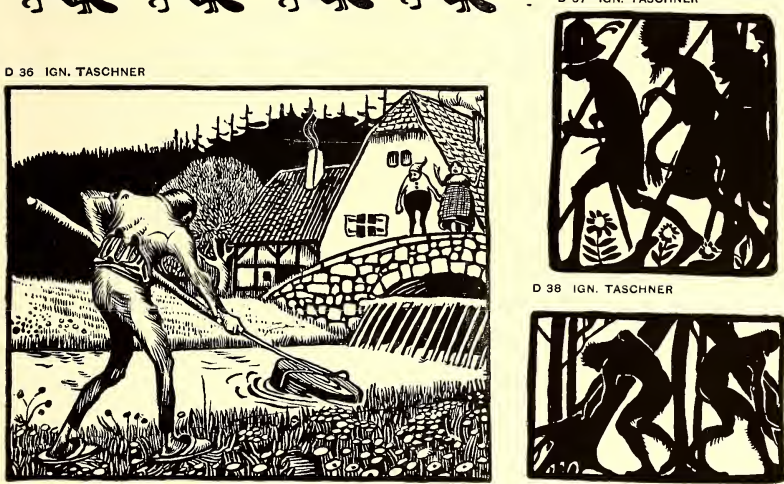

D 38 IGN. TASCHNER

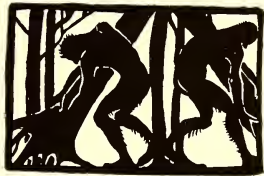



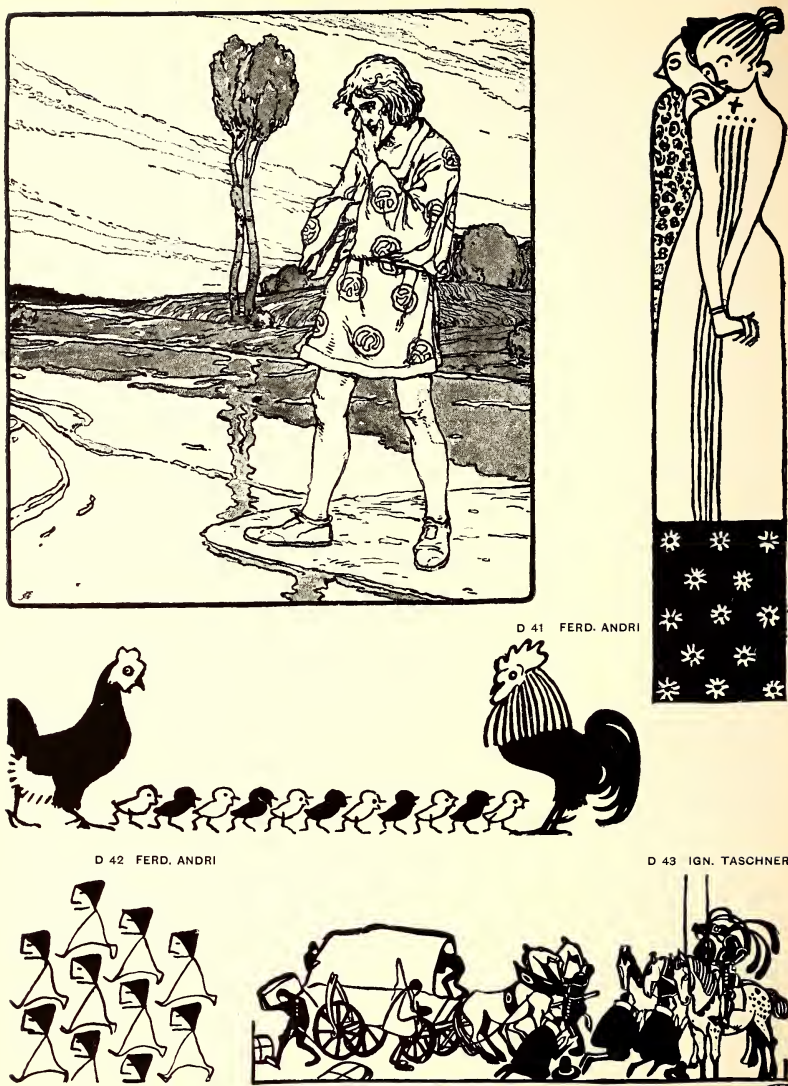

浆 光谈 * 


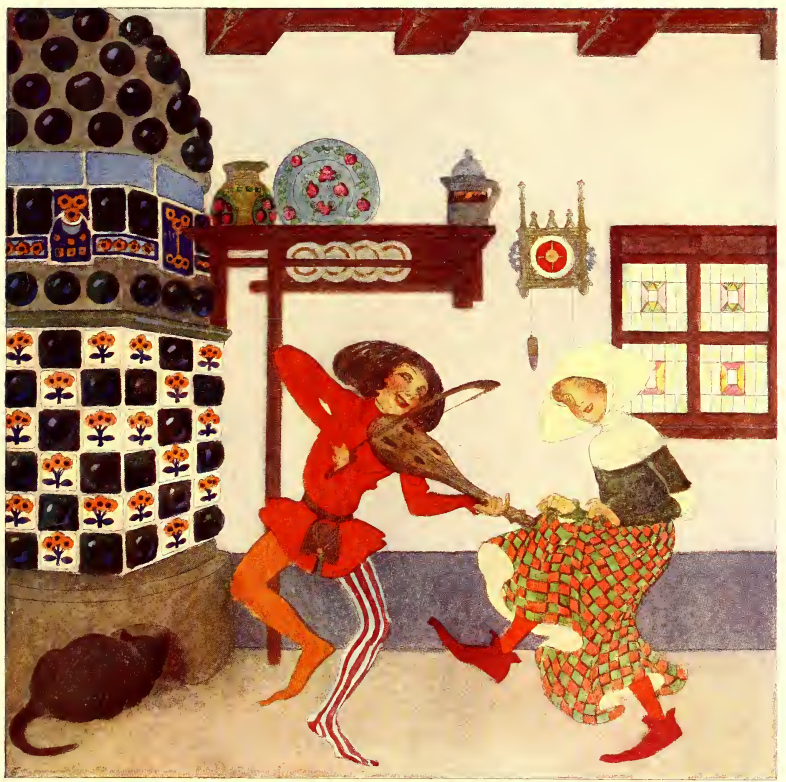


- 


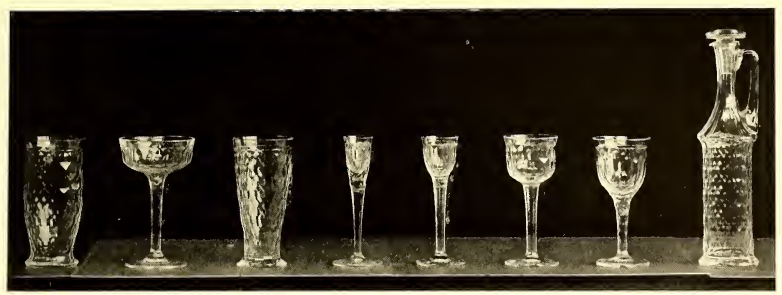

GLASSWARE EXECUTED BY BAKA

D 46 OTTO PRUTSCHER

LOWITS \& SONS, VIENNA

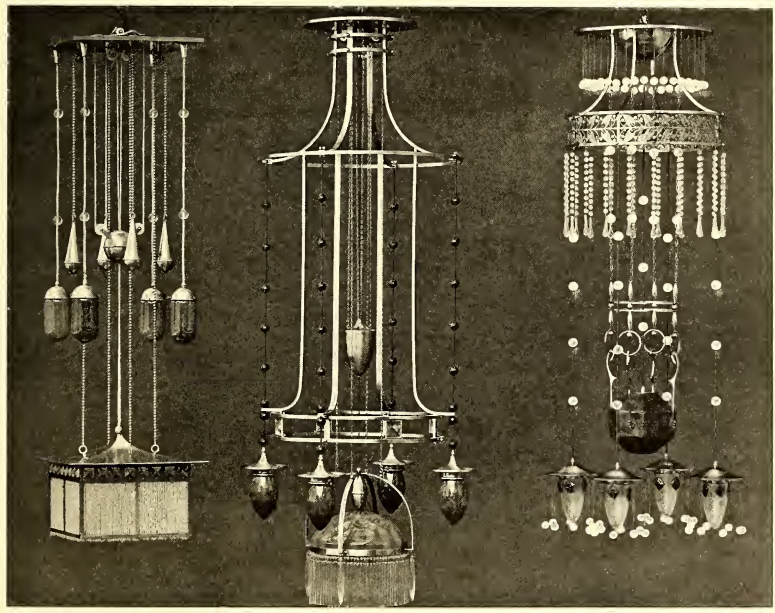

ELECTRIC LIGHT PENDANTS EXECUTED BY BAKALOWITS \& SONS VIENNA 


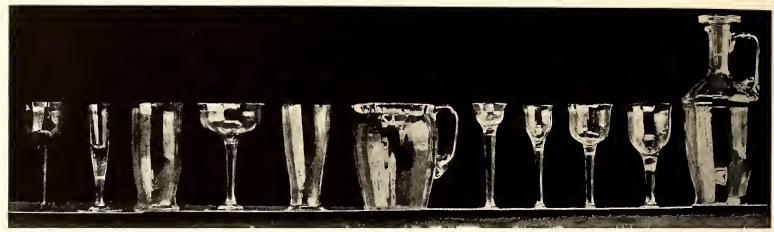

GLASSWARE EXECUTED BY BAKA LOWITS \& SONS VIENNA

D 48 EMIL HOPPE

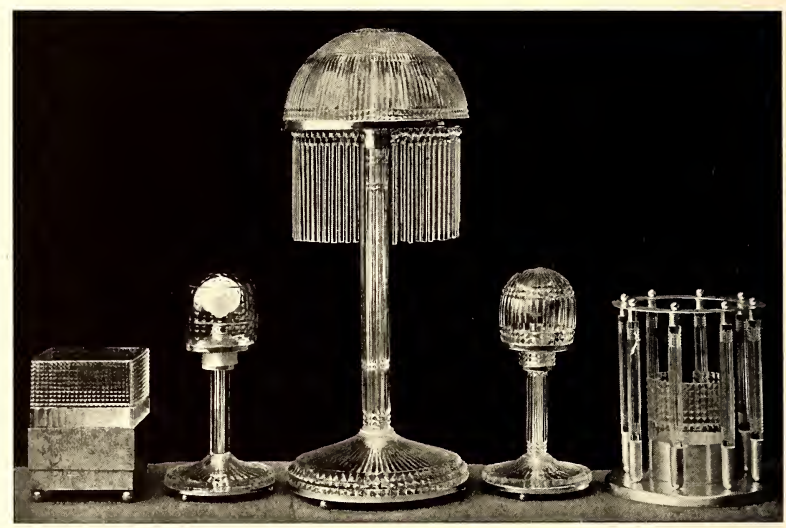

TABLE LAMPS AND FLOWER STANDS EXE

CUTED BY BAKALOWITS \& SONS, VIENNA 


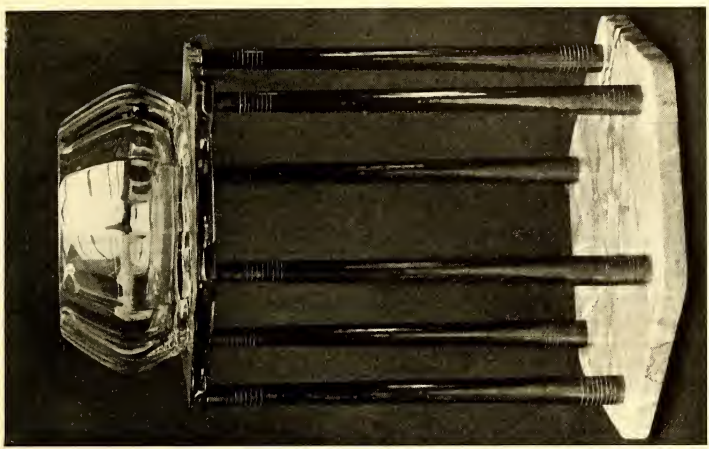

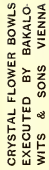

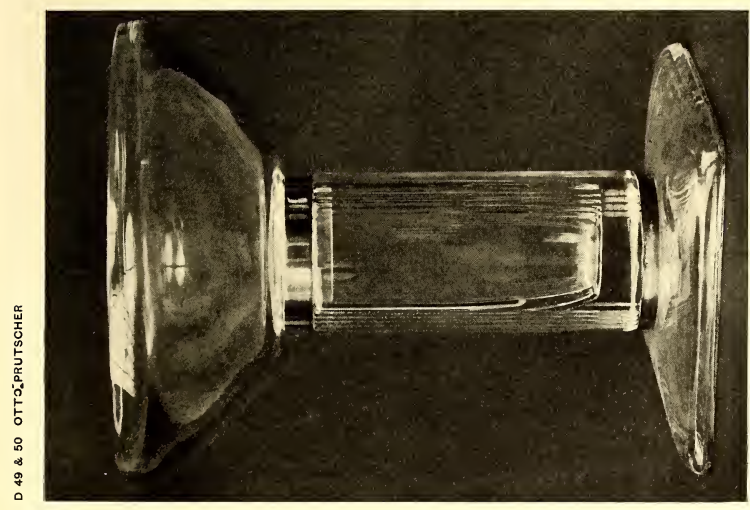




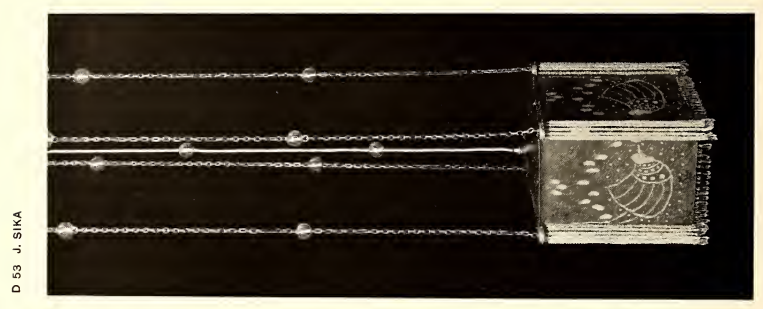

这专商孚

占包离

ô

wू

눙

造。

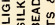

का

온 옹

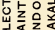

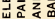

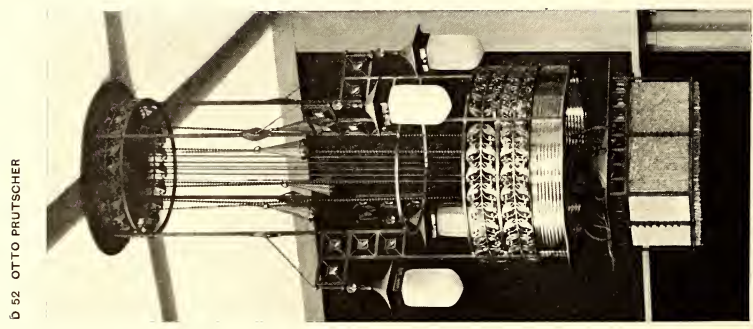

그ํ 这

攴品突

虽娣

㟧吠

I o $\infty$

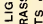

0

준일

岃

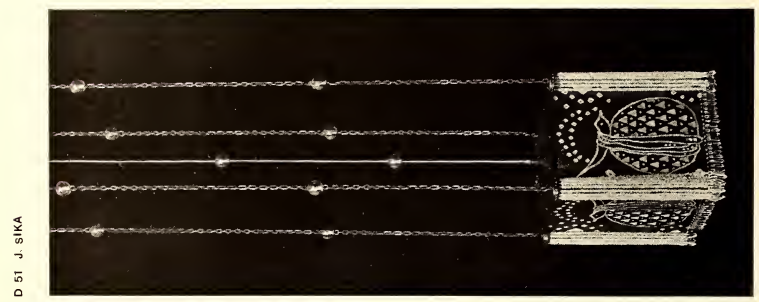

㟔支㐫通

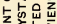

和路>

势

웅요

1

的峞

을

낭영

氙:

过造这希 
D 54 HANS OFNER

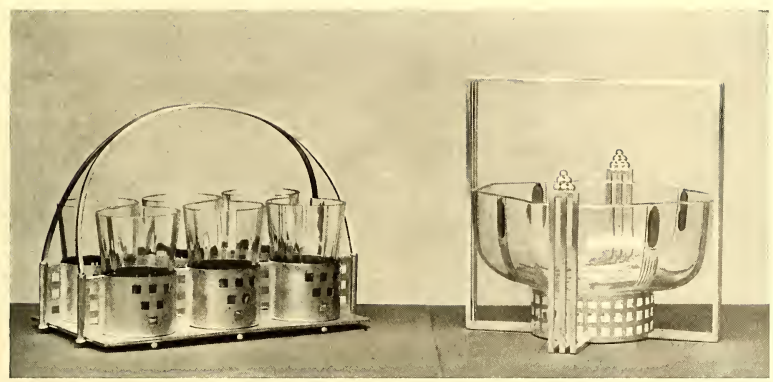

D 55 \& 56 BARONESS FALKE
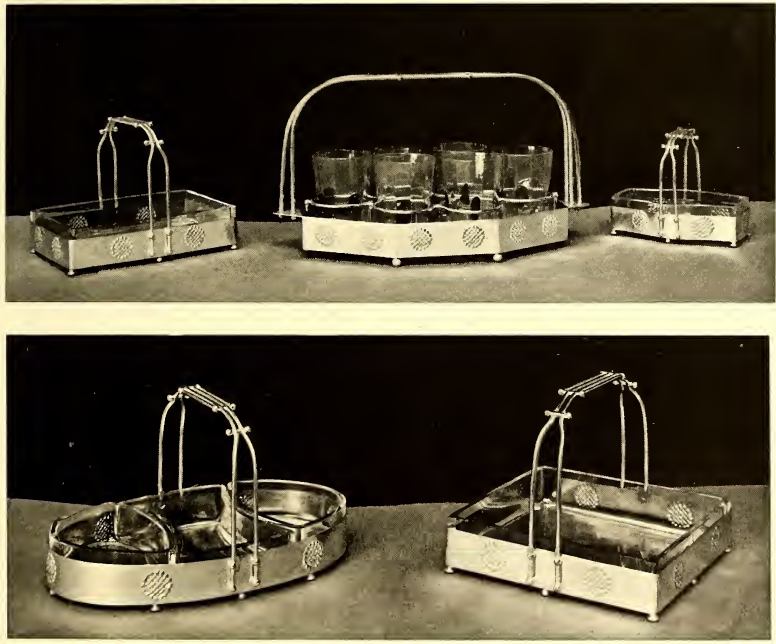

TABLEWARE EXECUTED BY BAKALOWITZ \& SONS, VIENNA 
D $57-61$, AROF. JOSEF HOFFMANN
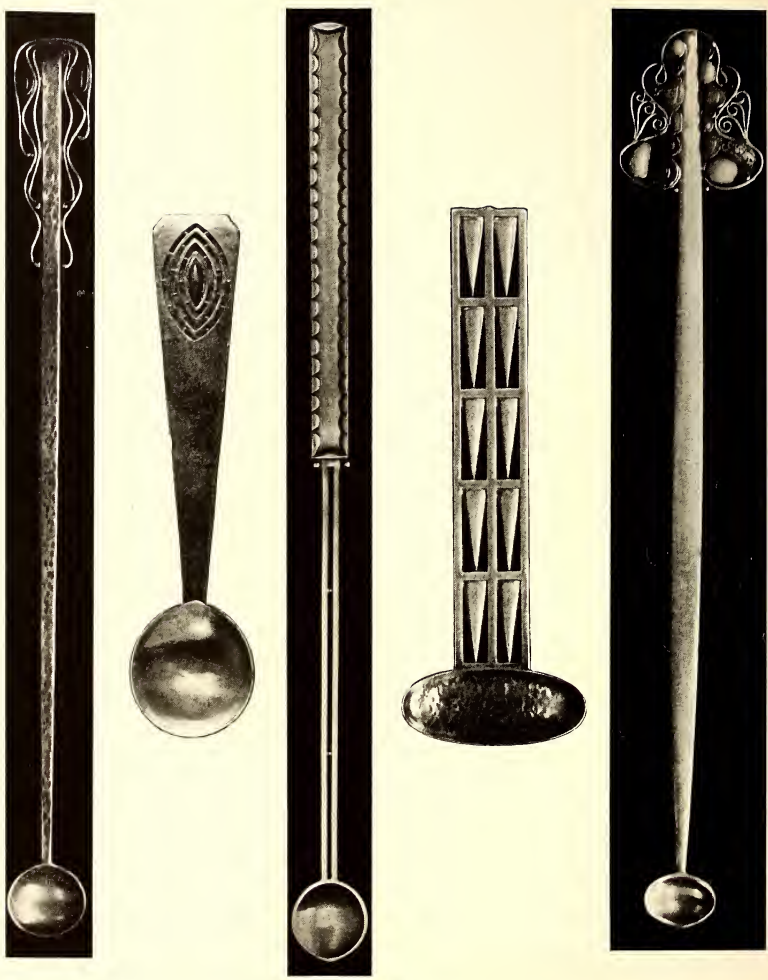

SILVER SPOONS EXECUTED BY THE WIENER WERKSTAETTE (BY PERMISSION OF HERR HOFRAT KOCH)

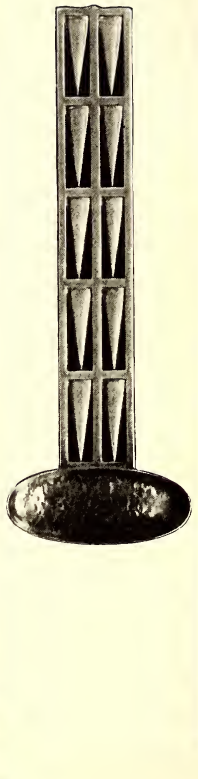



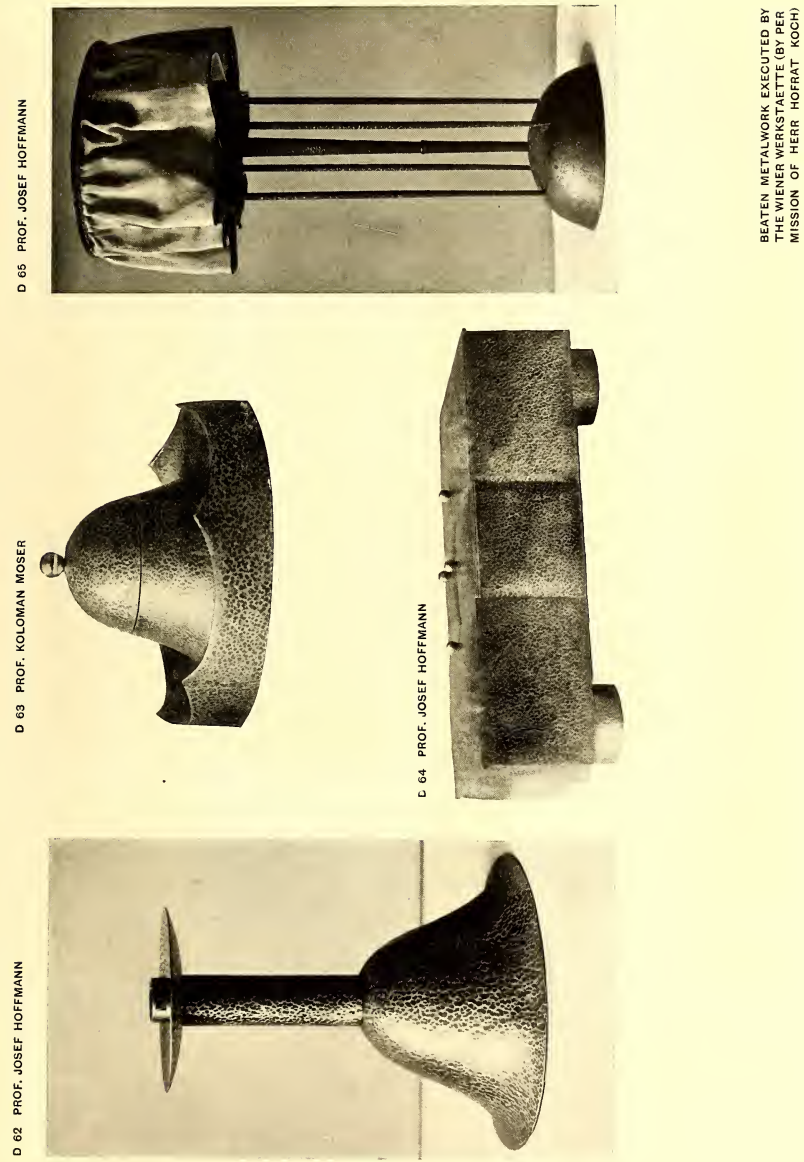
D 66 ELENA LUKSCH-MAKOWSKY
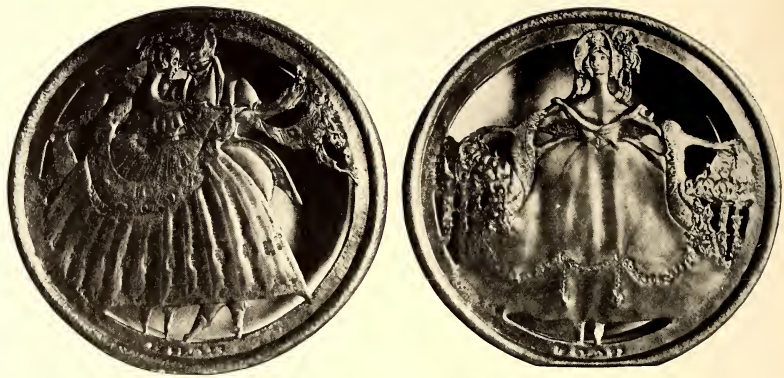

COVERS FOR VENTILATORS

IN HAND BEATEN BRASS

D 67 PROF. CZESCKA

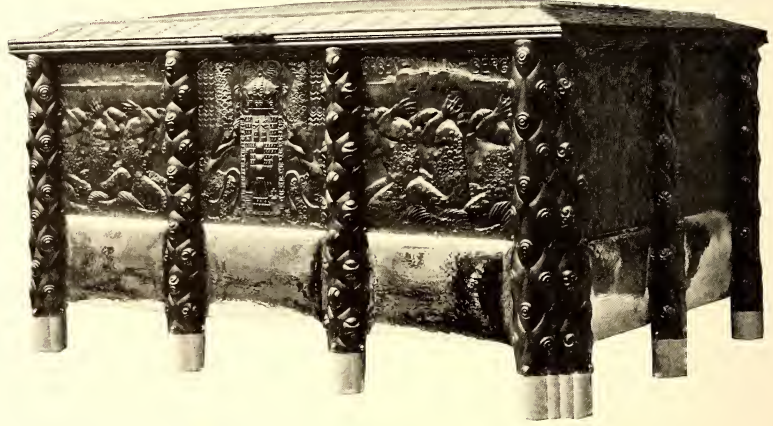

CASKET IN BEATEN SILVER PRESENTED TO HIIM.

FRANZ JOSEF I. BY MESSRS. SKODA \& $C O$

EXECUTED BY THE WIENER WERKSTAETTE

(BY PERMISSION OF HERR HOFRAT KOCH) 


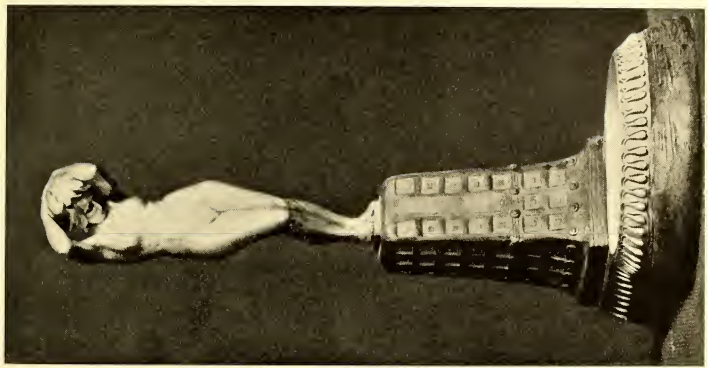

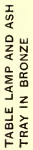

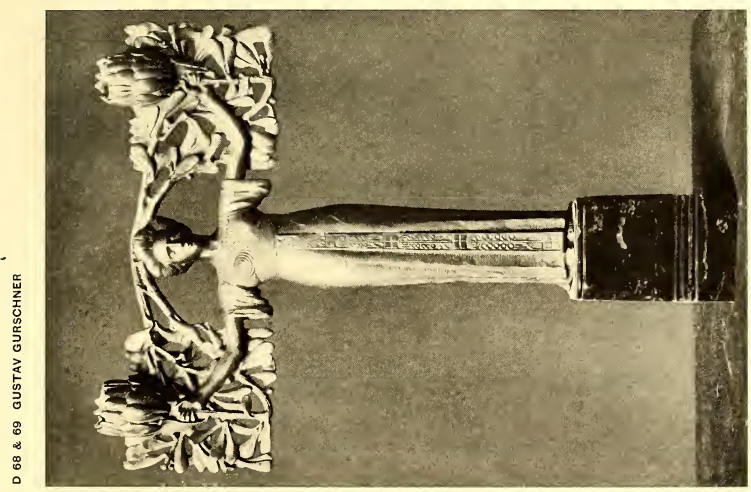




\section{70 MAXIMILIAN LENZ}

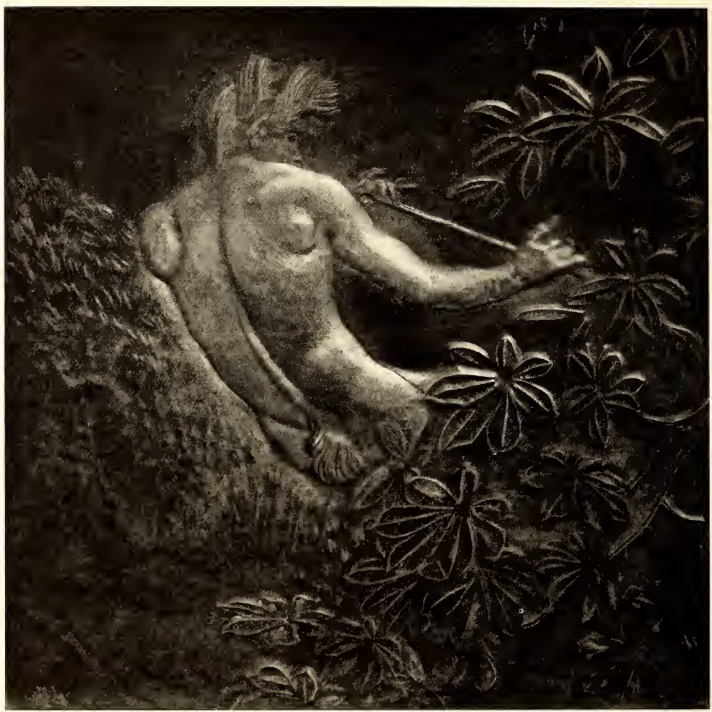




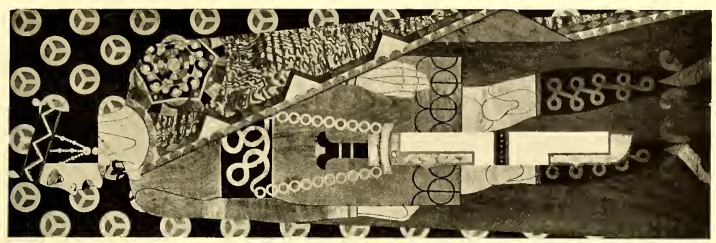

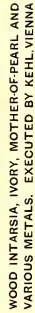
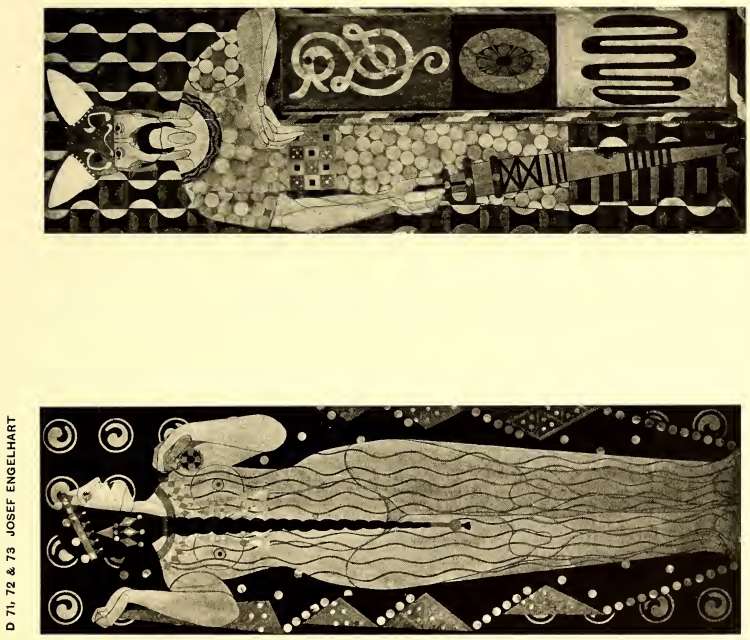

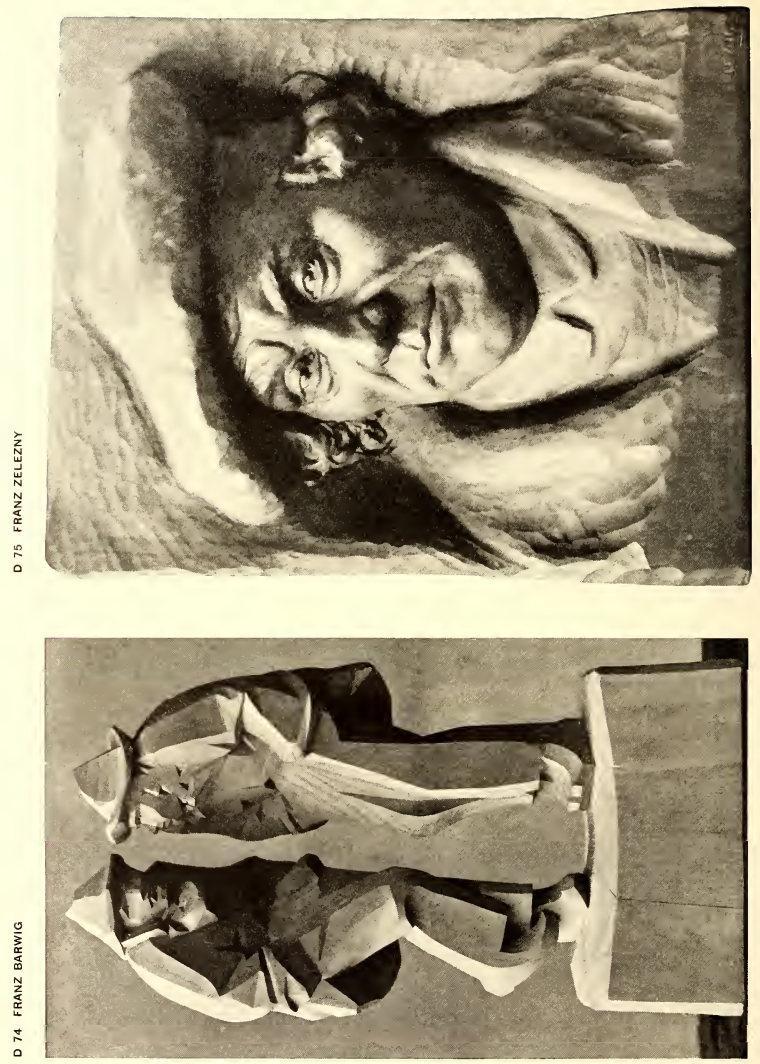


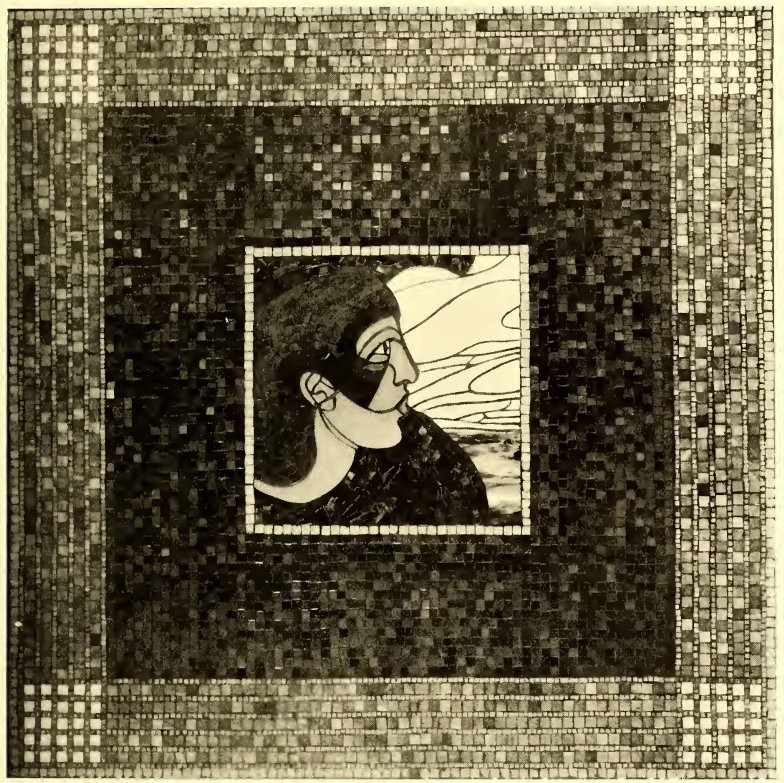




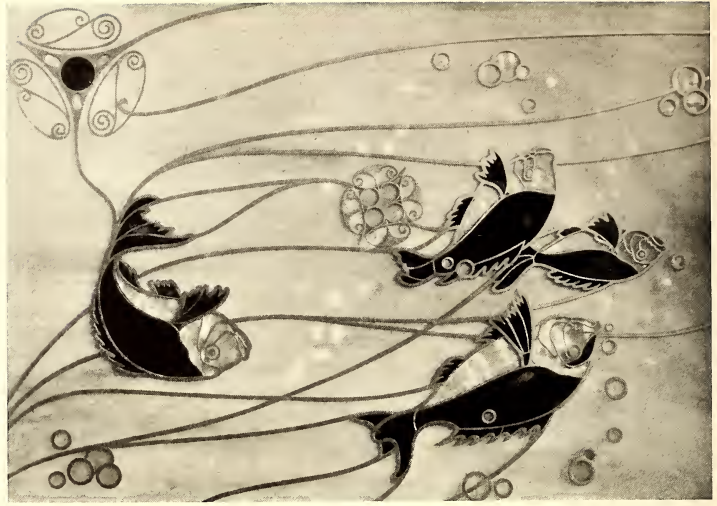

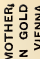

题

แू.

记

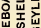

䟖

क出

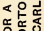

안잉

乌ㅇํ

z

는

的敌总

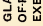

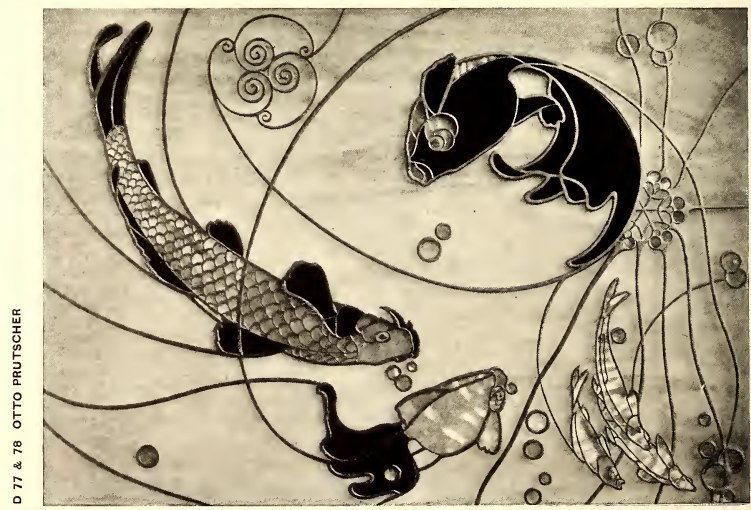



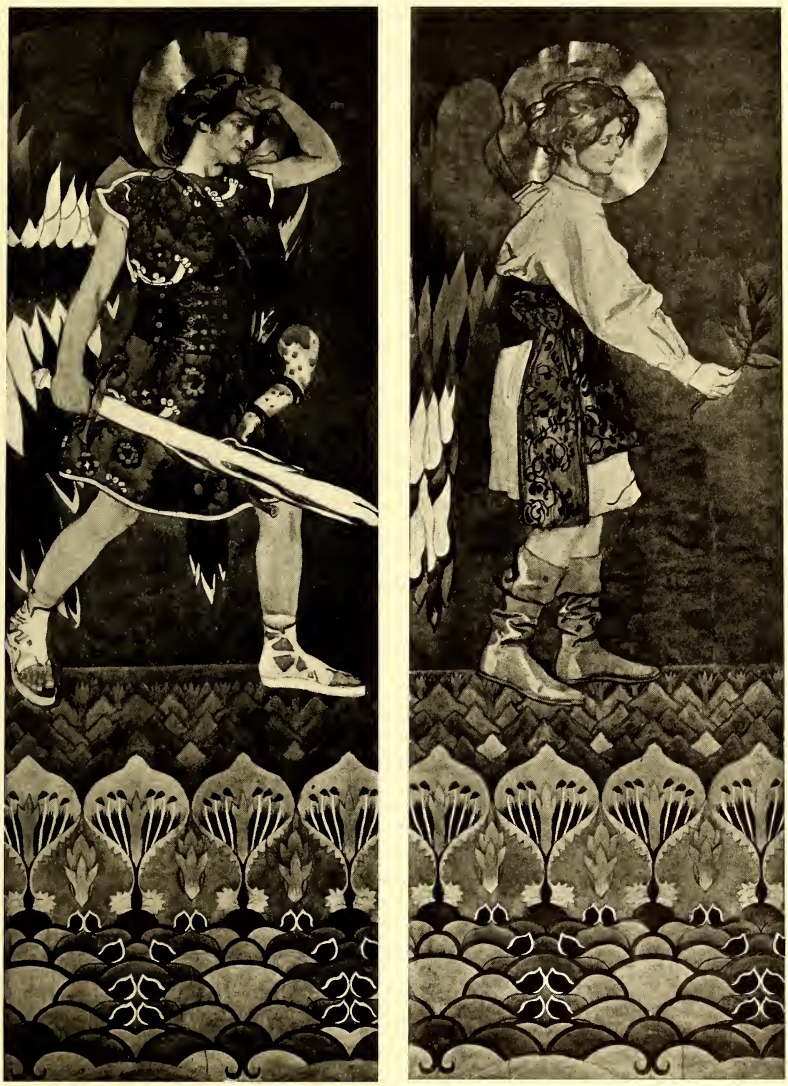

¿THE ARCHANGELS MICHAEL AND RAPHAEL MURAL DECORATION IN THE CHAPEL OF THE CATHEDRAL AT CRACOW 


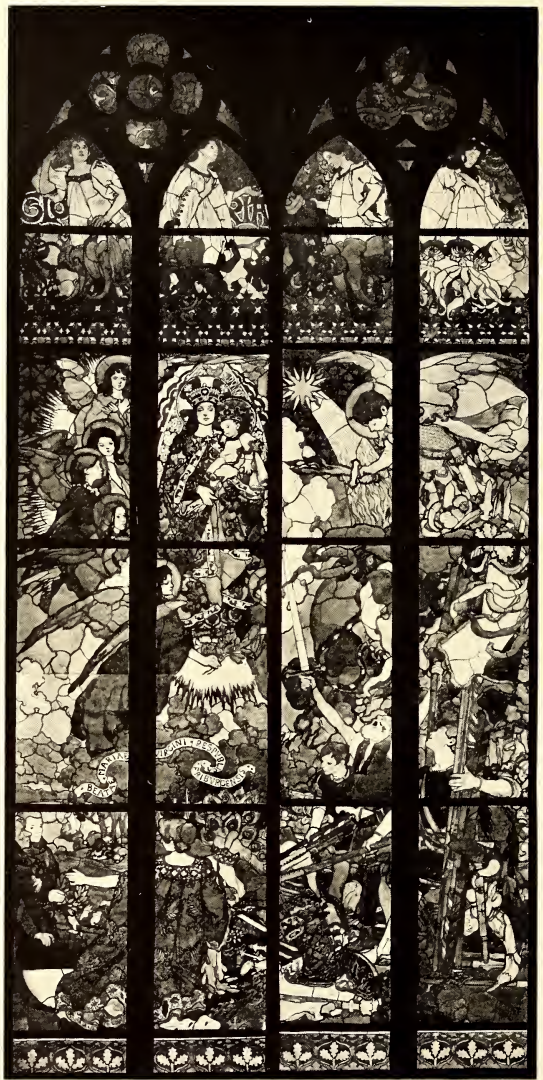

"NOTRE DAME DES VICTOIRES"

DESIGN FOR A WINDOW IN

THE CATHEDRAL' AT FRIBOURG

SWITZERLAND 


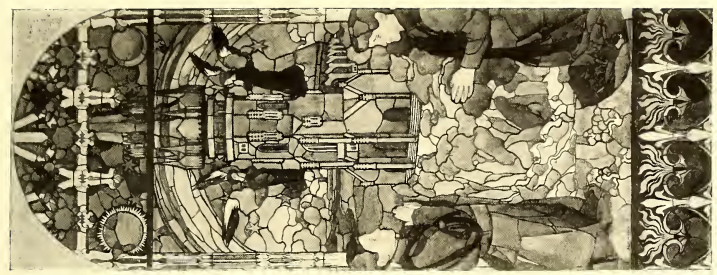

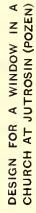
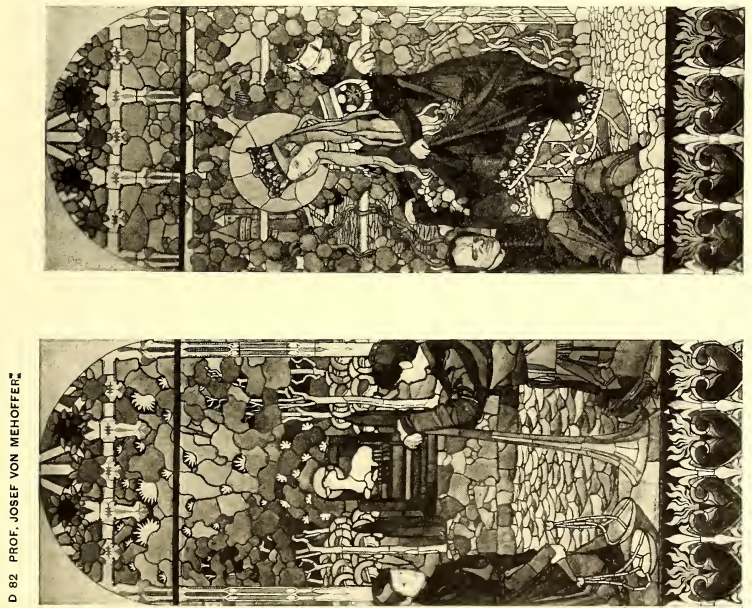


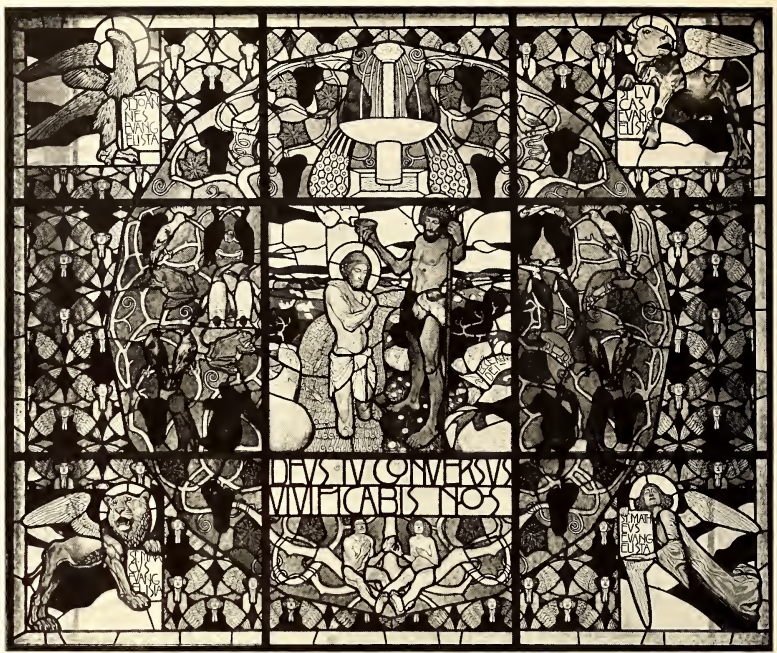




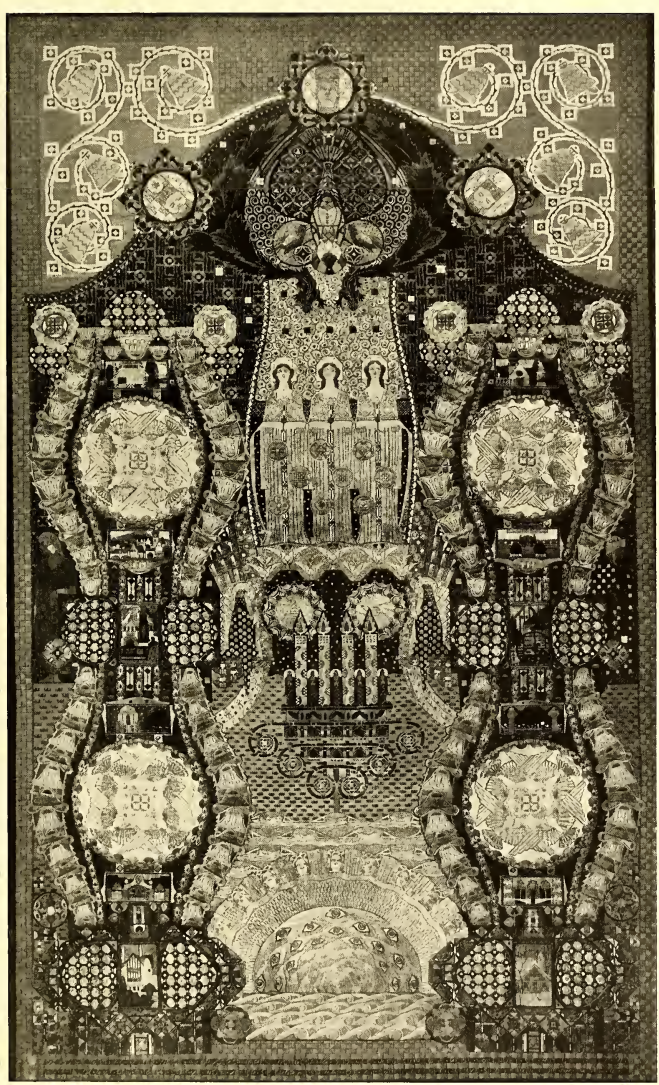

TAPESTRY IN THE MUSIC ROOM

OF THE GRAND DUKE OF HESSE 


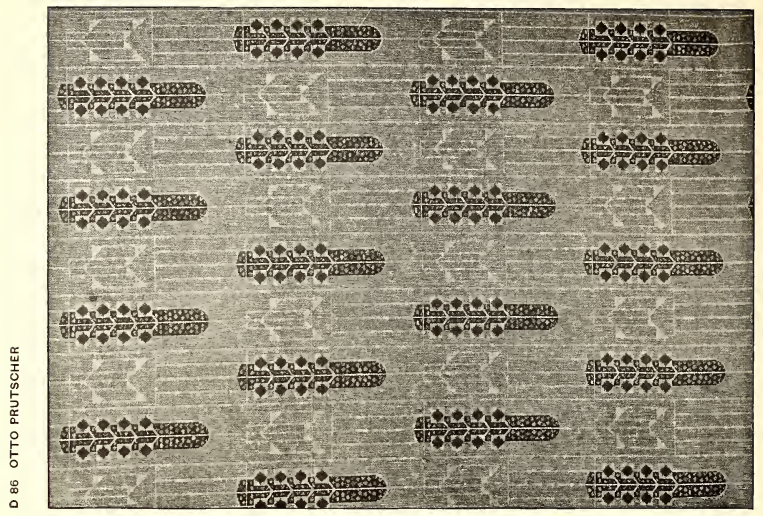

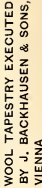

8

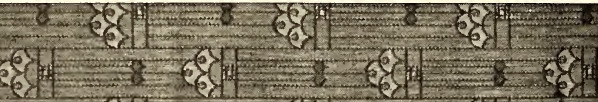

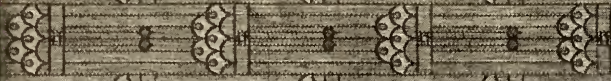

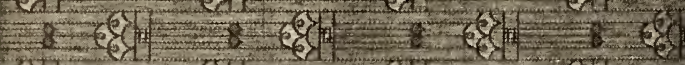

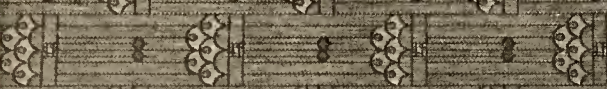

亩新

西

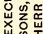

एक्षे

点和

年

更

z

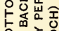

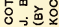




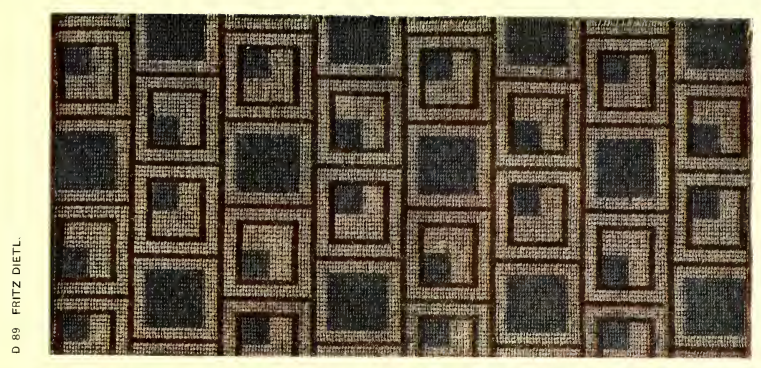

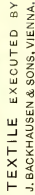

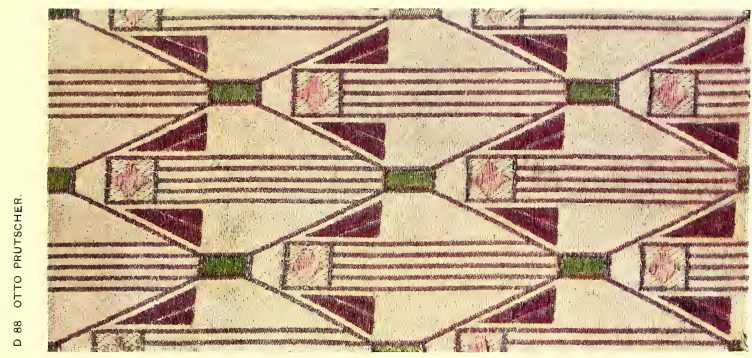

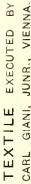

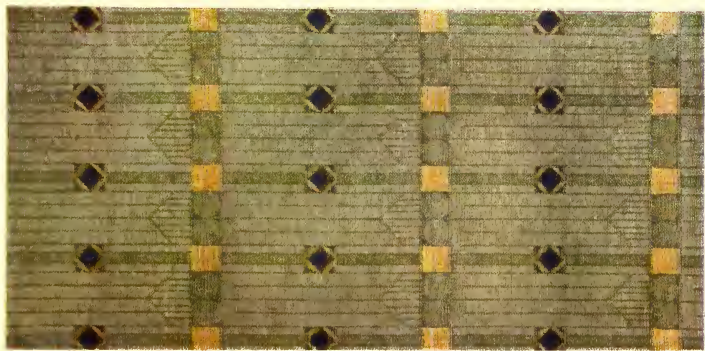

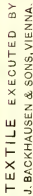





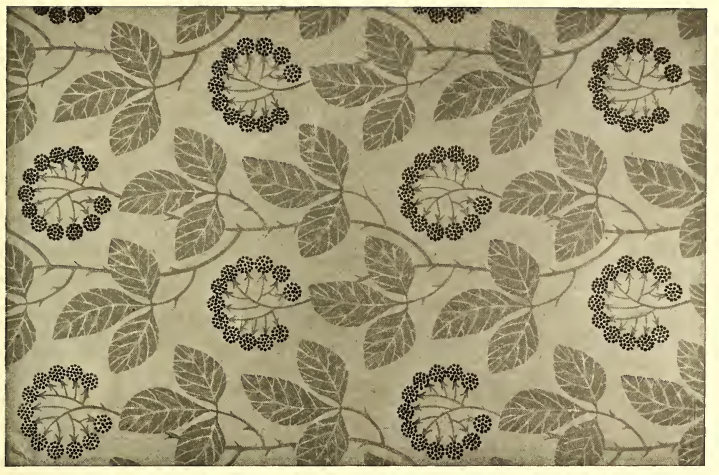

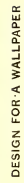

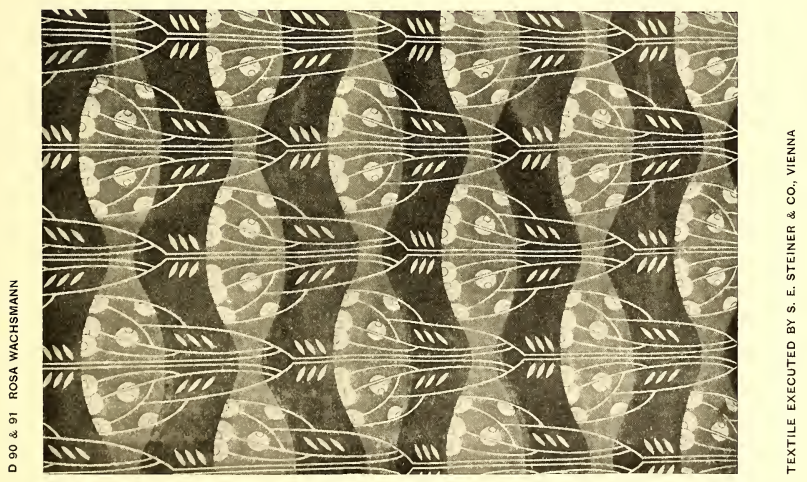



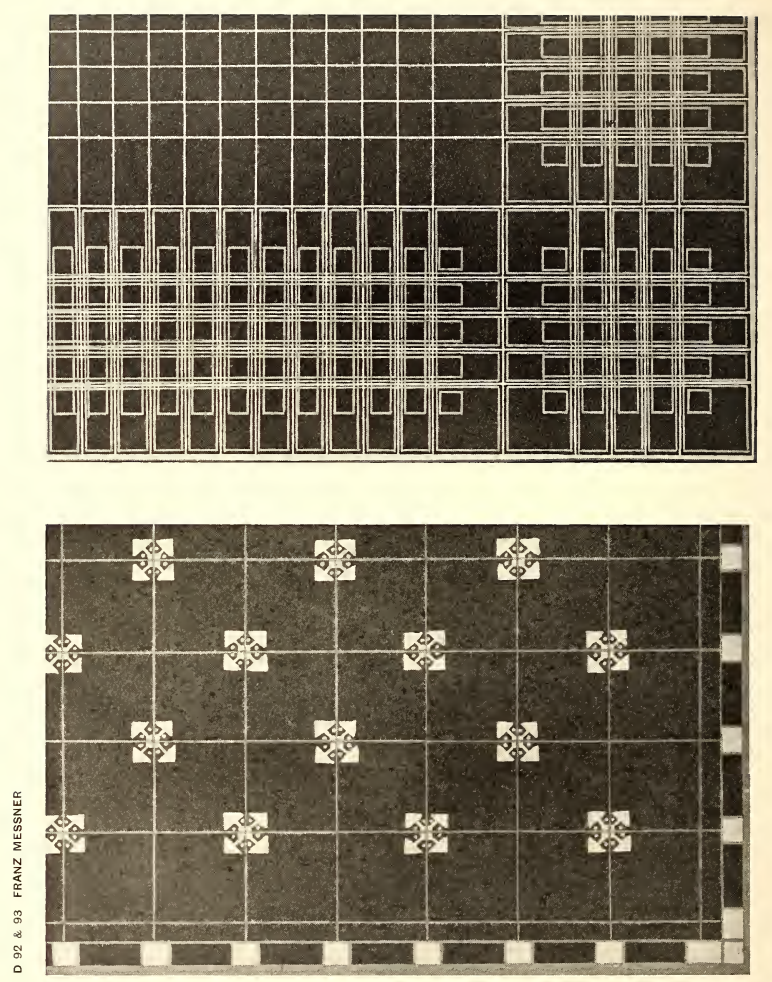


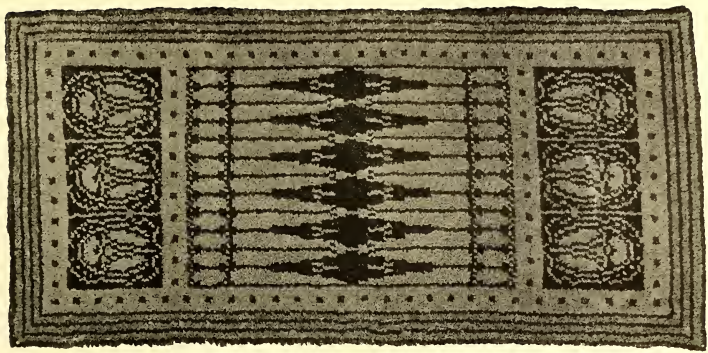

๖े

으

氙

岸忌

is

늘

뭉

of

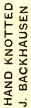
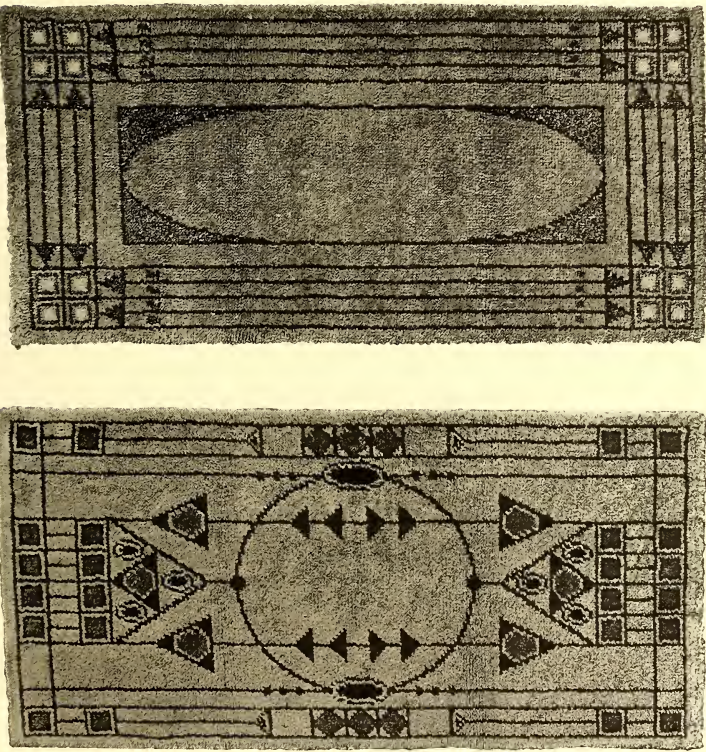
D $97 \& 98$ BETTY STOOSS
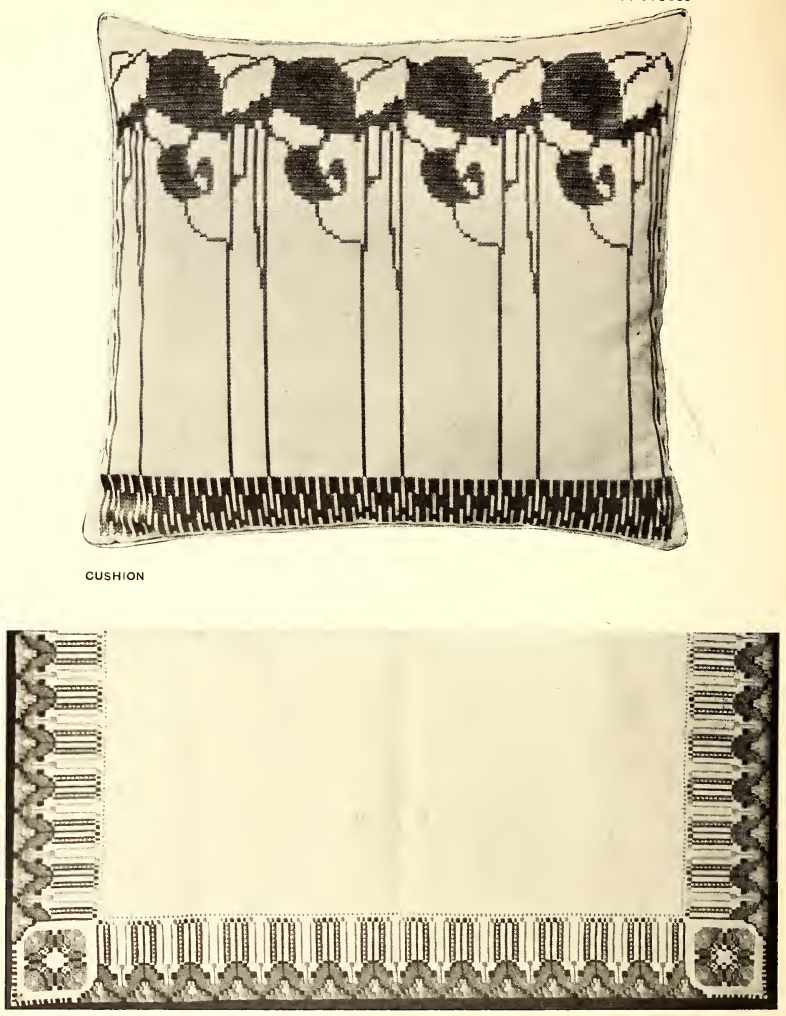

PORTION OF A TABLE COVER 




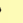







0 
